Prepared in cooperation with the Broward County Environmental Planning and Resilience Division

\title{
Potential for Increased Inundation in Flood-Prone Regions of Southeast Florida in Response to Climate and Sea-Level Changes in Broward County, Florida, 2060-69
}

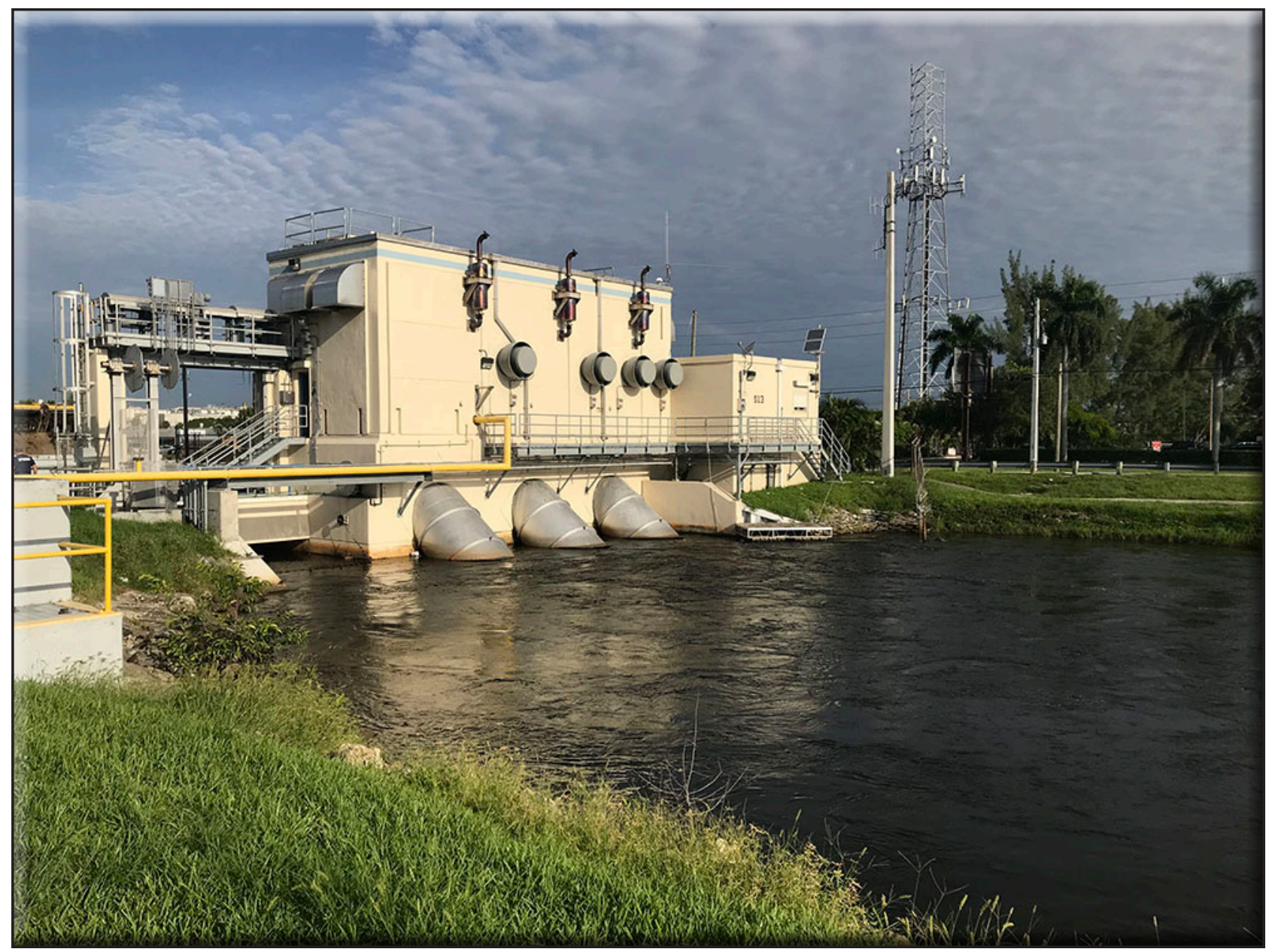

Scientific Investigations Report 2018-5125 
Cover. Photograph showing S-13 structure. Photograph by Jeremy D. Decker, U.S. Geological Survey. 


\section{Potential for Increased Inundation in Flood-Prone Regions of Southeast Florida in Response to Climate and Sea-Level Changes in Broward County, Florida, 2060-69}

By Jeremy D. Decker, Joseph D. Hughes, and Eric D. Swain

Prepared in cooperation with the Broward County Environmental Planning and Resilience Division

Scientific Investigations Report 2018-5125 


\title{
U.S. Department of the Interior \\ DAVID BERNHARDT, Acting Secretary
}

\author{
U.S. Geological Survey \\ James F. Reilly II, Director
}

U.S. Geological Survey, Reston, Virginia: 2019

For more information on the USGS - the Federal source for science about the Earth, its natural and living resources, natural hazards, and the environment-visit https://www.usgs.gov or call 1-888-ASK-USGS.

For an overview of USGS information products, including maps, imagery, and publications,

visit https://store.usgs.gov.

Any use of trade, firm, or product names is for descriptive purposes only and does not imply endorsement by the U.S. Government.

Although this information product, for the most part, is in the public domain, it also may contain copyrighted materials as noted in the text. Permission to reproduce copyrighted items must be secured from the copyright owner.

Suggested citation:

Decker, J.D., Hughes, J.D., and Swain, E.D., 2019, Potential for increased inundation in flood-prone regions of southeast Florida in response to climate and sea-level changes in Broward County, Florida, 2060-69: U.S. Geological Survey Scientific Investigations Report 2018-5125, 106 p., https://doi.org/10.3133/sir20185125.

ISSN 2328-0328 (online) 


\section{Contents}

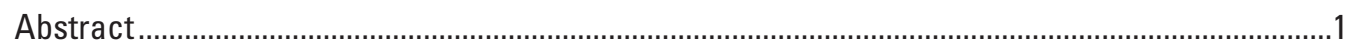

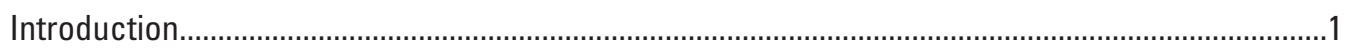

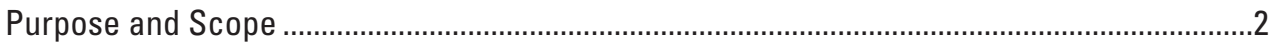

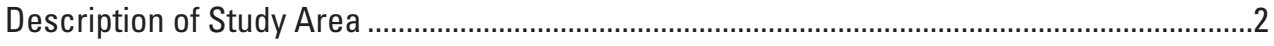

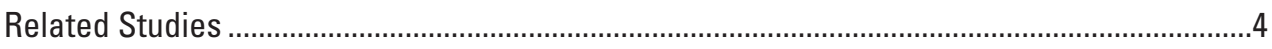

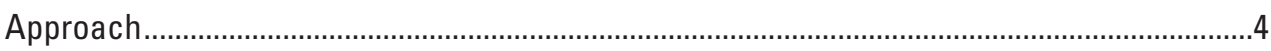

Simulation of the Hydrologic System for Historical Conditions During 1990-99...............................

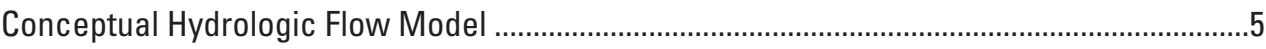

Precipitation and Evapotranspiration..........................................................................

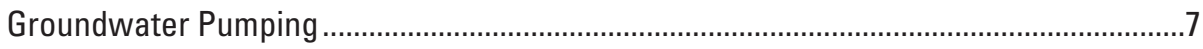

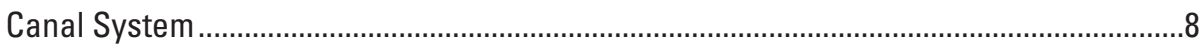

Regional Groundwater Flow ........................................................................................

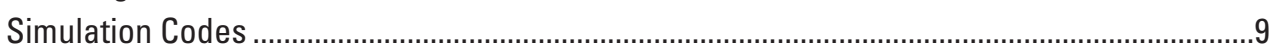

Model Fit to Historical Conditions .........................................................................................10

Simulated Groundwater Levels Within the County-Scale Model...................................11

Simulated Groundwater Levels Within the Local-Scale Model......................................11

Simulated Stages and Flows at Surface-Water Control Structures Within the County-Scale Model ........................................................................................11

Simulated Stages and Flows at Surface-Water Control Structures Within the

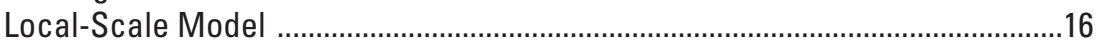

Summary of Model Fit to Historical Conditions ............................................................16

Effects of Climate Changes and Sea-Level Rise on Groundwater Levels, Canal Stages, and Flows at Coastal Structures......................................................................................17

Simulation of Climate Conditions During 1990-99 and 2060-69 ...........................................19

Simulation of the Hydrologic System for Future Climate and Sea-Level Conditions

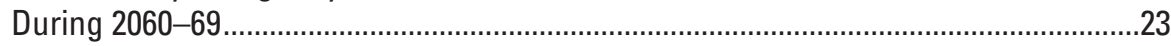

County-Scale Model Scenario Results ......................................................................23

Comparison of CCSM and HadCM3 Base-Case Scenarios to the Historical

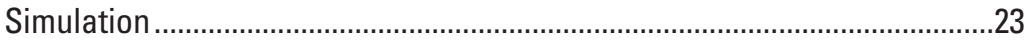

Comparison of Sea-Level Rise and Wetter or Drier Future Scenarios With

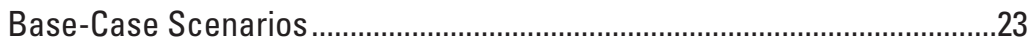

Local-Scale Model Scenario Results .........................................................................

Comparison of Base-Case Climate Scenarios to the Historical Simulation ............34

Comparison of Sea-Level Rise and Wetter or Drier Future Scenarios With

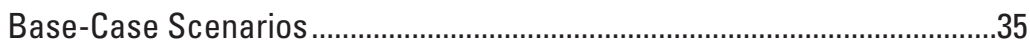

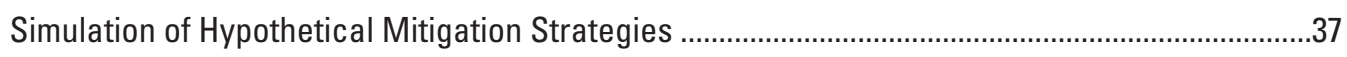

Adapting Pumping Operations at S-13 to Maintain Upstream Stages ..................................38

Pumping Groundwater to Reduce Potential for Inundation ....................................................4

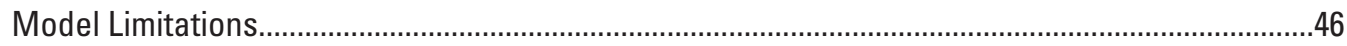

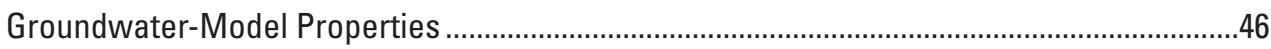

Western Groundwater Head Boundaries ............................................................................... 47

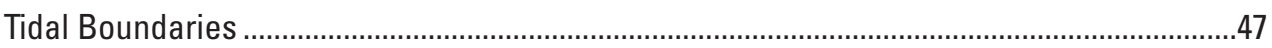

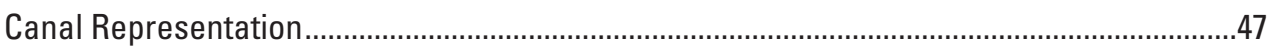

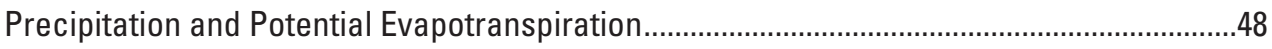

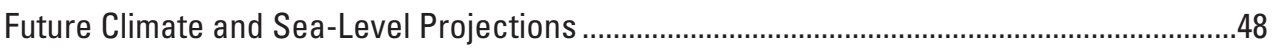

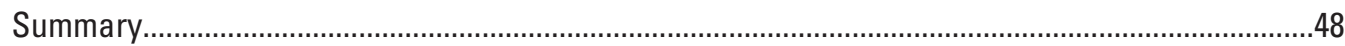




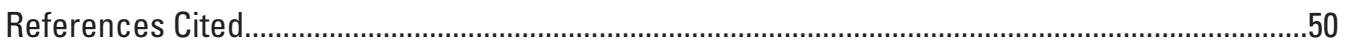

Appendix 1. Simulated Groundwater Response to Individual Precipitation Events .........................54

Appendix 2. Numerical Model Construction .....................................................................................6

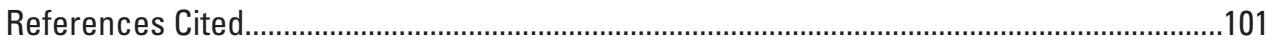

Appendix 3. Sensitivity Testing of Numerical Models ................................................................102

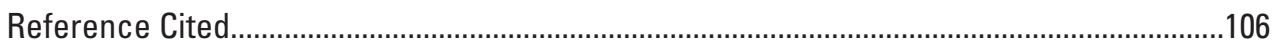

\section{Figures}

1. Map showing location of the study area, Broward County, Florida.

2. Map showing county-scale model area and local-scale model boundaries, Broward County, Florida ............................................................................................. 6

3. Map showing local-scale model area, Broward County, Florida ......................................

4. Graph showing averaged annual precipitation and potential evapotranspiration for the county-scale model area.

5. Graph showing total groundwater-pumping rate in the county-scale simulated area for all simulations

6. Hydrograph showing groundwater levels in Water Conservation Areas and tidal stage during the study period 1990-99. .9

7. Graph showing projected sea-level rise for the 21st century 9

8. Map showing groundwater-level observation locations and transects 12

9. Hydrographs showing simulated and measured groundwater levels for county-scale model transects 1 and 2 during 1990-99

10. Hydrographs showing simulated and measured groundwater levels for county-scale model transects 3, 4, and 5 during 1990-99

11. Hydrographs showing simulated and measured groundwater levels for three observation locations within the local-scale model during 1990-99

12. Hydrographs showing simulated and measured upstream stage and flow at primary active structures G-54 and S-33 during 1990-99 for the county-scale model

13. Hydrographs showing simulated and measured upstream stage and flow at primary active structure S-13 during 1990-99 for the county-scale model

14. Hydrographs showing simulated and measured upstream stage and flow at primary active structure S-9 during 1990-99 for the county-scale model 18

15. Hydrographs showing simulated and measured headwater stage and flow at structures G-54 and S-13 for the local-scale model during 1990-99. 19

16. Graphs showing mean rainfall, in inches, for the county-scale model area.... .20

17. Graph showing cumulative difference in rainfall between the Community Climate System Model climate simulation during 2060-69 and the CCSM climate simulation during 1990-99, and between the Hadley Centre Coupled Model version 3 climate simulation during 2060-69 and the HadCM3 climate simulation during 1990-99, averaged spatially for the county-scale model area

18. Graphs showing mean potential evapotranspiration, in inches, for the county-scale model area.

19. Profiles showing west-east continuous transect of average wet-season groundwater levels for base-case and wetter and drier future sea-level rise scenarios for 2060-69 
20. Hydrographs showing structure $\mathbf{S}-\mathbf{1 3}$ spillway flow for low, intermediate, and high sea-level rise scenarios, and pump flow for the high sea-level rise scenarios for $1990-99$ or $2060-69$.

21. Hydrographs showing upstream stage at structure $S-13$ for low, intermediate, and high sea-level rise and wetter and drier future climate scenarios for 1990-99 or 2060-69.

22. Hydrographs showing upstream stage at primary structures $\mathrm{G}-54, \mathrm{~S}-33$, and S-9 for high sea-level rise and wetter and drier future climate scenarios for 1990-99 or 2060-69.

23. Maps showing percentage of sea-level rise reflected in increased average wet-season groundwater levels for low sea-level rise, intermediate sea-level rise, and high sea-level rise, for wetter future climate scenarios within the county-scale model.

24. Maps showing percentage of sea-level rise reflected in increased average wet-season groundwater levels for low sea-level rise, intermediate sea-level rise, and high sea-level rise, for drier future climate scenarios within the county-scale model.

25. Maps showing average wet-season groundwater levels within the county-scale model for Community Climate Systems Model base case; wetter future, high sea-level rise; and drier future, high sea-level rise, future scenarios.

26. Maps showing average wet-season depth to groundwater for base-case and the wetter future high sea-level rise scenarios within the county-scale model.

27. Hydrographs showing simulated upstream stage at the G-54 and S-13 structures for future climate and sea-level rise scenarios for the local-scale model for 1990-99 or 2060-69.

28. Hydrographs showing spillway and pump flow for structure $S-13$ for wetter future and drier future climate and sea-level rise scenarios for the local-scale model for 1990-99 or 2060-69.

29. Maps showing average wet-season groundwater-level increases in the local-scale model for wetter future low, intermediate, and high sea-level rise scenarios.

30. Maps showing average wet-season groundwater-level increases in the local-scale model for drier future low, intermediate, and high sea-level rise scenarios.

31. Maps showing average wet-season groundwater level for base-case and high sea-level rise, wetter, and drier future climate scenarios for the local-scale area.....

32. Maps showing average wet-season depth to groundwater in the local-scale model for wetter future low, intermediate, and high sea-level rise scenarios.

33. Hydrograph showing upstream stage at structure $S-13$ for wetter and drier high sea-level rise scenarios with original and altered $S-13$ pump operations for 1990-99 or 2060-69.

34. Map showing difference in average wet-season groundwater levels between original and altered S-13 pump operations for the wetter future high sea-level rise scenario...

35. Map showing Areas 1 and 2 for wetter future pumped adaptation strategy simulation.

36. Graphs showing monthly averaged groundwater being removed from Area 1 and Area 2 during drainage scenarios with drainage elevations set to levels zero, 1 foot, and 2 feet above base-case scenario wet-season averages within each cell. 


\section{Tables}

1. County-scale and local-scale model comparison.

2. Fit statistics for groundwater levels of 14 selected well locations for historical county-scale model simulation

3. Fit statistics for groundwater levels at three monitoring locations and upstream stage and flow through primary active control structures for historical

local-scale model simulation.

4. Fit statistics for upstream stage and flow through primary active control structures for historical county-scale model simulation

5. Project modeling scenarios incorporating sea-level rise and climate change predictions

6. Groundwater levels and primary structure flows for the historical simulation and differences in groundwater levels and primary structure flows between Community Climate System Model and Hadley Centre Coupled Model version 3 Base-Case scenarios and the historical simulation at groundwater-well locations shown in figure 8 and surface-water structures shown in figure 2

7. Community Climate System Model Base-Case groundwater levels and primary structure flows and mean differences in groundwater levels and primary structure flows between base-case and wetter future sea-level rise simulations for the county-scale model

8. Hadley Centre Coupled Model version 3 Base-Case groundwater levels and primary structure flows and mean differences in groundwater levels and primary structure flows between base-case and drier future sea-level rise simulations for the county-scale model.....

9. Groundwater levels and primary structure flow and changes for historical and base-case Community Climate System Model and Hadley Centre Coupled Model version 3 simulations for the local-scale model

10. Simulated groundwater levels and primary structure flows and mean differences in groundwater levels and primary structure flows for climate and sea-level rise scenarios using the local-scale model. 


\section{Conversion Factors}

U.S. customary units to International System of Units

\begin{tabular}{|c|c|c|}
\hline Multiply & By & To obtain \\
\hline \multicolumn{3}{|c|}{ Length } \\
\hline inch (in.) & 2.54 & centimeter $(\mathrm{cm})$ \\
\hline inch (in.) & 25.4 & millimeter $(\mathrm{mm})$ \\
\hline foot $(\mathrm{ft})$ & 0.3048 & meter $(\mathrm{m})$ \\
\hline mile (mi) & 1.609 & kilometer (km) \\
\hline \multicolumn{3}{|c|}{ Area } \\
\hline square mile $\left(\mathrm{mi}^{2}\right)$ & 2.590 & square kilometer $\left(\mathrm{km}^{2}\right)$ \\
\hline \multicolumn{3}{|c|}{ Flow rate } \\
\hline million gallons per day (Mgal/d) & 0.04381 & cubic meter per second $\left(\mathrm{m}^{3} / \mathrm{s}\right)$ \\
\hline cubic foot per second $\left(\mathrm{ft}^{3} / \mathrm{s}\right)$ & 0.02832 & cubic meter per second $\left(\mathrm{m}^{3} / \mathrm{s}\right)$ \\
\hline inch per year (in/yr) & 25.4 & millimeter per year (mm/yr) \\
\hline \multicolumn{3}{|c|}{ Hydraulic conductivity } \\
\hline inch per hour (in/h) & 2.54 & centimeter per hour $(\mathrm{cm} / \mathrm{h})$ \\
\hline foot per day (ft/d) & 0.3048 & meter per day $(\mathrm{m} / \mathrm{d})$ \\
\hline \multicolumn{3}{|c|}{ Conductance } \\
\hline square foot per day $\left(\mathrm{ft}^{2} / \mathrm{d}\right)$ & 0.09290 & square meter per day $\left(\mathrm{m}^{2} / \mathrm{d}\right)$ \\
\hline
\end{tabular}

Temperature in degrees Celsius $\left({ }^{\circ} \mathrm{C}\right)$ may be converted to degrees Fahrenheit $\left({ }^{\circ} \mathrm{F}\right)$ as ${ }^{\circ} \mathrm{F}=\left(1.8 \times{ }^{\circ} \mathrm{C}\right)+32$.

Temperature in degrees Fahrenheit $\left({ }^{\circ} \mathrm{F}\right)$ may be converted to degrees Celsius $\left({ }^{\circ} \mathrm{C}\right)$ as ${ }^{\circ} \mathrm{C}=\left({ }^{\circ} \mathrm{F}-32\right) / 1.8$.

\section{Datum}

Vertical coordinate information is referenced to the North American Vertical Datum of 1988 (NAVD 88).

Horizontal coordinate information is referenced to the North American Datum of 1983 (NAD 83).

Elevation, as used in this report, refers to distance above the vertical datum. 


\section{Abbreviations}

AR4

BAS6

CCSM

COAPS

DRN

EDEN

ET

EVT

GCM

GFDL

GHB

HadCM3

HPM

IPCC

LECsR

lidar

LPF

MD

NOAA

NRC

PEST

PEV

$\mathrm{RCH}$

RIV

RMSD

SWR1

URO

USACE

USGS

WCA

WEL
Intergovernmental Panel on Climate Change Fourth Assessment Report

MODFLOW Basic package

Community Climate System Model

Center for Ocean-Atmospheric Prediction Studies

MODFLOW Drain package

Everglades Depth Estimation Network

evapotranspiration

MODFLOW Evapotranspiration package

global circulation model

Geophysical Fluid Dynamics Laboratory

MODFLOW General-Head Boundary package

Hadley Centre Coupled Model version 3

Hydrologic Process Module

Intergovernmental Panel on Climate Change

Lower East Coast sub-Regional Model

light detection and ranging

MODFLOW Layer-Property Flow package

mean difference

National Oceanic and Atmospheric Administration

National Research Council

parameter estimation

percent explained variance

MODFLOW Recharge package

MODFLOW River package

root-mean-square difference

MODFLOW Surface-Water Routing process

MODFLOW Urban Runoff process

U.S. Army Corps of Engineers

U.S. Geological Survey

Water Conservation Area

MODFLOW Well package 


\title{
Potential for Increased Inundation in Flood-Prone Regions of Southeast Florida in Response to Climate and Sea-Level Changes in Broward County, Florida, 2060-69
}

\author{
By Jeremy D. Decker, Joseph D. Hughes, and Eric D. Swain
}

\section{Abstract}

The U.S. Geological Survey, in cooperation with Broward County Environmental Planning and Resilience Division, has developed county-scale and local-scale groundwater/surface-water models to study the potential for increased inundation and flooding in eastern Broward County that are due to changes in future climate and sea-level rise. These models were constructed by using MODFLOW 2005, with the surface-water system represented by using the Surface-Water Routing process and a new Urban Runoff process. The local-scale model allowed the use of finer grid resolution in a selected area of the county, whereas the county-scale model provided boundary conditions for the local-scale model and insight into the hydrologic behavior of the larger system. The aquifer layering, properties, and boundaries relied heavily on a previous three-dimensional variable-density solute-transport model of the same area developed by the U.S. Geological Survey. The surface-water system within these new models actively simulates a part of the extensive canal network by using level-pool routing and active structure operations within the Surface-Water Routing process. These models were used to simulate a historical base-case period (1990-99) by using measured data and regional climate model rainfall and potential evapotranspiration output. The simulated flow and water-level results generally captured the behavior of the hydrologic system. A future period (2060-69) was simulated by using regional climate model rainfall and potential evapotranspiration output representing a wetter and drier future and low, intermediate, and high sea-level rise projections. The results were used to evaluate the potential effects on the surface-water drainage system, coastal-structure operation, and wet-season groundwater levels.

Future period simulations using the county-scale model indicate that (1) the effects of the changing climate and sea level are much more evident in eastern and coastal areas of Broward County compared to western areas, with increases in groundwater level nearly equivalent to sea-level rise; (2) coastal groundwater-level increases are distributed farther inland in the wetter future scenarios than in the drier future scenarios; (3) water levels at the westernmost groundwater station locations exhibited little change caused by sea-level rise and showed more dependence on changes in precipitation; (4) there was a reduced west-to-east groundwater gradient with increasing sea-level rise; and (5) increased downstream tidal stage at the $\mathrm{S}-13$ structure resulted in increased reliance on the pump to control upstream inland canal stages. Future simulations using the local-scale model indicate similar behavior as seen in the county-scale model: (1) the coastal areas exhibited the largest impacts in groundwater levels in the future scenarios; (2) the westernmost, interior areas exhibited little change during the future scenarios; and (3) there was an increased reliance on the pump at the S-13 coastal structure but to a lesser extent than indicated in the county-scale model because of the reduced temporal scale of the local-scale model.

Possible adaptation and mitigation strategies were simulated to evaluate the county-scale and local-scale models' ability to simulate hydrologic changes. Alterations to $\mathrm{S}-13$ pump operations within the county-scale model were tested, and results indicate a reduced effect of sea-level rise inland of the control structure, but the affected area is spatially limited. The concept of using pumps to reduce the local groundwater levels in two neighborhood-sized areas was tested by using the local-scale model. The MODFLOW 2005 Drain package was used to remove groundwater by using drainage elevations set to zero, 1 foot, and 2 feet above average wet-season groundwater levels. Area 1 was well connected to coastal boundaries, and a high rate of groundwater removal was required, whereas the rate of groundwater removal required was greatly reduced in Area 2, which is less connected to tidal boundaries. Water for these scenarios was assumed to be pumped to tide with no downstream effects.

\section{Introduction}

Southeast Florida is highly susceptible to flooding because of its low topography and porous, highly permeable aquifer. Flood risk may be intensified by climatic variations and sea-level rise. Flood management and mitigation strategies for high-density coastal populations in the region are likely to be complicated by projected changes in sea-level rise and climate change. 
Potential for Increased Inundation in Flood-Prone Regions of Southeast Florida in Response to Climate ...

The potential effects of sea-level rise and climate change have become a primary concern for Broward County, Fla., as well as for neighboring communities. The National Oceanic and Atmospheric Administration (NOAA) reports a historical mean sea-level rise for Key West, Fla., of 9 inches (in.) based on monthly mean sea-level data from 1913 to 2013. The unified sea-level rise projections for southeast Florida adopted by the Southeast Florida Regional Climate Change Compact predict an accelerated rate of sea-level rise producing 3-7 in. of additional rise by 2030 and 9-24 in. of rise by 2060 (Southeast Florida Regional Climate Change Compact Technical Ad Hoc Work Group, 2011). Higher tidal stages may result in reduced capacities at the gravity-controlled coastal structures, limiting their abilities to drain inland canals. Additionally, sea-level rise can increase regional groundwater levels, resulting in reduced coastward hydraulic gradients and available groundwater storage and increasing the likelihood and duration of inundation events within inland neighborhoods.

Changes in precipitation amounts that are due to climate change can also increase the vulnerability of southeast Florida's coastal and inland neighborhoods to flooding. More intense rainfall events coupled with reduced drainage capacity and soil storage could lead to increased ponding and inundation. Currently (2018), agreement is poor among the multitude of global and regional climate models concerning projected changes in precipitation amounts; therefore, future planning for flood management and mitigation needs to consider the potential effects of a range of climate model predictions and sea-level rise trends.

To assess the current infrastructure and assist in the development of possible adaptation and mitigation strategies, the U.S. Geological Survey (USGS), in cooperation with the Broward County Environmental Planning and Resilience Division, has developed test-case models at two spatial scales within Broward County by using MODFLOW 2005 (Harbaugh, 2005) the Surface-Water Routing (SWR1) process (Hughes and others, 2012), and a new method - the Urban Runoff (URO) process. Two MODFLOW-2005-based groundwater-flow models were developed for this study. The MODFLOW 2005 countywide model provided regional simulations and was used to establish the boundary conditions for a finer-scale local model for the central part of the county, including the city of Fort Lauderdale. The local-scale model was used in this study to develop a more detailed spatial and temporal analysis of the hydrologic system and canal response to sea-level rise. These models are used to simulate the effects of sea-level rise and variations of climate on groundwater levels and discharge from drainage canals. The results can then be used to help quantify the effectiveness of proposed management and infrastructure changes for various climate-change and sea-level rise scenarios.

\section{Purpose and Scope}

The purpose of this report is to provide information that can be used to help evaluate the increased potential for risk of inundation for various sea-level rise rates and changes in precipitation patterns attributed to climate change in parts of
Broward County. Information and model output providing insight into the hydrologic behavior within the county can be used by county managers to inform future decision making and long-term (multidecadal) planning. After completion, additional scenarios and management strategies can be tested to further evaluate the system's response to proposed or expected changes.

This report documents the construction, testing, and application of numerical hydrologic models used for the analysis. The study area extends east from the water conservation areas to the Atlantic coastline, and from north-central Broward County into northern Miami-Dade County in the south (fig. 1). Input data from two downscaled climate models were tested and evaluated for two periods: a historical period, 1990-99; and a future period, 2060-69, for which predicted sea-level rise was also applied. With a focus on the potential for landscape inundation in the future, the changes in the potential risk for inundation during precipitation events were quantified based on projected shallower groundwater levels and the resulting decreased storage capacity between the water table and land surface (in the unsaturated zone). This report includes descriptions of the hydrologic system, a conceptual flow model, and model parameter estimation. The results of several sea-level rise and climate-change scenarios are presented herein, as well as some evaluation of possible adaptation strategies. Additionally, the structure, equations, and input requirements of the URO process are documented. The study's associated data release contains the model's executable and required input files, URO input instructions and description, as well as post-processing executables that can be used to reproduce simulation results (Decker, 2018).

\section{Description of Study Area}

Broward County has a total land area of 1,225 square miles $\left(\mathrm{mi}^{2}\right)$ and is situated on the southeast coast of Florida (fig. 1). As of 2017, Broward County had a population of 1.9 million, making it the second-most populated county in Florida with approximately 9 percent of the State population (U.S. Census Bureau, 2018). The highly urbanized eastern part comprises approximately one-third of the county, and the remaining undeveloped western part encompasses much of the water conservation areas (WCAs) managed by the South Florida Water Management District (Broward County, 2009).

The majority of Broward County is low and flat, with most land-surface elevations between 2 and 10 feet (ft) above the North American Vertical Datum of 1988 (NAVD 88). The highest natural elevations within the county are approximately $30 \mathrm{ft}$ above NAVD 88 along the Pine Island Ridge in the city of Davie (Broward County, 2009). The Biscayne aquifer in Broward County is shallow and composed of highly transmissive limestone. The groundwater and surface-water systems are closely connected. The area has distinct wet and dry seasons with an average annual rainfall between 45 to 60 in., with three-fourths of the rain falling between May and November (Broward County, 2009). Year-to-year variability can be high with periodic dry and wet years. 


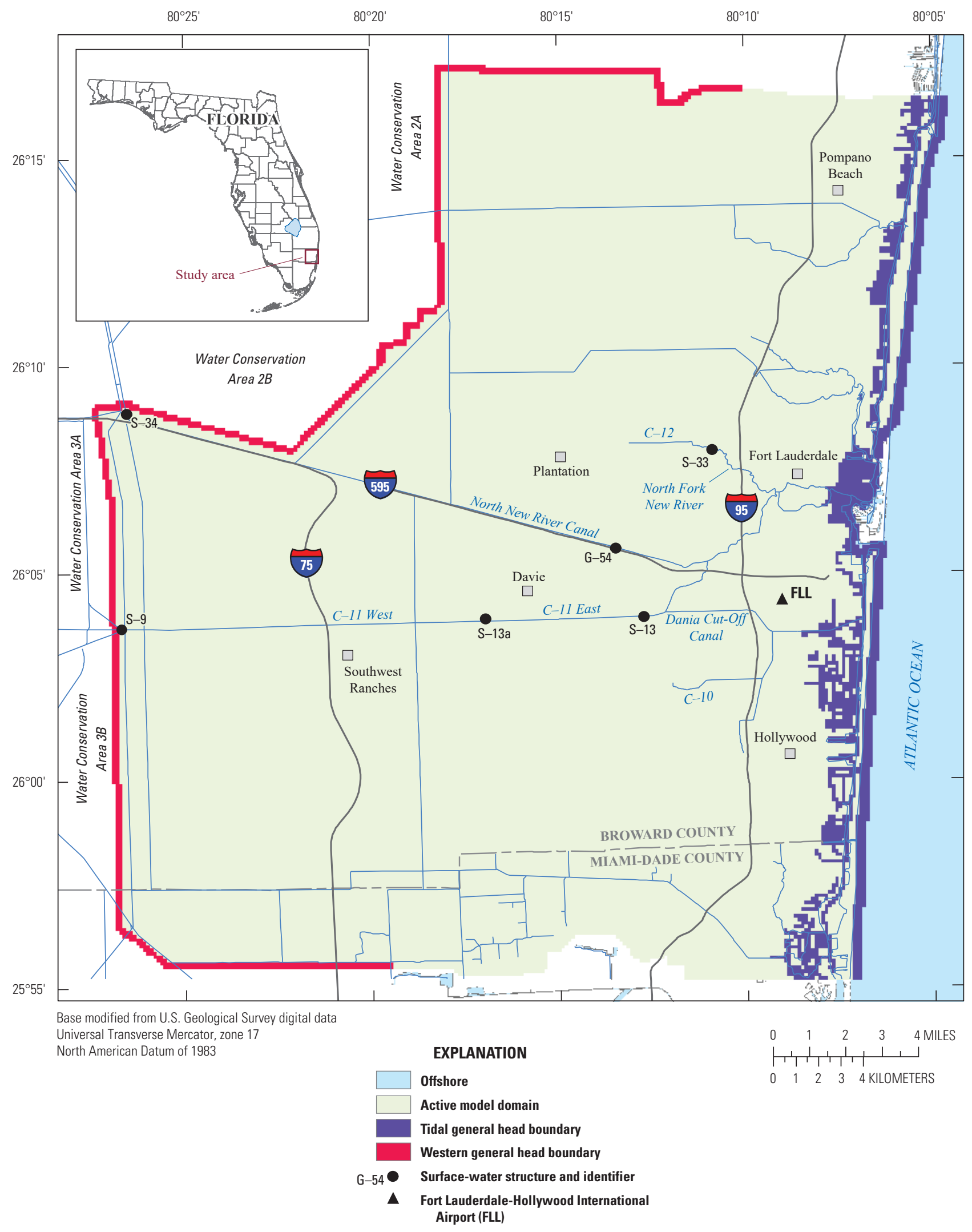

Figure 1. Location of the study area, Broward County, Florida. 
Potential for Increased Inundation in Flood-Prone Regions of Southeast Florida in Response to Climate ...

The existing surface-water management system is used to control groundwater levels and is designed and operated to accomplish several objectives. The system is used to route excess water to the WCAs and to the coast to prevent flooding during the wet season; it is used to route water from the conservation areas to the urban area to recharge the groundwater system to meet supply demands during the dry season; and the system can provide environmental flows when required. The current drainage system includes 1,700 miles of canals, gravity control structures, and pumps (Broward County, 2009). Despite the complexities and capabilities of the system, several areas within Broward County are prone to flooding. In particular, low-lying coastal areas east of the salinity control structures and poorly drained areas in western Broward County near the WCAs have flooding problems.

\section{Related Studies}

The construction of the hydrologic models described in this report rely heavily on a previous study that involved the development of a variable-density, solute-transport groundwater-flow model of central and southern Broward County, Fla. (Hughes and others, 2016). The model was calibrated to conditions from 1970 to 2012 by using automated parameter estimation (PEST) techniques. The model was then used to simulate historical conditions from 1950 to 2012, evaluate the sensitivity of the salinity distribution in groundwater to sea-level rise and groundwater pumping, and estimate the possible effects on future salinity distribution in the aquifer attributed to changes in groundwater pumping, sea-level rise, and changes to the hydrologic system. The vertical layering used within the model was based on a composite of lithostratigraphic and conceptual hydrogeologic models. The model was calibrated by using the PEST software to estimate model parameters so as to reasonably replicate measured head and salinity values. The software-estimated parameters at discrete pilot-point locations and then the cell-by-cell parameter values were spatially interpolated from these points. A combination of coarse and fine pilot points was used with increased pilot-point coverage near the saltwater/freshwater interface.

The central and southern Broward County model relied upon the input datasets from two other existing groundwater-flow models during model construction: (1) the Lower East Coast sub-Regional Model (LECsR) (Giddings and others, 2006) and (2) a groundwater-flow and surface-water-flow model developed for the urbanized areas within Broward County using the MIKE SHE and MIKE 11 simulators (referred to hereinafter as the "MIKE SHE/MIKE 11 model"; Islam and Dunn, 2006). The LECsR model was composed of smaller subregional flow models and was used to assist with regional water supply issues and the Comprehensive Everglades Restoration Plan. The MIKE SHE/MIKE 11 model was used to aid Broward County in evaluating water management plans and practices.
The SWR1 process of MODFLOW was developed for and first applied to a study area within neighboring Miami-Dade County (Hughes and others, 2016). The groundwater/surface-water model for this area was used to evaluate the movement of the saltwater/freshwater interface in response to changes in groundwater pumpage and sea-level rise. Additionally, the model was used to evaluate changes in canal leakage in the area during these future scenarios. The study concluded that the model effectively represented the interconnectivity between the extensive surface-water and underlying groundwater systems.

There have been several other groundwater models developed for the area or that include parts of the area: (1) Langevin and Zygnerski (2013) developed a model for the northern part of coastal Broward County to evaluate the effects of well-field pumping and sea-level rise on the salinity distribution; (2) a model was developed to simulate the salinity distribution and effects of well-field management for areas near Hallandale Beach (Andersen and others, 1988); and (3) a three-dimensional model was constructed by Guha and Panday (2012) to predict the effect of sea-level rise on the distribution of salinity in southern Broward and northern Miami-Dade Counties.

The development of the methods used to simulate infiltration, recharge, and unsaturated zone storage within the URO process was based on concepts used by the South Florida Management District in the Regional Simulation Model's Hydrologic Process Modules (HPMs) for different land-use types. In one such HPM, infiltration and recharge rates are calculated based on maximum rates and watercontent-dependent relationships. Excess rainfall is routed to adjacent features or stored, which is similar in concept to the URO handling of rainfall, evapotranspiration (ET), and runoff, in which infiltration and recharge rates are water-content dependent and based on maximum rates; however, water can be stored in the unsaturated zone and stored as surface water.

\section{Approach}

Two hydrologic flow models, together henceforth called the inundation models, were created using MODFLOW 2005 and the URO MODFLOW process, developed for this study. The larger of the two models, henceforth called the county-scale model, covers $450 \mathrm{mi}^{2}$ in areal extent and uses a relatively coarse $500-\mathrm{ft}$ grid. The smaller of the two models, henceforth called the local-scale model, lies within the boundaries of the county-scale model, uses a relatively fine 166.7-ft grid resolution, and uses output from the county-scale model as boundary conditions. The local-scale model provides output at a finer grid resolution and incorporates a more detailed representation of the surface-water system.

The county-scale model is a modified version of a SEAWAT-based (Langevin and others, 2008) saltwater-intrusion model developed to simulate the effects of hydrologic changes on the distribution of groundwater salinity within central and southern Broward County (Hughes 
and others, 2016). Changes made to the saltwater-intrusion model for the county- and local-scale models include converting to MODFLOW 2005 from SEAWAT, such that variable-density transport is not simulated. Neglecting the approximate 2.5-percent difference in density between fresh and saltwater reduces computational time with limited impact on model results. The number of hydrogeologic model layers was reduced from 12 vertical layers to 3 vertical layers, thus simplifying the groundwater component of the inundation models. Canal stages and flows were simulated using active level-pool routing in the central part of the county-scale model and in all areas of the local-scale model, as opposed to non-dynamic, specified stage reaches (fig. 2). Additionally, rather than using the MODFLOW 2005 Evapotranspiration (EVT) and Recharge (RCH) packages, the URO process was used to represent ET, precipitation, infiltration, and recharge within the county- and local-scale models. The MODFLOW 2005 stress period length was shortened from monthly to daily periods with hourly URO and groundwater time steps and 15-minute SWR1 time steps. These changes were necessary for increased SWR1 model stability and to increase the temporal resolution of the surface-water output.

The local-scale model extent was chosen to include both a coastal area, which is directly exposed to sea-level rise and an inland area that may experience decreases in groundwater storage and reduced drainage capacities associated with an increase in sea level (fig. 2). Compared to the county-scale model, the temporal and spatial scales were reduced for a more detailed analysis of the hydrologic system (table 1). Groundwater levels predicted from the county-scale model were specified along the local-scale model's perimeter by using head-dependent flow boundaries within MODFLOW (general head boundaries, GHBs) (figs. 2 and 3). The canal network from the county-scale model was supplemented with additional secondary and some tertiary features. All canals within the local-scale model were simulated as level-pool reach groups. Canal inflows and outflows obtained from the county-scale model were added to the local-scale model using specified lateral flows within the SWR1 process. A more refined topography was incorporated into the local-scale model than was used in the county-scale model, derived using light detection and ranging (lidar) data at a spatial discretization of $166.7 \mathrm{ft}$ compared to the $500 \mathrm{ft}$ used in the county-scale model (South Florida Water Management District, 2009). Aquifer properties, including hydraulic conductivity, vertical hydraulic conductivity, specific storage, and porosity were calculated from the county-scale model property fields by using bilinear interpolation. The areal extent of the local-scale model was $61.5 \mathrm{mi}^{2}$.

The inundation models were used to simulate changes in groundwater levels and canal operations that are due to sea-level rise and changes in predicted future precipitation, which could lead to increased inundation and flooding events. The climate model projections were provided by the Center for Ocean-Atmospheric Prediction Studies (COAPS) for a historical period from 1968 to 1999 and a future period from 2038 to 2069 (Stefanova and others, 2012). Output from a regional-scale climate model of the Southeast United
States developed by COAPS was used with three alternative general circulation models providing boundary conditions: the Community Climate System Model (CCSM), the Geophysical Fluid Dynamics Laboratory (GFDL) model, and the Hadley Centre Coupled Model version 3 (HadCM3). The CCSM and HadCM3 model projections showed the most variability and were used for this study. The projections correspond to the Intergovernmental Panel on Climate Change (IPCC) Fourth Assessment Report (AR4) A2 emissions scenario representing a heterogeneous world with continuously increasing world population (IPCC, 2007). The latest 10-year periods of the historical and future projections simulations were used for this study. Predicted sea-level rise input was calculated by using the methods described by the U.S. Army Corps of Engineers (USACE) and the modified National Research Council (NRC) sea-level rise Curves I and III (USACE, 2011). A more conservative scenario was included that used the current linear rate of sea-level rise estimated from historical tidal measurements. These sea-level rise scenarios represent low, intermediate, and high predictions.

Several scenarios were evaluated by using combinations of these sea-level rise and climate-change model inputs, as well as a historical scenario using measured potential ET, rainfall, and observed tidal stage, which were used for model validation. Potential adaptation and mitigation strategies were tested to gauge the model's ability to predict hydrologic alterations, and the results were analyzed. Additionally, groundwater levels within the local-scale model following a historical precipitation event and two future scenario precipitation events were evaluated and are presented in appendix 1.

\section{Simulation of the Hydrologic System for Historical Conditions During 1990-99}

The inundation models were designed to simulate groundwater levels, canal stages, and canal structure flows within the central and southern parts of Broward County. Historical simulation inputs were prepared and run to represent the hydrologic conditions of 1990-99. Details of model construction are provided in appendix 2 . The sensitivity of these models to changes in model parameters were tested (appendix 3). No formal calibration was completed and parameters for the model were derived primarily from existing, calibrated models. The resulting models were then used to simulate base-case and future scenarios by using climate model output and sea-level rise estimates.

\section{Conceptual Hydrologic Flow Model}

Inflows into the study area's surface-water system include precipitation, groundwater discharge within inundated areas, aquifer-to-canal discharge, and canal inflows from the western control structures. Surface-water outflows consist 


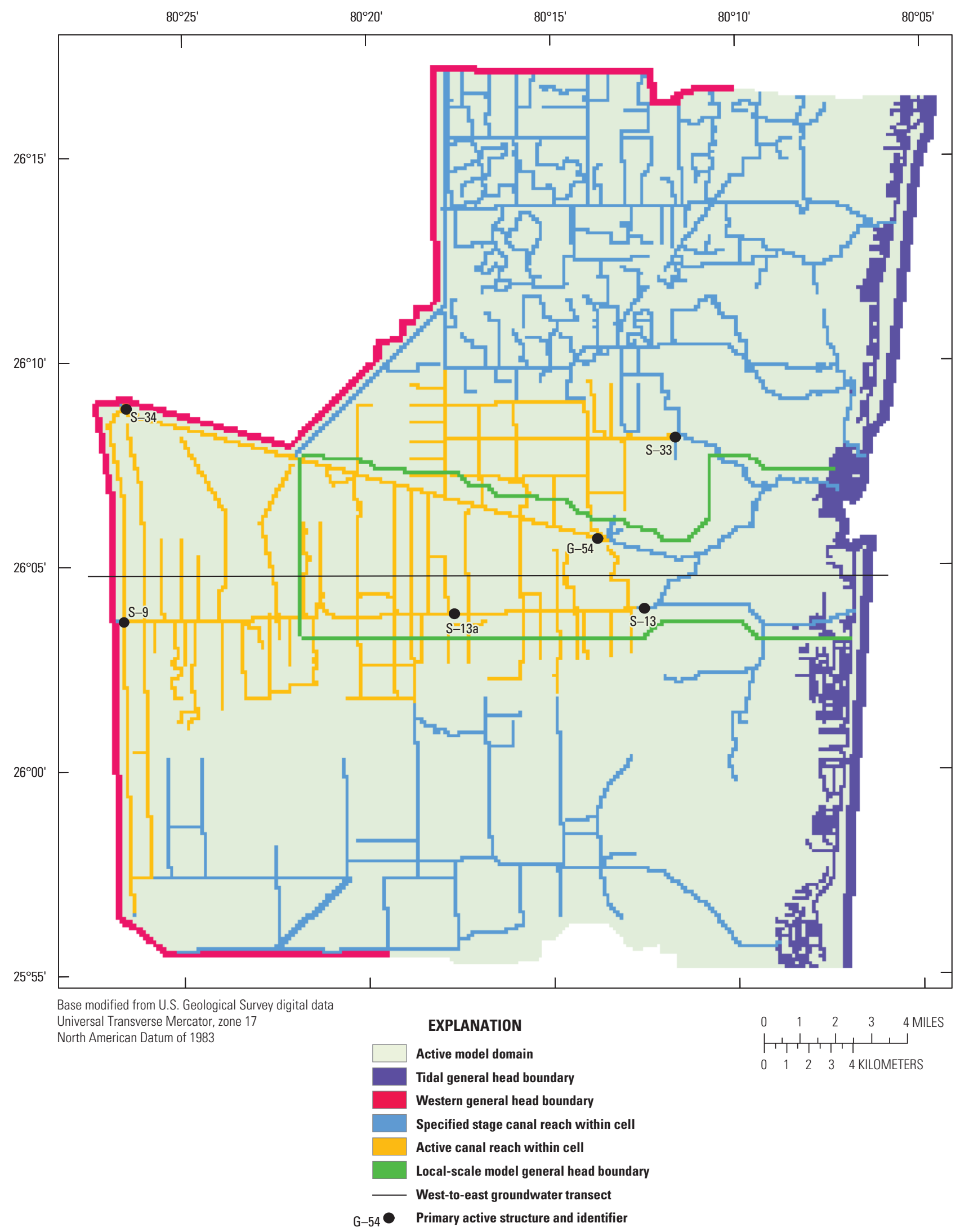

Figure 2. County-scale model area and local-scale model boundaries, Broward County, Florida. 
Table 1. County-scale and local-scale model comparison.

[mi², square mile; ft, foot; SWR1, surface-water routing]

\begin{tabular}{lcc}
\hline & County-scale model & Local-scale model \\
\hline Columns/rows & $501 / 411$ & $531 / 159$ \\
Active spatial extents & $450 \mathrm{mi}^{2}$ & $61.5 \mathrm{mi}^{2}$ \\
Groundwater layers & 3 & 3 \\
Spatial discretization & $500 \mathrm{ft}$ & $166.7 \mathrm{ft}$ \\
MODFLOW stress period/time step & 1 day/1 hour & 1 day/1 hour \\
Canal representation & Active level-pool routing and specified stage & Active level-pool routing \\
SWR1 time step/tidal level update & 15 minutes/1 day & 10 minutes/1 hour \\
Historical/ base-case simulation period & $1 / 1 / 1990-12 / 31 / 1999$ & $1 / 1 / 1990-12 / 31 / 1999$ \\
Future simulation period & $1 / 1 / 2060-12 / 31 / 2069$ & $1 / 1 / 2060-12 / 31 / 2069$ \\
\hline
\end{tabular}
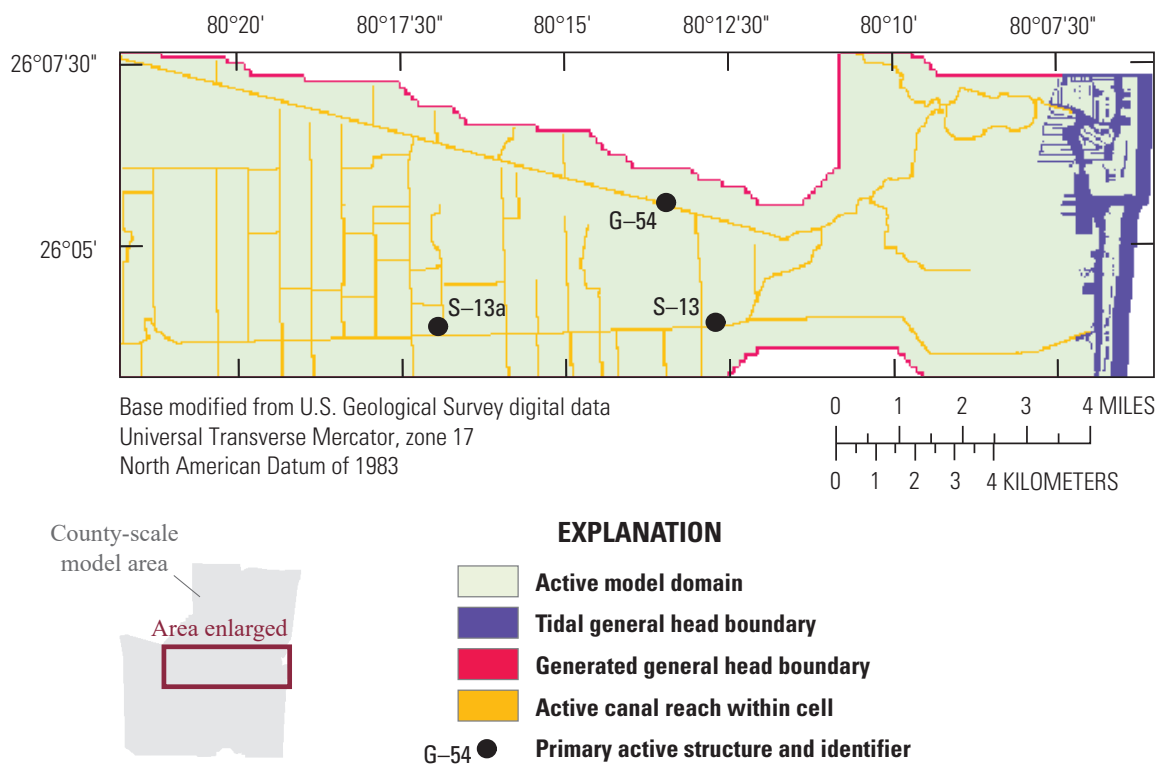

EXPLANATION

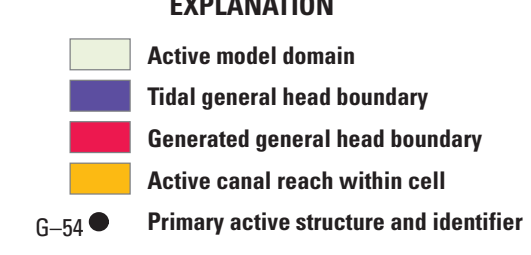

Figure 3. Local-scale model area, Broward County, Florida.

of ET, groundwater recharge, canal-to-aquifer leakage, and canal discharge through the coastal/western control structures. Aquifer inflows include recharge from the unsaturated zone, canal leakage, and boundary influxes from the western interior and the eastern tidal zone. Aquifer outflows consist of groundwater discharge to canals, ET, groundwater pumping, boundary outflows to the western interior, and submarine discharge along the coast.

\section{Precipitation and Evapotranspiration}

A spatially variable rainfall time series was created for the historical simulations using data from 18 measurement locations within the county-scale model area (appendix 2). During the historical study period (January 1, 1990, to December 31, 1999), the average of these rainfall time series varied between 52.6 inches per year (in/yr) and $76.2 \mathrm{in} / \mathrm{yr}$, with an average of
$62.5 \mathrm{in} / \mathrm{yr}$. A spatially uniform potential evapotranspiration rate was created for the historical simulations using data from two measurement locations near the study area (appendix 2). During the historical study period, the average value of this potential ET time series varied between $63.2 \mathrm{in} / \mathrm{yr}$ and $86.9 \mathrm{in} / \mathrm{yr}$, with an average of $73.6 \mathrm{in} / \mathrm{yr}$ (fig. 4).

\section{Groundwater Pumping}

Groundwater is removed from the system as the Biscayne aquifer is the primary water supply for Broward County. The 1990-99 monthly groundwater pumpage values and locations from the pre-existing variable-density model were used for base-case, historical, and future model simulations (fig. 5) (Hughes and others, 2016). The total pumping from the study area has an average removal of 199.5 million gallons per day (Mgal/d) for the historical study period (1990-99). 


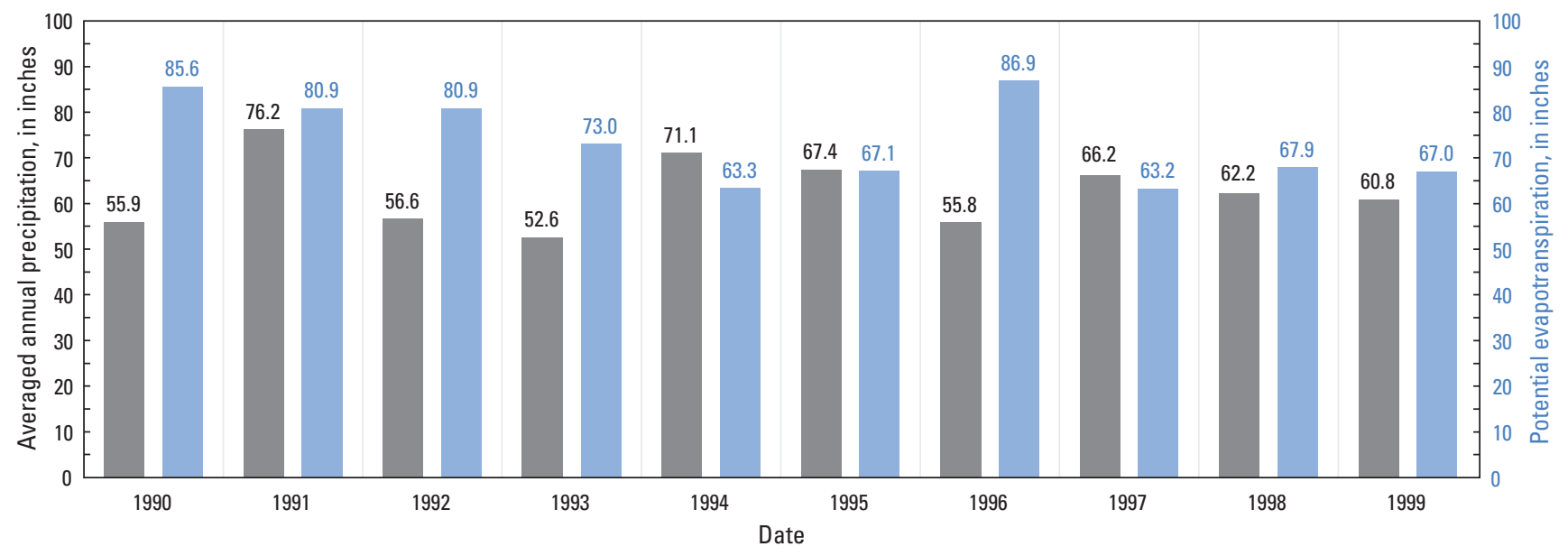

EXPLANATION

Precipitation-Value above bar is averaged annual precipitation, in inches per year (in/yr)

Potential evapotranspiration (ET)—Value above bar is averaged annual potential $\mathrm{ET}$, in in/yr

Figure 4. Averaged annual precipitation and potential evapotranspiration for the county-scale model area.

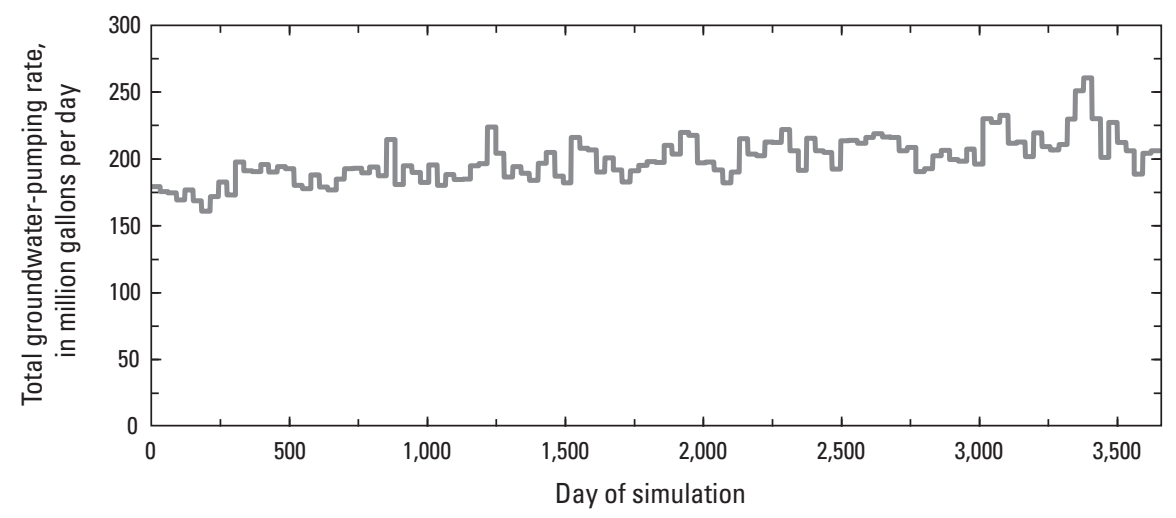

Figure 5. Total groundwater-pumping rate in the county-scale simulated area for all simulations.

\section{Canal System}

The extensive canal system constructed in Broward County is operated to prevent inland flooding while maintaining groundwater levels and salinity gradients to protect well-field water quality. The system has evolved over the course of many decades and now includes primary, secondary, and tertiary canal and drainage features, gravity-fed and pumped structures near the coast, as well as gravity-fed and pumped structures at the western extent of the urban area, which can be used to recharge the system or discharge flows west to the WCAs. Conceptually, leakage from the canal system can recharge the groundwater aquifer when surface-water stages are maintained at higher levels than groundwater levels or can discharge water coastward from the aquifer when groundwater levels are higher than surface-water stages. A recent hydrologic study in adjacent Miami-Dade County indicates that the surface-water system discharges more water from the aquifer than it recharges to the aquifer (Hughes and White, 2014). The directionality of these groundwater/surface-water interactions depend upon seasonal conditions and water management practices.

\section{Regional Groundwater Flow}

The study area is bound to the west by the WCAs, which maintain high groundwater elevations, and to the east by the Atlantic Ocean (fig. 1). Land-surface elevation and groundwater levels are generally higher to the north than to the south, which results in a historical potentiometric surface that generally slopes from the northwest to the southeast. Localized cones of depression, which form around major production-well locations, are superimposed on a low-gradient potentiometric surface (Renken and others, 2005). The northwest-to-southeast groundwater-flow gradient is illustrated by comparing daily measurements from three representative WCA stations with 
tidal stage observations (fig. 6). From north to south, the average daily stage of the WCA sites are $10.98 \mathrm{ft}, 9.23 \mathrm{ft}$, and $6.44 \mathrm{ft}$ above NAVD 88 for sites 2-17 (WCA2), 3-63 (WCA3), and 3-76 (WCA3), respectively. Daily averaged tidal levels during the study period vary between $-2.167 \mathrm{ft}$ and $0.849 \mathrm{ft}$ above NAVD 88 , with an average of $-0.848 \mathrm{ft}$ above NAVD 88 .

Future changes in tidal levels could substantially alter the regional groundwater levels, gradients, and the resulting groundwater/surface-water flows. Sea-level rise projections for the 21 st century, calculated by using methods described by the USACE and the modified NRC sea-level rise Curves I through III, range from 6.77 to 17.05 in. for 2050 and from 20.04 to 58.4 in. for 2100 (USACE, 2011). The 2017 local estimated rate of sea-level rise of 2.24 millimeters per year $(\mathrm{mm} / \mathrm{yr})$ ( $0.088 \mathrm{in} / \mathrm{yr}$ ) projects out to $3.53 \mathrm{in}$. for 2050 and $7.93 \mathrm{in}$. for 2100 (fig. 7).

\section{Simulation Codes}

Both the county- and local-scale models were constructed by using MODFLOW 2005 (Harbaugh, 2005). MODFLOW 2005 is a three-dimensional finite-difference groundwater model based on Darcy's Law and conservation of mass principles that simulates steady-state or transient flow in a confined or unconfined aquifer system. Model applications can include external stresses such as specified fluxes, specified heads, and head-dependent flows. The simulations described in this report include the use of the Basic (BAS6), Layer-Property Flow (LPF), Well (WEL), and the General-Head Boundary (GHB) packages, the SWR1 process and a new process, URO (Harbaugh, 2005; Decker and Hughes, 2013). Required input for the model simulations

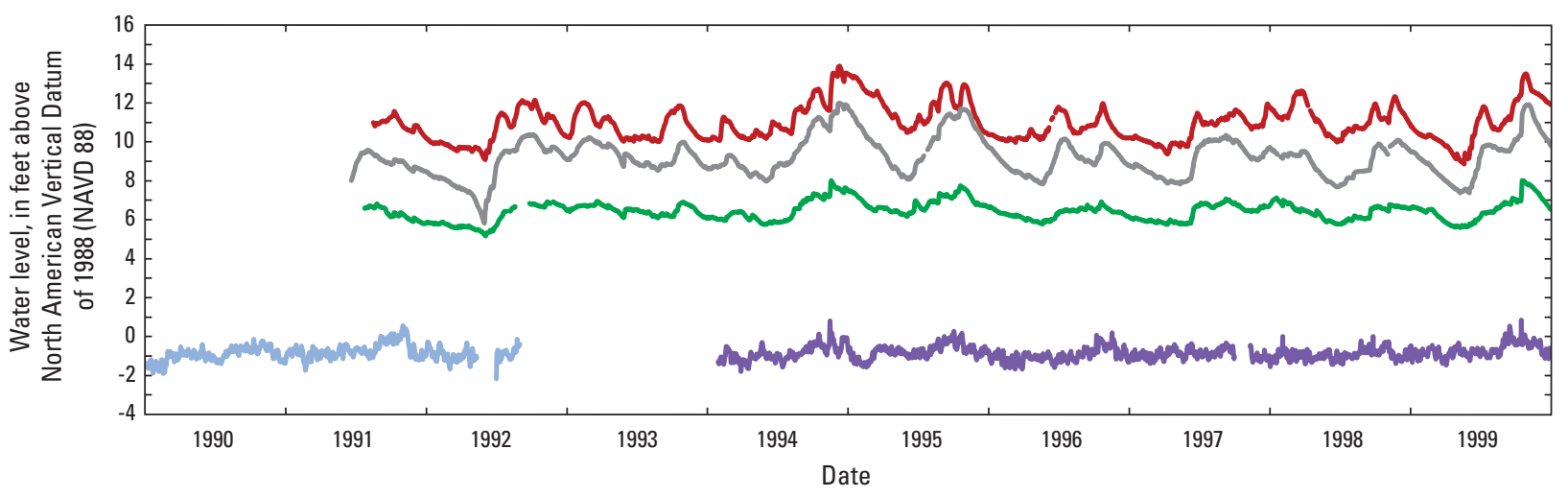

EXPLANATION

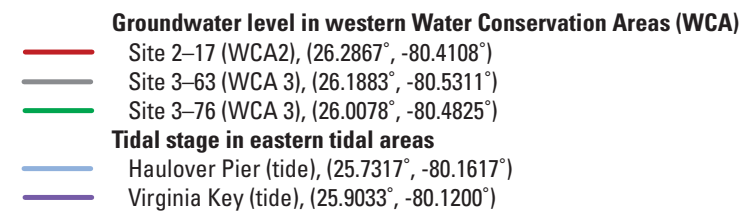

Figure 6. Groundwater levels in Water Conservation Areas and tidal stage during the study period 1990-99. Western groundwater levels include sites 2-17, 3-63, and 3-76. Eastern tidal locations include Haulover Pier and Virginia Key. Location of sites in latitude and longitude included in explanation.

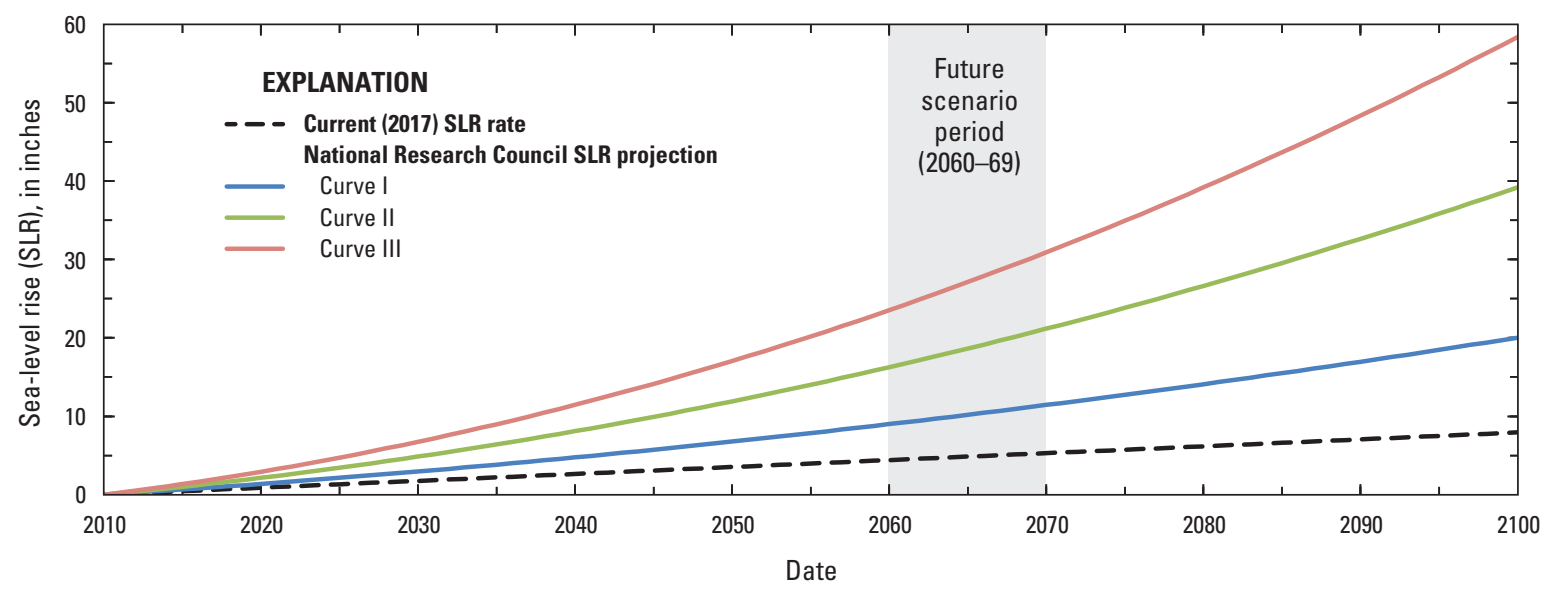

Figure 7. Projected sea-level rise for the 21st century. 
included aquifer layering elevations, vertical and horizontal hydraulic conductivity, specific yield of layer 1, specific storage of all groundwater layers, withdrawal rates at pumping locations within the model area, groundwater levels and conductance values along boundaries, canal locations, canal connectivity, canal cross-sectional information, canal leakance values, water control structure locations and operations or height settings, specified canal flows or specified canal stages at several locations, rainfall rates, potential ET rates, maximum infiltration, and maximum recharge rates.

The SWR1 process (Hughes and others, 2012) simulates surface-water stages and flows and surface-water/groundwater interactions. Surface-water features can be represented as specified stages or actively simulated by using level-pool or diffusive wave routing. The SWR1 process can simulate several water-control structure types and simple structure operations. The SWR1 process is implicitly coupled to MODFLOW 2005.

The MODFLOW 2005 process, URO, was created and used to simulate additional surface-water processes. The URO process can represent two-dimensional overland flow by using a diffusive wave approach, precipitation, ET, infiltration, and recharge. Like the SWR1 process, the URO process is implicitly coupled to MODFLOW 2005 (Decker and Hughes, 2013). The equations and input data used for the URO process are included in appendix 2.

\section{Model Fit to Historical Conditions}

Simulated groundwater levels, canal stages, and structure flows were compared to measured values, and model-fit statistics were calculated to evaluate the ability of county-scale and local-scale models to reproduce historical conditions.

The mean difference (MD), root-mean-square difference (RMSD), and the percent explained variance (PEV) were calculated for simulated and measured values of groundwater level, upstream stage at surface-water control structures, and flow rate through structures at selected observation sites with available continuous monitoring (table 2). The MD describes how evenly the simulated observation values are distributed between greater than or less than measured observation values, where positive values of MD indicate that the simulated values are, overall, greater than measured, and negative values indicate that simulated values are less than measured. The MD was calculated by using the following equation:

$$
M D=\frac{1}{n} \sum_{i=1}^{n}\left(X_{s}^{i}-X_{m}^{i}\right)
$$

where

$\begin{array}{cl}n & \text { is the number of simulated/measured values } \\ X_{s}^{i} & \text { is the } i \text { th simulated value; and } \\ X_{m}^{i} & \text { is the } i \text { th measured value. }\end{array}$

Table 2. Fit statistics for groundwater levels of 14 selected well locations for historical county-scale model simulation.

\begin{tabular}{lccc}
\hline \multicolumn{1}{c}{ Station name } & $\begin{array}{c}\text { Mean } \\
\text { difference } \\
\text { (foot) }\end{array}$ & $\begin{array}{c}\text { Root-mean- } \\
\text { square } \\
\text { difference } \\
\text { (foot) }\end{array}$ & $\begin{array}{c}\text { Explained } \\
\text { variance } \\
\text { (percent) }\end{array}$ \\
\hline G-2031 & 0.567 & 0.733 & 28.8 \\
G-1316 & 0.359 & 0.513 & 59.0 \\
G-853 & -1.605 & 2.141 & 27.2 \\
G-2033 & -0.056 & 0.449 & 24.3 \\
G-2395 & 6.661 & 6.829 & 50.1 \\
G-1220 & -0.206 & 0.459 & 70.7 \\
G-617 & -0.105 & 0.514 & 10.5 \\
G-1221 & 0.265 & 0.639 & 33.7 \\
G-561 & -0.172 & 0.496 & 55.2 \\
G-2034 & -0.055 & 0.536 & 29.8 \\
G-1225 & 0.376 & 0.653 & 67.8 \\
F-291 & -0.637 & 0.804 & 61.6 \\
G-970 & 0.005 & 0.343 & 55.4 \\
G-3571 & 0.045 & 0.617 & 47.1 \\
Mean of all stations & 0.389 & 1.123 & 44.4 \\
Mean excluding & 0.032 & 0.563 & 45.3 \\
G-2395 and & & & \\
G-853 & & & \\
\hline
\end{tabular}

The RMSD indicates the magnitude of the error of simulated values relative to measured values, where a larger value indicates a larger error, and a smaller value indicates a smaller error, and thus relatively closer fit of simulated to measured values of the observations. The RMSD was calculated by using the following equation:

$$
R M S D=\sqrt{\frac{1}{n} \sum_{i=1}^{n}\left(X_{s}^{i}-X_{m}^{i}\right)^{2}}
$$

The PEV indicates how closely the model simulates the variance represented in the measured observation values, where the closer the value is to 1.0, the more similar are the variances of simulated and measured values. The PEV was calculated by using the following equation:

$$
P E V=1-\frac{\sum_{i=1}^{n}\left[\left(X_{s}^{i}-\bar{X}_{s}\right)-\left(X_{m}^{i}-\bar{X}_{m}\right)\right]^{2}}{\sum_{i=1}^{n}\left(X_{m}^{i}-\bar{X}_{m}\right)^{2}}
$$

where

$$
\begin{array}{ll}
\bar{X}_{s} & \text { is the mean simulated value, and } \\
\bar{X}_{m} & \text { is the mean measured value. }
\end{array}
$$




\section{Simulated Groundwater Levels Within the County-Scale Model}

Time series of simulated and measured daily mean groundwater levels were compared, and fit statistics were calculated for 15 observation sites throughout the county-scale model area. The 15 chosen observation sites form 5 east-to-west transects (fig. 8). Simulated groundwater levels exhibit similar trends and peaks to measured values at monitoring locations. The simulated hydrographs at groundwater wells G-853 and G-2395 display the largest deviations from measured values, likely caused by the nearby presence of production well fields, which may be over- or under-represented in the model because of the scale of model discretization (figs. 9 and 10). Time-series comparisons for G-2294 were created, but fit statistics were not calculated because of the limited number of observations at this location.

The MD varied from $-1.605 \mathrm{ft}$ to $6.661 \mathrm{ft}$ for observations in the county-scale model near pumping wells $(\mathrm{G}-853$ and G-2395, respectively). The mean MD for all observation locations within the county-scale model area was $0.389 \mathrm{ft}$; however, the mean MD is reduced to $0.032 \mathrm{ft}$ when the two locations near pumping wells (G-2395 and G-853) are excluded. The RMSD varied from $0.343 \mathrm{ft}$ to $6.829 \mathrm{ft}$, with a mean of $1.123 \mathrm{ft}$ for all observation locations within the county-scale model area or a mean of $0.563 \mathrm{ft}$ if G-2395 and $\mathrm{G}-853$ were excluded. The PEV ranged from 10.5 percent to 70.7 percent, with an average of 45.3 percent for all observation locations (table 2).

\section{Simulated Groundwater Levels Within the Local- Scale Model}

Model fit was evaluated for the three groundwaterobservation locations within the local-scale model area. Like the county-scale model, local-scale simulation results showed qualitatively similar mean groundwater-level values and lower peak values as compared to measured (fig. 11). The mean MD for the three groundwater-observation locations in the local-scale model is $0.125 \mathrm{ft}$, and the mean RMSD is $0.630 \mathrm{ft}$. The highest difference in PEV occurred at G-617, the westernmost well. Within this observation location, the calculated PEV was -16.9 percent in the local-scale model, compared to 10.5 percent in the county-scale model. The reason for this difference in PEV can be attributed to the higher variability of the groundwater levels within the local-scale model, coupled with small differences in timing. Qualitatively, the local-scale model shows an improved ability to capture the magnitude of the peaks within the simulated and measured groundwater levels, whereas the PEV is substantially lower than calculated in the county-scale model because of the shift in the timing of the peak water levels. Smaller differences in PEV were seen at the other two locations (table 3 ).

\section{Simulated Stages and Flows at Surface-Water Control Structures Within the County-Scale Model}

Time series of simulated and observed daily upstream stages and flows through the primary active structures within the county-scale model were compared, and error statistics were calculated for these structures $(\mathrm{G}-54, \mathrm{~S}-13$, S-9, and S-33; fig. 1). In the models, the surface-water control structures are simulated according to operational rules, which generally establish thresholds at which specified actions are implemented. In practice, operations of the structures are more complex and ad hoc, operational rules are commonly overridden and manual adjustments are made to address specific conditions. Each of the surface-water control structures has a unique set of operating instructions. Differences between the control structure operation rules and actual operations result in differences between simulated and measured upstream stages and structure flows, which are reflected in resulting model-fit statistics. Furthermore, the county-scale model utilizes mean daily tidal stage input, and the local-scale model utilizes mean hourly tidal stage input, compared to actual continually changing tidal stage, which affects the simulated structure operations.

The structure at G-54 (fig. 1) is a gated spillway that was designed to open when upstream stage on the North New River Canal rises above $2.899 \mathrm{ft}$ NAVD 88 and to close when upstream stage declines to $1.899 \mathrm{ft}$ above NAVD 88 . For much of the study period, actual operations followed the operating rules closely, as shown by the similarity between county-scale model-simulated and measured upstream stage values (fig. 12A). During several periods starting in mid-1995, measured stage dropped below the lower threshold for a variety of possible reasons. The magnitude and timing of simulated flow through this structure is generally similar to the measured flows (fig. 12B). The simulated flow shows a base level of flow of approximately 200 cubic feet per second $\left(\mathrm{ft}^{3} / \mathrm{s}\right)$, which generally drops to zero when upstream stages drop below the lower operating threshold. This base level of simulated flow is likely an artifact of a continuous contribution to the North New River Canal from the model boundary condition at the southern edge of the WCA2, where groundwater is leaking into the canal because of a hydraulic gradient at that boundary. The controlling head at this model boundary is taken from the Everglades Depth Estimation Network (EDEN) (Telis, 2006), which tends to overestimate water levels at this location because it is at the edge of the area defined by EDEN. This base level of simulated flow is also evidenced in the generally higher simulated than measured flows during high-flow $\left(>1,000 \mathrm{ft}^{3} / \mathrm{s}\right)$ periods. The MD between simulated and measured upstream stage is $0.029 \mathrm{ft}$, indicating that the simulated stage is generally slightly higher than the measured stage (table 4). The RMSD of upstream stage is indicative of the magnitude of the difference between the simulated and measured flows, and is $0.461 \mathrm{ft}$. The large negative value of the PEV (-50.1 percent) for the 


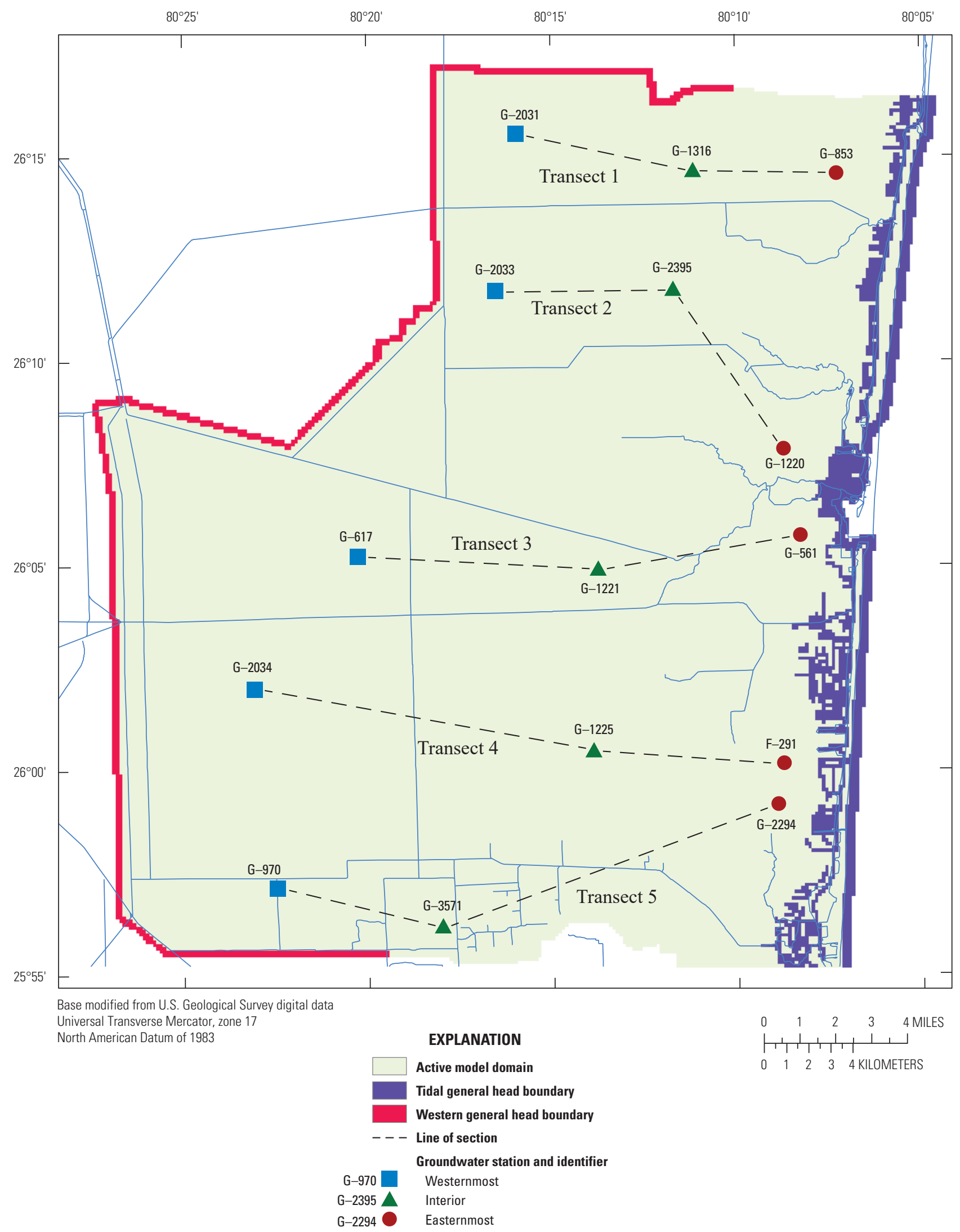

Figure 8. Groundwater-level observation locations and transects. 


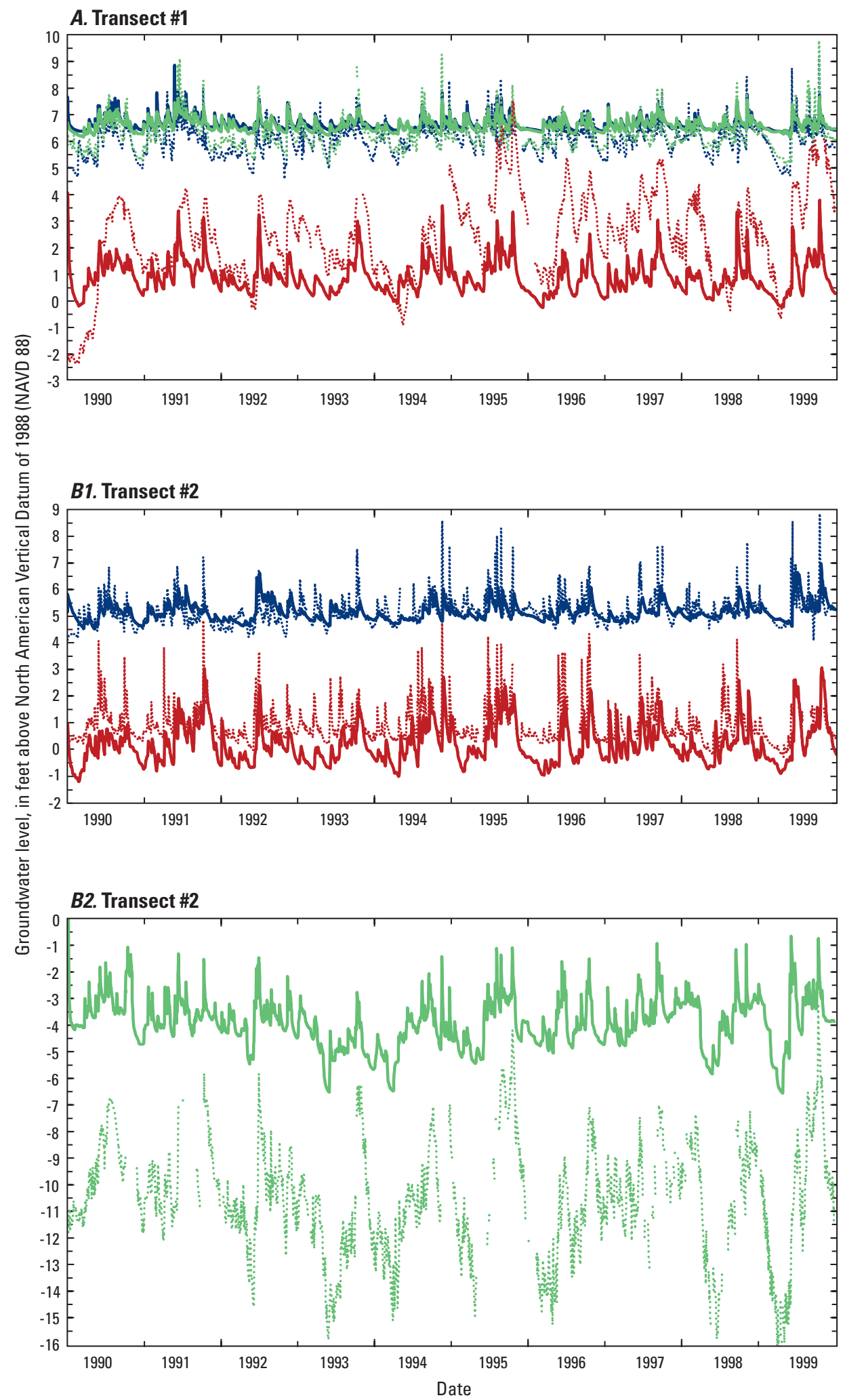

EXPLANATION

Groundwater level, by site and method

G-2031 (Simulated)

G-2031 (Measured)

G-1316 (Simulated)

G-1316 (Measured)

G-853 (Simulated

EXPLANATION

Groundwater level, by site and method

G-2033 (Simulated)

G-2033 (Measured)

G-1220 (Simulated)

G-1220 (Measured)

EXPLANATION

Groundwater level, by site and method

G-2395 (Simulated)

G-2395 (Measured)

Figure 9. Simulated and measured groundwater levels for county-scale model transects 1 and 2 during 1990-99. 


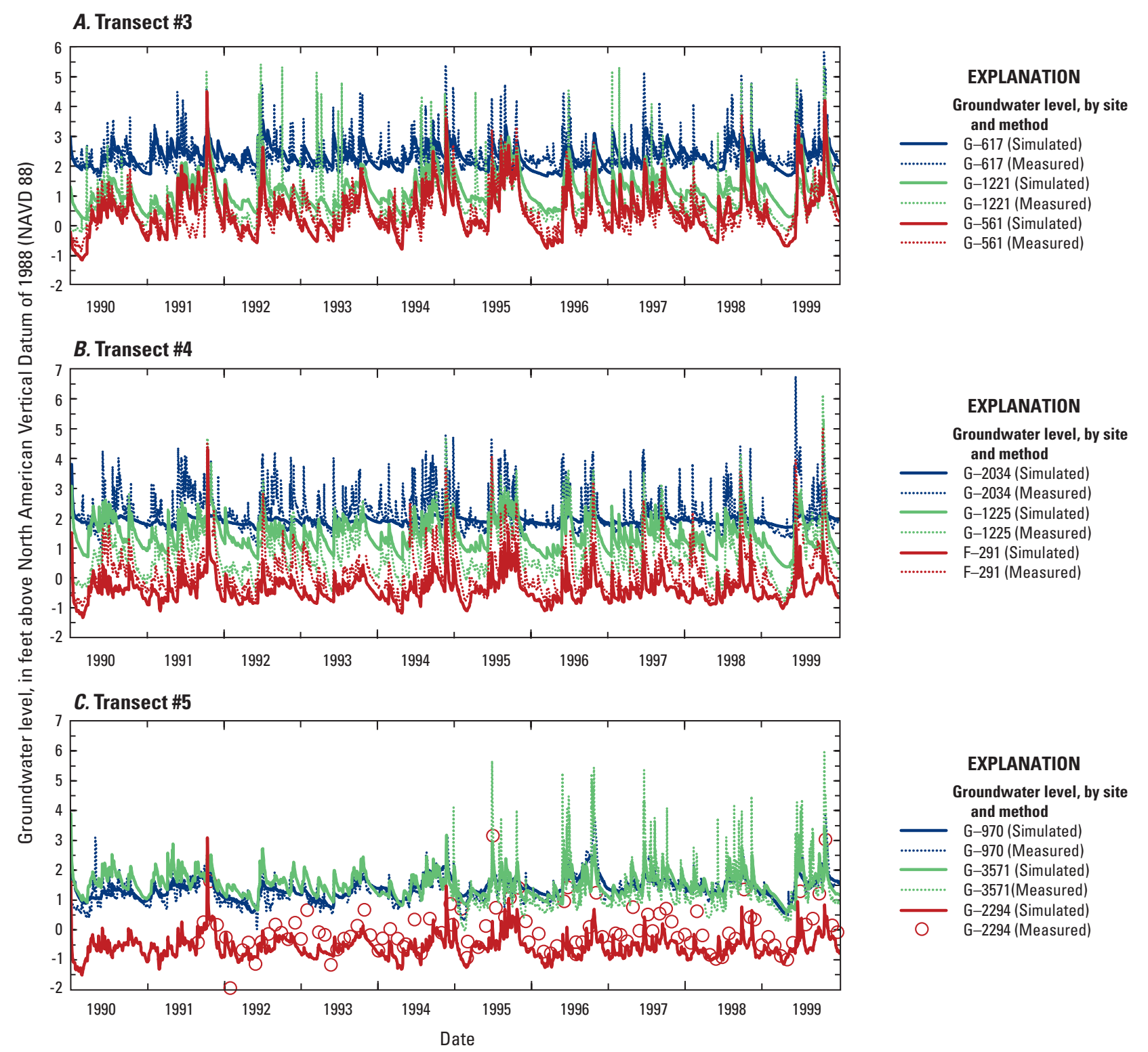

Figure 10. Simulated and measured groundwater levels for county-scale model transects 3,4 , and 5 during 1990-99.

upstream stage is a result of the differences in simulated structure operations and discharge timing/rates compared to the actual operations, which cause subsequent differences in upstream stage increases and decreases. The higher values of MD $\left(106.1 \mathrm{ft}^{3} / \mathrm{s}\right)$ and RMSD $\left(209.8 \mathrm{ft}^{3} / \mathrm{s}\right)$ of the simulated G-54 structure flow can be attributed to the aforementioned base-level flow. The larger positive value of PEV of structure flow, 49.5 percent, indicates that the mean of the simulated error/variance is closer to the mean of the measured error/variance.

The S-33 structure on the $\mathrm{C}-12 \mathrm{Canal} / \mathrm{North}$ Fork New River (fig. 1) is a gated spillway that was designed to open when the upstream stage on the $\mathrm{C}-12$ Canal rises above $2.5 \mathrm{ft}$ above NAVD 88 and close when the stage falls to $1.5 \mathrm{ft}$ above NAVD 88 (fig. 12C). In general, the actual operations of the control structure closely followed the operating rules, as indicated by the similarity between the county-scale model-simulated and measured stages. Likewise, the simulated and measured flows at the structure are similar (fig. 12D). The MD between simulated and measured upstream stage is $-0.070 \mathrm{ft}$, indicating that the simulated stage is very near measured values (table 4$)$. The RMSD $(0.400 \mathrm{ft})$ is indicative of the magnitude of the difference between the simulated and measured upstream stages. The large negative value of the PEV (-33.4 percent) of upstream stages again indicates differences in simulated structure operations compared to the actual operations, resulting in changes in upstream stages with varying discharge timing and rates. The MD of the structure flow is $10.2 \mathrm{ft}^{3} / \mathrm{s}$; the RMSD is $32.9 \mathrm{ft}^{3} / \mathrm{s}$. The large negative value of the PEV of structure flow (-44.7 percent) can be attributed to the differences in simulated structure operation and resulting discharge timing and rates. 


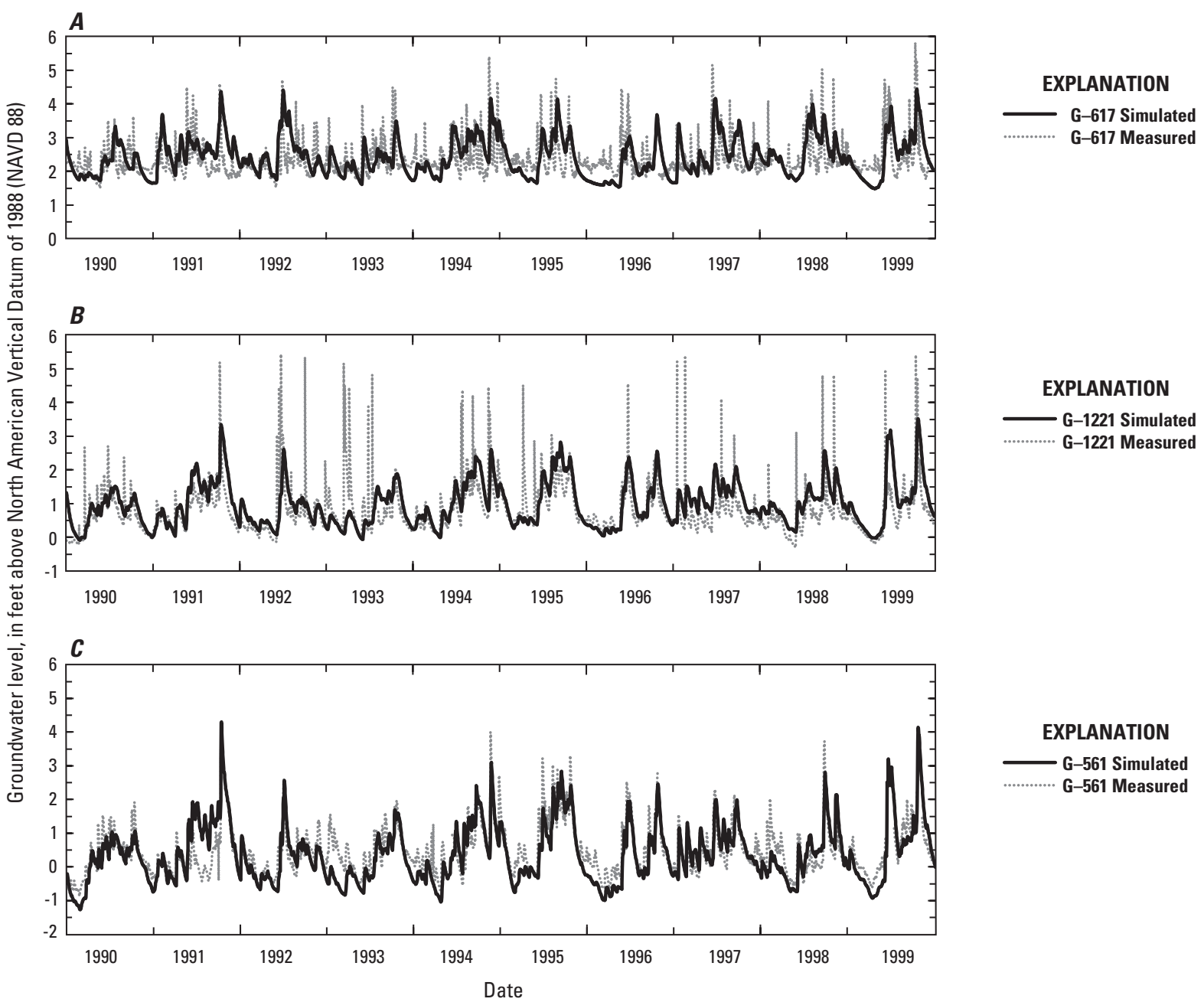

Figure 11. Simulated and measured groundwater levels for three observation locations $(A, \mathrm{G}-617 ; B, \mathrm{G}-1221$; and $C, \mathrm{G}-561)$ within the local-scale model during 1990-99.

The $\mathrm{S}-13$ structure on the $\mathrm{C}-11$ Canal (fig. 1) consists of both a gated spillway and a pump. During 1990-99, the structure was designed to operate by opening the spillway when upstream stage rose above $0.2 \mathrm{ft}$ and close when the stage declined to $-0.2 \mathrm{ft}$. The pump was designed to pump water from the upstream side of the structure to the downstream side (to tide) based on a linear stage-discharge function. The stage-discharge function begins pumping water at $0.7 \mathrm{ft}$ and reaches a maximum rate of $540 \mathrm{ft}^{3} / \mathrm{s}$ at $1.7 \mathrm{ft}$. Results from the county-scale model simulation indicate that actual operations at the S-13 structure diverged frequently from operational rules during 1990-99. During the study period, the upstream stage was frequently allowed to drop below the lower control elevation of $-0.2 \mathrm{ft}$ above NAVD 88 (fig. 13A), often to between -1.5 and $-2.0 \mathrm{ft}$ above NAVD 88 . During the study period, actual pumping also occurs more frequently than operating rules would indicate (fig. 13C). Measured periods of pumping correspond well with periods when the upstream stage dropped below 0.0 above NAVD 88 , indicating that the lower upstream stages were not largely due to natural causes, such as drought, but more likely due to some other decisional factors to move water out of the canal upstream of the structure (for example, to reduce the potential for flooding during precipitation events or pluvial periods). The MD between simulated and measured upstream stage is $0.168 \mathrm{ft}$, indicating that the simulated stage is generally larger than the measured stage (table 4$)$. The RMSD $(0.379 \mathrm{ft})$ is indicative of the magnitude of the difference between the simulated and measured upstream stages. The negative value of the PEV (-15.6 percent) of upstream stages again indicates the differences in the timing of simulated structure operations compared to actual gate operations during this period. The MD of the structure flow is $-3.3 \mathrm{ft}^{3} / \mathrm{s}$; the RMSD is $107.9 \mathrm{ft}^{3} / \mathrm{s}$. The negative value of PEV (-15.6 percent) of structure flow indicates timing and flow rate differences in the simulated structure operations but shows more similar variance than simulated stage.

The S-9 structure near the intersection of the $\mathrm{L}-37$ Canal, the $\mathrm{L}-33$ Canal, and the western part of the $\mathrm{C}-11$ Canal (fig. 1) was designed to route water from the western part of the $\mathrm{C}-11$ Canal westward into WCA 3 during 1990-99. The structure is represented as a linear stage-discharge function that begins pumping water at $1.5 \mathrm{ft}$ and reaches a maximum rate of 
Table 3. Fit statistics for groundwater levels at three monitoring locations and upstream stage and flow through primary active control structures for historical local-scale model simulation.

[ft, foot; $\mathrm{ft}^{3} / \mathrm{s}$, cubic foot per second]

\begin{tabular}{|c|c|c|c|}
\hline \multicolumn{4}{|c|}{ Groundwater levels at monitoring locations } \\
\hline $\begin{array}{c}\text { Station } \\
\text { name }\end{array}$ & $\begin{array}{c}\text { Mean } \\
\text { difference } \\
\quad(\mathrm{ft})\end{array}$ & $\begin{array}{l}\text { Root-mean- } \\
\text { square } \\
\text { difference } \\
\text { (ft) }\end{array}$ & $\begin{array}{c}\text { Explained } \\
\text { variance } \\
\text { (percent) }\end{array}$ \\
\hline G-617 & -0.050 & 0.577 & -16.9 \\
\hline G-1221 & 0.413 & 0.771 & 16.7 \\
\hline G-561 & 0.011 & 0.541 & 39.1 \\
\hline Mean & 0.125 & 0.630 & NA \\
\hline \multicolumn{4}{|c|}{ Upstream stage } \\
\hline Structure & $\begin{array}{c}\text { Mean } \\
\text { difference } \\
\text { (ft) }\end{array}$ & $\begin{array}{l}\text { Root-mean- } \\
\text { square } \\
\text { difference } \\
\text { (ft) }\end{array}$ & $\begin{array}{c}\text { Explained } \\
\text { variance } \\
\text { (percent) }\end{array}$ \\
\hline G-54 & 0.135 & 0.479 & -49.3 \\
\hline $\mathrm{S}-13$ & 0.135 & 0.351 & -5.4 \\
\hline \multicolumn{4}{|c|}{ Simulated structure flow } \\
\hline Structure & $\begin{array}{c}\text { Mean } \\
\text { difference } \\
\left(\mathrm{ft}^{3} / \mathrm{s}\right)\end{array}$ & $\begin{array}{l}\text { Root-mean- } \\
\text { square } \\
\text { difference } \\
\left(\mathrm{ft}^{3} / \mathrm{s}\right) \\
\end{array}$ & $\begin{array}{c}\text { Explained } \\
\text { variance } \\
\text { (percent) }\end{array}$ \\
\hline $\mathrm{G}-54$ & 104.4 & 208.4 & 49.9 \\
\hline S-13 (spillway) & 11.1 & 98.6 & -11.8 \\
\hline
\end{tabular}

Table 4. Fit statistics for upstream stage and flow through primary active control structures for historical county-scale model simulation.

[ft, foot; $\mathrm{ft}^{3} / \mathrm{s}$, cubic foot per second]

\begin{tabular}{lccc}
\hline \multicolumn{1}{c}{ Structure } & $\begin{array}{c}\text { Mean } \\
\text { difference } \\
\text { (ft) }\end{array}$ & $\begin{array}{c}\text { Root-mean- } \\
\text { square } \\
\text { difference } \\
\text { (ft) }\end{array}$ & $\begin{array}{c}\text { Explained } \\
\text { variance } \\
\text { (percent) }\end{array}$ \\
\hline G-54 & 0.029 & 0.461 & -50.1 \\
S-13 & 0.168 & 0.379 & -15.6 \\
S-33 & -0.070 & 0.400 & -33.4 \\
S-9 & 0.116 & 0.897 & -8.3 \\
\hline Simulated structure flow & \\
\hline Structure & $\begin{array}{c}\text { Mean } \\
\text { difference } \\
\text { (ft } 3 \text { /s) }\end{array}$ & $\begin{array}{c}\text { square } \\
\text { difference } \\
\text { (ft } 3 \text { /s) }\end{array}$ & $\begin{array}{c}\text { Explained } \\
\text { variance } \\
\text { (percent) }\end{array}$ \\
\hline G-54 & 106.1 & 209.8 & 49.5 \\
S-13 (spillway) & -3.3 & 107.9 & -0.1 \\
S-33 & 10.2 & 32.9 & -44.7 \\
S9 & -30.0 & 299.0 & 29.7 \\
\hline
\end{tabular}

$1,000 \mathrm{ft}^{3} / \mathrm{s}$ at $2.0 \mathrm{ft}$ above NAVD 88 (fig. 14A). During the study period, results from the county-scale model show that measured stages and flows differed substantially from operational controls (figs. 14A, $B$ ), indicating that actual operations commonly diverged from the specified operational rules. The MD between simulated and measured upstream stage is $0.116 \mathrm{ft}$, indicating that the simulated stage is generally larger than the measured stage (table 4). The RMSD is indicative of the magnitude of the difference between the simulated and measured upstream stages, and is $0.897 \mathrm{ft}$. The small negative value of the PEV (-8.3 percent) of upstream stages indicates differences in the timing of structure flows and resulting stage values. The MD of the structure flow is $-30.0 \mathrm{ft}^{3} / \mathrm{s}$, the RMSD is $299.0 \mathrm{ft}^{3} / \mathrm{s}$, and the value of $\mathrm{PEV}$ is 29.7 percent.

\section{Simulated Stages and Flows at Surface-Water Control Structures Within the Local-Scale Model}

Time series of simulated and observed daily upstream stages and flows through G-54 and S-13 were also compared for the local-scale model, and error statistics were calculated for these structures (fig. 3). Differences between local-scale simulated and measured upstream stages and structure flows at G-54 and S-13 (fig. 15) were similar to differences between the county-scale simulated and measured upstream stages and structure flows for the study period (figs. 12A, $B$, and 13). Fit statistics for these structures generated from the results of the local-scale model (table 3 ) are also similar to the fit statistics generated from the results of the county-scale model (table 4).

\section{Summary of Model Fit to Historical Conditions}

Both models produce similar overall groundwater levels compared to measured levels, with MDs of $0.032 \mathrm{ft}$ (when excluding two observation sites near production wells) and $0.125 \mathrm{ft}$ for the county- and local-scale models, respectively. The county- and local-scale models produced qualitatively similar groundwater-level time series to those measured. Both models tend to simulate lower peak values than those measured, with the local-scale model capturing higher peaks than the county-scale model because of the finer grid resolution. There are small shifts in the timing of peak values evidenced in the time-series plots and the PEV statistics.

The county- and local-scale models produced similar results to one another for the primary structure flows. The mean upstream stage values at these structures were similar to measured values, with ranges of MDs of $-0.070-0.168 \mathrm{ft}$ and values of $0.135 \mathrm{ft}$ for the county- and local-scale models, respectively. The timing and values of discharges through these structures vary from measured values because of the models' use of operational rules that vary from actual operations. The behavior and intent of the drainage system are captured by using the specified operational rules and were used to operate the structure when testing various future scenarios. 


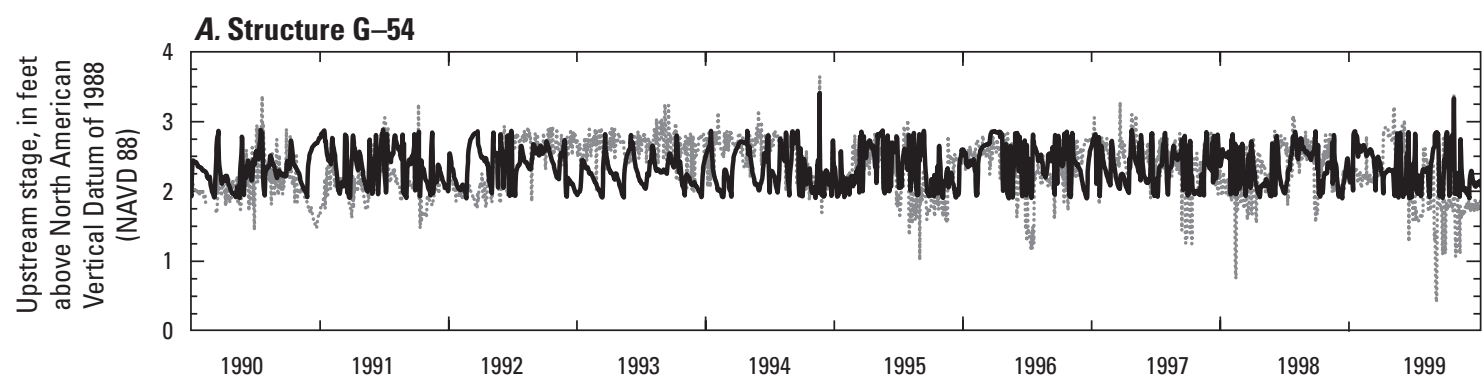

EXPLANATION

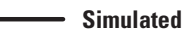

Measured

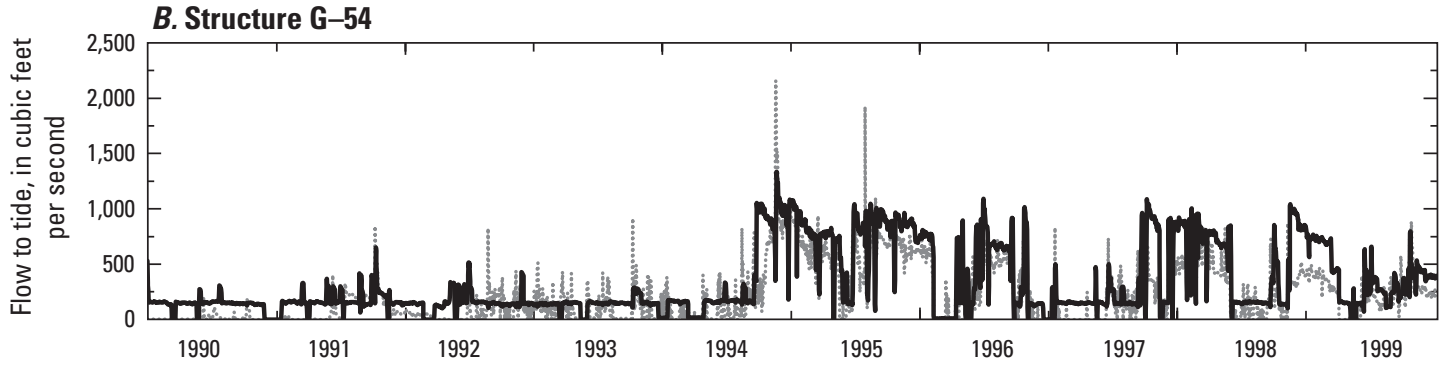

EXPLANATION

Simulated Measured

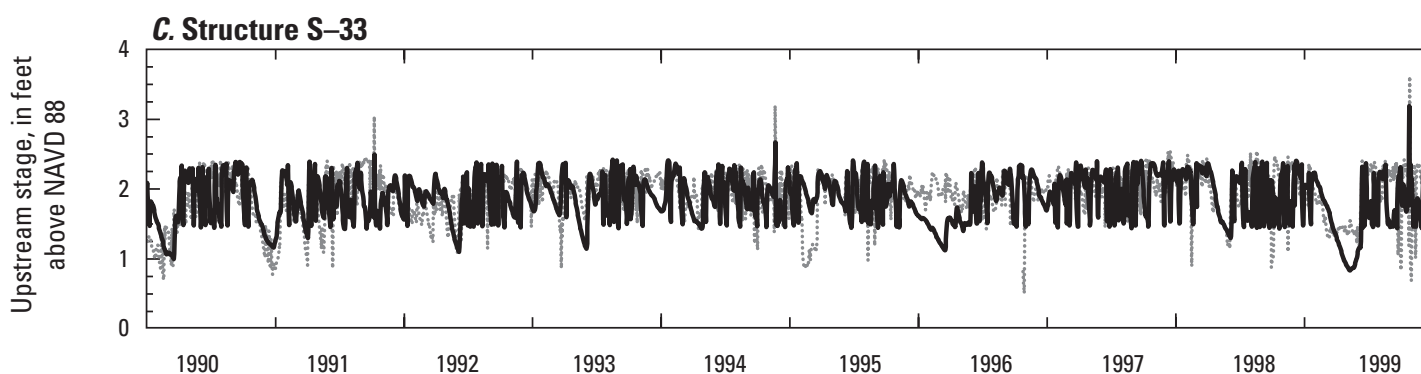

EXPLANATION

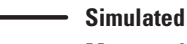
Measured

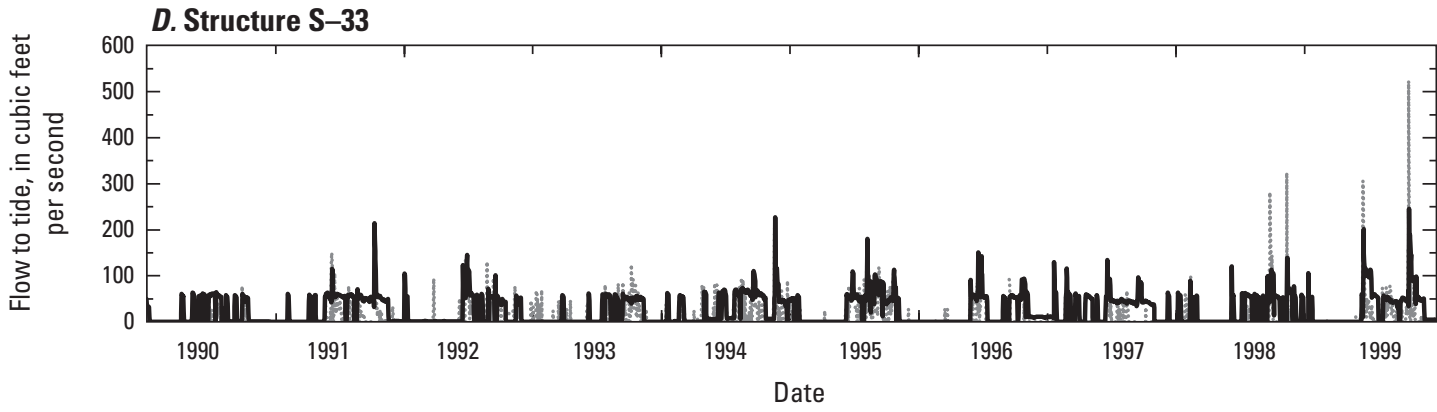

EXPLANATION

Figure 12. Simulated and measured upstream stage and flow at primary active structures $\mathrm{G}-54$ $(A, B)$ and $\mathrm{S}-33(C, D)$ during $1990-99$ for the county-scale model.

Although no formal calibration was performed and parameters were derived primarily from existing models, the groundwater and surface-water results indicate that the overall behavior of the hydrologic system, under historical conditions, is well represented by the inundation models. Using these models as a tool to simulate changes in groundwater levels and surface-water drainage that are due to projected future climate and sea-level changes would provide insight into how the system may respond under these new conditions. As with most models, more focus should be placed on the qualitative effects within the output rather than exact quantitative results. The comparison of output from various scenarios and differences between these scenarios will provide the most insight.
Effects of Climate Changes and Sea-Level Rise on Groundwater Levels, Canal Stages, and Flows at Coastal Structures

To evaluate effects of climate changes, specifically changes in precipitation and ET, and sea-level rise on the potential for inundation in Broward County, scenarios were simulated by using the county-scale and local-scale models, representing two different climates and three rates of sea-level rise, for a future 10-year period. First, two climate model output datasets were used to generate climate 

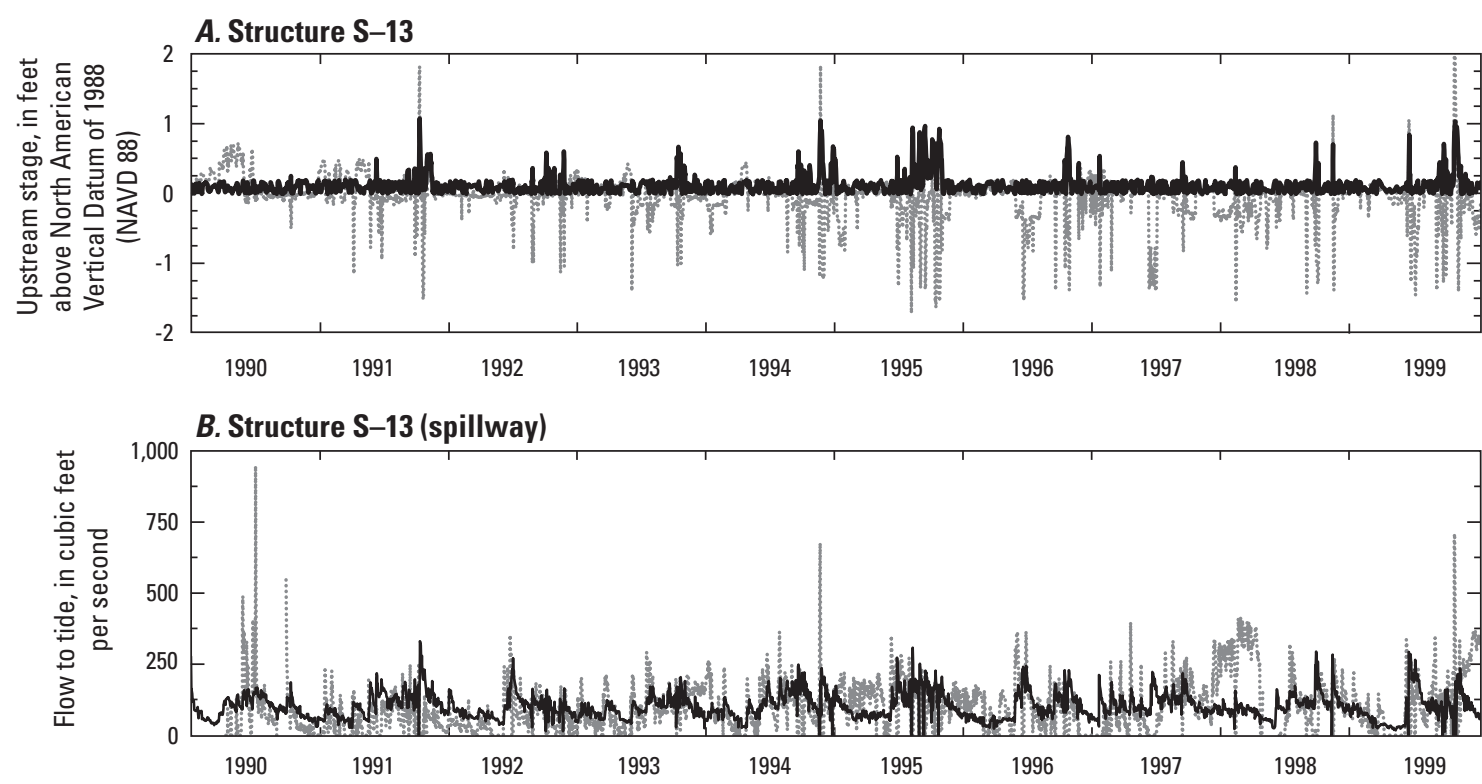

EXPLANATION

Simulated

Measured

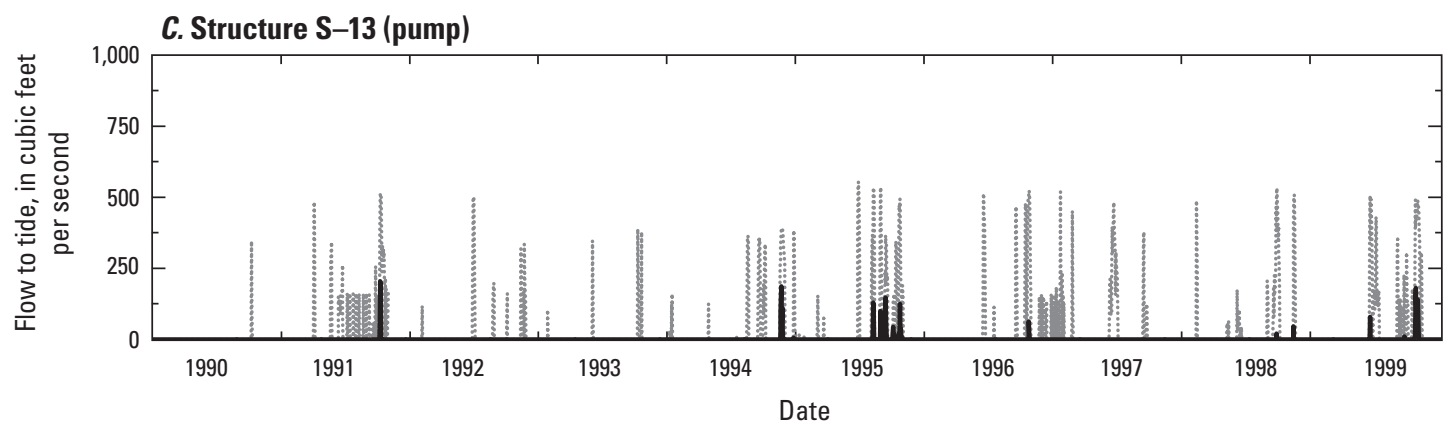

EXPLANATION

Simulated

Measured

Figure 13. Simulated and measured upstream stage and flow at primary active structure $\mathrm{S}-13$ during 1990-99 for the county-scale model.
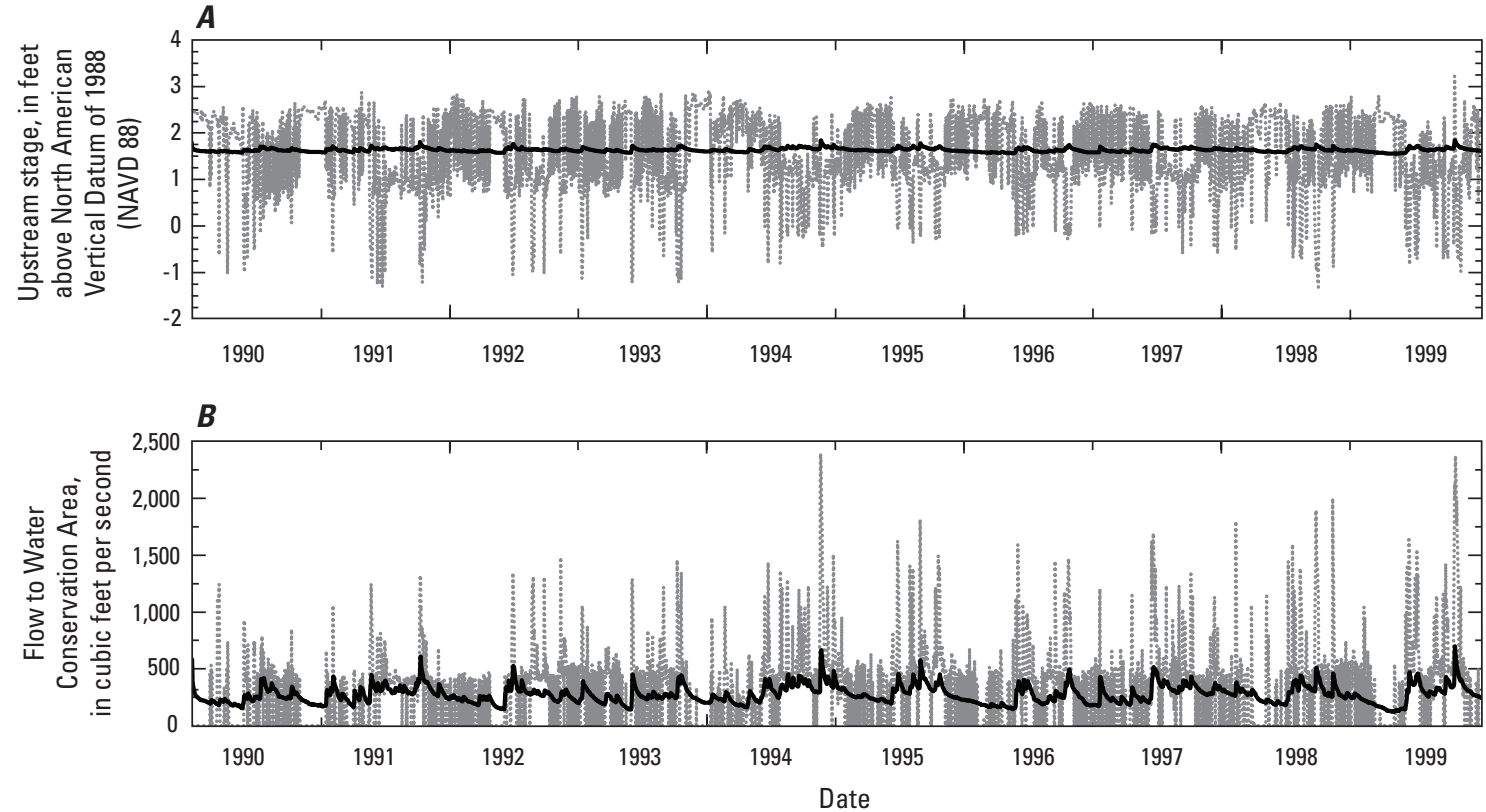

Figure 14. Simulated and measured upstream stage and flow at primary active structure S-9 during 1990-99 for the county-scale model. 


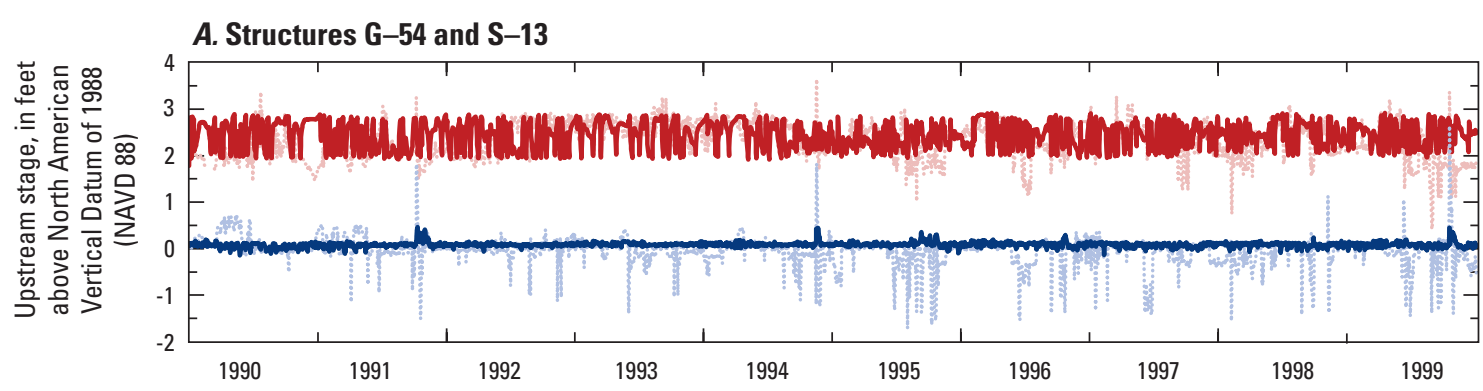

EXPLANATION

- G-54 Simulated G-54 Measured

- S-13 Simulated S-13 Measured

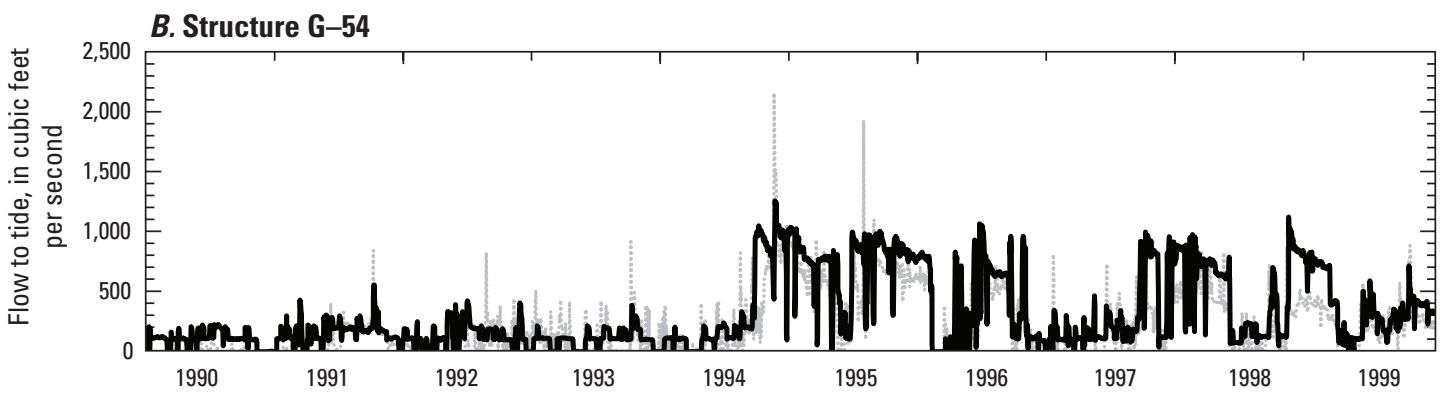

EXPLANATION

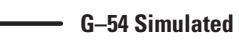
G-54 Measured

C. Structure S-13

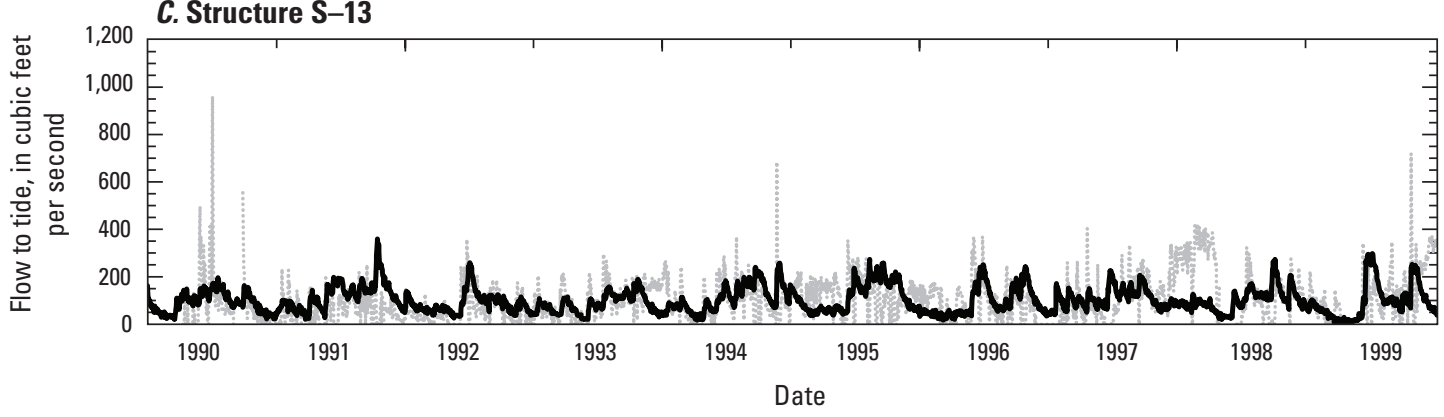

EXPLANATION

S-13 Simulated S-13 Measured

Figure 15. Simulated and measured headwater stage and flow at structures $G-54(A, B)$ and S-13 (C) for the local-scale model during 1990-99.

conditions during 1990-99 and during 2060-69, which corresponded to the latest period of the available output. Precipitation and potential ET output from these climate simulations were then used as input for the county-scale and local-scale models, and hydrologic conditions were simulated by using combinations of climate and sea-level variations during 1990-99 and 2060-69.

\section{Simulation of Climate Conditions During 1990-99 and 2060-69}

Two global circulation models (GCMs), the CCSM and the HadCM3, were selected and applied by COAPS to their regional-scale climate model to generate estimates and projections of precipitation and potential ET for base-case and future periods for the study area. The AR4 A2 emissions scenarios, which were used for these simulations, assume a more heterogeneous developing world with increasing global population (IPCC, 2007). The COAPS regional climate model has a resolution of 10 kilometers $(\mathrm{km})$ by $10 \mathrm{~km}$ and simulates a historical period from 1968-99 and a future period from 2038-69. At this resolution, the county-scale study area used output from approximately 56 climate model cells, and the local-scale study area used output from 3 of those climate model cells (appendix 2). The downscaled climate model output was provided as daily values of bias-corrected precipitation and potential ET. A truncated 10-year simulation period was used because of computational time limitations, and the furthest projected available climate data period, 2060-69, was used. These future condition scenarios are just two of a multitude of possible realizations of future climate and weather.

Regional model precipitation output for 1990-99 within the county-scale study area varied between $39.2 \mathrm{in} / \mathrm{yr}$ and $65.0 \mathrm{in} / \mathrm{yr}$, with an average of $53.4 \mathrm{in} / \mathrm{yr}$, for the CCSM climate simulation and varied between $31.7 \mathrm{in} / \mathrm{yr}$ and $72.6 \mathrm{in} / \mathrm{yr}$, with an average of $54.9 \mathrm{in} / \mathrm{yr}$, for the HadCM3 climate simulation (fig. 16A). Both climate simulations represent drier conditions during 1990-99 when compared to the measured average of $62.5 \mathrm{in} / \mathrm{yr}$ during this time. Despite drier simulated average conditions during 1990-99, the two climate simulations had wet-season totals similar to measured 1990-99 wet-season totals, where the wet season is defined as May 1 to October 31. 


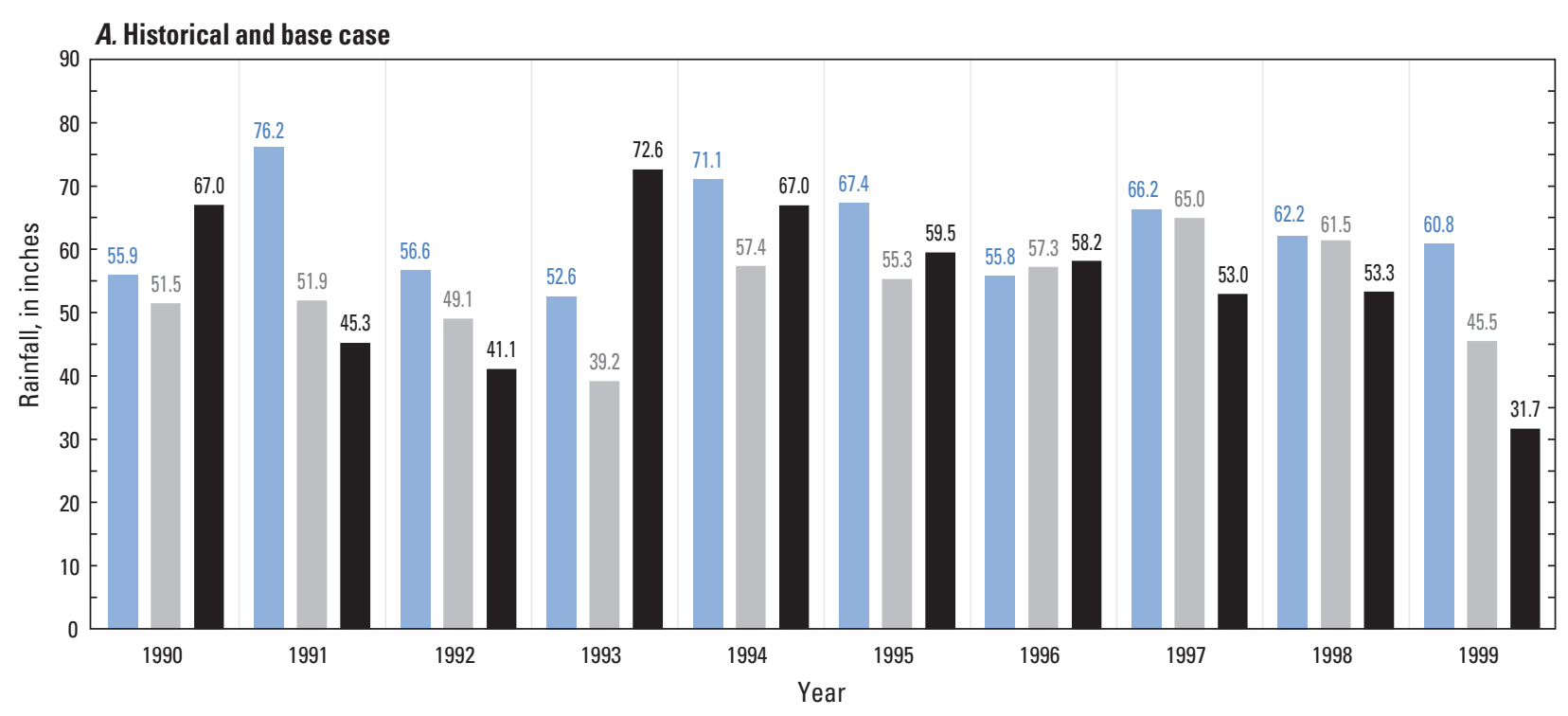

EXPLANATION

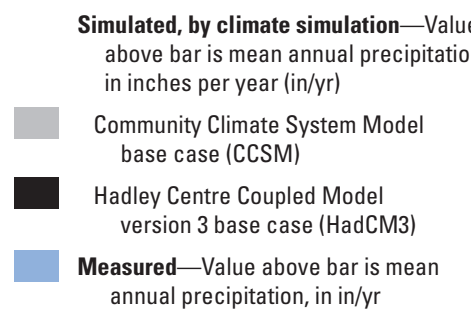

B. Future scenario

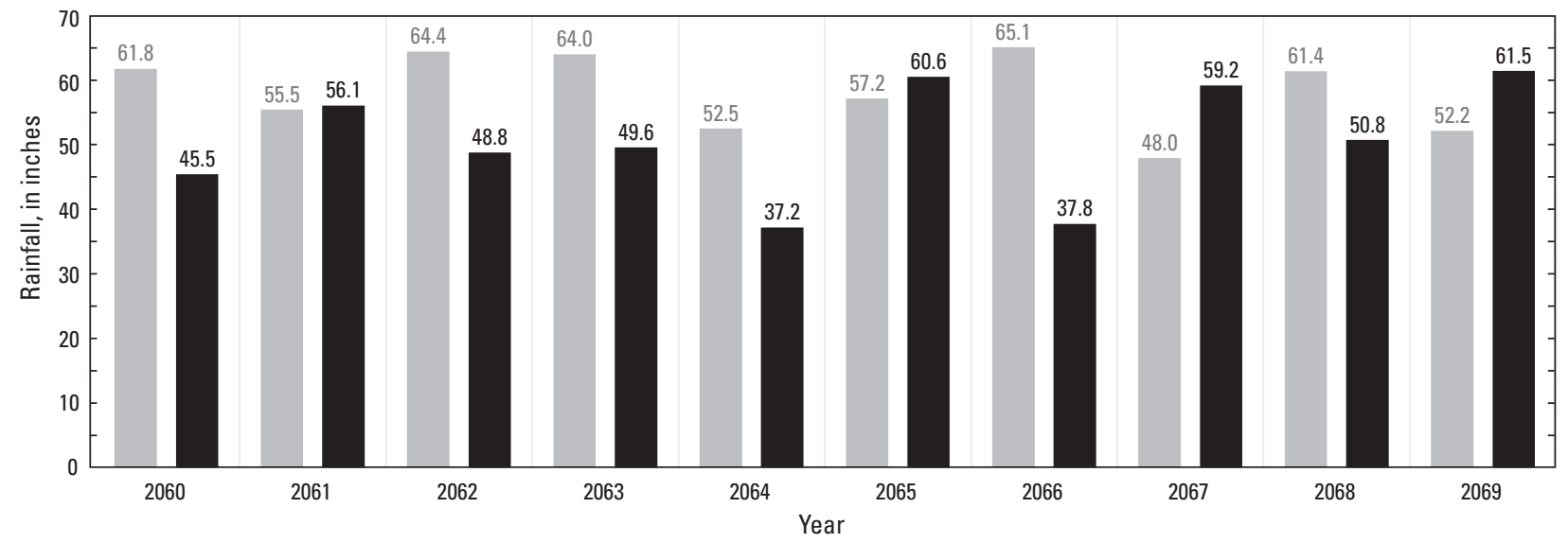

EXPLANATION

Simulated, by climate simulation-Value

above bar is mean annual precipitation,

in in/yr

CCSM-Wetter

HadCM3-Drier

Figure 16. Mean rainfall, in inches, for the county-scale model area. $A$, measured and simulated values for the Community Climate System Model (CCSM) and Hadley Centre Coupled Model version 3 (HadCM3) climate simulations during 1990-99, and B, simulated values for the CCSM and HadCM3 climate simulations during 2060-69. 
The percentage of total wet-season precipitation relative to total annual precipitation was 72.5 percent for the CCSM climate simulation and 75.0 percent for the HadCM3 climate simulation compared with 68.8 percent for measured precipitation during 1990-99. The average wet-season precipitation total was 38.7 in. for the CCSM climate simulation and 40.0 in. for the HadCM3 climate simulation during 1990-99 compared to an average measured wet-season total of 43.0 in. during that period.

Regional climate-model-predicted precipitation for the county-scale model during 2060-69 varied between $48.0 \mathrm{in} / \mathrm{yr}$ and $65.1 \mathrm{in} / \mathrm{yr}$, with an average of $58.2 \mathrm{in} / \mathrm{yr}$, for the CCSM climate simulation, and varied between $37.2 \mathrm{in} / \mathrm{yr}$ and $61.5 \mathrm{in} / \mathrm{yr}$, with an average of $50.7 \mathrm{in} / \mathrm{yr}$, for the HadCM3 climate simulation (fig. 16B). The average yearly precipitation represents a 9.1-percent increase for the CCSM climate simulation during 2060-69 compared to the 1990-99 CCSM climate simulation and a 7.6-percent decrease in average yearly rainfall for the HadCM3 climate simulation during 2060-69 compared to the 1990-99 HadCM3 climate simulation. The distinction between the wetter conditions of the CCSM climate simulation and drier conditions of the HadCM3 climate simulation are further illustrated in the cumulative differences in rainfall between each climate simulation during 2060-69 and each climate simulation during 1990-99 (fig. 17). Henceforth, the future hydrologic scenarios that use the CCSM precipitation will be referred to as "wetter future," and future hydrologic scenarios using the HadCM3 precipitation output will be referred to as "drier future."

Potential ET output within the county-scale study area for the CCSM climate simulation during 1990-99 varied between $73.5 \mathrm{in} / \mathrm{yr}$ and $76.3 \mathrm{in} / \mathrm{yr}$, with an average of $74.5 \mathrm{in} / \mathrm{yr}$; potential ET for the HadCM3 climate simulation during 1990-99 varied between $68.1 \mathrm{in} / \mathrm{yr}$ and $74.1 \mathrm{in} / \mathrm{yr}$, with an average of $71.8 \mathrm{in} / \mathrm{yr}$ (fig. 18A). These values are similar to the average yearly potential ET of $73.6 \mathrm{in} / \mathrm{yr}$ measured during the 1990-99 time period within the study area. Regional climate model potential ET output for CCSM climate simulations during 2060-69 varied between 79.4 in/yr and $84.5 \mathrm{in} / \mathrm{yr}$, with an average of $81.4 \mathrm{in} / \mathrm{yr}$; potential ET output for the HadCM3 climate simulations during 2060-69 varied between $76.3 \mathrm{in} / \mathrm{yr}$ and $82.5 \mathrm{in} / \mathrm{yr}$, with an average of 78.9 (fig. 18B). The CCSM climate simulation results during 2060-69 represent a 9.2-percent increase relative to the 1990-99 CCSM climate simulation average yearly potential ET and the HadCM3 climate simulation results during 2060-69 represent a 10.0-percent increase relative to the 1990-99 HadCM3 climate simulation average yearly potential ET. The effects of the 9.1-percent increase in wetter future scenario precipitation could be partially dampened by the increase in wetter future potential ET, but the differences in timing of the two model inputs reduce this interaction. By the same reasoning, the effects of the 7.6-percent decrease in drier future scenario precipitation is likely exacerbated by the increase in drier future increase potential ET.

The uncertainty of these projections was not considered as a part of this analysis. These scenarios are not meant to represent an exact expectation of future conditions. The uncertainty of these types of projections, especially this far into the future, is likely high, but the projections represent feasible possibilities of future conditions.

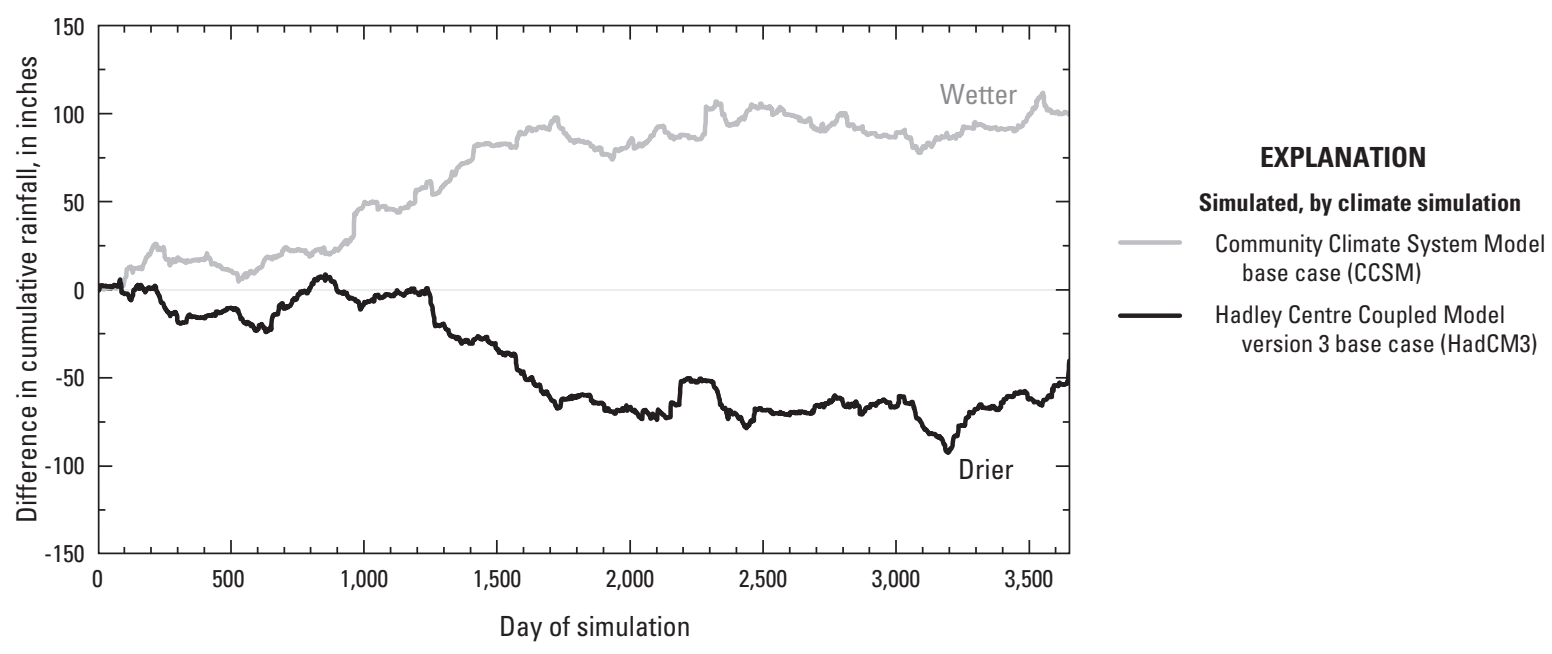

Figure 17. Cumulative difference in rainfall between the Community Climate System Model (CCSM) climate simulation during 2060-69 and the CCSM climate simulation during 1990-99, and between the Hadley Centre Coupled Model version 3 (HadCM3) climate simulation during 2060-69 and the HadCM3 climate simulation during 1990-99, averaged spatially for the county-scale model area. 


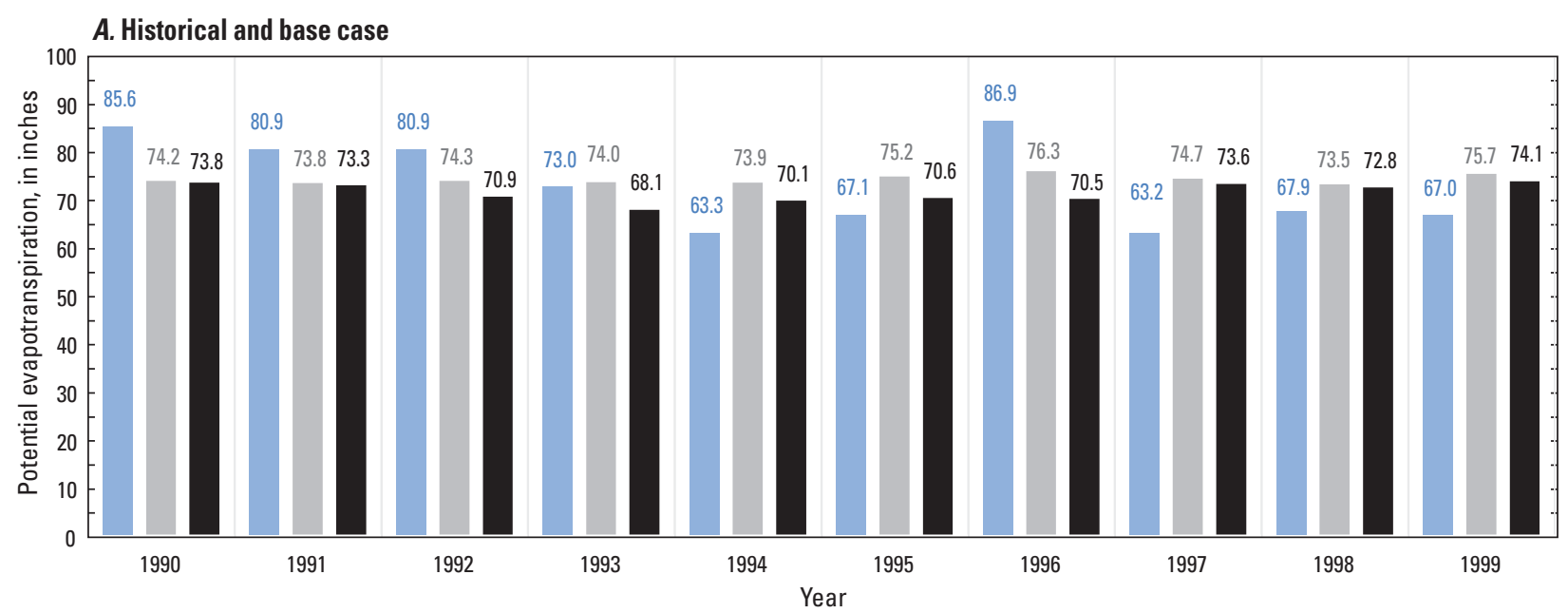

EXPLANATION

Simulated, by climate simulation-Value above bar is mean annual potential evapotranspiration (ET), in inches per year (in/yr)

Community Climate System Model base case (CCSM)

Hadley Centre Coupled Model version 3 base case (HadCM3)

Measured-Value above bar is mean annual potential ET, in in/yr

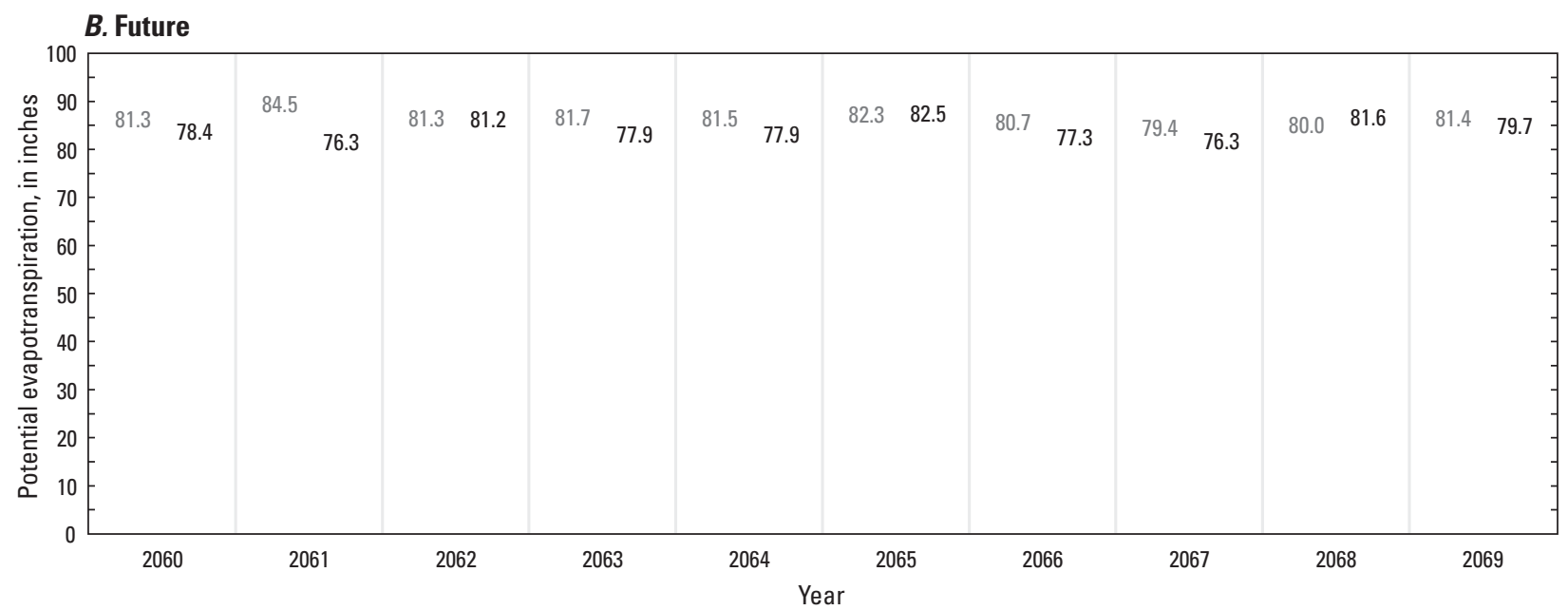

\section{EXPLANATION}

Simulated, by climate simulation-Value above bar is mean annual potential ET, in in/yr

CCSM

HadCM3

Figure 18. Mean potential evapotranspiration, in inches, for the county-scale model area. $A$, measured and simulated for the Community Climate System Model (CCSM) and Hadley Centre Coupled Model version 3 (HadCM3) climate simulations during 1990-99, and B, simulated for the CCSM and HadCM3 climate simulations during 2060-69. 


\section{Simulation of the Hydrologic System for Future Climate and Sea-Level Conditions During 2060-69}

Base-case (1990-99) and future (2060-69) conditions were simulated using the county- and local-scale models and compared to examine the hydrologic system's response. First, base-case hydrologic conditions were established for comparison purposes for the county-scale and local-scale models, representing conditions during 1990-99, by replacing the precipitation and potential ET used in the historical simulation with output from the CCSM and HadCM3 climate simulations for that time period (table 5). These conditions are called the CCSM Base-Case and HadCM3 Base-Case scenarios, respectively. Then, 2060-69 hydrologic conditions were simulated for the county-scale and local-scale models by using CCSM and HadCM3 climate simulation output and sea levels as predicted by three sea-level rise rate functions for 2060-69 (table 5). Sea-level rise scenarios were implemented to represent (1) a sustained linear sea-level rise trend derived from current and historical tidal measurements, designated as "Low Sea-Level Rise"; (2) the NRC Curve I, designated as "Intermediate Sea-Level Rise"; and (3) NRC Curve III, designated as "High Sea-Level Rise" (table 5), based on methodology established by the USACE (appendix 2). The resulting mean sea-level rise projections for the period 2010 to 2060-69 using these three sea-level rise rates are $6.2 \mathrm{in}$. $(0.52 \mathrm{ft}), 11.9$ in. $(0.99 \mathrm{ft})$, and 29.9 in. (2.49 ft), respectively (fig. 7). Results of simulations representing different climate and sea-level scenarios during 2060-69 were compared with results of the base-case scenarios to evaluate changes in groundwater levels, surface-water stages, and surface-water flows in response to projected changes in precipitation, potential ET, and sea level.

\section{County-Scale Model Scenario Results}

Results from the CCSM and HadCM3 Base-Case scenarios were compared to the results from the historical simulations and to scenarios representing each of the sea-level rise conditions (table 5). Differences in average wet-season groundwater levels, primary structure flows, and percentage of sea-level rise reflected in increased groundwater levels were calculated to evaluate the effects of potential climate and sea-level rise on the hydrologic system.

\section{Comparison of CCSM and HadCM3 Base-Case Scenarios to the Historical Simulation}

The means of the MDs in groundwater levels at the groundwater-observation locations (fig. 8) between the CCSM and HadCM3 Base-Case scenarios and the historical simulation were $-0.045 \mathrm{ft}$ and $-0.015 \mathrm{ft}$, respectively (table 6). The negative values indicate that, in general, both base-case scenarios simulate lower groundwater levels than the historical simulation. The largest MDs occurred at G-853 located near a well pumping location, which, with the drier base-case conditions, would lead to larger decreases in groundwater levels. The means of the MDs in primary structure flows between the CCSM and HadCM3 Base-Case scenarios and the historical simulation were $-11.0 \mathrm{ft}^{3} / \mathrm{s}$ and $-6.4 \mathrm{ft}^{3} / \mathrm{s}$, indicating that the base-case scenarios generally simulate smaller structure flows than does the historical simulation. The largest difference in mean flow rates through a primary active structure between the CCSM and HadCM3 BaseCase scenarios and the historical simulation occurred at S-9 and G-54 and were $-19.2 \mathrm{ft}^{3} / \mathrm{s}$ and $-10.8 \mathrm{ft}^{3} / \mathrm{s}$, respectively (table 6). These large differences are likely due to the drier base-case conditions and the larger drainage areas that discharge through the S-9 pump and G-54 gated spillway.

\section{Comparison of Sea-Level Rise and Wetter or Drier Future Scenarios With Base-Case Scenarios}

Simulation results show that the largest effects on groundwater levels attributed to changes in sea-level rise and precipitation occur in areas closest to the coast. For the wetter future scenarios, the five easternmost groundwater-station locations (G-853, G-1220, G-561, F-291, and G-2294; fig. 8) indicate average groundwater-level increases

Table 5. Project modeling scenarios incorporating sea-level rise and climate change predictions.

[ET, evapotranspiration; CCSM, Community Climate System Model; NRC, National Resource Council; HadCM3, Hadley Centre Coupled Model version 3]

\begin{tabular}{llll}
\hline \multicolumn{1}{c}{ Designation } & \multicolumn{1}{c}{ Time frame } & Precipitation/ET source & \multicolumn{1}{c}{ Sea-level rise source } \\
\hline Historical simulation & $1 / 1 / 1990-12 / 31 / 1999$ & Historical data & Historical tidal gage data \\
CCSM Base-Case scenario & $1 / 1 / 1990-12 / 31 / 1999$ & CCSM (1990-99) & Historical tidal gage data \\
Wetter future, low sea-level rise scenario & $1 / 1 / 2060-12 / 31 / 2069$ & CCSM (2060-69) & Historical linear sea-level rise trend \\
Wetter future, intermediate sea-level rise scenario & $1 / 1 / 2060-12 / 31 / 2069$ & CCSM (2060-69) & NRC Curve I projection \\
Wetter future, high sea-level rise scenario & $1 / 1 / 2060-12 / 31 / 2069$ & CCSM (2060-69) & NRC Curve III projection \\
HadCM3 Base-Case scenario & $1 / 1 / 1990-12 / 31 / 1999$ & HadCM3 (1990-99) & Historical tidal gage data \\
Drier future, low sea-level rise scenario & $1 / 1 / 2060-12 / 31 / 2069$ & HadCM3 (2060-69) & Historical linear sea-level rise trend \\
Drier future, intermediate sea-level rise scenario & $1 / 1 / 2060-12 / 31 / 2069$ & HadCM3 (2060-69) & NRC Curve I projection \\
Drier future, high sea-level rise scenario & $1 / 1 / 2060-12 / 31 / 2069$ & HadCM3 (2060-69) & NRC Curve III projection \\
\hline
\end{tabular}


Table 6. Groundwater levels and primary structure flows for the historical simulation and differences in groundwater levels and primary structure flows between Community Climate System Model (CCSM) and Hadley Centre Coupled Model version 3 (HadCM3) Base-Case scenarios and the historical simulation at groundwater-well locations shown in figure 8 and surface-water structures shown in figure 2.

[Wells grouped as westernmost, interior, and easternmost; positive values indicate an increase in groundwater levels from the historical simulation. $\mathrm{ft}$, foot; CCSM, Community Climate System Model; HadCM3, Hadley Centre Coupled Model version 3; $\mathrm{ft}^{3} / \mathrm{s}$, cubic foot per second]

\begin{tabular}{|c|c|c|c|c|}
\hline & Station name & $\begin{array}{c}\text { Historical simulation mean } \\
\text { groundwater level } \\
\text { (ft) }\end{array}$ & $\begin{array}{c}\text { CCSM Base-Case scenario } \\
\text { mean difference } \\
\text { (ft) }\end{array}$ & $\begin{array}{c}\text { HadCM3 Base-Case scenario } \\
\text { mean difference } \\
(\mathrm{ft})\end{array}$ \\
\hline \multirow{5}{*}{ 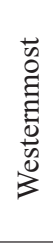 } & G-2031 & 6.631 & -0.001 & 0.008 \\
\hline & G-2033 & 5.149 & -0.013 & -0.002 \\
\hline & $\mathrm{G}-617$ & 2.263 & 0.000 & 0.038 \\
\hline & G-2034 & 2.161 & -0.203 & -0.157 \\
\hline & G-970 & 1.387 & -0.032 & -0.009 \\
\hline \multirow{5}{*}{ 莺 } & G-1316 & 6.612 & -0.025 & -0.003 \\
\hline & G-2395 & -3.828 & -0.098 & -0.037 \\
\hline & $\mathrm{G}-1221$ & 1.096 & -0.119 & -0.087 \\
\hline & G-1225 & 1.374 & -0.046 & -0.005 \\
\hline & G-3571 & 1.426 & 0.022 & 0.055 \\
\hline \multirow{5}{*}{ 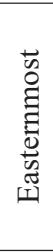 } & $\mathrm{G}-853$ & 0.794 & 0.035 & 0.055 \\
\hline & $\mathrm{G}-1220$ & 0.202 & -0.067 & -0.029 \\
\hline & G-561 & 0.340 & -0.087 & -0.037 \\
\hline & $\mathrm{F}-291$ & -0.414 & -0.020 & -0.010 \\
\hline & G-2294 & -0.593 & -0.015 & -0.010 \\
\hline & Mean & 1.640 & -0.045 & -0.015 \\
\hline & Structure & $\begin{array}{c}\text { Historical simulation } \\
\text { mean flow } \\
\left(\mathrm{ft}^{3} / \mathbf{s}\right)\end{array}$ & $\begin{array}{l}\text { CCSM Base-Case } \\
\text { mean difference } \\
\left(\mathrm{ft}^{3} / \mathrm{s}\right)\end{array}$ & $\begin{array}{c}\text { HadCM3 Base-Case } \\
\text { mean difference } \\
\left(\mathrm{ft}^{3} / \mathbf{s}\right)\end{array}$ \\
\hline & G-54 & 319.6 & -12.5 & -10.8 \\
\hline & S-13 (spillway) & 94.0 & -6.7 & -4.0 \\
\hline & $\mathrm{S}-33$ & 20.5 & -5.4 & -3.7 \\
\hline & S-9 & 288.5 & -19.2 & -7.2 \\
\hline & Mean & 180.7 & -11.0 & -6.4 \\
\hline
\end{tabular}

of $0.525 \mathrm{ft}, 0.909 \mathrm{ft}$, and $2.085 \mathrm{ft}$ for the low, intermediate, and high sea-level rise scenarios, respectively (table 7). Drier future scenarios for the five easternmost groundwater-station locations (G-853, G-1220, G-561, F-291, and G-2294) result in average groundwater-level increases of $0.329 \mathrm{ft}$, $0.716 \mathrm{ft}$, and $1.911 \mathrm{ft}$ for the low, intermediate, and high sea-level rise scenarios, respectively (table 8). These five groundwater-station locations are the closest observation locations to the sea-level boundary conditions, and thus, the resulting simulated groundwater levels are more strongly controlled by the effects of elevated sea level in the scenarios than at the interior and westernmost station locations. The groundwater level at the least affected easternmost station, $\mathrm{G}-853$, increased by $1.566 \mathrm{ft}$ and $1.390 \mathrm{ft}$ for the high sea-level rise scenario for the wetter and drier future scenarios, respectively (tables 7 and 8). Station G-853 is the northernmost coastal station and is the closest to both SWR1 specified-stage reach boundary conditions and a specified flow-pumping location. The proximity of a pumping center to this well keeps groundwater levels low, while the increased coastal groundwater levels associated with sea-level rise is reduced by the specified-stage reaches.

The westernmost groundwater station locations (G-2031, G-2033, G-617, G-2034, and G-970; fig. 8) are least affected by increasing sea level and changes in precipitation compared to the easternmost and interior observation locations. Average groundwater-level differences between the wetter future and base-case scenarios were 
Table 7. Community Climate System Model (CCSM) Base-Case groundwater levels and primary structure flows and mean differences in groundwater levels and primary structure flows between base-case and wetter future sea-level rise simulations for the county-scale model.

[Wells grouped as westernmost, interior, and easternmost; positive values indicate an increase in groundwater levels and flows from the base-case simulation. CCSM, Community Climate System Model; $\mathrm{ft}$, foot; $\mathrm{ft} / \mathrm{s}$, cubic foot per second]

\begin{tabular}{|c|c|c|c|c|c|}
\hline & Station name & $\begin{array}{l}\text { CCSM Base-Case mean } \\
\text { groundwater level } \\
\text { (ft) }\end{array}$ & $\begin{array}{l}\text { Wetter future, low } \\
\text { sea-level rise mean } \\
\text { difference } \\
\text { (ft) }\end{array}$ & $\begin{array}{c}\text { Wetter future, } \\
\text { intermediate sea-level } \\
\text { rise mean difference } \\
\text { (ft) }\end{array}$ & $\begin{array}{c}\text { Wetter future, } \\
\text { high sea-level rise } \\
\text { mean difference } \\
\text { (ft) }\end{array}$ \\
\hline \multirow{4}{*}{ 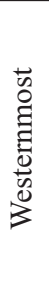 } & G-2033 & 5.137 & 0.035 & 0.041 & 0.052 \\
\hline & G-617 & 2.263 & 0.033 & 0.037 & 0.053 \\
\hline & G-970 & 1.355 & 0.005 & 0.007 & 0.010 \\
\hline & Mean & 3.469 & 0.021 & 0.024 & 0.033 \\
\hline \multirow{3}{*}{ : } & G-1316 & 6.587 & 0.041 & 0.043 & 0.049 \\
\hline & G-2395 & -3.926 & 0.104 & 0.119 & 0.163 \\
\hline & $\mathrm{G}-1221$ & 0.977 & 0.147 & 0.298 & 0.963 \\
\hline \multirow{6}{*}{ 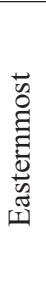 } & $\mathrm{G}-853$ & 0.829 & 0.401 & 0.691 & 1.566 \\
\hline & $\mathrm{G}-1220$ & 0.135 & 0.572 & 0.985 & 2.221 \\
\hline & $\mathrm{G}-561$ & 0.254 & 0.632 & 1.050 & 2.354 \\
\hline & $\mathrm{F}-291$ & -0.433 & 0.506 & 0.887 & 2.067 \\
\hline & G-2294 & -0.608 & 0.513 & 0.931 & 2.217 \\
\hline & Mean & 0.035 & 0.525 & 0.909 & 2.085 \\
\hline
\end{tabular}

\begin{tabular}{|c|c|c|c|c|}
\hline Structure & $\begin{array}{c}\text { CCSM Base-Case } \\
\text { mean flow } \\
\left(\mathrm{ft}^{3} / \mathrm{s}\right)\end{array}$ & $\begin{array}{c}\text { Wetter future, } \\
\text { low sea-level rise } \\
\text { mean difference } \\
\left(\mathrm{ft}^{3} / \mathrm{s}\right)\end{array}$ & $\begin{array}{c}\text { Wetter future, } \\
\text { intermediate sea-level } \\
\text { rise mean difference } \\
\left(\mathrm{ft}^{3} / \mathbf{s}\right)\end{array}$ & $\begin{array}{c}\text { Wetter future, } \\
\text { high sea-level rise } \\
\text { mean difference } \\
\left(\mathrm{ft}^{3} / \mathrm{s}\right)\end{array}$ \\
\hline G-54 & 307.1 & 6.9 & 12.2 & 21.5 \\
\hline S-13 (spillway) & 87.3 & 11.6 & 6.7 & -86.5 \\
\hline S-13 (pump) & 0.4 & 0.3 & 4.0 & 86.5 \\
\hline S-33 & 15.1 & 6.6 & 8.9 & 15.2 \\
\hline S-9 & 269.3 & 4.6 & 5.9 & 12.5 \\
\hline
\end{tabular}

$0.021 \mathrm{ft}, 0.024 \mathrm{ft}$, and $0.033 \mathrm{ft}$ in the five westernmost groundwater-station locations for the low, intermediate, and high sea-level rise scenarios, respectively. In comparison, the average groundwater-level differences between drier future and base-case scenarios were $-0.064 \mathrm{ft},-0.060 \mathrm{ft}$, and $-0.051 \mathrm{ft}$ in the five westernmost groundwater-station locations for the low, intermediate, and high sea-level rise scenarios, respectively (tables 7 and 8). This result indicates that precipitation totals have a stronger influence on groundwater levels at these westernmost station locations than tidal boundary conditions.
With increasing sea levels represented by the low, intermediate, and high sea-level rise scenarios, the west-toeast groundwater gradient during the wet season is reduced relative to historical conditions, east of the $\mathrm{S}-13 \mathrm{a}$ structure for both the wetter predicted climate conditions (fig. 19A) and drier predicted climate conditions (fig. 19B), as shown on a transect that passes through the local-scale model area (fig. 2). For all scenario simulations, structure $\mathrm{S}-13$ a effectively acts as an east-west divide of the $\mathrm{C}-11$ Canal drainage area. Groundwater levels west of this structure change little relative to historical conditions with different magnitudes of 
Table 8. Hadley Centre Coupled Model version 3 (HadCM3) Base-Case groundwater levels and primary structure flows and mean differences in groundwater levels and primary structure flows between base-case and drier future sea-level rise simulations for the county-scale model.

[Wells grouped as westernmost, interior, and easternmost; positive values indicate an increase in groundwater levels and flows from base-case simulation. HadCM3, Hadley Centre Coupled Model version 3; ft, foot; $\mathrm{ft}^{3} / \mathrm{s}$, cubic foot per second]

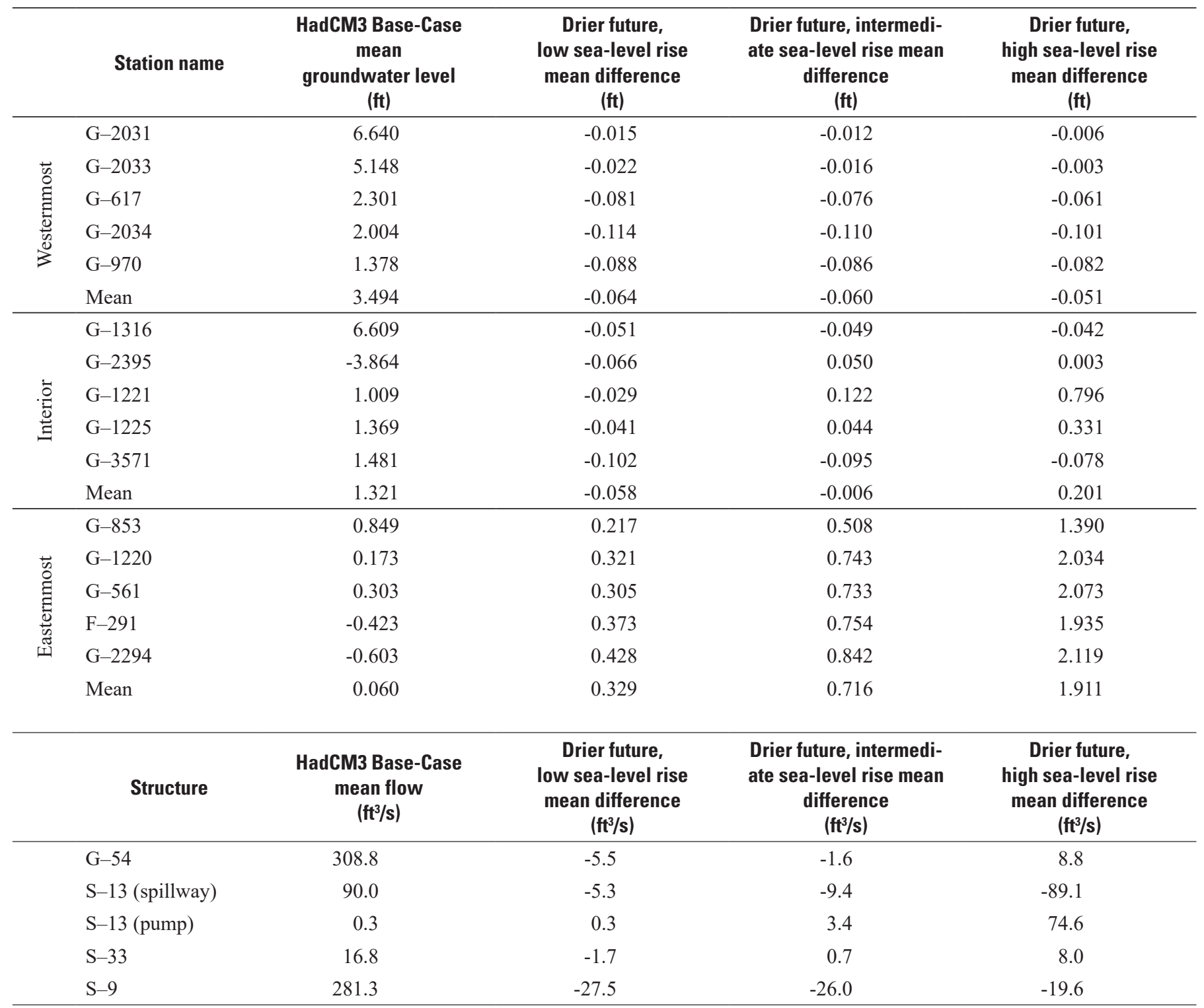

sea-level rise because, within the model, canal stages west of $\mathrm{S}-13 \mathrm{a}$ are controlled by the $\mathrm{S}-9$ structure operations. Changes in precipitation and potential ET from base-case to the future predicted climate conditions have minimal effects, as shown by slight differences between groundwater levels along the transect (figs. 19A, B). Subsequently, flow through the S-9 structure is reduced during the drier future scenario and is increased in the wetter future scenario relative to historical conditions effectively controlling C-11 Canal levels west of S-13a.

East of the $\mathrm{S}-13$ a structure, operations at the S-13 structure change for the different sea-level rise scenarios (figs. 20 and 21). The $\mathrm{S}-13$ structure has a gravity spillway and a pump, and generally operates as follows: when upstream stages are rising, the gates for the spillway are opened at an upstream stage of $0.199 \mathrm{ft}$ above NAVD 88 to release water to tide; when upstream stages are falling, the spillway begins to close at an upstream stage of $-0.210 \mathrm{ft}$ above NAVD 88 . The $\mathrm{S}-13$ pump is represented as a stage-discharge structure in the SWR1 process with a linear stage-discharge relationship, which begins to discharge to tide at an upstream stage of $0.7 \mathrm{ft}$ above NAVD 88 and reaches its maximum pumping rate of $540 \mathrm{ft}^{3} / \mathrm{s}$ at an upstream stage of $1.7 \mathrm{ft}$ above NAVD 88. For the low and intermediate sea-level rise scenarios, the spillway is the primary source of discharge (figs. 20A, B), 


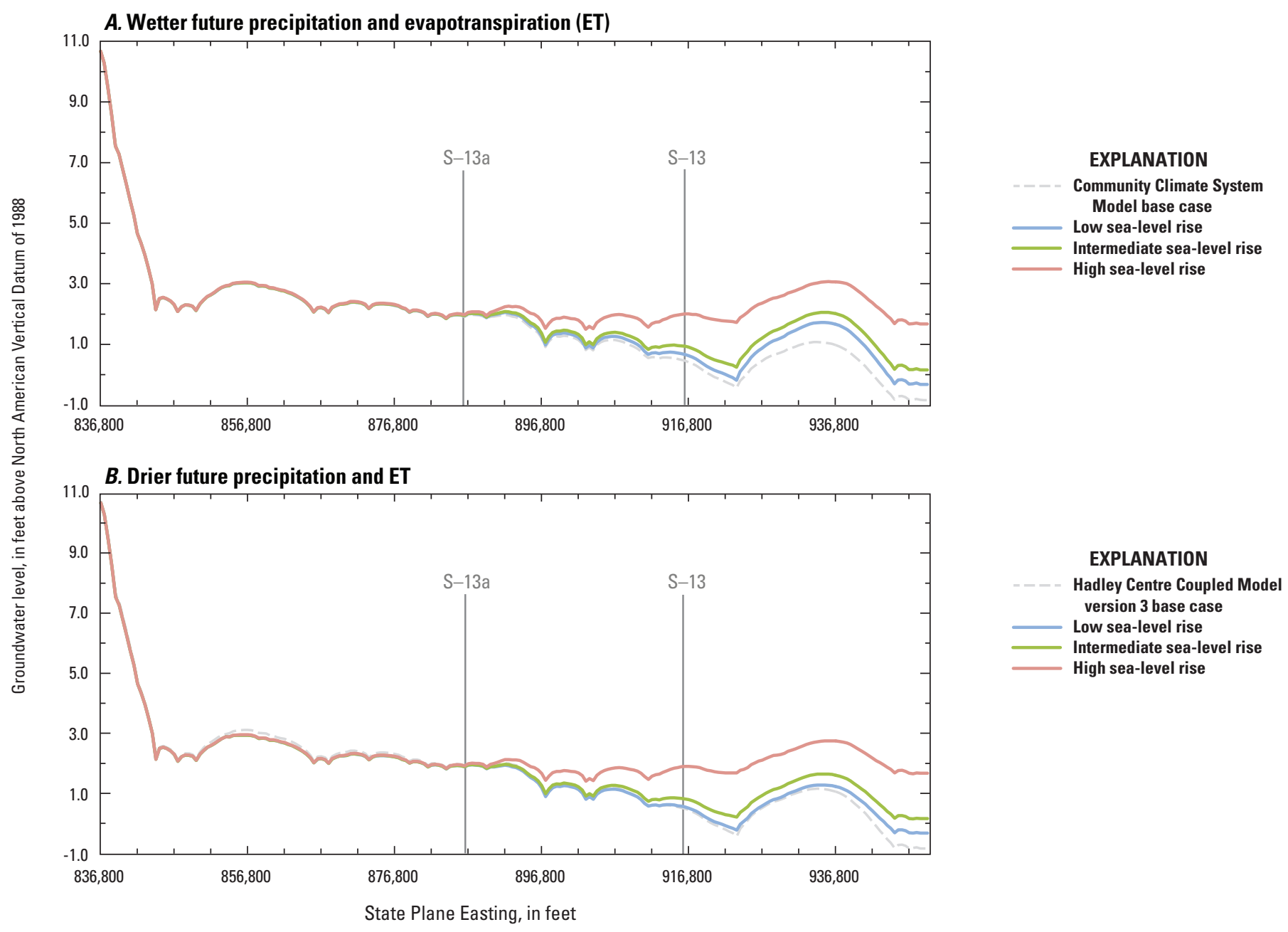

Figure 19. West-east continuous transect of average wet-season groundwater levels for base-case and wetter and drier future sea-level rise scenarios for 2060-69.

and the pump does not discharge. During these simulations, the upstream stage at $\mathrm{S}-13$ is similar to the base-case scenarios (figs. 21A, $B$ ).

For the high sea-level rise scenarios, operation of the S-13 spillway and pump structures changes notably from historical conditions as sea level rises. The elevated tidal levels increase the spillway's downstream stage and reduce the structure's capacity to discharge to the coast. With the high sea-level rise scenario average tidal level of $1.65 \mathrm{ft}$ above NAVD 88 during 2060-69, the spillway daily average downstream stage is nearly always greater than the upstream stage (fig. 21C), precluding discharge by gravity flow and requiring instead the $\mathrm{S}-13$ pump to discharge nearly all of the structure flow (fig. 20D). Under these conditions, the spillway is inoperable for large portions of the simulation period (figs. $20 C, D$; tables 7 and 8). When pumping is required to transport the majority of the $\mathrm{S}-13$ discharge because of the linear stage-discharge relationship that sets the pumping controls, the average upstream stages increase, resulting in higher canal and groundwater levels, as seen between the S-13a and S-13 structures in figure 19. For the high sea-level rise scenarios, the upstream stage at $\mathrm{S}-13$ becomes elevated by an average of $0.744 \mathrm{ft}$ for the wetter and $0.721 \mathrm{ft}$ for the drier future precipitation scenarios. In contrast to conditions at $\mathrm{S}-13$, the other primary active structures $(\mathrm{G}-54, \mathrm{~S}-33$, and S-9) maintain upstream levels similar to base-case scenarios for the high sea-level rise scenarios (fig. 22).

The effects of sea-level rise on groundwater levels within the eastern coastal part of the model area are further illustrated by evaluating the percentage of increased sea-level rise that is reflected in the increased average wet-season groundwater levels (figs. 23 and 24). For example, if wet-season groundwater levels reflected 100 percent of the average sea-level rise, groundwater levels would rise $0.514 \mathrm{ft}, 0.99 \mathrm{ft}$, and $2.49 \mathrm{ft}$ for the low, intermediate, and high sea-level rise scenarios, respectively. In contrast, if wet-season groundwater levels reflected 0 percent of sea-level rise for any scenario, groundwater levels would not rise at all. For all scenarios, the groundwater levels in coastal areas reflect increases nearly equivalent to sea-level rise, whereas in much of the simulated area away from the coast, groundwater levels do not reflect any effects of sea-level rise. The effect of sea-level 
A. S-13 Spillway, low sea-level rise
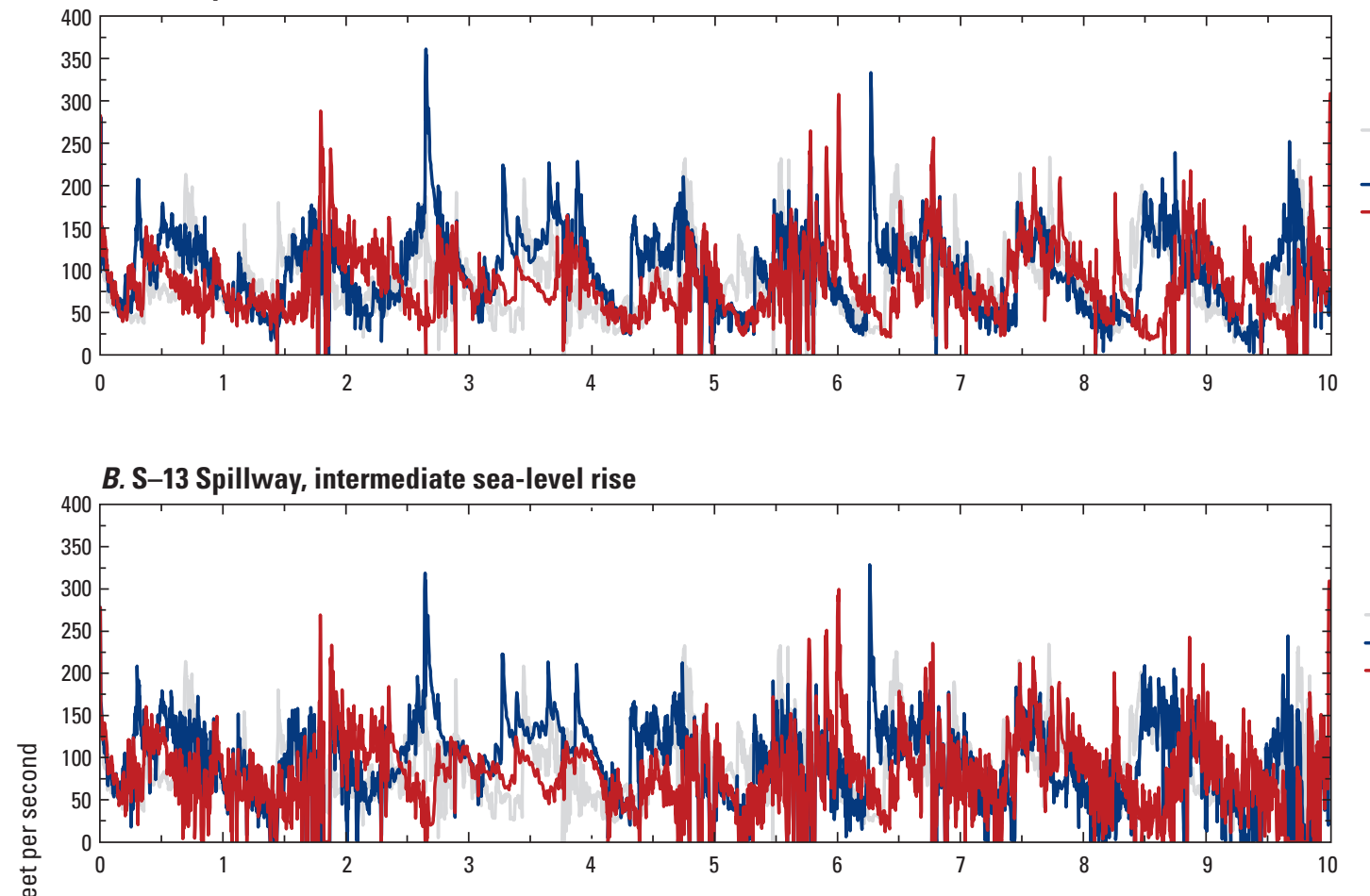

\section{S-13 Spillway, high sea-level rise}

은

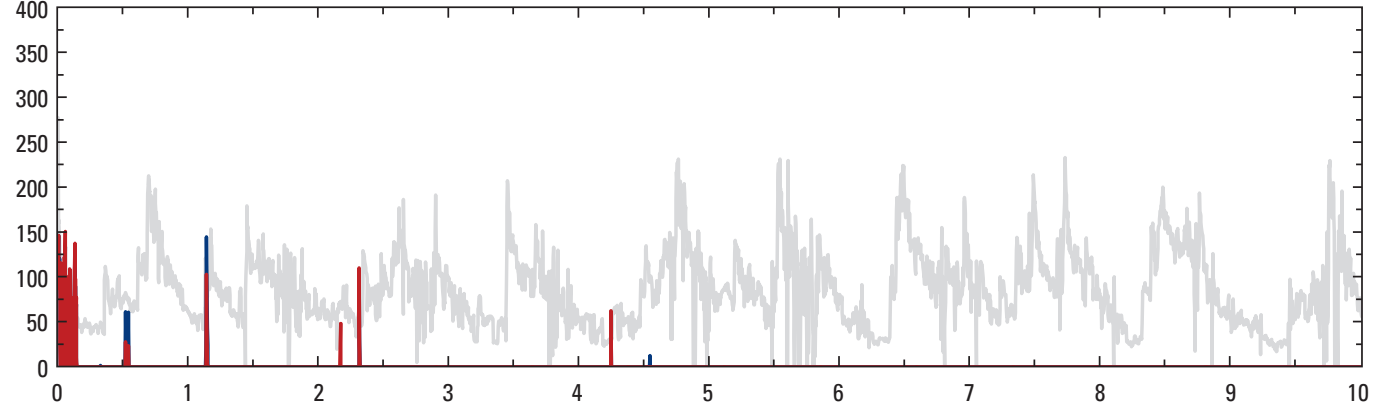

D. S-13 Pump, high sea-level rise

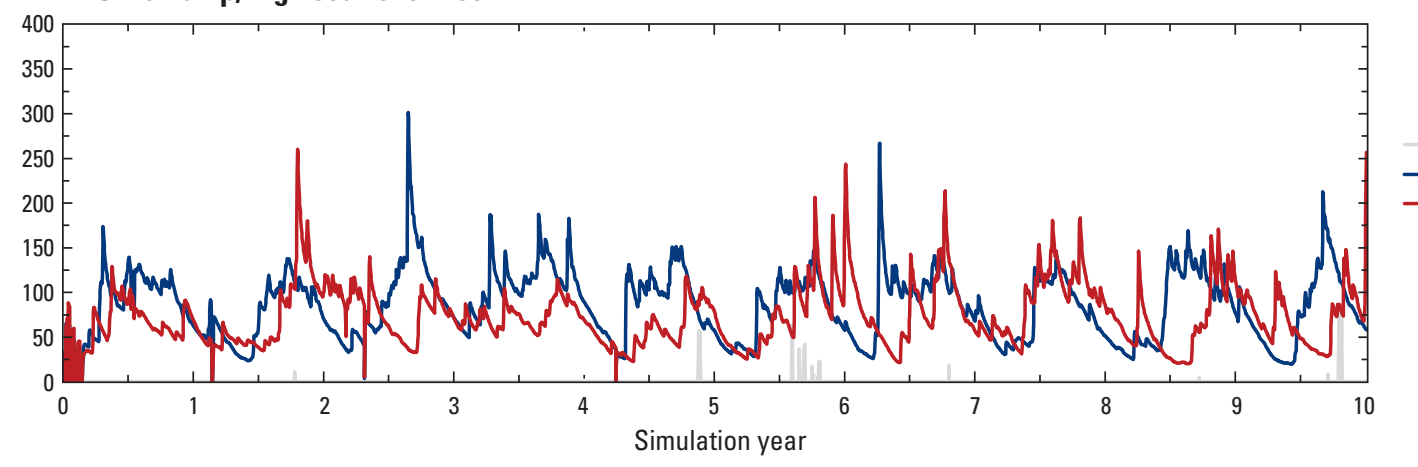

Figure 20. Structure $\mathrm{S}-13$ spillway flow, for $A$, low; $B$, intermediate; and $C$, high sea-level rise scenarios, and $D$, pump flow for the high sea-level rise scenarios for 1990-99 or 2060-69.
EXPLANATION

Community Climate System Model (CCSM) base case Wetter future

Drier future
EXPLANATION

CCSM base case Wetter future Drier future
EXPLANATION

CCSM base case

Wetter future

Drier future 


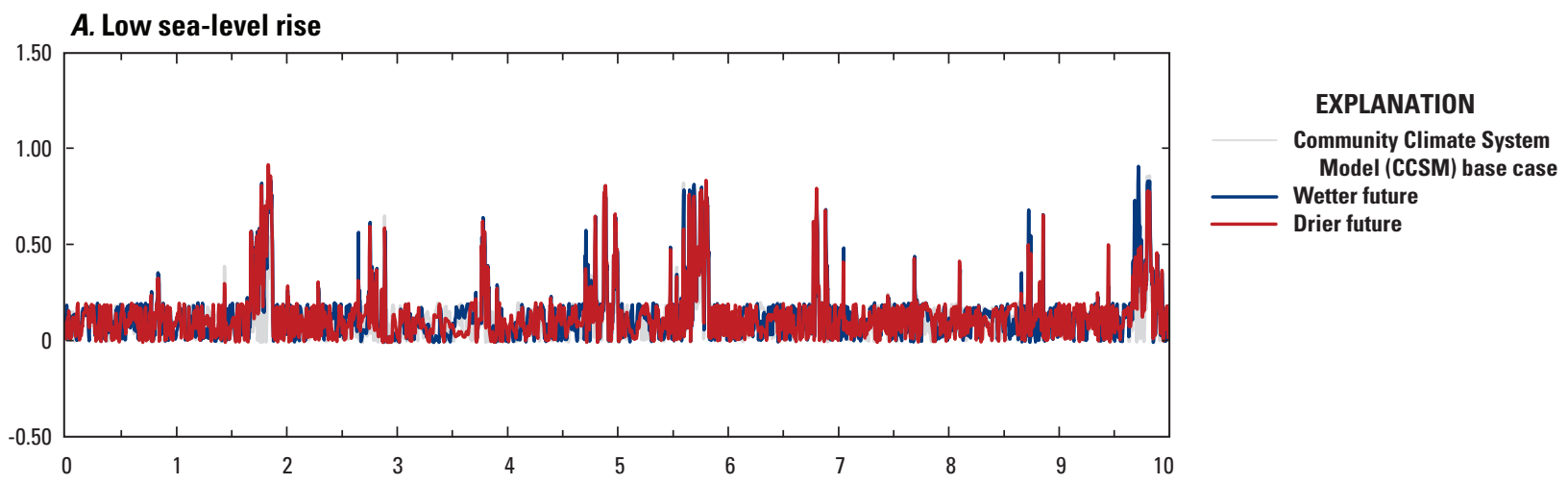

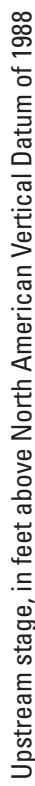

B. Intermediate sea-level rise

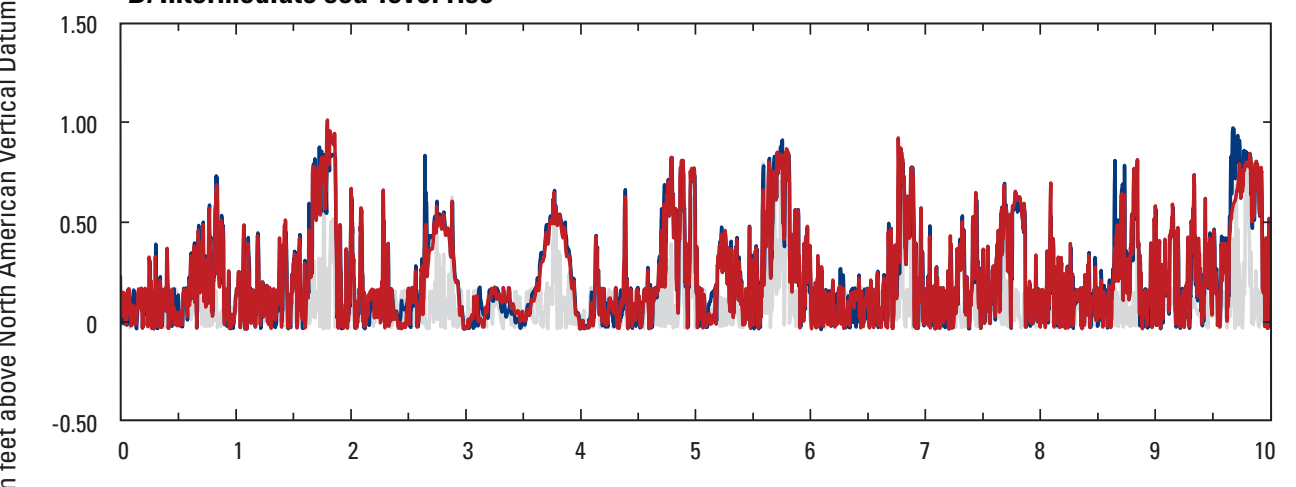

EXPLANATION

CCSM base case

Wetter future

Drier future

\section{High sea-level rise}

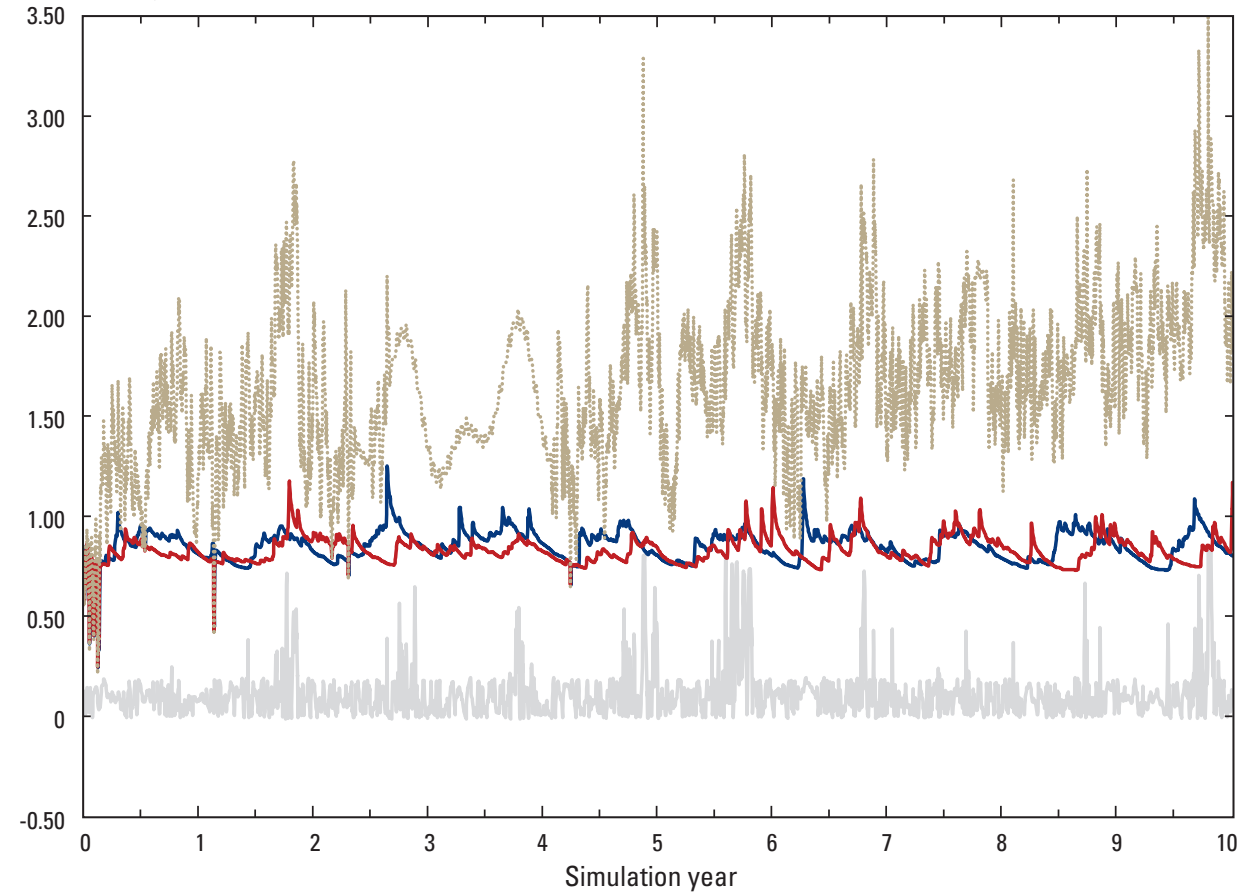

EXPLANATION

CCSM base case

Wetter future

Drier future

Daily tide

Figure 21. Upstream stage at structure $\mathrm{S}-13$ for $A$, low; $B$, intermediate; and $C$, high sea-level rise and wetter and drier future climate scenarios for 1990-99 or 2060-69. 


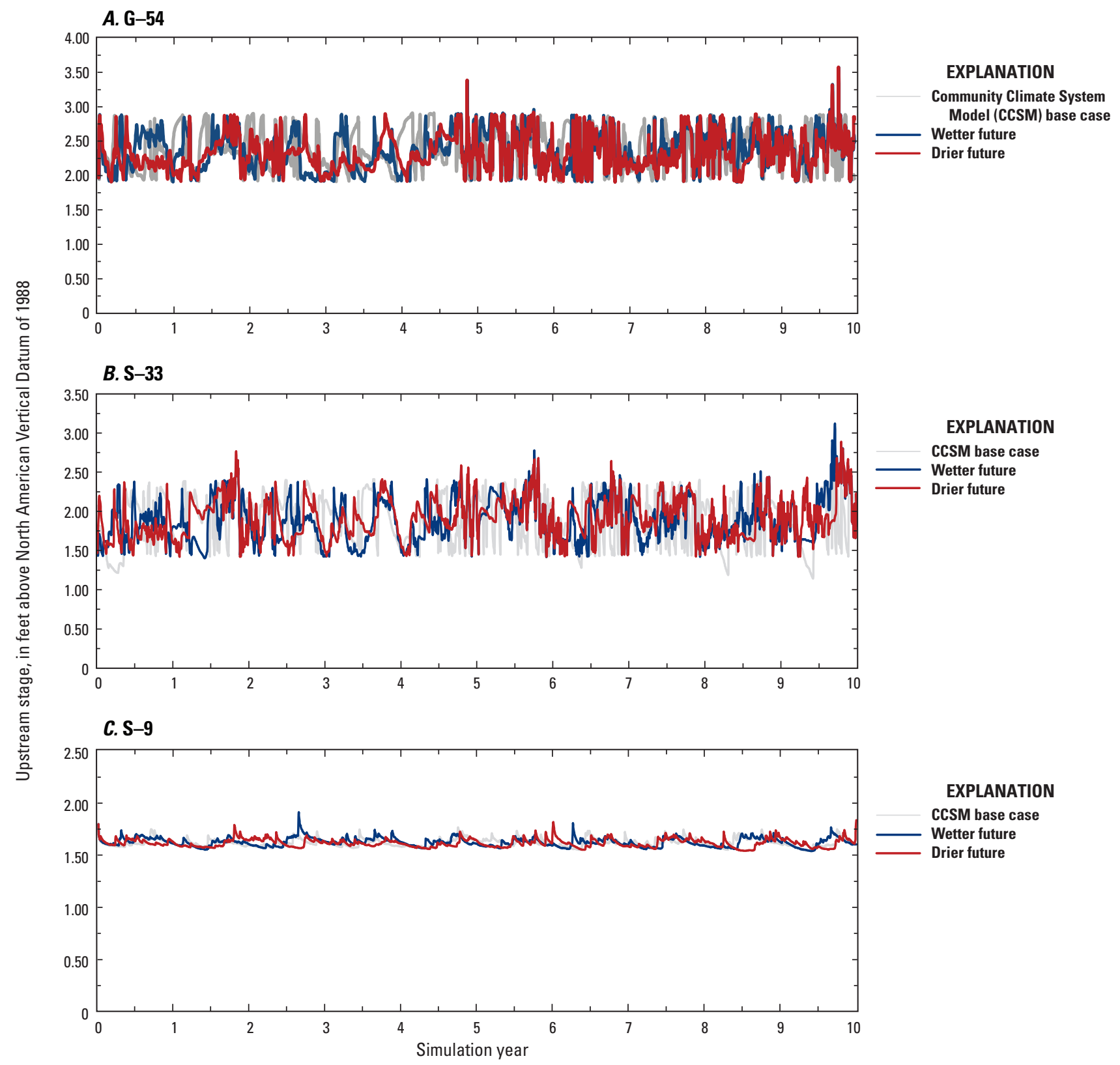

Figure 22. Upstream stage at primary structures $A, \mathrm{G}-54 ; B, \mathrm{~S}-33$; and $C, \mathrm{~S}-9$ for high sea-level rise and wetter and drier future climate scenarios for 1990-99 or 2060-69.

rise on groundwater levels for the drier future scenarios is less extensive (fig. 24) than for the wetter future scenarios (fig. 25) because of the relatively lower precipitation. The general northwest-to-southeast groundwater-level gradient within the model area persists for all scenarios, even with the average sea-level rise of $2.49 \mathrm{ft}$ from the high sea-level rise scenarios (fig. 25).

The coastal areas also exhibit the largest increase in extents of groundwater cells, with average wet-season depth to groundwater of less than $1 \mathrm{ft}$ because of sea-level rise and precipitation variations (fig. 26). These coastal areas have a much higher likelihood of becoming inundated during moderate precipitation events because of the shallow depth to groundwater. For the wetter future scenarios, the low sea-level rise simulation resulted in a $2.484-\mathrm{mi}^{2}(+3.0$ percent $)$ increase in inundated area; the intermediate simulation resulted in a $3.757-\mathrm{mi}^{2}$ ( +4.6 percent) increase; and the high simulation scenario resulted in a $12.106-\mathrm{mi}^{2}(+14.8$ percent $)$ increase in inundated coastal area. With the decreased precipitation in the drier future scenarios, the total area where the depth to groundwater was less than $1 \mathrm{ft}$ decreased by $3.085 \mathrm{mi}^{2}$ (-3.7 percent) and $1.668 \mathrm{mi}^{2}$ (-2.0 percent) for the low and intermediate sea-level rise scenarios, respectively, and increased by $5.69 \mathrm{mi}^{2}$ (+6.9 percent) for the high sea-level rise scenario. 
A. Wetter future, low sea-level rise

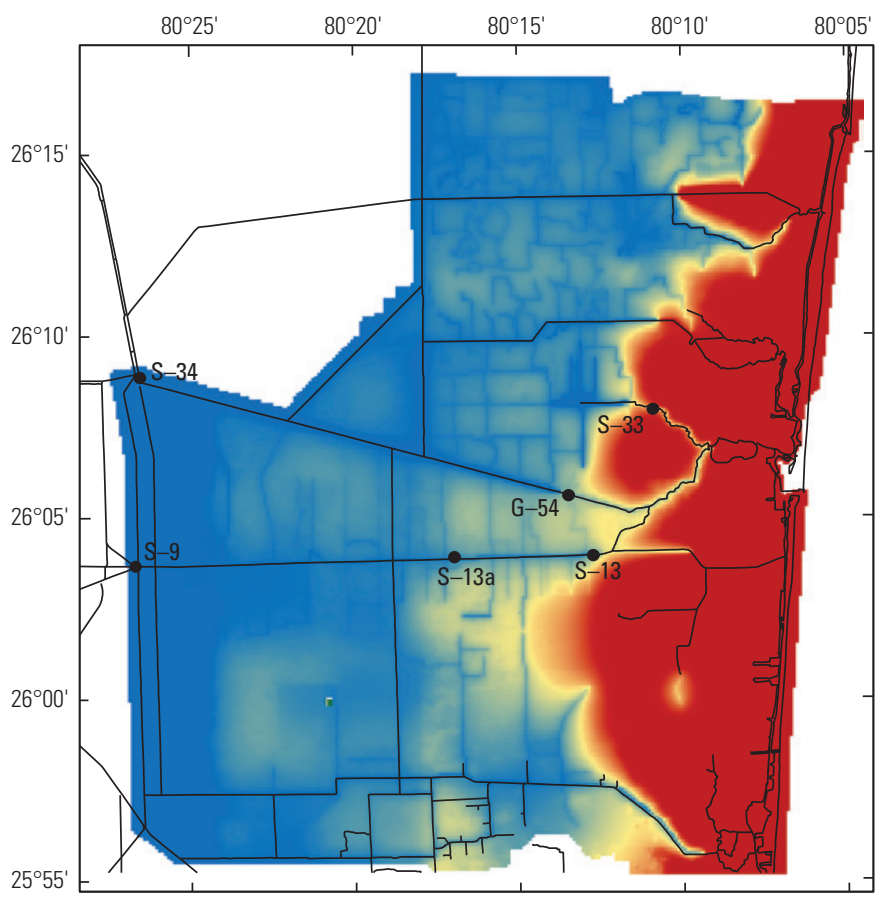

B. Wetter future, intermediate sea-level rise

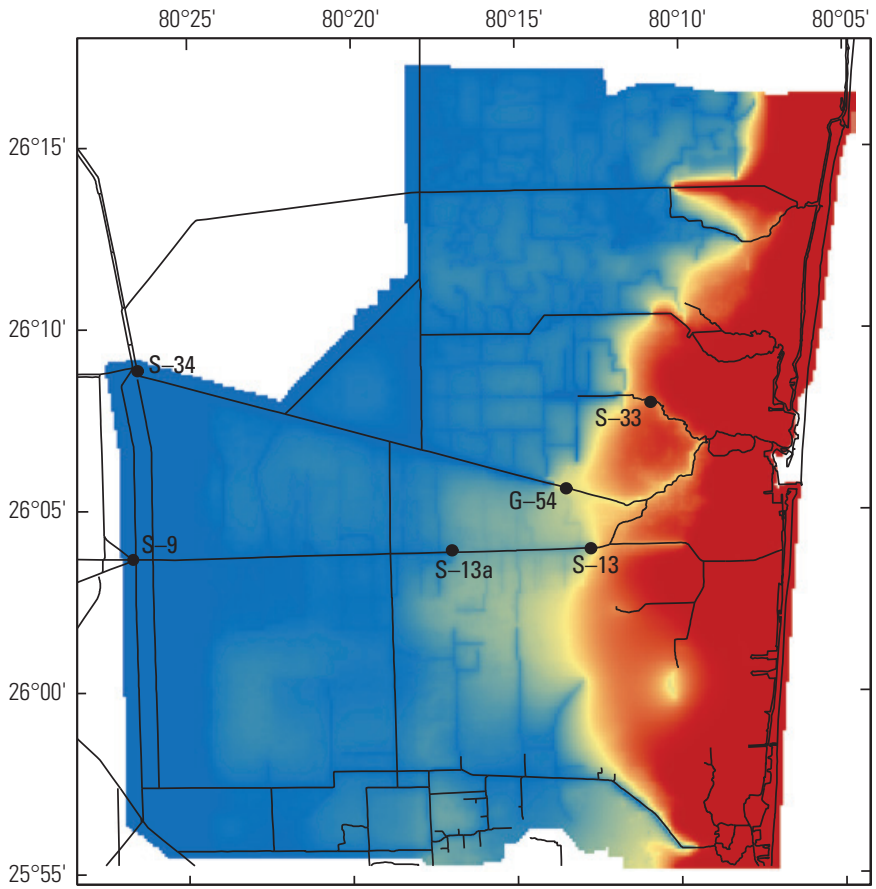

C. Wetter future, high sea-level rise

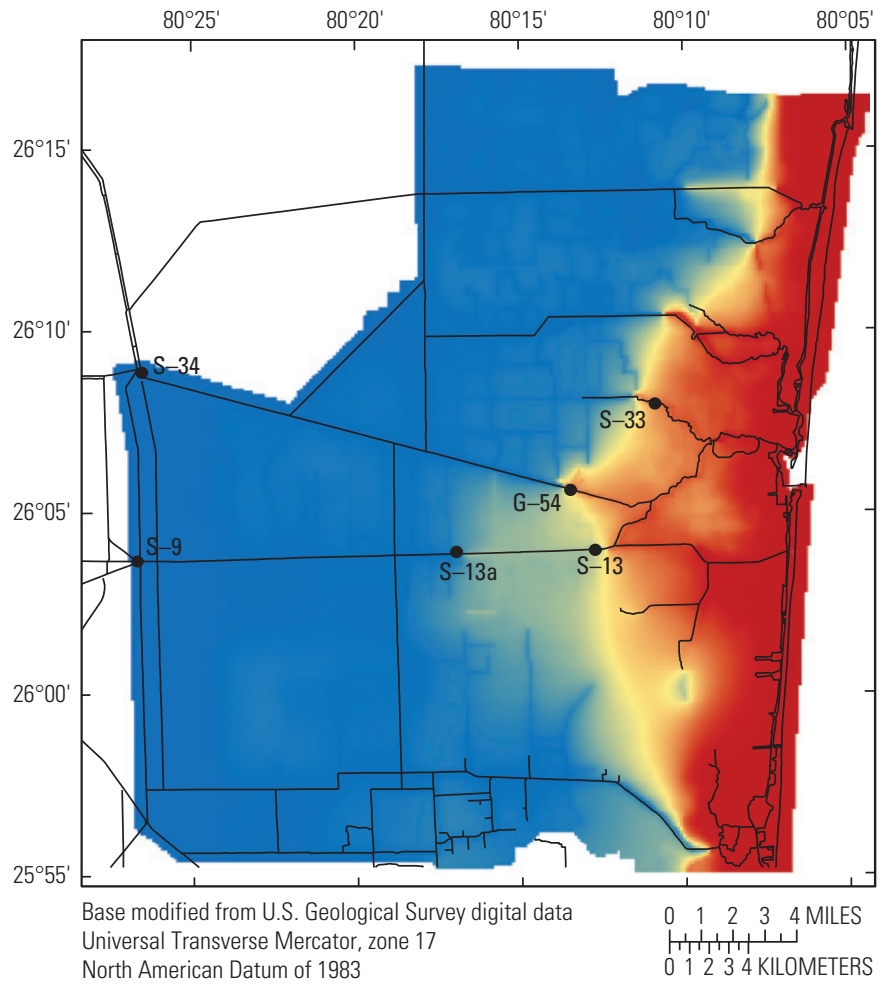

EXPLANATION

Percentage of sea-level rise

100

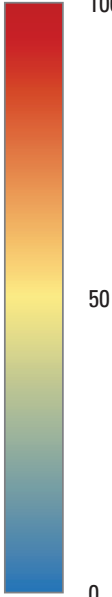

G-54 $\bullet$ Surface-water structure and identifier

Figure 23. Percentage of sea-level rise reflected in increased average wet-season groundwater levels for $A$, low sea-level rise; $B$, intermediate sea-level rise; and $C$, high sea-level rise, for wetter future climate scenarios within the county-scale model. 
A. Drier future, low sea-level rise

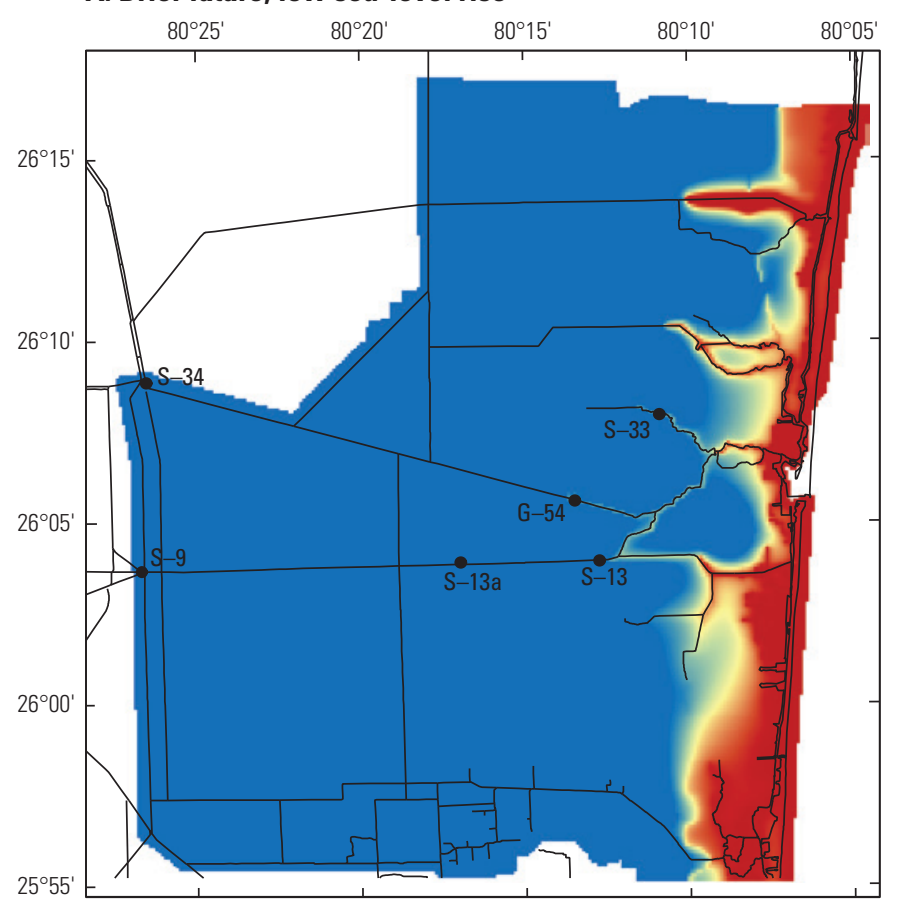

B. Drier future, intermediate sea-level rise

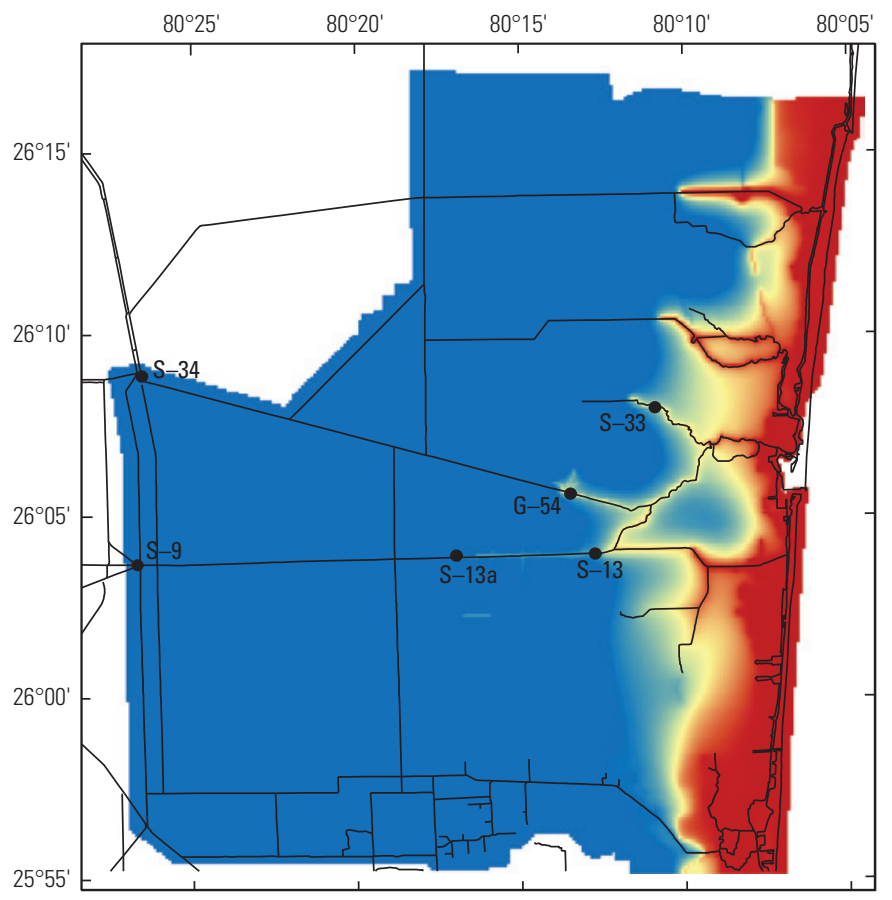

\section{Drier future, high sea-level rise}

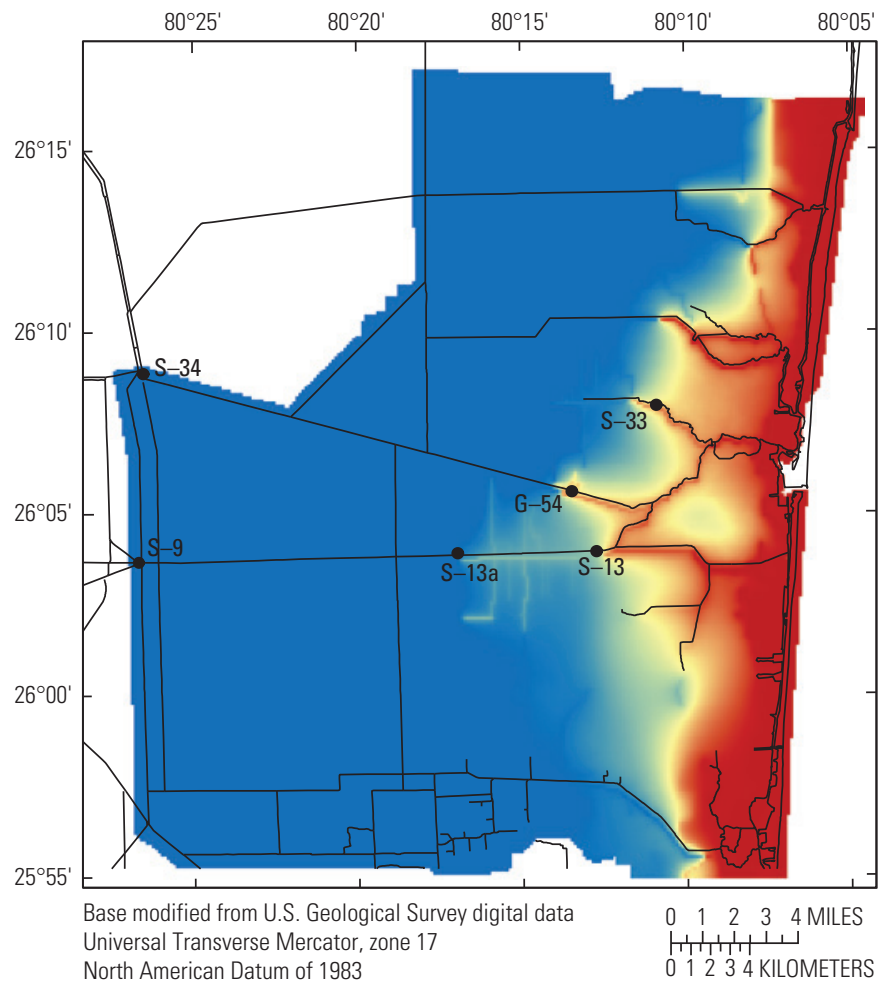

\section{EXPLANATION}

Percentage of sea-level rise

100

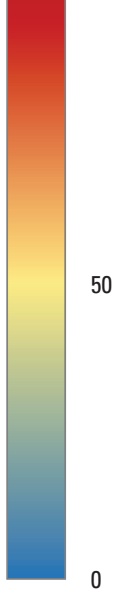

G-54 Surface-water structure and identifier

Figure 24. Percentage of sea-level rise reflected in increased average wet-season groundwater levels for $A$, low sea-level rise; $B$, intermediate sea-level rise; and $C$, high sea-level rise, for drier future climate scenarios within the county-scale model. 


\section{A. Community Climate System Model base case}

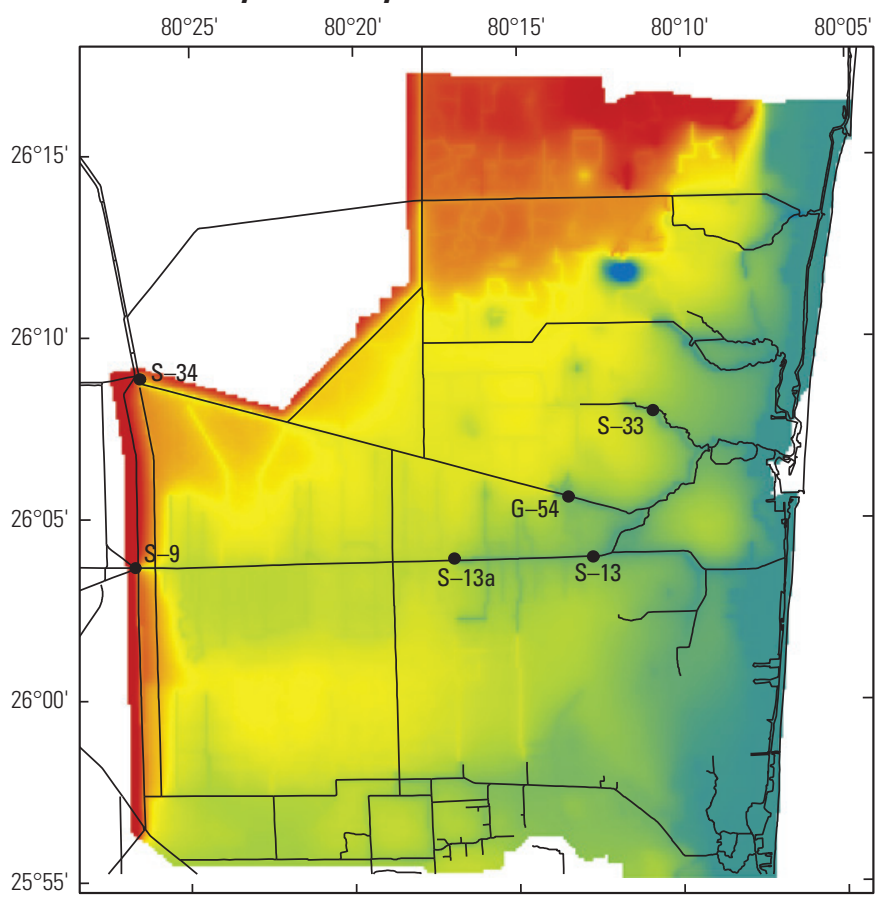

\section{B. Wetter future, high sea-level rise}

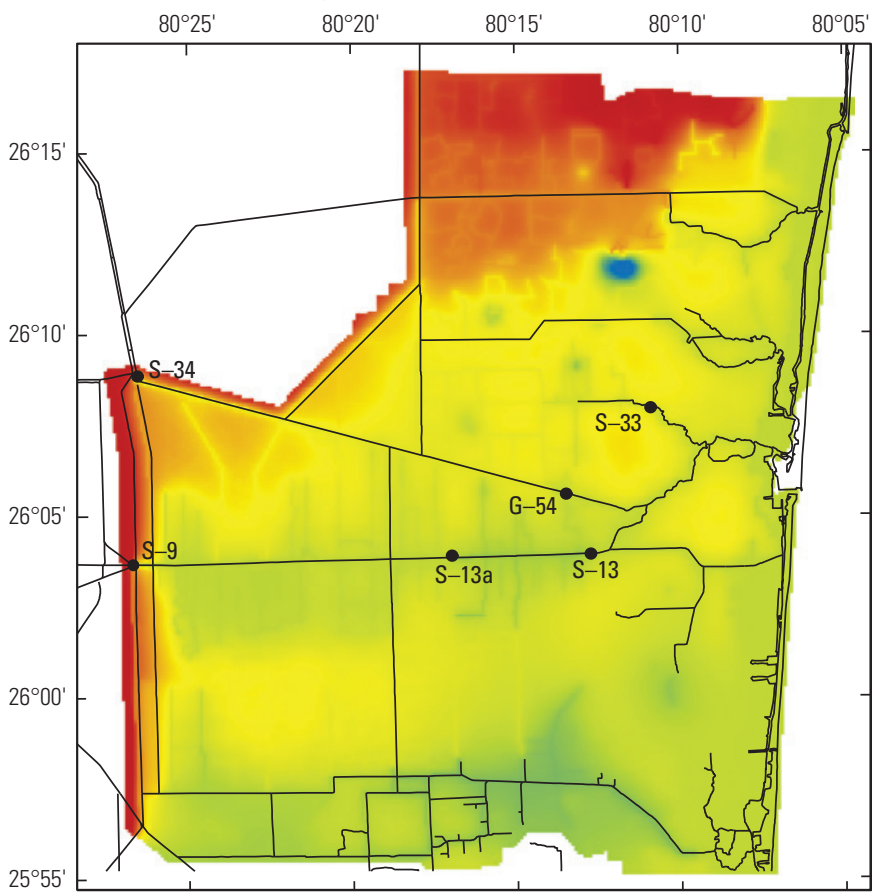

\section{Drier future, high sea-level rise}

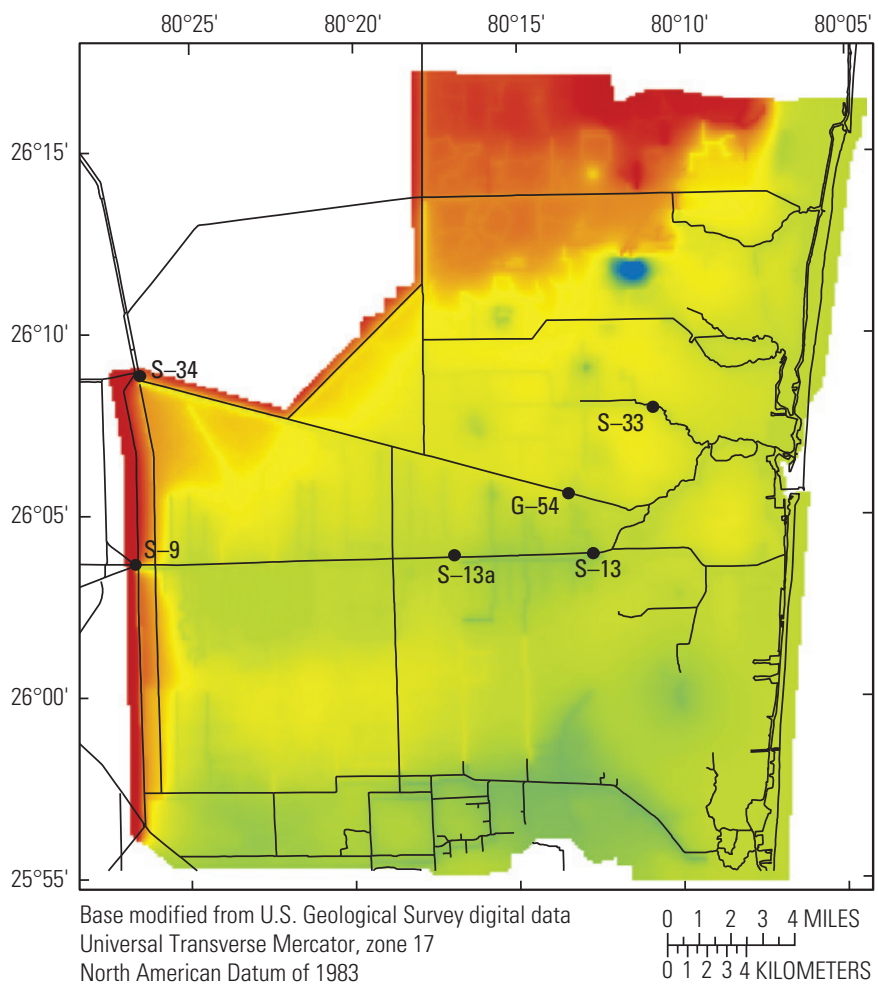

\section{EXPLANATION}

Groundwater level, in feet above North American Vertical Datum of 1988

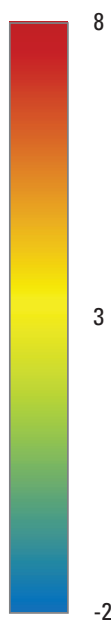

G-54 Surface-water structure and identifier

Figure 25. Average wet-season groundwater levels within the county-scale model for $A$, Community Climate Systems Model base case; $B$, wetter future, high sea-level rise; and $C$, drier future, high sea-level rise, future scenarios. 
A. Community Climate System Model base case

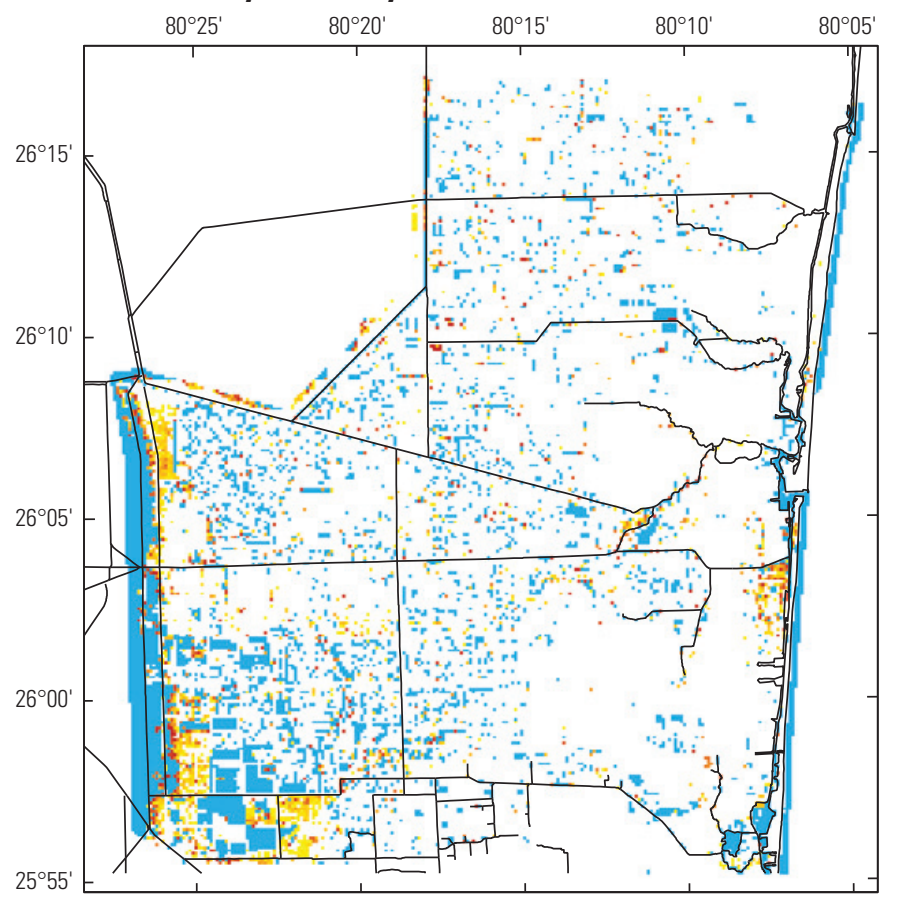

Base modified from U.S. Geological Survey digital data Universal Transverse Mercator, zone 17 North American Datum of 1983

\section{$B$. Wetter future, high sea-level rise}

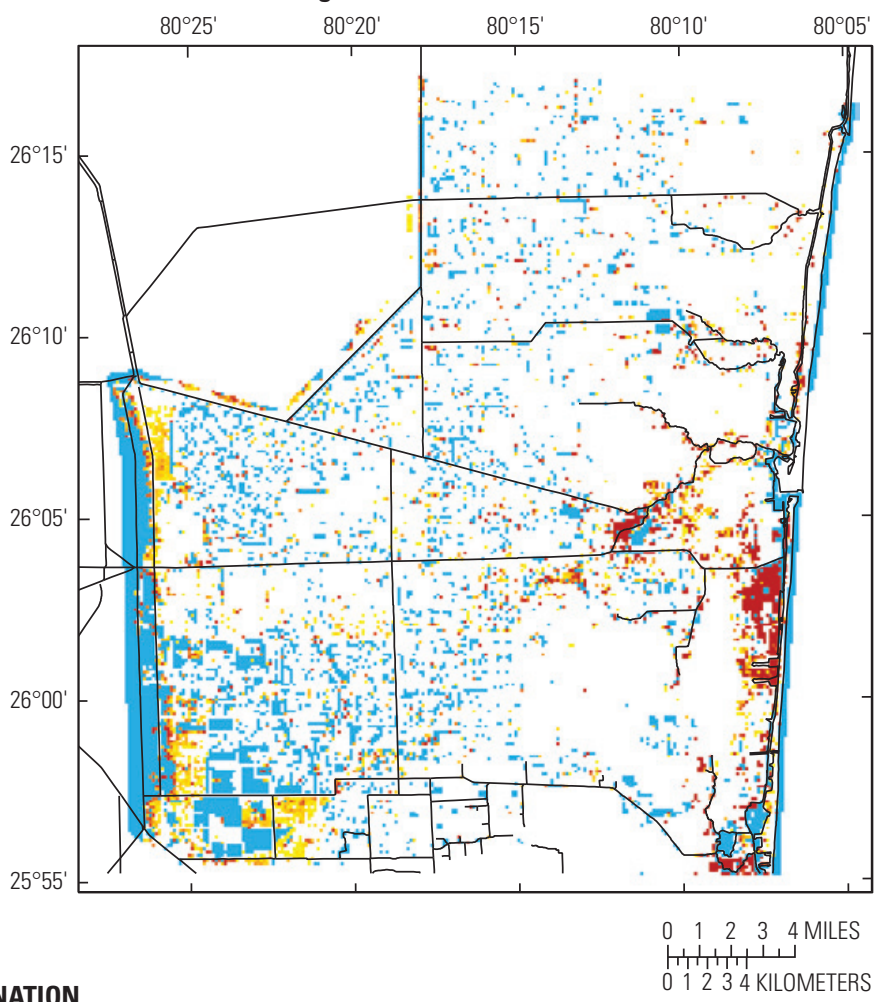

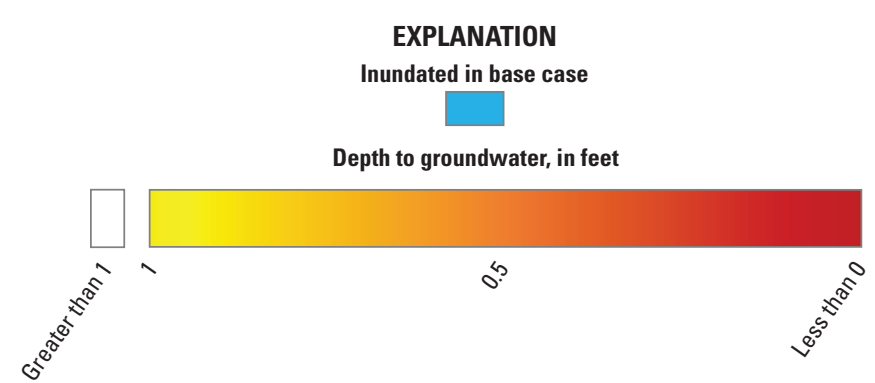

Figure 26. Average wet-season depth to groundwater for base-case, $A$, and the wetter future high sea-level rise, $B$, scenarios within the county-scale model.

\section{Local-Scale Model Scenario Results}

The scenarios representing future conditions that were applied to the county-scale model were also applied to the local-scale model. These conditions included combinations of low, intermediate, and high sea-level rise rates and wetter and drier future climate conditions. The local-scale model's results are more spatially refined with 166.7 -ft grid spacing compared to the 500 -ft grid spacing used for the county-scale model. Additionally, the local-scale model uses the SWR1 process time step of 10 minutes, compared to the 15 minutes used in the county-scale model, and uses hourly tidal-level data instead of the daily averaged tidal levels used in the county-scale model. Differences in average wet-season groundwater levels, primary structure flows, and increases in groundwater levels were used to evaluate the effects of potential climate conditions and sea-level rise on the hydrologic system.

\section{Comparison of Base-Case Climate Scenarios to the Historical Simulation}

Local-scale, model-simulated base-case groundwater levels and structure flow rates deviate more from the historical scenario results than results from the county-scale model. For the three groundwater-observation locations in the localscale model, the simulated mean base-case groundwater level was $0.379 \mathrm{ft}$ and $0.339 \mathrm{ft}$ lower for the CCSM and HadCM3 scenarios, respectively, than for the historical simulation (table 9). Similarly, the mean simulated flow rates through the G-54 and S-13 (spillway) structures were $23.0 \mathrm{ft}^{3} / \mathrm{s}$ and $19.1 \mathrm{ft}^{3} / \mathrm{s}$ lower for the CCSM and HadCM3 scenarios, respectively, compared to the historical simulation. The time-series results from the local-scale base-case scenarios for both groundwater levels and structure flow have similar peaks and trends when compared to the results from the historical 
Table 9. Groundwater levels and primary structure flow and changes for historical and base-case Community Climate System Model (CCSM) and Hadley Centre Coupled Model version 3 (HadCM3) simulations for the local-scale model.

[Positive values indicate an increase in groundwater levels and flows from historical simulation. ft, foot; CCSM, Community Climate System Model; HadCM3, Hadley Centre Coupled Model version 3; $\mathrm{ft}^{3} / \mathrm{s}$, cubic foot per second]

\begin{tabular}{|c|c|c|c|}
\hline Station name & $\begin{array}{c}\text { Historical } \\
\text { simulation } \\
\text { mean ground- } \\
\text { water level } \\
\text { (ft) }\end{array}$ & $\begin{array}{c}\text { CCSM } \\
\text { Base-Case } \\
\text { mean differ- } \\
\text { ence } \\
\text { (ft) }\end{array}$ & $\begin{array}{c}\text { HadCM3 } \\
\text { Base-Case } \\
\text { mean differ- } \\
\text { ence } \\
\text { (ft) }\end{array}$ \\
\hline $\mathrm{G}-617$ & 2.318 & -0.261 & -0.222 \\
\hline G-1221 & 1.244 & -0.505 & -0.474 \\
\hline $\mathrm{G}-561$ & 0.527 & -0.372 & -0.322 \\
\hline Mean & 1.363 & -0.379 & -0.339 \\
\hline Structure & $\begin{array}{c}\text { Historical } \\
\text { simulation } \\
\text { mean flow } \\
\left(\mathrm{ft}^{3} / \mathrm{s}\right)\end{array}$ & $\begin{array}{c}\text { CCSM } \\
\text { Base-Case } \\
\text { mean differ- } \\
\text { ence } \\
\left(\mathrm{ft}^{3} / \mathrm{s}\right)\end{array}$ & $\begin{array}{c}\text { HadCM3 } \\
\text { Base-Case } \\
\text { mean differ- } \\
\text { ence } \\
\left(\mathrm{ft}^{3} / \mathrm{s}\right)\end{array}$ \\
\hline G-54 & 317.9 & -23.9 & -18.8 \\
\hline S-13 (spillway) & 107.8 & -22.0 & -19.3 \\
\hline Mean & 212.8 & -23.0 & -19.1 \\
\hline
\end{tabular}

scenario and the corresponding county-scale base-case scenarios. These differences are likely associated with the increased resolution within the groundwater model and increased density in SWR1-represented surface-water features.

\section{Comparison of Sea-Level Rise and Wetter or Drier Future Scenarios With Base-Case Scenarios}

Similar to the results from the county-scale model, simulation results from the local-scale models show that the largest effects on groundwater levels caused by changes in sea-level rise and precipitation occur in areas closest to the coast. In the wetter future climate scenarios for the local-scale model, the mean precipitation increased 18.8 percent from $56.9 \mathrm{in} / \mathrm{yr}$ during the 1990-99 CCSM Base-Case scenario to $67.6 \mathrm{in} / \mathrm{yr}$ during the 2060-69 future simulation period. This increase in precipitation, coupled with increased sea level, resulted in average groundwater-level increases of $0.710 \mathrm{ft}$, $1.133 \mathrm{ft}$, and $2.423 \mathrm{ft}$ at the easternmost groundwater station location, G-561, for the low, intermediate, and high sea-level rise scenarios, respectively. The westernmost groundwater well, G-617, displayed minimal increases of $0.037 \mathrm{ft}, 0.034 \mathrm{ft}$, and $0.036 \mathrm{ft}$ for the low, intermediate, and high sea-level rise scenarios, respectively, whereas the centrally located well, $\mathrm{G}-1221$, exhibited increases of $0.238 \mathrm{ft}, 0.397 \mathrm{ft}$, and $1.074 \mathrm{ft}$ for the same scenarios, respectively (table 10).
In the drier future climate scenarios for the local-scale area, precipitation decreased 7.0 percent from $58.6 \mathrm{in} / \mathrm{yr}$ during the 1990-99 HadCM3 Base-Case scenario to $54.5 \mathrm{in} / \mathrm{yr}$ during the 2060-69 future simulation period. The decrease in precipitation, coupled with increasing sea level, resulted in increasing groundwater levels in the easternmost well, G-561, by $0.345 \mathrm{ft}, 0.777 \mathrm{ft}$, and $2.103 \mathrm{ft}$ for the low, intermediate, and high sea-level rise scenarios, respectively. Simulated groundwater levels decreased at the westernmost well, G-617, relative to the baseline simulation by $0.116 \mathrm{ft}, 0.121 \mathrm{ft}$, and $0.121 \mathrm{ft}$ for the low, intermediate, and high sea-level rise scenarios, respectively. Simulated groundwater levels at well G-1221 increased relative to the baseline simulation by $0.048 \mathrm{ft}, 0.205 \mathrm{ft}$, and $0.898 \mathrm{ft}$ for the low, intermediate, and high sea-level rise scenarios, respectively (table 10 ).

The upstream stage at structure G-54 was maintained within the same gate-operating range of 2.899 to $1.899 \mathrm{ft}$ above NAVD 88 for all wetter and drier future scenarios, as was maintained in both base-case scenarios. For the wetter future scenarios, the MD in the mean flow through the G-54 structure was $11.8 \mathrm{ft}^{3} / \mathrm{s}, 14.9 \mathrm{ft}^{3} / \mathrm{s}$, and $21.4 \mathrm{ft}^{3} / \mathrm{s}$ for the low, intermediate, and high sea-level rise scenarios, respectively. For the drier future scenarios, the MD in the mean flow through the G-54 structure was $-7.5 \mathrm{ft}^{3} / \mathrm{s},-4.8 \mathrm{ft}^{3} / \mathrm{s}$, and $3.6 \mathrm{ft}^{3} / \mathrm{s}$ for the low, intermediate, and high sea-level rise scenarios (table 10).

In contrast, the upstream stage and flow rates at structure S-13 change substantially at different sea levels in the future scenarios, compared to the small differences in upstream stage and flow rates at structure G-54 (fig. 27). The future scenarios result in higher and more frequent peaks in upstream stages at structure $\mathrm{S}-13$ than those seen in the base-case scenarios as the downstream stages increase with the low, intermediate, and high sea-level rise scenarios (figs. $27 B, C$ ). For the high sealevel rise future scenarios, the upstream stage is consistently above base-case scenario stages, with average increases of $0.693 \mathrm{ft}$ and $0.671 \mathrm{ft}$ for the wetter and drier future scenarios, respectively (figs. $27 B, C$ ). The $\mathrm{S}-13$ pump rarely operates in the base-case scenarios, and there are only marginal increases for the low and intermediate sea-level rise scenarios (table 10). In the high sea-level rise scenarios, there is a shift to rely more on the S-13 pump than the spillway, with 71.2 percent of the structure flow being pumped in the wetter scenario and 68.7 percent being pumped in the drier scenario. This is less reliance on the pump than required in the county-scale model, which was 99 percent for the wetter and drier high sea-level rise future scenarios. The difference can be attributed to the temporal resolution of the tidal stage inputs used in the county- and local-scale simulations. The county-scale model uses daily tidal stage values, whereas the local-scale model uses hourly tidal stage values. During the daily low tide periods of the local-scale model, the spillway can operate if the downstream stage falls below the upstream stage, which does not occur when using averaged daily tidal stages. As the average tidal stage levels continue to increase throughout the high sea-level rise simulation, the number of times when the 
Table 10. Simulated groundwater levels and primary structure flows and mean differences in groundwater levels and primary structure flows for climate and sea-level rise scenarios using the local-scale model.

[Positive values indicate an increase in groundwater levels and flows from the base-case simulation. CCSM, Community Climate System Model; ft, foot; ftºs, cubic foot per second; HadCM3, Hadley Centre Coupled Model version 3]

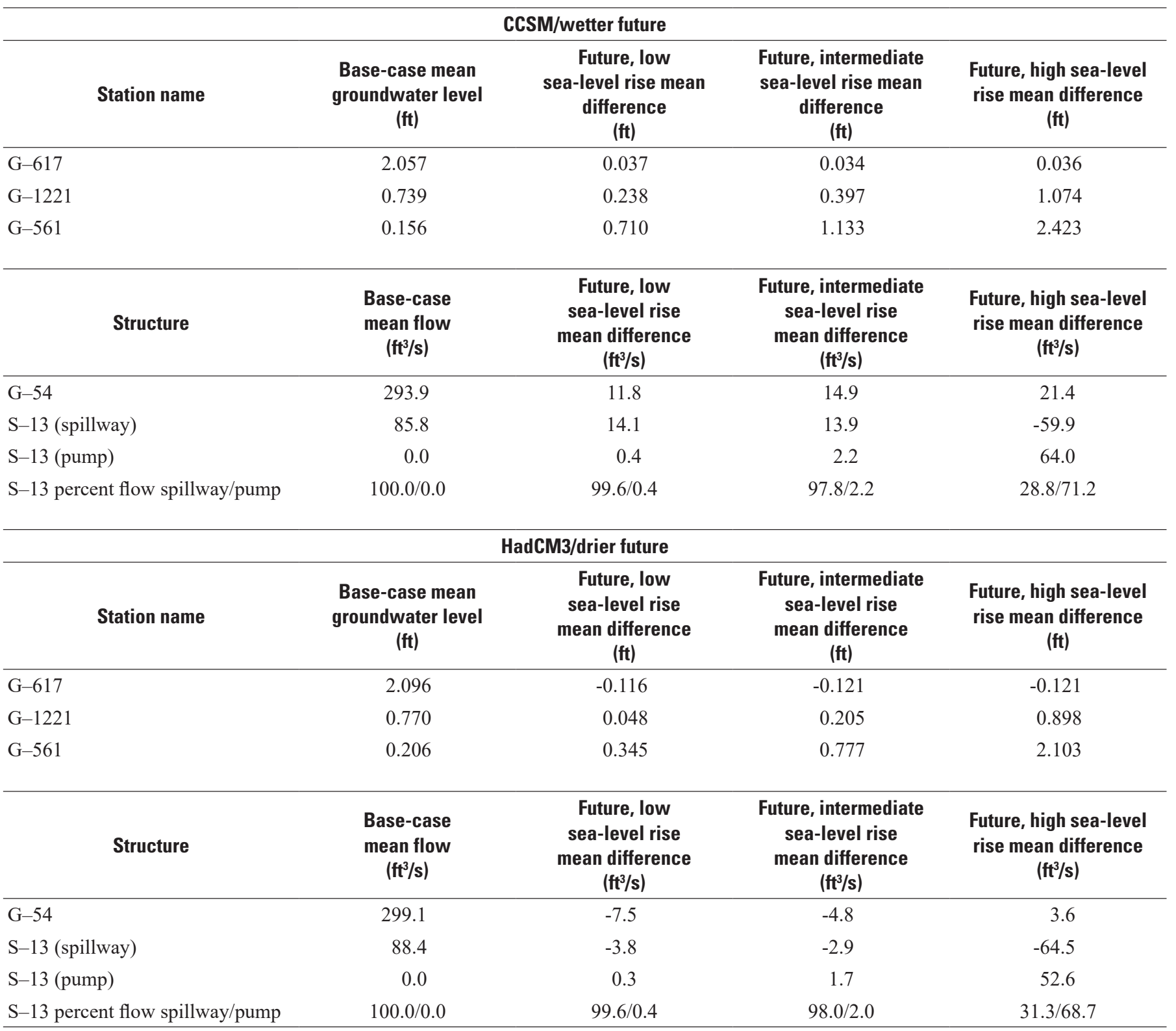

downstream stage falls below the upstream stage decreases, and there is more reliance on the pump (fig. 28). As in the county-scale model, the stage-discharge curve representing the pump causes the upstream stage to increase when the spillway is no longer able to operate.

The increased precipitation for the wetter future scenarios has a substantial effect on the increased average wet-season groundwater levels for the three sea-level rise scenarios (fig. 29). Compared to the drier future scenarios results (fig. 30), the average wet-season groundwater-level maps indicate increased mounding of water in interior areas between surface-water features, as well as higher overall groundwater levels. While some interior areas of the eastern part of the model area have only minor increases in groundwater levels for the drier future low and intermediate sea-level rise scenarios, the wetter future model results indicate groundwater-level increases that are greater than the increases in sea level. The results from the drier scenarios show less interior mounding (fig. 30). Despite these differences, the groundwater-level maps exhibit the same general patterns for each scenario: increases in groundwater levels near the coast are nearly equal to the sea-level rise; groundwater tends to mound in areas between surface-water features, such as canals, and this becomes more pronounced in the wetter future 


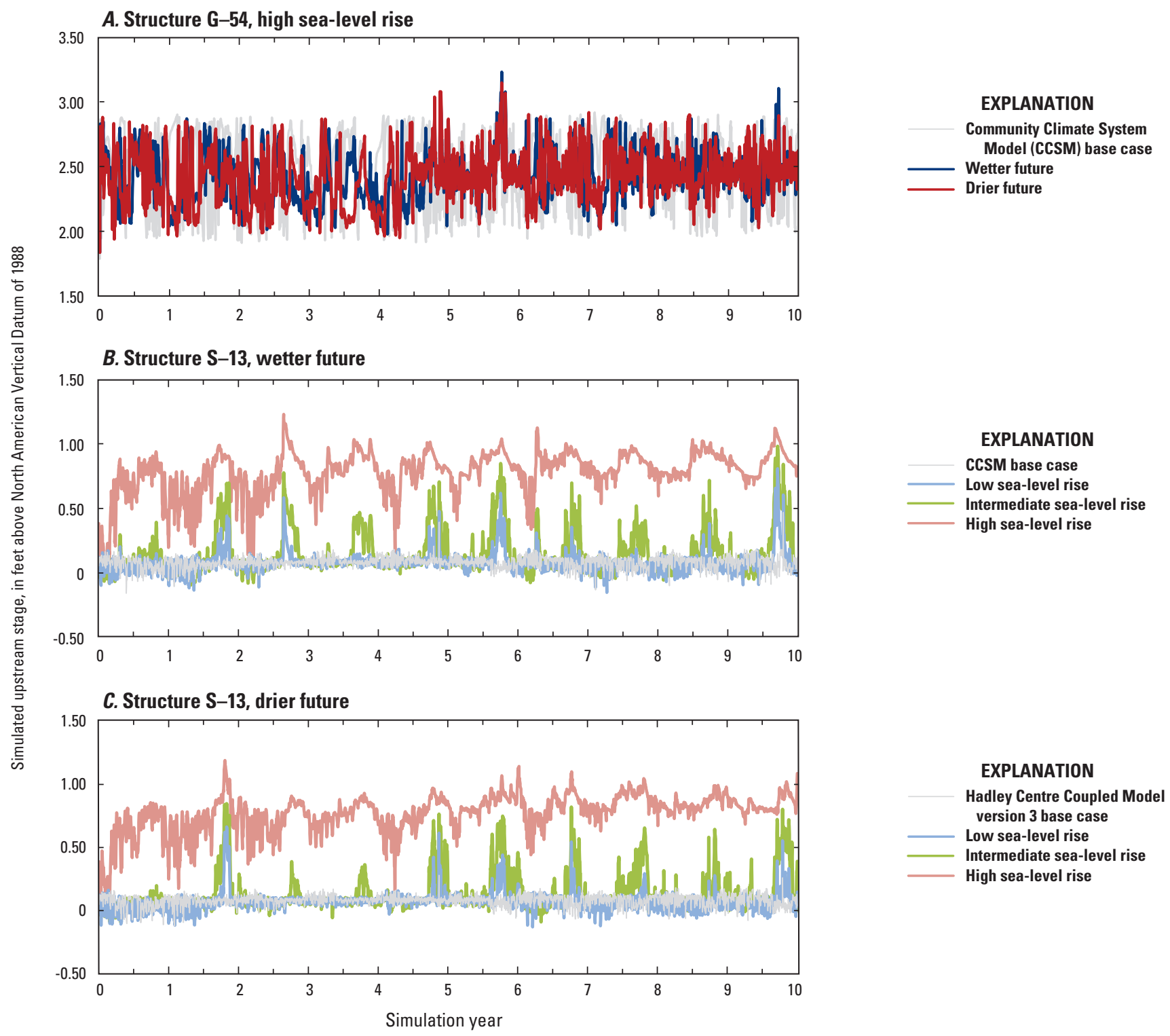

Figure 27. Simulated upstream stage at the $A, \mathrm{G}-54$; and $B, C$, $S-13$ structures for future climate and sea-level rise scenarios for the localscale model for 1990-99 or 2060-69.

scenarios; and groundwater increases less in the western part of the model than in the eastern part. Pump operations at S-13 effectively lower the groundwater levels between the S-13 and S-13a structures for the high sea levels and limit the groundwater increases in the western part of the model (figs. 29, 30, and 31).

The average wet-season depths to groundwater for each of the local-scale model future scenarios indicate a larger area of potential inundation in the eastern model area relative to the western part (fig. 32), as was shown by using results from the county-scale model (fig. 26). For the CCSM scenarios, the current rate of sea-level rise simulation had an increased area of $1.33 \mathrm{mi}^{2}(+12.0$ percent $)$ with a water table of less than $1 \mathrm{ft}$, whereas the NRC Curve I and NRC Curve III simulations had increased areas of $2.13 \mathrm{mi}^{2}(+13.0$ percent $)$ and $5.79 \mathrm{mi}^{2}$ (+14.0 percent).

\section{Simulation of Hypothetical Mitigation Strategies}

The results of this study indicate that projected future climate change and, in particular, sea-level rise will increase groundwater levels in Broward County, with the largest increases occurring along the eastern coastline and diminishing inland. Because of the highly permeable aquifer, shallow depths to the water table, and flat groundwater gradients, the projected rise in sea level will contribute to widespread increases in groundwater levels and will exacerbate the challenges of adapting to or mitigating the negative effects of sea-level rise and climate change. The increased groundwater levels exhibited in the various future scenarios result in newly inundated areas and increase the 


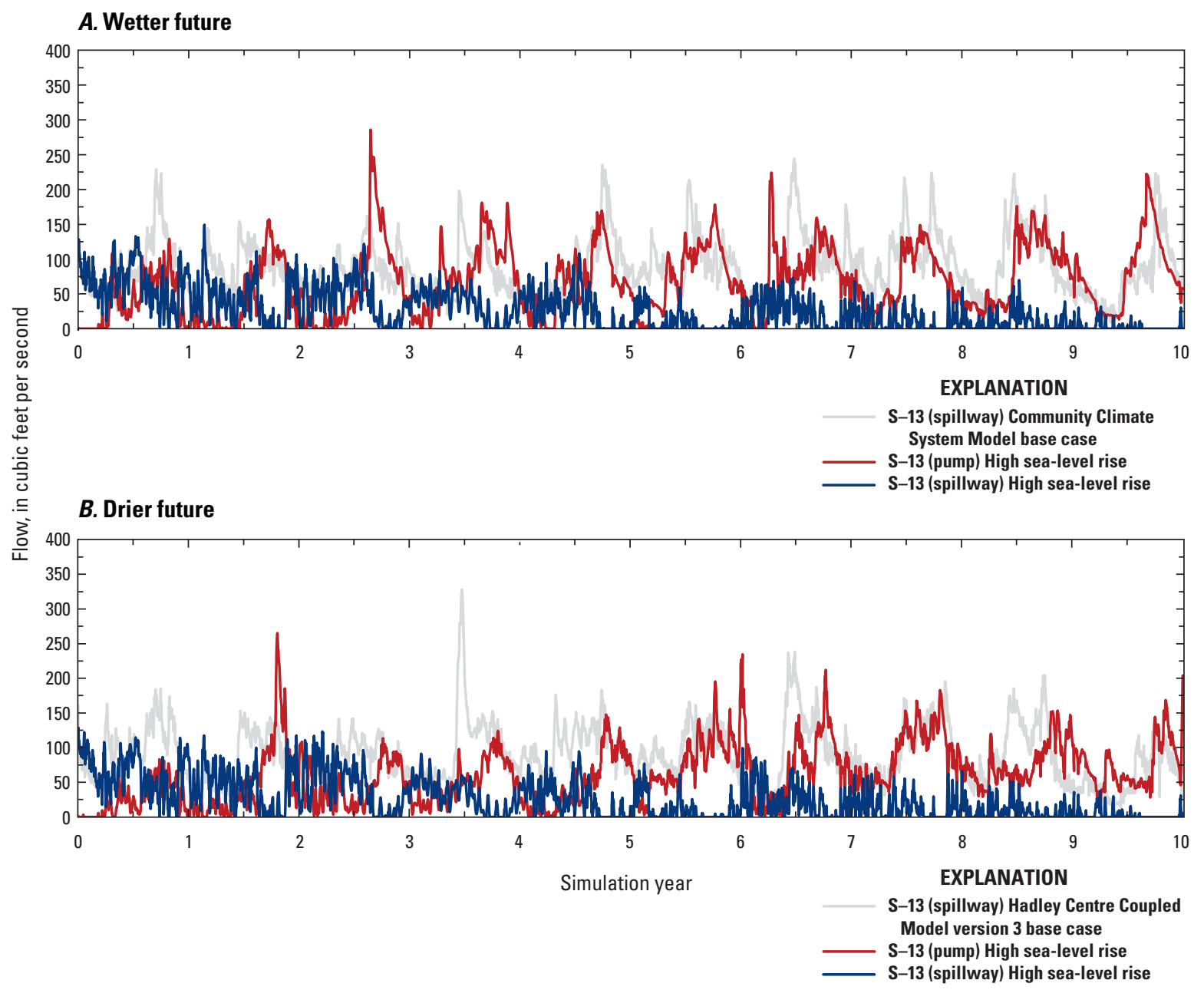

Figure 28. Spillway and pump flow for structure $S-13$ for $A$, wetter future, and $B$, drier future climate and sea-level rise scenarios for the local-scale model for 1990-99 or 2060-69.

areal extent of flood-prone lands because of reduced soil storage capacity. Possible mitigation strategies include alterations to coastal structure operations or locations, changes to building foundation and roadway elevation requirements, and neighborhood-scale flood control using pumps. Using the local-scale and county-scale models, scenarios using these types of mitigation strategies were simulated with the primary goal of maintaining historical simulation groundwater levels.

\section{Adapting Pumping Operations at S-13 to Maintain Upstream Stages}

The coastal S-13 spillway operations in response to rising downstream stages during the high sea-level rise scenarios resulted in increased upstream stage (figs. 21 and 27). According to the linear stage-discharge operational function of the pump, pumping starts as the upstream stage rises $0.70 \mathrm{ft}$ above NAVD 88 and increases linearly to a peak rate of $540 \mathrm{ft}^{3} / \mathrm{s}$ when the upstream stage reaches $1.7 \mathrm{ft}$ above NAVD 88. Operating along this stage-discharge curve resulted in average increases of $0.744 \mathrm{ft}$ and $0.721 \mathrm{ft}$ in upstream stage for the wetter and drier high sea-level scenarios, respectively.
Pump operations were modified to maintain S-13 upstream stages at $0.11 \mathrm{ft}$ above NAVD 88 , which is the average stage for both base-case scenarios. The resulting stage-discharge operational function starts as the upstream stage rises above $0.0 \mathrm{ft}$ NAVD 88 , increases linearly to a rate of $85 \mathrm{ft}^{3} / \mathrm{s}$ at a stage elevation of $0.11 \mathrm{ft}$ above NAVD 88 , and then increases linearly to a peak rate of $540 \mathrm{ft}^{3} / \mathrm{s}$ when the upstream stage reaches $0.7 \mathrm{ft}$ above NAVD 88. This modified stage-discharge operation was simulated by using the county-scale model with the highest projected sea level and resulted in average $\mathrm{S}-13$ upstream stages of $0.15 \mathrm{ft}$ and $0.13 \mathrm{ft}$ for the wetter and drier future scenarios, respectively (fig. 33). The model-simulated average flow through the structure increased from $90.0 \mathrm{ft}^{3} / \mathrm{s}$ to $116.9 \mathrm{ft}^{3} / \mathrm{s}$ for the wetter future scenario and increased from $74.8 \mathrm{ft}^{3} / \mathrm{s}$ to $103.6 \mathrm{ft}^{3} / \mathrm{s}$ for the drier future scenario using the altered pump operation. The $\mathrm{S}-13$ model-simulated spillway flow was $0.0 \mathrm{ft}^{3} / \mathrm{s}$ for each of the altered pump operation future scenarios because of the reduced upstream stage and increased downstream stage due to sea-level rise. The effect on groundwater levels was limited to the area between the S-13 and S-13a structures, extending north to the North New River Canal and south toward the $\mathrm{C}-9$ Canal, with a maximum decrease in average groundwater of $0.70 \mathrm{ft}$ (fig. 34). 
A. Wetter future, low sea-level rise

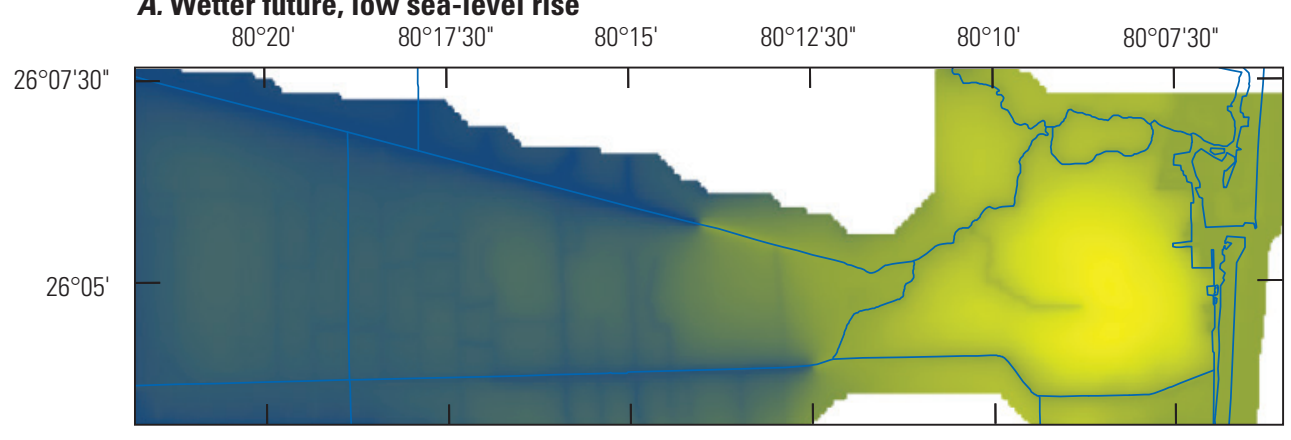

\section{$B$. Wetter future, intermediate sea-level rise}
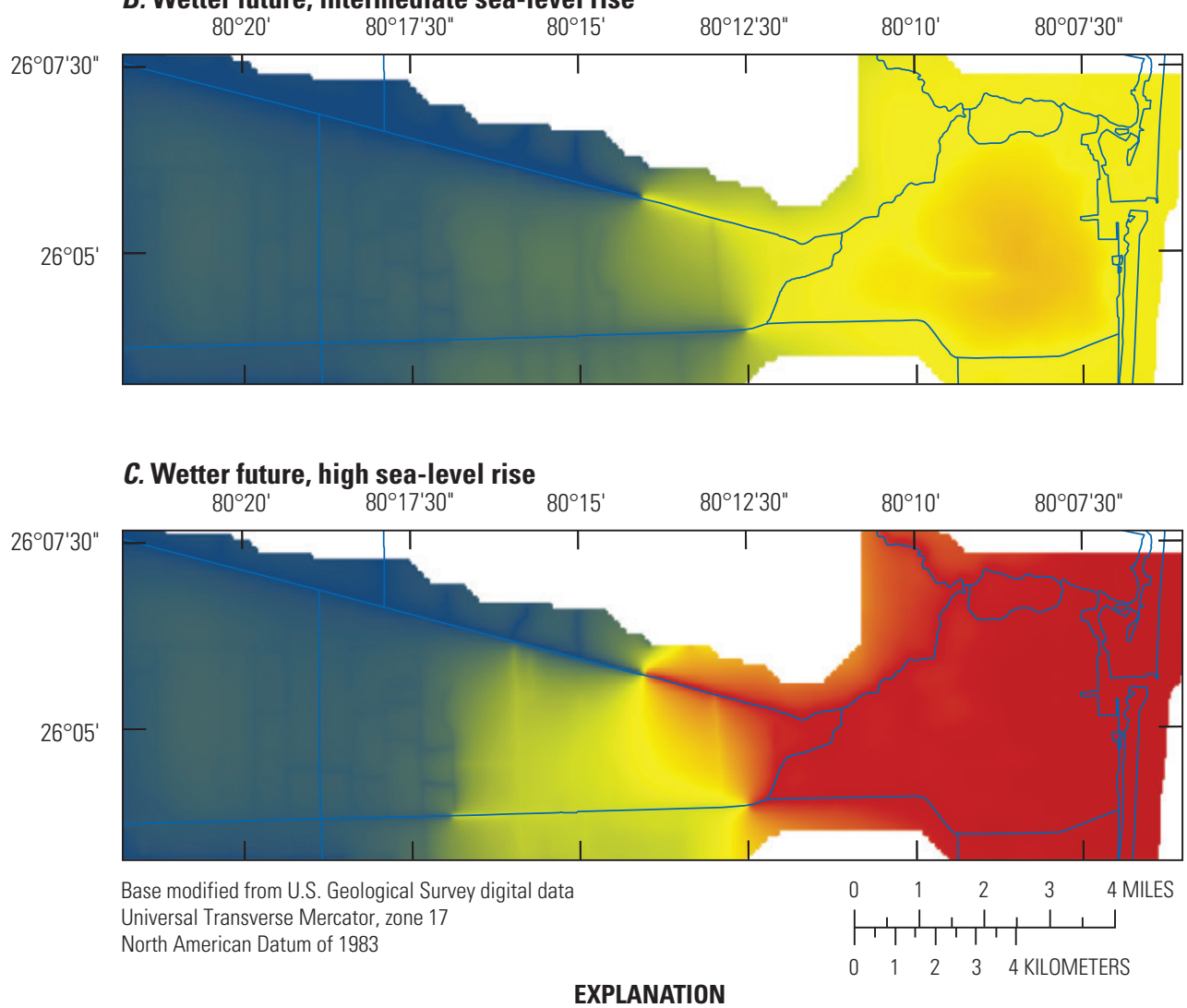

Average wet-season groundwater-level increases, in feet

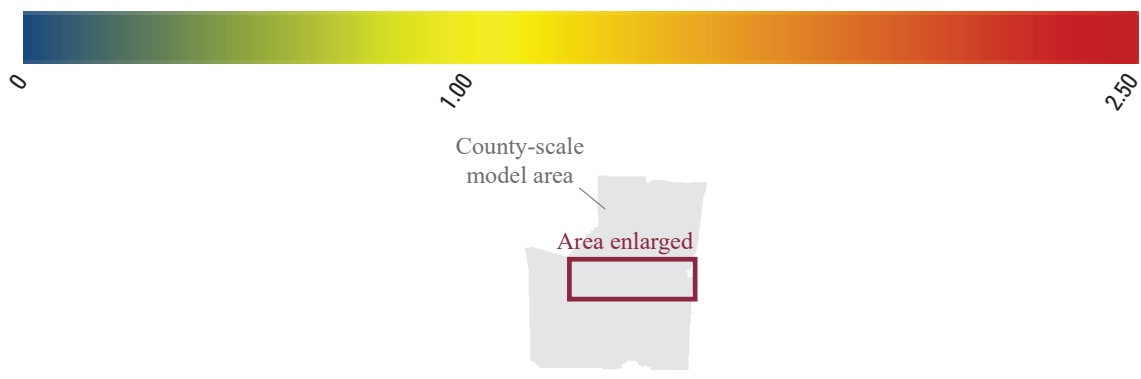

Figure 29. Average wet-season groundwater-level increases in the local-scale model for wetter future $A$, low; $B$, intermediate; and $C$, high sea-level rise scenarios. 
A. Drier future, low sea-level rise

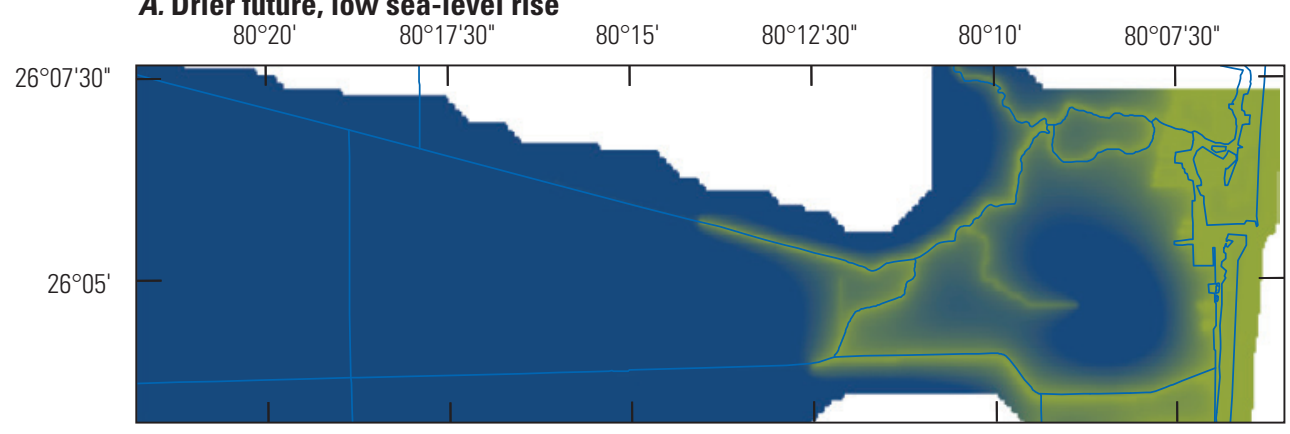

B. Drier future, intermediate sea-level rise
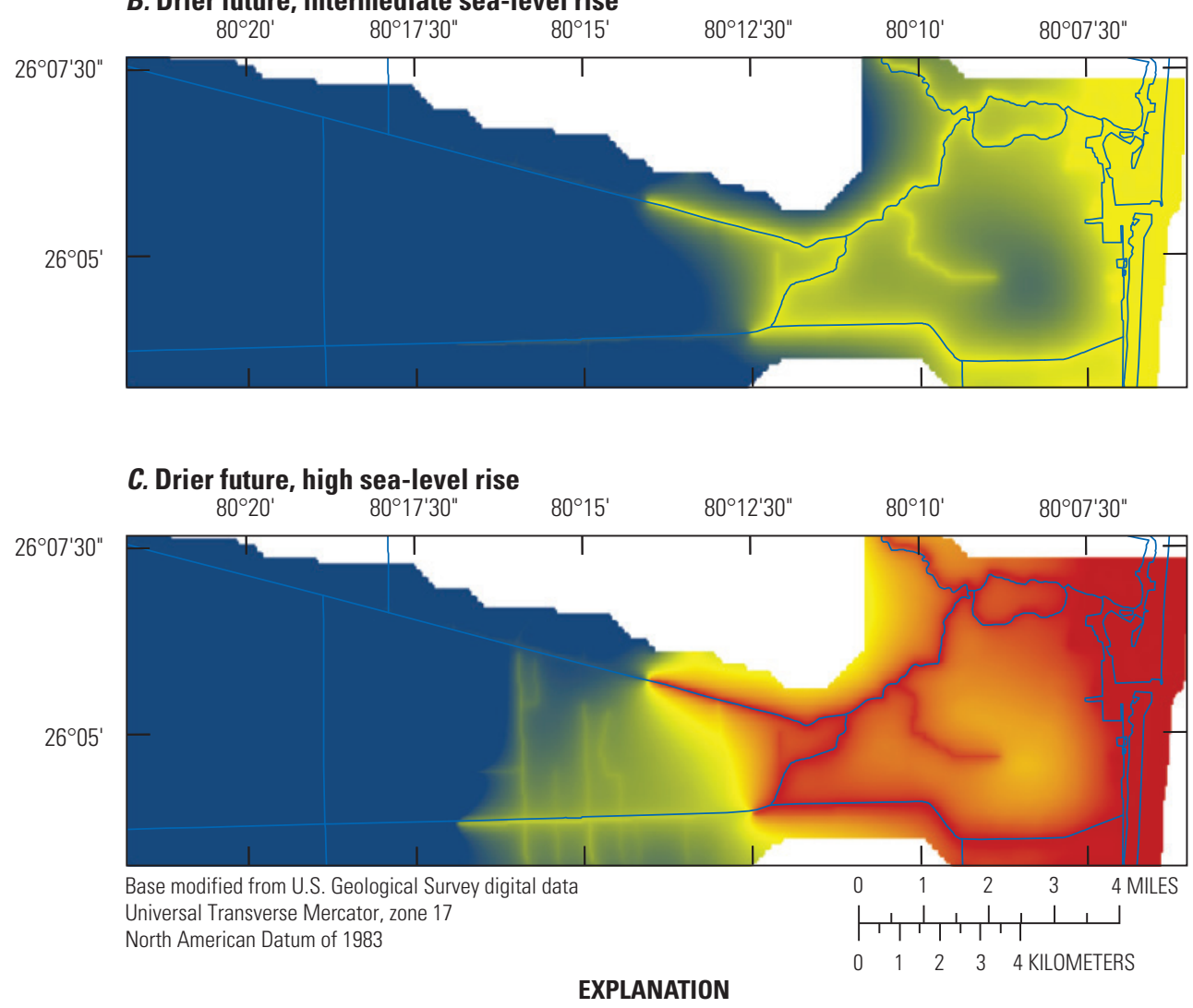

Average wet-season groundwater-level increases, in feet

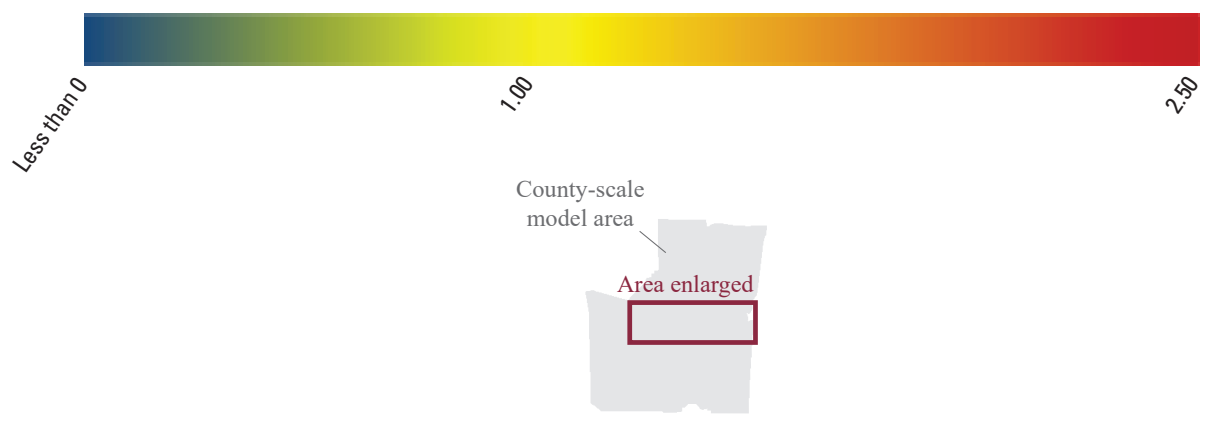

Figure 30. Average wet-season groundwater-level increases in the local-scale model for drier future $A$, low; $B$, intermediate; and $C$, high sea-level rise scenarios. 
A. Community Climate System Model base case

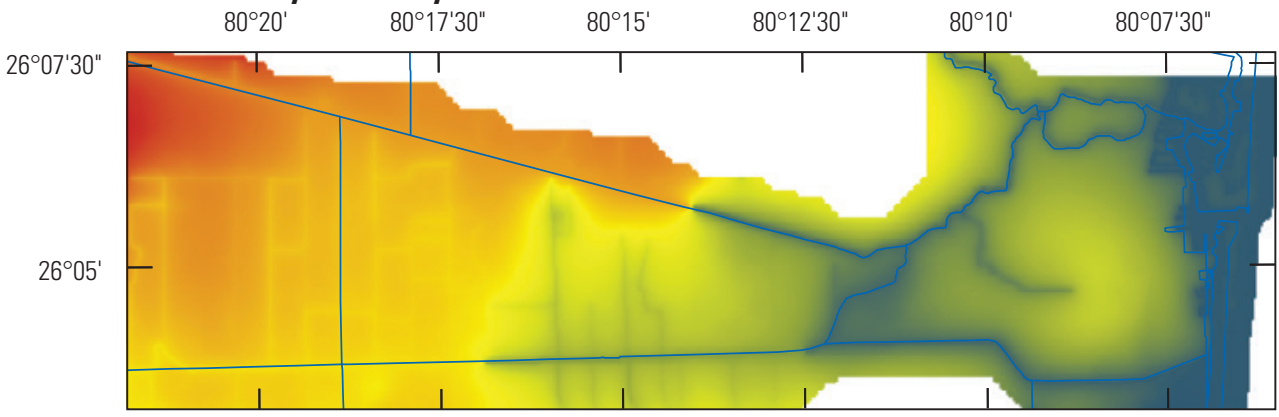

\section{$B$. Wetter future, high sea-level rise}
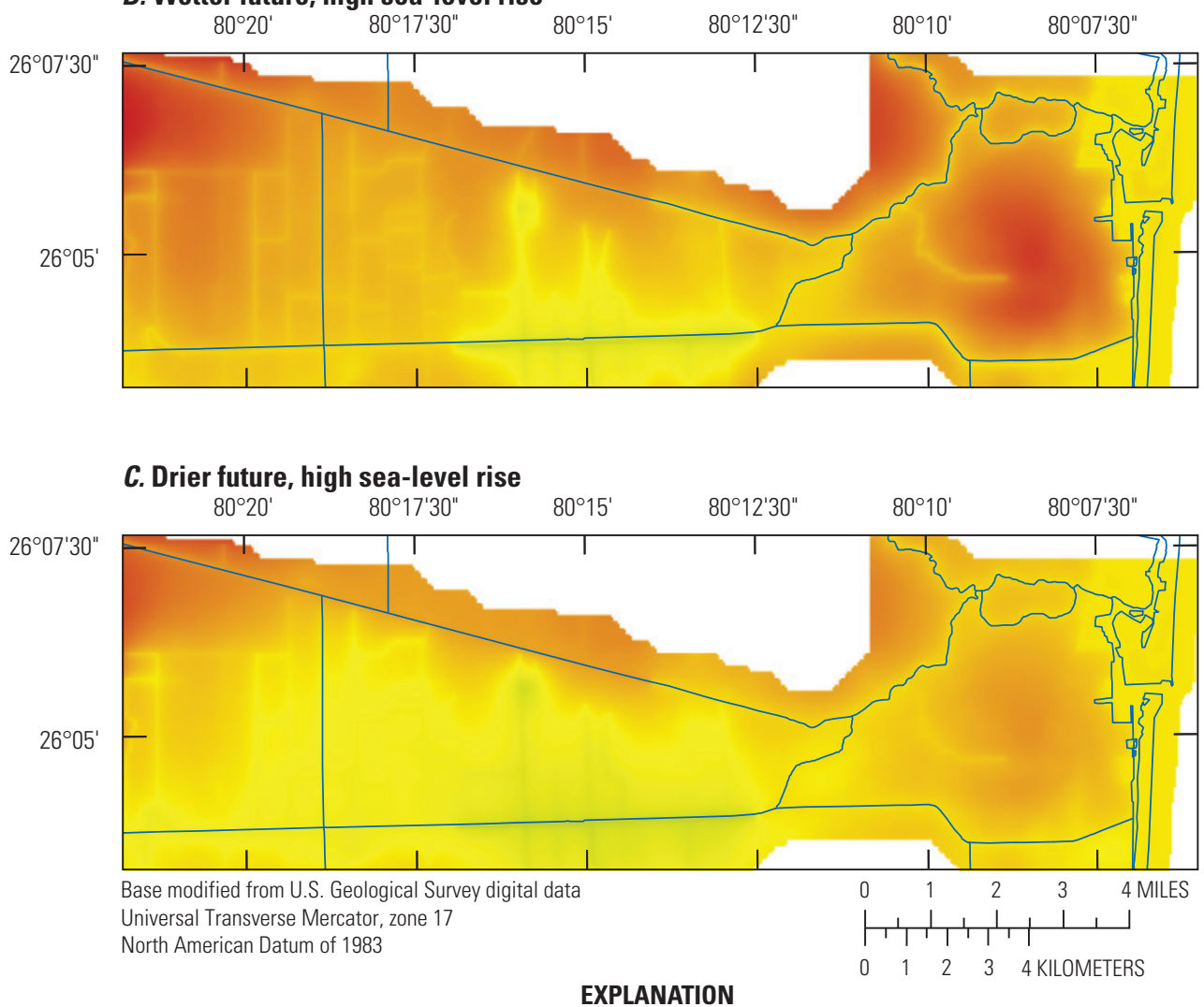

Groundwater level, in feet above North American Vertical Datum of 1988

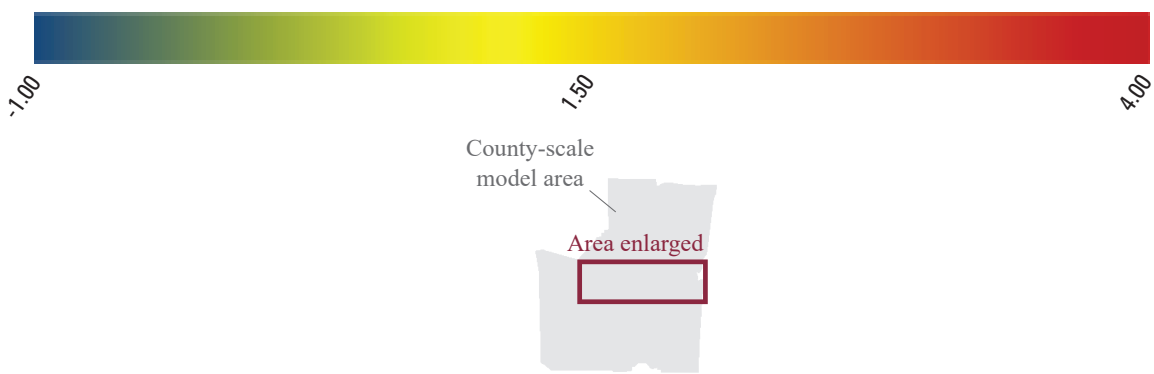

Figure 31. Average wet-season groundwater level for $A$, base-case and high sealevel rise; $B$, wetter; and $C$, drier future climate scenarios for the local-scale area. 

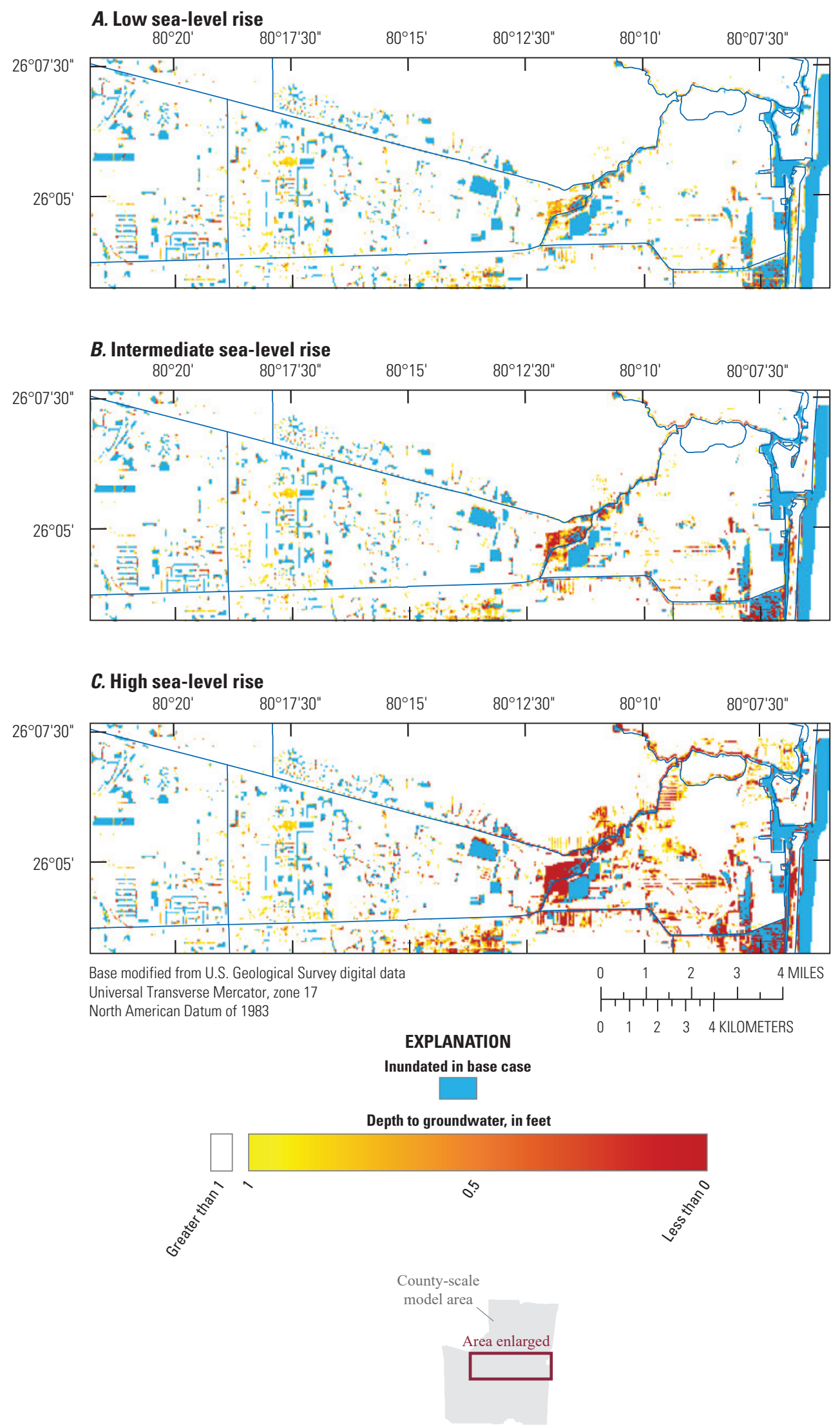

Figure 32. Average wet-season depth to groundwater in the local-scale model for wetter future $A$, low; $B$, intermediate; and $C$, high sea-level rise scenarios. 


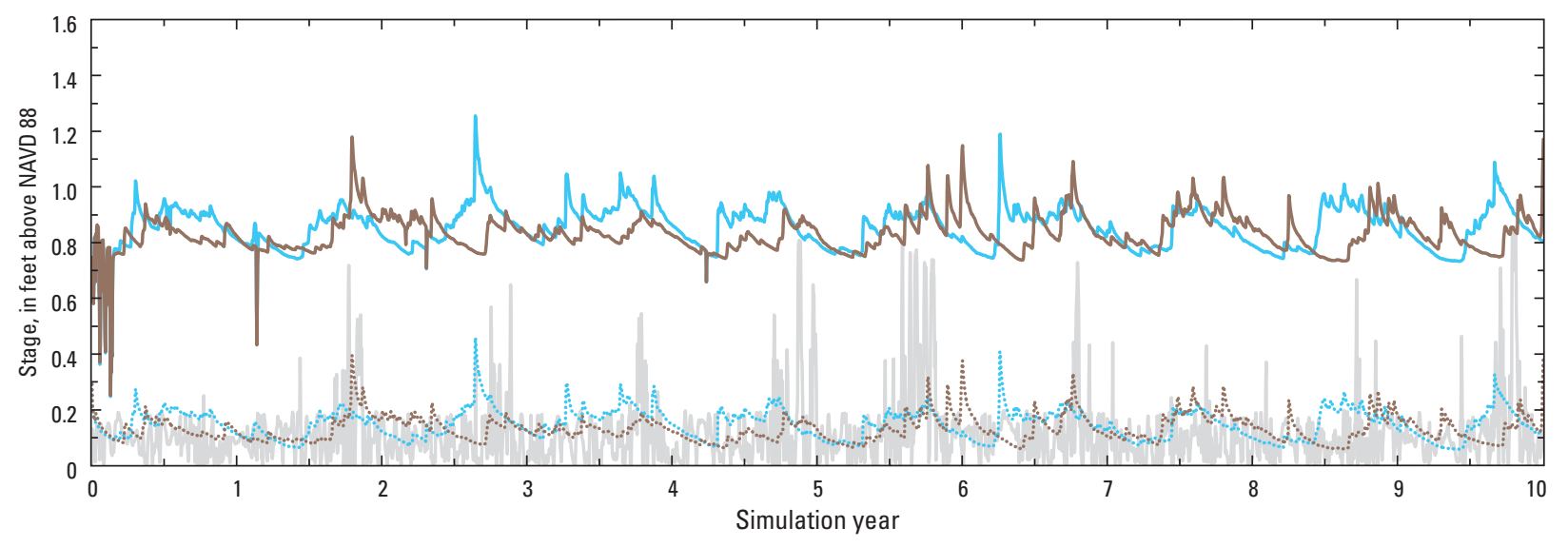

EXPLANATION

Upstream stage, in feet above North American

Vertical Datum of 1988 (NAVD 88), at structure

S-13, by scenario

Community Climate System Model base case

Original operations (wetter)

Original operations (drier)

Altered operations (wetter)

Altered operations (drier)

Figure 33. Upstream stage at structure $S-13$ for wetter and drier high sea-level rise scenarios with original and altered S-13 pump operations for 1990-99 or 2060-69.

\section{Pumping Groundwater to Reduce Potential for Inundation}

Additional adaptation strategies were simulated by using the local-scale model to examine the concept of using pumps to reduce the local groundwater levels in neighborhood-sized areas and to thereby reduce the potential for inundation from sea-level rise and precipitation events. For these scenarios, pumping of groundwater to maintain three specified control elevations was simulated in two areas of interest (fig. 35). For these scenarios, the excess groundwater was assumed to be removed from the area. The magnitude of the average and peak pumping rates required to maintain groundwater levels at the control elevations provide city planners and water resource managers an indication of the potential effort required to prevent inundation in these areas. A major limitation to these results is the uncertainty in localized soil and aquifer properties in the areas, which would have a substantial effect on required pumping rates to prevent inundation. Additionally, local surface-water control features such as drains, piped connections, and direct runoff connections are not explicitly simulated, and in reality, these features could have an effect on drainage rates.

The two selected areas were each composed of 21 columns and 21 rows within the local-scale model, representing $0.439 \mathrm{mi}^{2}$ each (fig. 35). The pumping of excess groundwater was simulated by using the MODFLOW 2005 Drain package (DRN). The conductance used for DRN features representing the pumping of excess groundwater was uniformly set to 25,000 square feet per day. Area 1 is a coastal site that showed an increase of $2.50 \mathrm{ft}$ in average wet-season groundwater levels during the wetter high sea-level rise scenario. Area 1 has strong connections to tidal boundaries. The specified groundwater-control elevations were set to values that would allow increases in groundwater levels of zero, $1 \mathrm{ft}$, and $2 \mathrm{ft}$ above the average wet-season levels from the base-case simulation for each cell. The resulting average groundwater-control elevations for Area 1 were $-0.61 \mathrm{ft}, 0.39 \mathrm{ft}$, and $1.39 \mathrm{ft}$ above NAVD 88 . Area 2 is west of Area 1 and east of the S-13 and G-54 control structures; Area 2 showed an increase of $2.36 \mathrm{ft}$ in average wet-season groundwater levels during the wetter high sea-level rise scenario (fig. 35). Area 2 was farther removed from tidal boundaries than Area 1 but was strongly hydraulically connected to canal reaches within the area. Conditions representing the wetter high sea-level rise inputs were simulated by using three groundwater-control elevations: zero, $1 \mathrm{ft}$, and $2 \mathrm{ft}$ above the base-case average wet-season groundwater levels within each cell. This simulation resulted in average groundwater-control elevations for Area 2 of $0.08 \mathrm{ft}, 1.08 \mathrm{ft}$, and $2.08 \mathrm{ft}$ above NAVD 88 .

The average simulated wet-season groundwater levels within Area 1 were $0.54 \mathrm{ft}, 1.07 \mathrm{ft}$, and $1.78 \mathrm{ft}$ above NAVD 88 for the three scenarios, with groundwater-control elevations representing zero, $1 \mathrm{ft}$, and $2 \mathrm{ft}$ of groundwater-level increase from base conditions, respectively. When compared to the base-case average level of $-0.61 \mathrm{ft}$ above NAVD 88 , these values result in average wet-season groundwater-level increases of $1.15 \mathrm{ft}, 1.68 \mathrm{ft}$, and $2.39 \mathrm{ft}$ for the zero, $1 \mathrm{ft}$, and $2 \mathrm{ft}$ groundwater-control elevation scenarios, respectively. The average rates of groundwater pumping required to maintain the control groundwater elevations in Area 1 were $2,220.0 \mathrm{ft}^{3} / \mathrm{s}, 1,262.5 \mathrm{ft}^{3} / \mathrm{s}$, and $346.6 \mathrm{ft}^{3} / \mathrm{s}$ for the zero, $1-\mathrm{ft}$, and 2 -ft control elevations, respectively (fig. 36). Because of 


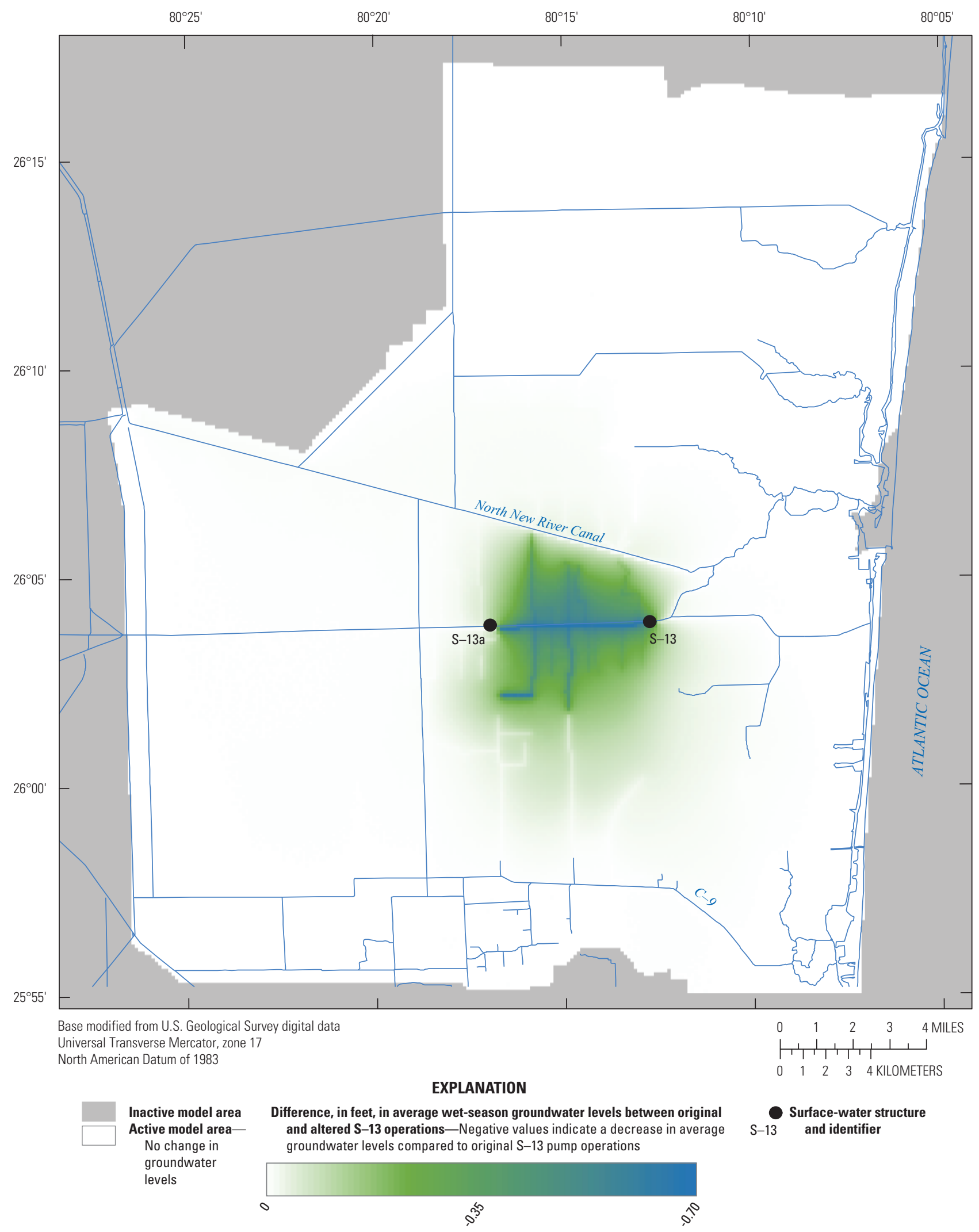

Figure 34. Difference in average wet-season groundwater levels between original and altered S-13 pump operations for the wetter future high sea-level rise scenario. Negative values indicate a decrease in average groundwater levels compared to original S-13 pump operations. 


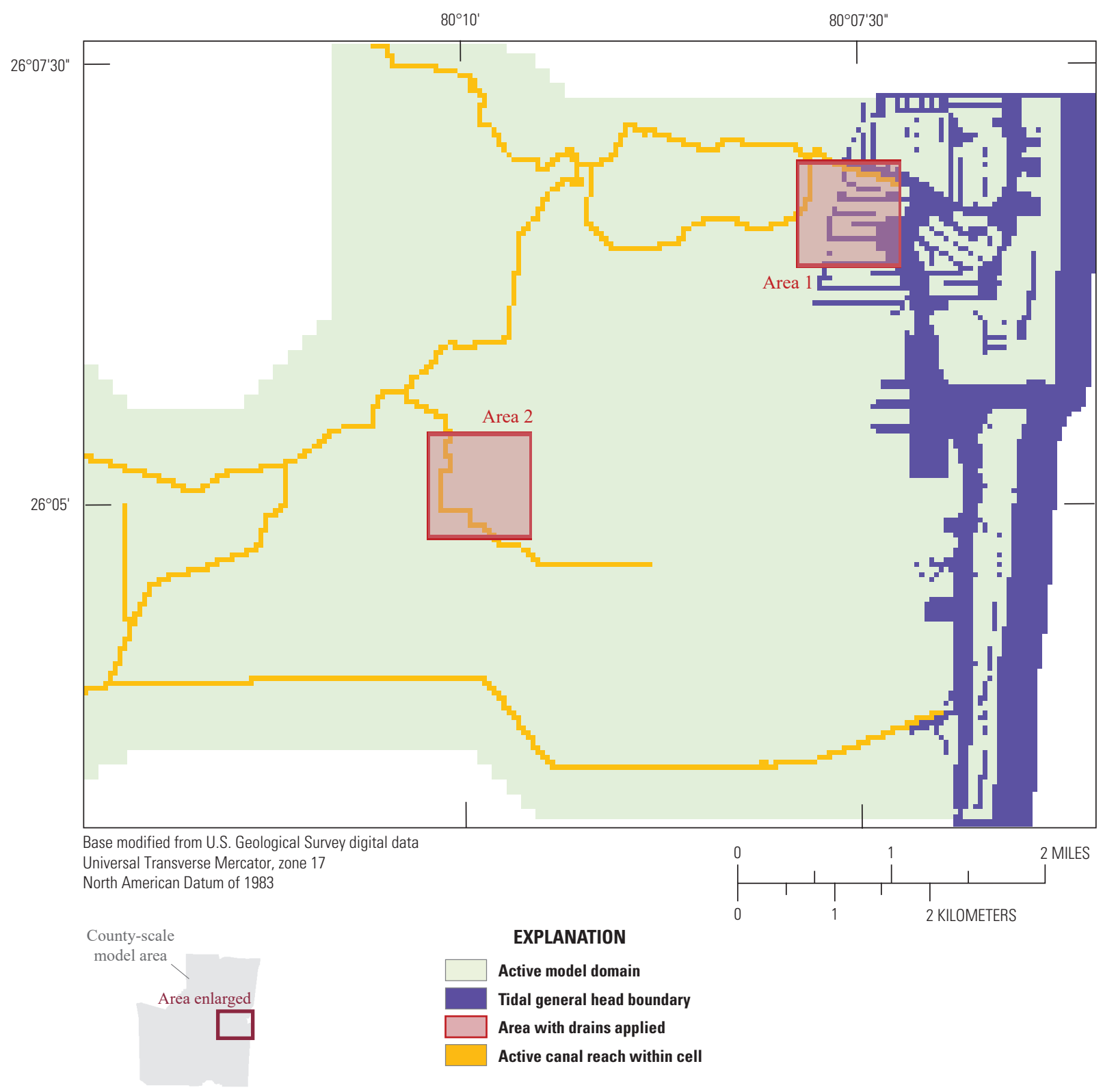

Figure 35. Areas 1 and 2 for wetter future pumped adaptation strategy simulation.

the strong connection of Area 1 to general head boundaries (GHBs) representing the Intracoastal Waterway and the high conductivity used to characterize the aquifer, a large volume of water was removed, which caused considerable increases in groundwater levels despite the established drainage control elevations. The discharge of the large volumes of water removed in these scenarios represents an additional problem. As modeled, the water is assumed to be pumped to tide and is simply removed from the model. Some strategies could be devised to store and release water during low tidal periods, but such strategies were not addressed during these simulations and were beyond the scope of this study.

The average model-simulated wet-season groundwater levels within Area 2 were $0.31 \mathrm{ft}, 1.17 \mathrm{ft}$, and $1.71 \mathrm{ft}$ above
NAVD 88 for the three scenarios with drainage elevations representing zero, $1 \mathrm{ft}$, and $2 \mathrm{ft}$ of groundwater level increase from base conditions, respectively. When compared to the base-case average level of $0.08 \mathrm{ft}$ above NAVD 88 , these values are average wet-season groundwater-level increases of $0.23 \mathrm{ft}, 1.09 \mathrm{ft}$, and $1.63 \mathrm{ft}$. The average rates of groundwater pumping required to maintain the control groundwater elevations in Area 2 were $636.0 \mathrm{ft}^{3} / \mathrm{s}, 271.5 \mathrm{ft}^{3} / \mathrm{s}$, and $28.6 \mathrm{ft}^{3} / \mathrm{s}$ for the zero, 1 -ft, and 2-ft control elevations, respectively (fig. 36). These volumes are substantially less than those removed from Area 1 but still represent a considerable volume because of the high conductivity used to characterize the aquifer and the connection to canal reaches that pass through the same area. 


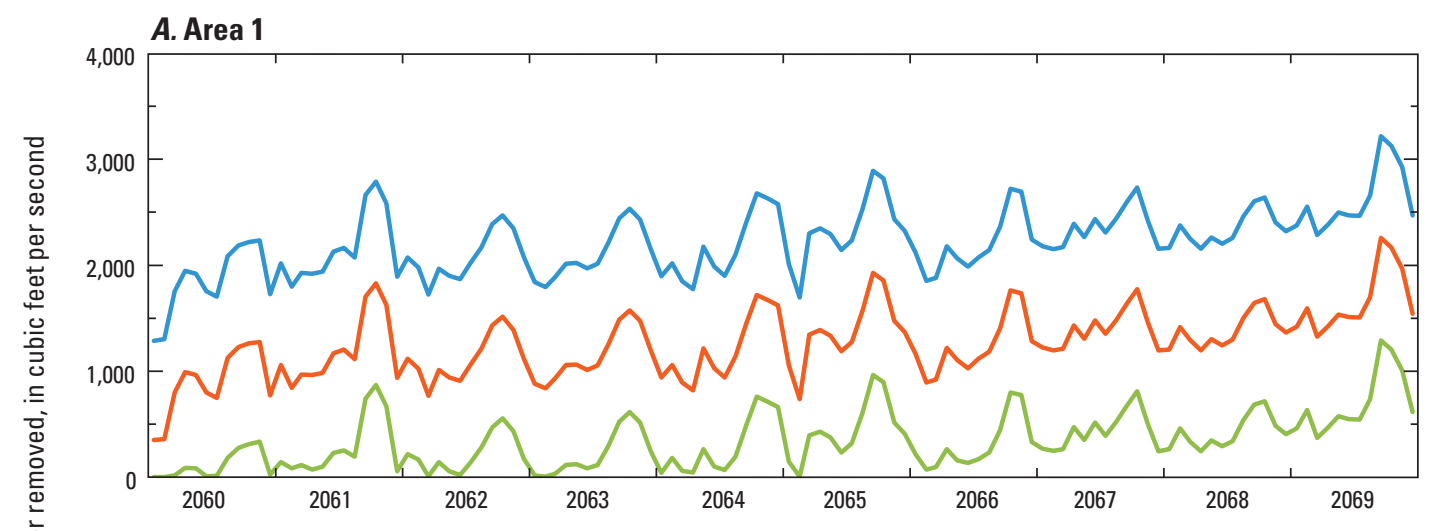

B. Area 2

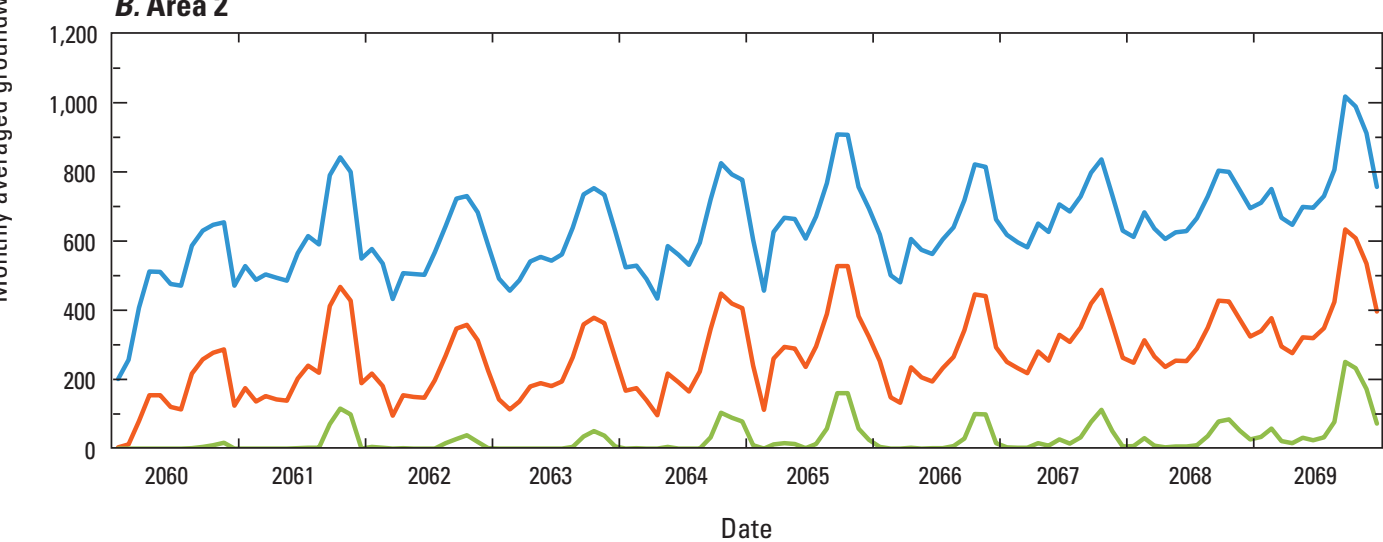

EXPLANATION

Groundwater-level increase from base-case scenario, in feet

- 0 - 12

Figure 36. Monthly averaged groundwater being removed from $A$, Area 1, and $B$, Area 2 during drainage scenarios with drainage elevations set to levels zero, 1 foot, and 2 feet above basecase scenario wet-season averages within each cell.

\section{Model Limitations}

The general limitations of the numerical models include the following:

- A hydrologic model's ability to mimic past hydrologic conditions does not necessarily guarantee ability to predict future conditions. When hydrologic forcings move further away in time or magnitude from forcings for which the model was calibrated, the model is less likely to accurately represent the conditions of the hydrologic system.

- Models are limited by their spatial and temporal resolutions. Processes and responses that occur on shorter temporal and spatial scales than those represented in the model may not be captured accurately.

- The model is limited by the necessarily simplified representation of natural processes. The conceptual model used to represent the hydrologic flow system and the numerical methods used to solve the mathematical model representation of this conceptual model are both only approximations of the actual hydrologic flow system.

There are more specific limitations of the model listed in the following sections that should be considered when analyzing the results.

\section{Groundwater-Model Properties}

- Groundwater properties for the inundation models were derived from the southern and central Broward County saltwater-intrusion model, which was calibrated with the primary focus of history matching salinity concentrations. Any uncertainties and errors introduced by the saltwater-intrusion model are propagated into the inundation models. These values were averaged to obtain composite parameters for the three vertical layers used for the county-scale model and interpolated to obtain the parameters for the local-scale model, potentially accumulating more error. 


\section{Western Groundwater Head Boundaries}

- The western boundaries near the WCAs are represented by data obtained from EDEN. These designated GHB values appear to be higher than expected and are often higher than ground elevations at the boundary. This may allow more water to enter the system through this boundary, which may result in greater groundwater discharge into the North New River Canal than actually occurs (appendix 3 ).

- Future groundwater levels at the model boundaries are uncertain but likely differ from current elevations, particularly as any changes are made to management of the Everglades or to the WCAs. For this study, historical GHB input values are used in future scenarios.

\section{Tidal Boundaries}

- Groundwater head boundaries representing tidal levels were created by using a combination of two tide measurement locations (Haulover Pier and Virginia Key tidal stations; described in detail in appendix 2) and NOAA's tidal generator/predictor. Neither of these tidal gages is within the model's geographic domain, and there is a data gap of approximately 515 days, which is populated by using the tidal generator. No attempt was made to correct for tidal stage or timing differences due to geographical location. If actual tidal levels are higher or lower than implemented in the model, the resulting groundwater levels would alter the depth to water and soil storage capacities within base-case and future scenarios. Additionally, coastal structure operations would be affected by changes in tidal inputs.

- GHBs representing the Intracoastal Waterway are approximated by using the same tidal data series, and changes in available data would affect local groundwater levels. The representation of sea-level rise involves adding the projected rise for each scenario to the historical time series and does not account for shifts in the daily series or any imbedded natural cycles.

- The county-scale model uses daily tidal levels for both the surface-water and groundwater boundaries, whereas the local-scale model uses hourly tidal levels. The difference in results is evident in pumped versus spillway flow at structure $\mathrm{S}-13$ in future simulations. Without the representation of daily low tidal levels within the county-scale models, the pump must be operated more often because of averaged downstream stage conditions.

\section{Canal Representation}

- Active canal representation in the county-scale model is limited to only a central part of the county that encompasses the local-scale model area. The active part was chosen on the basis of location and connection types to neighboring canal sections to best represent the behavior of the system within the local-scale area. The remaining parts of the canal system have specified stages throughout the simulation that remain unchanged for all scenarios and may act to dampen or conceal changes in adjacent areas during future simulations.

- Active canal segments are represented as level pools. Given the low surface-water gradients seen west of the coastal control structures, this assumption may not significantly affect model accuracy.

- Surface-water control structures within the model are represented with the intent to capture the system's behavior and may deviate from the actual systems. For example, pumps are operated as stage-discharge relationships, gates may use opening and closing speeds that differ from documented values, and some gates are implemented as fixed-crest weirs. Additionally, the operation of these structures is governed by specific rules within the models, which are frequently and randomly not followed in actual operation, and these ad hoc operations were not simulated. The resulting simulated hydrologic conditions should and do differ from measured hydrologic conditions.

- The limited or generic cross-sectional data available for some parts of the canal system can have an effect on the accuracy of the calculated canal storage and flow for historical and future simulations. For example, a canal reach with an overestimated top width would have a lower increase in stage change for a given volume, and conversely, a canal with an underestimated top width would have a higher increase in stage for the same given volume.

- Frictional coefficients specified for the canal system and structures were generated from standard values and may deviate from actual characteristics. Overestimated frictional coefficients between reach groups would cause increased stage differences between the groups to achieve the same flow rates. Conversely, underestimated frictional coefficients would cause decreased stage differences between the reach groups to achieve the same flow rates.

- Canal leakance coefficients were calculated by using calibrated leakage values from the MODFLOW 2005 River package (RIV) used in the central and southern Broward County saltwater-intrusion model (Hughes and others, 2016). As mentioned, this model was calibrated with the primary focus of history matching of saltwater transport and canal leakance values derived from the cited model may not be the optimum values for the current simulations; however, the leakance values are within the range of standard values. 


\section{Precipitation and Potential Evapotranspiration}

- Potential ET for the historical simulation was assumed to be uniform over the model extent. Actual potential ET may have varied spatially and would differ from the actual water volume removed from the model. Potential ET for the baseline and future scenarios was applied on the basis of the $10-\mathrm{km}$ climate model grid while potential ET may vary at a smaller scale and could cause similar differences.

- The baseline and future scenario precipitation was applied based on the 10-km climate model grid. For consistency, historical precipitation calculated from various measured rainfall stations was applied based on the same $10-\mathrm{km}$ grid. Actual precipitation may have finer-scale spatial variability and could cause differences in simulated model output.

\section{Future Climate and Sea-Level Projections}

- Projections of sea-level change and climate change are generally highly uncertain. They represent the outcome of complex systems with complicated interactions. The further into the future, the more uncertain the projections become. The scenarios presented within this report do not represent the exact expectation of future conditions but rather represent possible combinations of conditions. More extreme projections exist but typically have a lower chance of occurrence and were not considered.

\section{Summary}

A county-scale MODFLOW 2005 groundwater/ surface-water model of the urban areas of southern and central Broward County was developed to simulate the possible effects of potential changes in precipitation, evapotranspiration, and sea level on groundwater levels. The primary data source for model construction and hydraulic parameters was an existing saltwater-intrusion model of the same area. The aquifer layering was vertically simplified to represent upper, production, and lower zones. The representation of the extensive canal network was accomplished using dynamic canal stages computed using level-pool routing with dynamic structure flows for the central portion of the study area. The remaining northern and southern parts used observed, specified stages within the reaches. Precipitation, evaporation, infiltration, recharge, and surface-water and unsaturated zone storages were represented by using a newly developed Urban Runoff process. The temporal scale was modified from monthly to daily stress periods. Additionally, a local-scale model was developed with more refined spatial and temporal scales, and additional detail was added to the active canal network.

Simulations were run by using observed rainfall, potential evapotranspiration, and tidal levels from 1990 to 1999 to gauge the model's ability to capture the historical behavior of the hydrologic system. Fit statistics and time-series data were calculated and analyzed for several groundwater station locations and the primary active canal structures. Projected future scenarios were constructed for the years 2060-69 by using regional climate model output derived from two general circulation models and three different sea-level rise curves. The precipitation and potential evapotranspiration from the Community Climate System Model (CCSM) and Hadley Centre Coupled Model version 3 (HadCM3) regional climate model scenarios represented possible wetter and drier futures, respectively, with a 9.1-percent increase and a 7.6-percent decrease in average yearly precipitation totals, respectively, for the county-scale model area. Low, intermediate, and high sea-level rise curves were created that represented the currently measured linear rate of increase and the National Research Council Curves I and III; these resulted in average tidal level increases of 6.2 inches (in.), 11.9 in., and $29.9 \mathrm{in}$. for the 2060-69 time period relative to 2010. Base-case simulations using regional climate model precipitation and potential evapotranspiration for the CCSM and HadCM3 scenarios and measured tidal observations from 1990 to 1999 were run and used for comparison to the future scenarios.

For the county-scale model area, the base-case CCSM and HadCM3 regional climate model output underestimated averaged precipitation values for 1990-99 with totals of 53.4 inches per year (in/yr) and $54.9 \mathrm{in} / \mathrm{yr}$, respectively, compared to an observed $62.5 \mathrm{in} / \mathrm{yr}$. Wet-season precipitation totals were also underestimated but less so, with averages of 38.7 in. and 40.0 in. for the base-case CCSM and HadCM3, respectively, compared to a measured average of $43.0 \mathrm{in}$. The base-case scenario groundwater-level results were compared to the historical scenario model results with mean differences in groundwater levels of $-0.045 \mathrm{feet}(\mathrm{ft}$ ) and $-0.015 \mathrm{ft}$ in the 15 groundwater station locations for the CCSM and HadCM3 Base-Case scenarios, respectively. When compared to the historical simulation, the mean differences in discharge at the four primary flow structures ( $\mathrm{G}-54, \mathrm{~S}-13, \mathrm{~S}-33$, and S-9) during the CCSM and HadCM3 Base-Case simulations were -11.0 cubic feet per second $\left(\mathrm{ft}^{3} / \mathrm{s}\right)$ and $-6.42 \mathrm{ft}^{3} / \mathrm{s}$, respectively.

When analyzing and comparing the simulation results by using future projections, it is important to focus more on the qualitative effects evidenced in the output rather than exact quantitative results. Important findings include direction and range in magnitude of changes in simulated results under projected future scenarios and determining the primary cause of these changes. On the basis of the simulations using future sea-level rise and climate projections, several observations were made analyzing the results of the county-scale model:

- The effects of the future scenarios are much more evident in eastern and coastal areas, which show groundwater level increases nearly equivalent to 
the tidal level increases. These groundwater level increases are distributed further inland in the wetter future scenarios than in the drier future scenarios. This finding indicates the primary driver for increased groundwater levels and subsequent reductions in soil storage is sea-level rise for these coastal areas, and projected climate can enhance or reduce these effects.

- Average groundwater levels at the easternmost groundwater wells increased $0.525 \mathrm{ft}$ and $0.329 \mathrm{ft}$ for the low sea-level rise scenarios for the wetter and drier future scenarios, respectively. The average sea-level rise for these scenarios was $0.514 \mathrm{ft}$.

- Average groundwater levels at the easternmost groundwater wells increased $0.909 \mathrm{ft}$ and $0.716 \mathrm{ft}$ for the intermediate sea-level rise scenarios for the wetter and drier future scenarios, respectively. The average sea-level rise for these scenarios was $0.991 \mathrm{ft}$.

- Average groundwater levels at the easternmost groundwater wells increased $2.085 \mathrm{ft}$ and $1.911 \mathrm{ft}$ for the high sea-level rise scenarios for the wetter and drier future scenarios, respectively. The average sea-level rise for these scenarios was $2.491 \mathrm{ft}$.

- The westernmost groundwater station locations exhibited little change caused by sea-level rise and showed more dependence on changes in precipitation but with a much-reduced overall effect compared to the coastal wells. The averaged groundwater levels within these wells for the wetter future scenarios increased $0.021 \mathrm{ft}, 0.024 \mathrm{ft}$, and $0.033 \mathrm{ft}$ for the low, intermediate, and high sea-level rise scenarios, respectively.

The same westernmost wells exhibited average groundwater-level decreases of $0.064 \mathrm{ft}, 0.060 \mathrm{ft}$, and $0.051 \mathrm{ft}$ for the drier future low, intermediate, and high sea-level rise scenarios, respectively.

- There was a lessened west-to-east groundwater gradient through the central part of the county-scale model, which also crosses through the local-scale model area, for the future scenarios relative to historical conditions. These groundwater levels and gradients change very little west of structure S-13a on the C-11 Canal, which acts as a divide. Canal levels in the western part of the C-11 Canal are controlled by the western discharge of water through the S-9 pump structure. Groundwater levels east of S-13a are controlled by the eastern part of the $\mathrm{C}-11 \mathrm{Canal}$ and structure $\mathrm{S}-13$ and increase with increased sea-level rise, particularly in the high sea-level rise scenario. In this scenario, the increased downstream stage at structure $\mathrm{S}-13$ from sea-level rise reduces the spillway capacity, and coastal flows must be maintained through pump operations. The stage-discharge relationship that represents the S-13 pump operates at a higher upstream stage and increases the local groundwater levels.
- Results obtained by using the wetter future inputs show an increase of 2.484 square miles $\left(\mathrm{mi}^{2}\right)(+3.0$ percent$)$, $3.757 \mathrm{mi}^{2}\left(+4.6\right.$ percent), and $12.106 \mathrm{mi}^{2}$ $(+14.8$ percent $)$ in areas with less than a $1-\mathrm{ft}$ depth to average wet-season groundwater level. These areas are considered to have a high likelihood of inundation and extended flooding during precipitation events.

- Alterations to S-13 pump operations within the mode can be used to reduce the effects of sea-level rise, but the affected area is spatially limited.

Groundwater levels and canal flows from the county-scale model were used as boundary conditions and inputs for the local-scale model. The results and observations from the local-scale model were similar to those from the larger, coarser county-scale model with similar fit statistics and qualitative fits for the historical and base-case scenarios. Based on the simulations using future sea-level rise and climate projections, several observations were made by analyzing the results of the local-scale model:

- The effects of the underestimated yearly precipitation totals for the historical period by the regional climate models were more pronounced in the local-scale model area than in the county-scale model. The CCSM and HadCM3 Base-Case regional climate model output scenarios respectively had average yearly precipitation that was 18.3 percent and 15.9 percent lower than measured totals. The three groundwater station locations in the local-scale area were an average of $0.379 \mathrm{ft}$ and $0.339 \mathrm{ft}$ lower for the CCSM and HadCM3 Base-Case scenarios, respectively, than for the historical scenario. The two primary structure flows, G- 54 and S-13, were a mean of $23.0 \mathrm{ft}^{3} / \mathrm{s}$ and $19.1 \mathrm{ft}^{3} / \mathrm{s}$ lower for the CCSM and HadCM3 scenarios, respectively, when compared to the historical scenario. The time series for the groundwater levels and structure flows had similar peaks and trends to the historical scenario results and the county-scale model's base-case scenarios.

- Similar to the county-scale model results, the coastal areas exhibited the largest effects in groundwater levels in the future scenarios. Yearly precipitation totals increased 18.8 percent within the local-scale area in the wetter future scenario and resulted in average groundwater-level increases of $0.710 \mathrm{ft}$, $1.133 \mathrm{ft}$, and $2.423 \mathrm{ft}$ in the easternmost groundwater well for the low, intermediate, and high sea-level rise scenarios, respectively. The drier future scenario had a 7.0-percent decrease in rainfall, and the results show average groundwater-level increases of $0.345 \mathrm{ft}$, $0.777 \mathrm{ft}$, and $2.103 \mathrm{ft}$ in the same groundwater wells for the low, intermediate, and high sea-level rise scenarios, respectively.

- As seen in the county-scale model, the westernmost interior areas exhibited little change during the future scenarios. The westernmost monitoring location had average groundwater-level increases of 
$0.037 \mathrm{ft}, 0.034 \mathrm{ft}$, and $0.036 \mathrm{ft}$ for the wetter future low, intermediate, and high sea-level rise scenarios, respectively. The westernmost monitoring location had average groundwater-level decreases of $0.116 \mathrm{ft}$ and $0.121 \mathrm{ft}$ for the drier future low and intermediate sea-level rise scenarios, respectively, and a decrease of $0.121 \mathrm{ft}$ for the drier future high sea-level rise scenario.

- Similar operational changes were seen at structure $\mathrm{S}-13$ in the local-scale simulations as in the county-scale simulations; however, there was less reliance on the pump during the high sea-level rise scenarios because of the hourly tidal stage inputs used in the local-scale model. The county-scale model used daily tidal levels, which neglected the daily low tide levels that allowed intermittent operation of the gated spillway at S-13 in the local-scale area. As a result, reliance on pumped versus spillway flow shifted from 99 percent in the county-scale model to approximately 71.2 percent in the local-scale model. Upstream stage at $\mathrm{S}-13$ was increased during the high sea-level rise scenarios because of the operational rules of the stage-discharge relationship. Upstream levels increased $0.693 \mathrm{ft}$ and $0.670 \mathrm{ft}$ for the wetter and drier high sea-level rise scenarios, respectively, compared to increases of $0.744 \mathrm{ft}$ and $0.721 \mathrm{ft}$ for the wetter and drier sea-level rise scenarios, respectively, for the county-scale model. The concept of using pumps to reduce the local groundwater levels in two neighborhood-sized areas was tested by using the local-scale model. Area 1 was coastal, with strong connections to the general-head boundaries representing the tidal fluctuations. Area 2 was more inland but still east of the coastal water-control structures and had only limited connection to a simulated tidal reach. Drainage elevations were set to zero, $1 \mathrm{ft}$, and $2 \mathrm{ft}$ above average wet-season groundwater levels for each area. The amount of groundwater removed from Area 1 varied from $2,220.0 \mathrm{ft}^{3} / \mathrm{s}$ to $346.6 \mathrm{ft}^{3} / \mathrm{s}$ for the three drainage elevation scenarios. The amount of groundwater removed from Area 2 varied from $636.0 \mathrm{ft}^{3} / \mathrm{s}$ to $28.6 \mathrm{ft}^{3} / \mathrm{s}$ for the three drainage elevation scenarios.

\section{References Cited}

Andersen, P.F., Mercer, J.W., and White, H.O., Jr., 1988, Numerical modeling of salt-water intrusion at Hallandale, Florida: Groundwater, v. 26, no. 5, p. 619-630.

Broward County, 2009, Broward county-wide integrated water resource plan report: Broward County, 156 p., accessed January 14, 2015, at http://www.broward.org/IWRP /Documents/IntergratedWaterResourcePlan.pdf.
Decker, J.D., 2018, MODFLOW 2005 data sets for the simulation of potential increased inundation in flood-prone regions of Southeast Florida in response to climate and sea-level changes in Broward County, Florida, 2060-69: U.S. Geological Survey data release, https://dx.doi.org/10.5066/ P9E6INWZ.

Decker, J.D., and Hughes, J.D., 2013, Urban runoff (URO) process for MODFLOW 2005-Simulation of sub-grid scale urban hydrologic processes in Broward County, Florida, in MODFLOW and More 2013-Translating Science into Practice Proceedings: Golden, Colo., Colorado School of Mines, Integrated Groundwater Modeling Center, p. 216-221.

Giddings, J.B., Kuebler, L.L., Restrepo, J.I., Rodberg, K.A., Montoya, A.M., and Radin, H.A., 2006, Lower east coast subregional (LECsR) MODFLOW model documentation: South Florida Water Management District draft report, 213 p., accessed May 19, 2016, at http://www.sfwmd.gov/ portal/page/portal/xrepository/sfwmd_repository_pdf/ lec_sr_draft_documentation.pdf.

Guha, H., and Panday, S., 2012, Impact of sea level rise on groundwater salinity in coastal community of south Florida: Journal of the American Water Resources Association, v. 48, no. 3, p. 510-529.

Harbaugh, A.W., 2005, MODFLOW-2005, The U.S. Geological Survey modular groundwater model-The groundwater flow process: U.S. Geological Survey Techniques and Methods, book 6, chap. A16.

Hughes, J.D., Sifuentes, D.F., and White, J.T., 2016, Simulated effects of alterations to the hydrologic system on the distribution of salinity in the Biscayne aquifer in Broward County, Florida: U.S. Geological Survey Scientific Investigations Report 2016-5022.

Hughes, J.D., and White, J.T., 2014, Hydrologic conditions in urban Miami-Dade County, Florida and the effect of groundwater pumpage and increased sea level on canal leakage and regional groundwater flow: U.S. Geological Scientific Investigations Report 2014-5162, 175 p., accessed August 1, 2018, at http://dx.doi.org/10.3133/ $\operatorname{sir} 20145162$.

Hughes, J.D., Langevin, C.D., Chartier, K.L., and White, J.T., 2012, Documentation of the Surface-Water Routing (SWR1) process for modeling surface-water flow with the U.S. Geological Survey modular groundwater model (MODFLOW-2005): U.S. Geological Survey Techniques and Methods, book 6, chap. A40.

Intergovernmental Panel on Climate Change (IPCC), 2007, Climate change 2007-Synthesis report in Core Writing Team, Pachauri, R.K., and Reisinger, A., eds., Contribution of working groups I, II and III to the Fourth Assessment Report of the Intergovernmental Panel on Climate Change: IPCC, Geneva, Switzerland, 104 p. 
Islam, N., and Dunn, D., 2006, Recalibration and consolidation of integrated surface water and groundwater models for Broward County: Broward County Environmental Protection Department, Water Resources Division, $40 \mathrm{p}$.

Langevin, C.D., and Zygnerski, M., 2013, Effect of sea-level rise on saltwater intrusion near a coastal well field in south-eastern Florida: Ground Water, v. 51, no. 5, p. 781-803.

Langevin, C.D.; Thorne, D.T., Jr.; Dausman, A.M.; Sukop, M.C.; and Guo, W., 2008, SEAWAT version 4-A computer program for simulation of multi-species solute and heat transport: U.S. Geological Survey Techniques and Methods, book 6, chap. A22, 39 p.

Renken, R.A., Dixon, J., Koehmstedt, J., Lietz, A.C., and others, 2005, Impact of anthropogenic development on coastal ground-water hydrology in southeastern Florida, 1900-2000: U.S. Geological Survey Circular 1275, 77 p.

Stefanova, L., Misra, V., Chan, S.C., Griffin, M., O’Bren, J.J., and Smith T.J., 2012, A proxy for high-resolution regional reanalysis for the southeast United States-Assessment of precipitation variability in dynamically downscaled reanalyses: Climate Dynamics, v. 38, p. 2449-2466, accessed July 1, 2016, at http://dx.doi.org/10.1007/ s00382-011-1230-y.
Southeast Florida Regional Climate Change Compact Technical Ad hoc Work Group, 2011, A unified sea level rise projection for southeast Florida: Document prepared for the Southeast Florida Regional Climate Change Compact Steering Committee, $27 \mathrm{p}$.

South Florida Water Management District, 2009, 2007 Broward 10-ft DEM in NAVD 1988, Release Version 1, accessed March 8, 2012, at http://sfwmd.maps.arcgis.com/ home/item.html?id=98b7f5def64345a3a7060b21b500def5.

Telis, P.A., 2006, The Everglades Depth Estimation Network (EDEN) for support of ecological and biological assessments: U.S. Geological Survey Fact Sheet 2006-3087, 4 p.

U.S. Army Corps of Engineers (USACE), 2011, Water Resources Policies and Authorities Incorporating Sea-Level Change Considerations in Civil Works Programs, EC 1165-2-211, U.S. Army Corps of Engineers, Department of Army, Washington, D.C.

U.S. Census Bureau, 2018, Annual estimates of the resident population-April 1, 2010 to July, 2017: U.S. Census Bureau website accessed September 19, 2018, at https:/factfinder.census.gov/faces/tableservices/jsf/pages/ productview.xhtml? $\mathrm{src}=\mathrm{CF}$.

U.S. Department of Agriculture, Natural Resource Conservation Service, 2007, Part 630-Hydrology, in National Engineering Handbook: Washington D.C., U.S. Department of Agriculture. 

Appendixes 1-3 


\section{Appendix 1. Simulated Groundwater Response to Individual Precipitation Events}

The local-scale groundwater/surface-water model was used to evaluate the response of groundwater levels and potential for inundation to individual precipitation events for historical and projected wetter climate conditions for both high and low sea-level rise scenarios. A measured precipitation event that occurred on November 15, 1994, was used to evaluate the response of groundwater levels for historical conditions. Comparing the measured groundwater levels to simulated levels during the same time period demonstrates the local-scale model's ability to capture the effect of precipitation on the groundwater levels. The measured groundwater levels are displayed with the measured precipitation from the nearest rainfall gauge used to create the historical scenario input, while the simulated groundwater levels are displayed with the historical scenario precipitation input data (fig. $1.1 A-F$ ). The averaging method used to create the historical scenarios' precipitation input tends to spatially, and sometimes temporally, smooth out localized precipitation events; therefore, the model data precipitation inputs often have lower maximums but more frequent non-zero values. The precipitation in the easternmost (coastal) areas during this selected time period had a maximum rainfall of 3.1 and 5.0 inches (in.) for the model data input and measured data, respectively (fig. 1.1E, F), and the simulated and measured groundwater levels showed similar trends. The simulated groundwater levels have a lower peak and occur later than the measured groundwater levels, which could be attributed to spatial and temporal resolution and spatially averaged groundwater levels calculated in numerical models, as well as the average precipitation model input. The greatest magnitude of measured and model input precipitation occurs at the westernmost site, G-617 (fig. 1.1A, $B$ ), but the simulated groundwater response is lower and later than measured, compared with sites G-1221 and G-561.

The local-scale model was then used to analyze the simulated groundwater levels following two different precipitation events within the wetter-future Community Climate System Model scenarios. The wetter future, projected-precipitation time series in the easternmost (coastal) climate model cell within the local-scale model was used to identify two representative events. The first precipitation event had a maximum daily total of 3.4 in. projected to occur hypothetically on August 16, 2068 (fig. 1.2A-C). The second event was more extreme, with a maximum daily rainfall of 14.6 in. projected to occur on April 4, 2066 (fig. 1.3C). It is important to note that these dates are representative of hypothetical conditions that could occur during projected future climate conditions and are not intended to represent a prediction of actual events occurring on these dates.

The resulting groundwater effects from these two precipitation model inputs show similar increases during both the high sea-level rise and low sea-level rise scenarios (fig. 1.2). The differences between the minimum and maximum daily groundwater levels, or the rises in groundwater levels, during this time period for the westernmost well, G-617, are 0.39 and 0.67 foot (ft) for the low and high sea-level rise scenarios, respectively (fig. 1.2A). The groundwater-level rise values during the 2060-69 future simulation period at G-1221 were similar for both sea-level rise scenarios, with changes of 0.665 and $0.667 \mathrm{ft}$ for the low and high sea-level rise scenarios, respectively (fig. 1.2B). Lastly, the groundwater-level rises were 1.58 and $1.43 \mathrm{ft}$ at the easternmost well, G-561, for the low and high sea-level rise scenarios, respectively (fig. 1.2C). The high sea-level rise scenario tended to reach the maximum groundwater levels later when compared to the low sea-level rise scenario. This remained true even at G-561 where the groundwater-level rise for the high sea-level rise scenario $(1.43 \mathrm{ft})$ was less than that of the low sea-level rise scenario (1.58 ft; fig. 1.2C).

The groundwater-level rises during the more extreme precipitation event on April 4, 2066, were higher (fig. 1.3) than those for the previously described event on August 16, 2068. At G-617, the high sea-level rise scenario exhibited a larger groundwater-level rise, with an increase of $2.1 \mathrm{ft}$ compared to $1.5 \mathrm{ft}$ occurring during the low sea-level rise scenario (fig. 1.3A). The maximum simulated groundwater level for G-617 of $3.95 \mathrm{ft}$ above the North American Vertical Datum of 1988 (NAVD 88) and a land elevation of $4.98 \mathrm{ft}$ above NAVD 88 resulted in a minimum depth to water of $1.03 \mathrm{ft}$ for the high sea-level rise scenario during this time period. The groundwater-level rises at $\mathrm{G}-1221$ were changes of 2.45 and $2.27 \mathrm{ft}$ for the low and high sea-level rise scenarios, respectively (fig. $1.3 \mathrm{~B}$ ). The maximum simulated groundwater level for G-1221 of $3.44 \mathrm{ft}$ above NAVD 88 and a land elevation of $4.82 \mathrm{ft}$ above NAVD 88 resulted in a minimum depth to water of $1.38 \mathrm{ft}$ for the high sea-level rise scenario during this time period. The low sea-level rise scenario produced a larger increase at $\mathrm{G}-561$ (4.9 ft) than the high sea-level rise scenario $(4.4 \mathrm{ft}$; fig. $1.3 \mathrm{C}$ ). The maximum groundwater level during this time period was $6.126 \mathrm{ft}$ above NAVD 88 for the high sea-level rise scenario. The land elevation of the cell containing this well used in the model is $6.86 \mathrm{ft}$ above NAVD 88 , resulting in $0.73 \mathrm{ft}$ depth to water. These maximum groundwater levels were reached later during the high sea-level rise scenario than during the low sea-level rise scenario. In general, the groundwater-level response was more subdued and delayed farther west, which is possibly due to the increased density of drainage features and reduced model input precipitation farther west.

The effects of the larger precipitation event on possible increases in inundation were also assessed. The model cell was designated as "inundated" when the groundwater level exceeded the land-surface elevation. Using this criterion, there were 4.74 square miles $\left(\mathrm{mi}^{2}\right)$ within the local-scale model that became newly inundated because of the precipitation. The maximum depth within these newly inundated areas was $2.18 \mathrm{ft}$ and varied spatially (fig. 1.4). The smaller precipitation event led to only $0.30 \mathrm{mi}^{2}$ of newly inundated areas. 


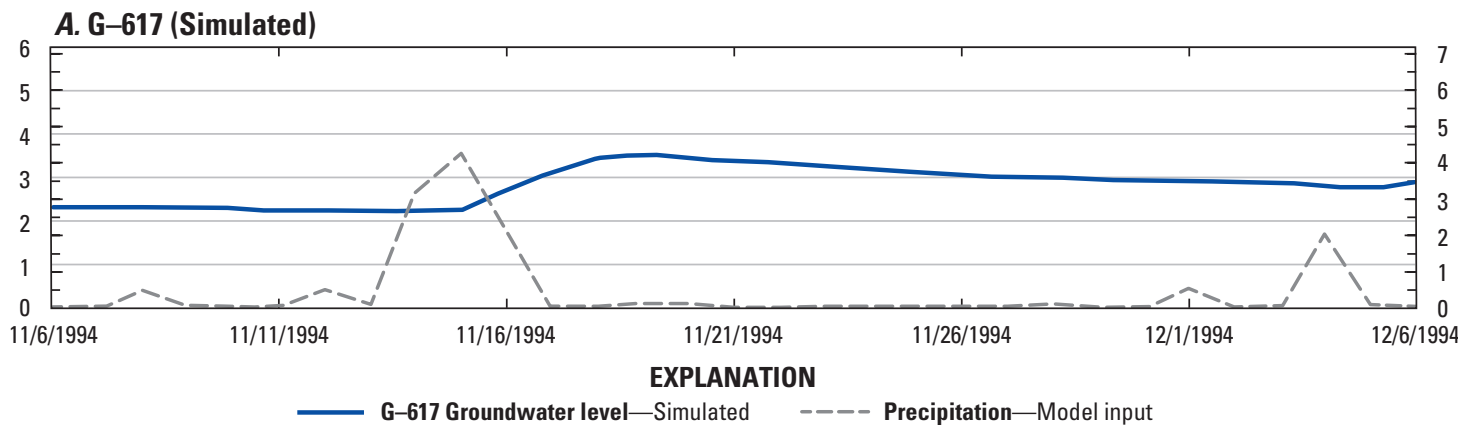

B. G-617 (Measured)

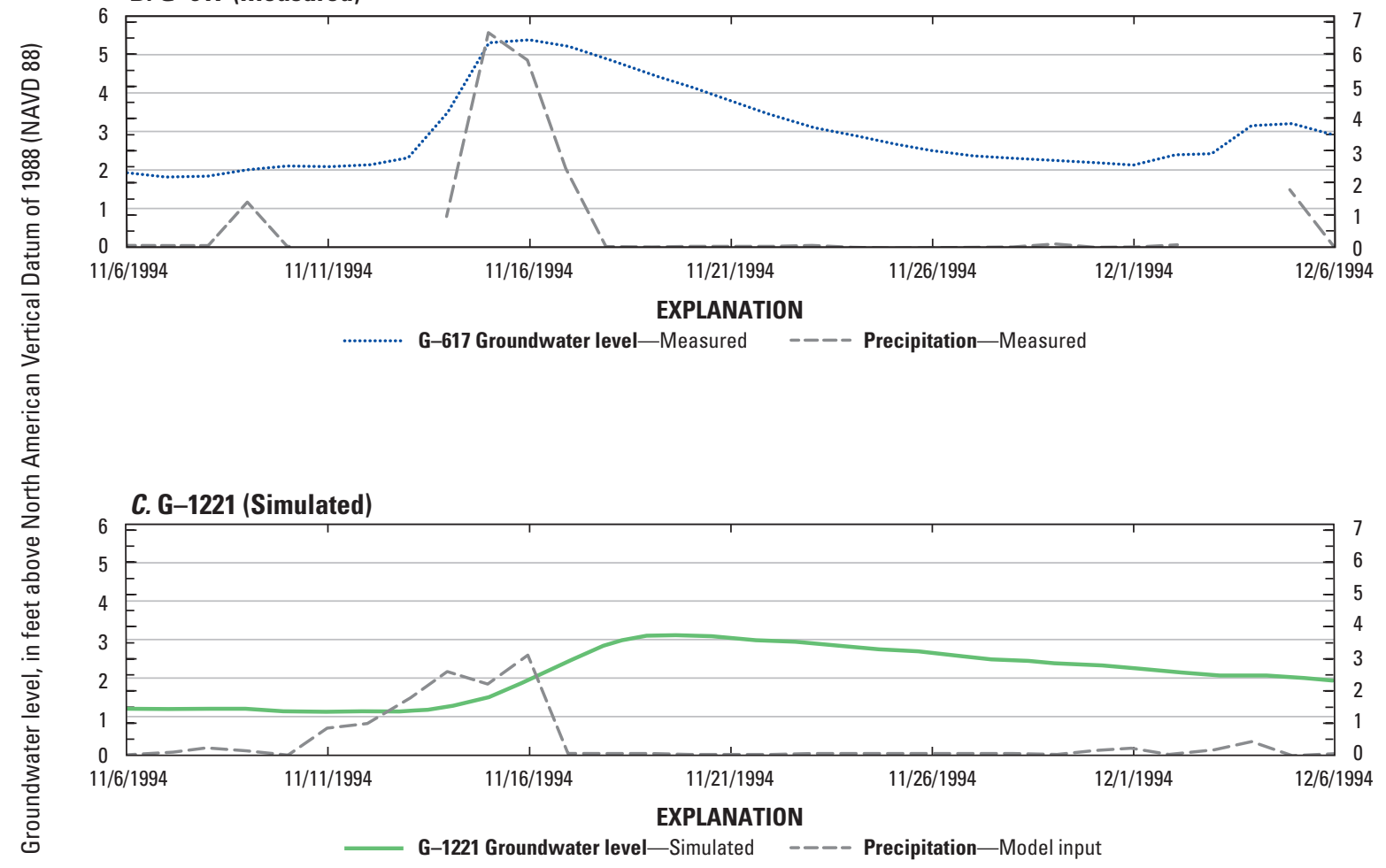

\section{G-1221 (Measured)}

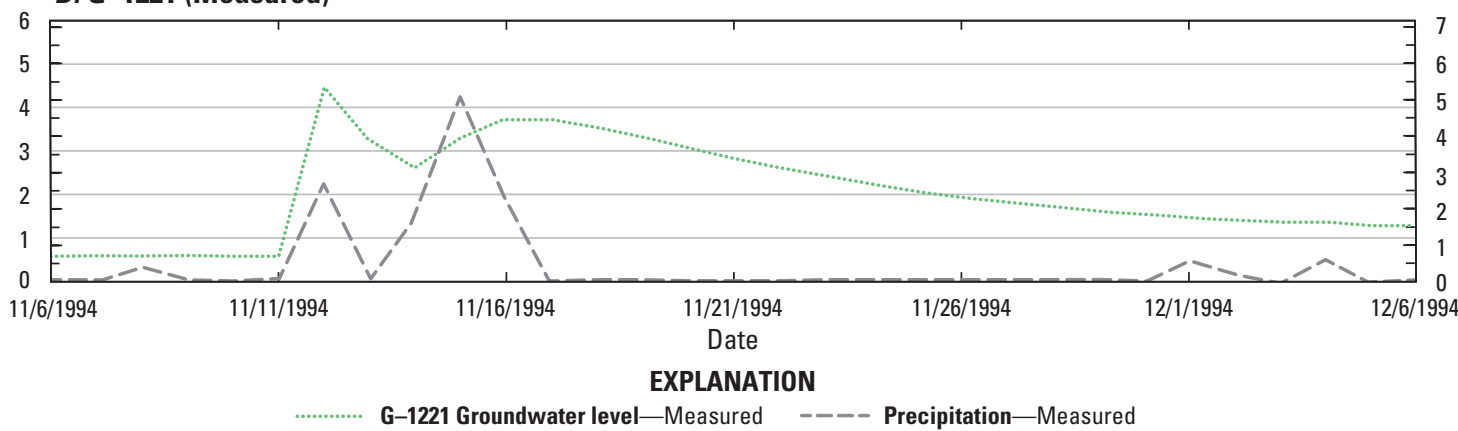

Figure 1.1. Simulated and measured groundwater levels at three groundwater stations $(A, B, \mathrm{G}-516$; $C, D, \mathrm{G}-1221$; and $E, F, \mathrm{G}-617)$ preceding and following a precipitation event. 


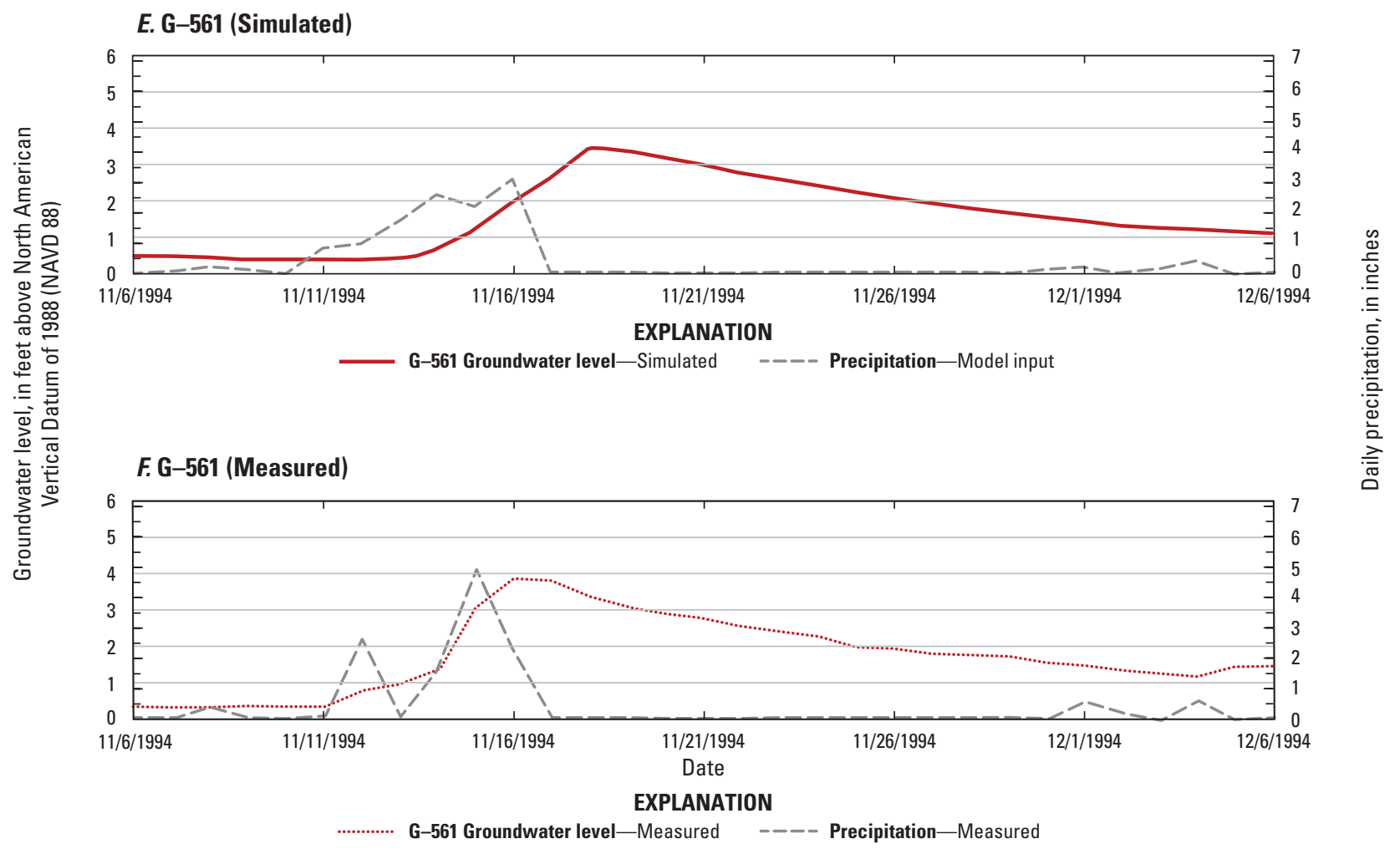

Figure 1.1. Simulated and measured groundwater levels at three groundwater stations $(A, B, \mathrm{G}-516$; $C, D, \mathrm{G}-1221$; and $E, F, \mathrm{G}-617)$ preceding and following a precipitation event.-Continued 


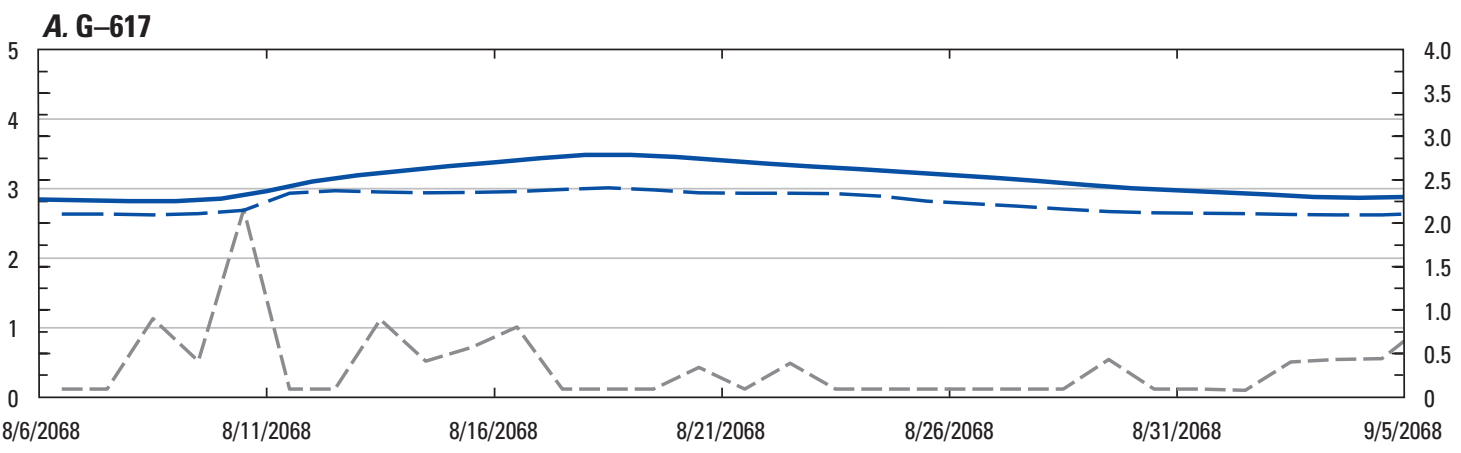

EXPLANATION

G-617 Simulated groundwater level

_- High sea-level rise

- Low sea-level rise

--- Precipitation

\section{B. G-1221}

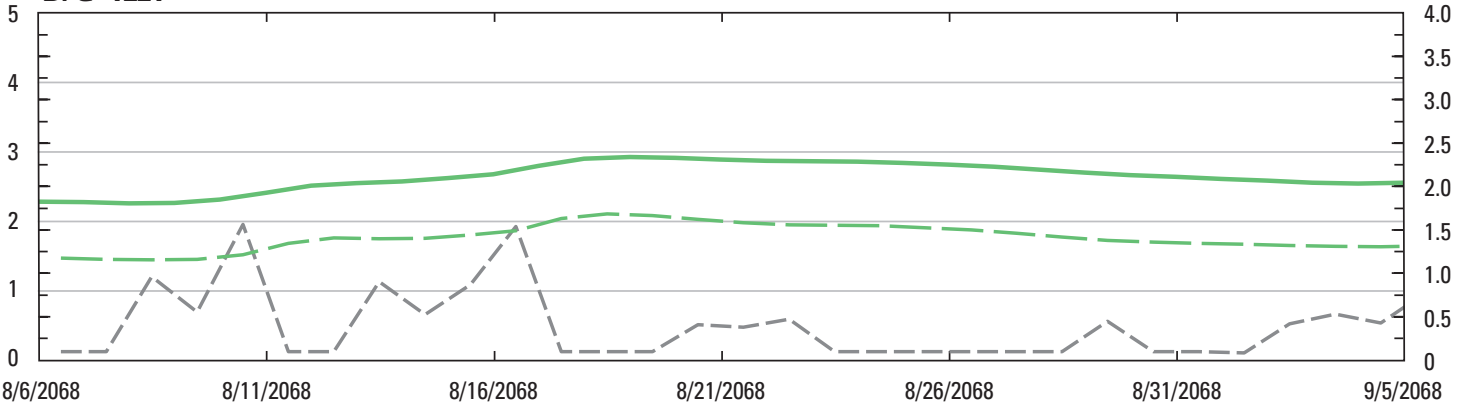

EXPLANATION

G-1221 Simulated groundwater level

- High sea-level rise

- Low sea-level rise

--- Precipitation

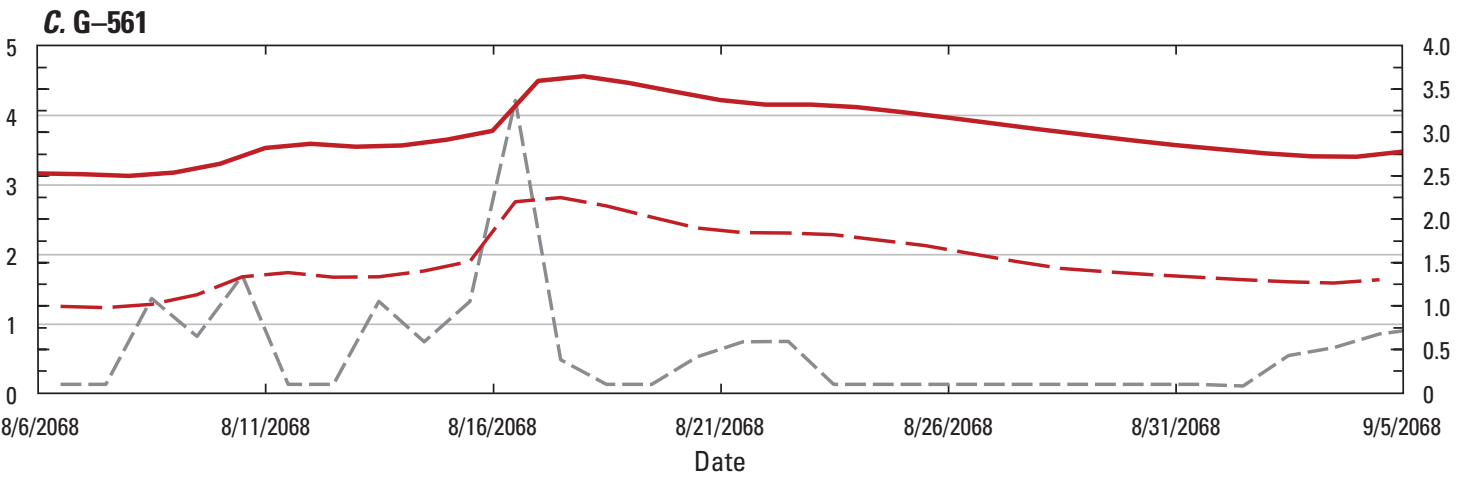

EXPLANATION

G-561 Simulated groundwater level

High sea-level rise
Low sea-level rise
$-\ldots-$ Precipitation

Figure 1.2. Simulated groundwater levels at three groundwater stations $(A, \mathrm{G}-617 ; B, \mathrm{G}-1221$; and $C$, G-516) preceding and following a 3.4-inch daily precipitation event. 

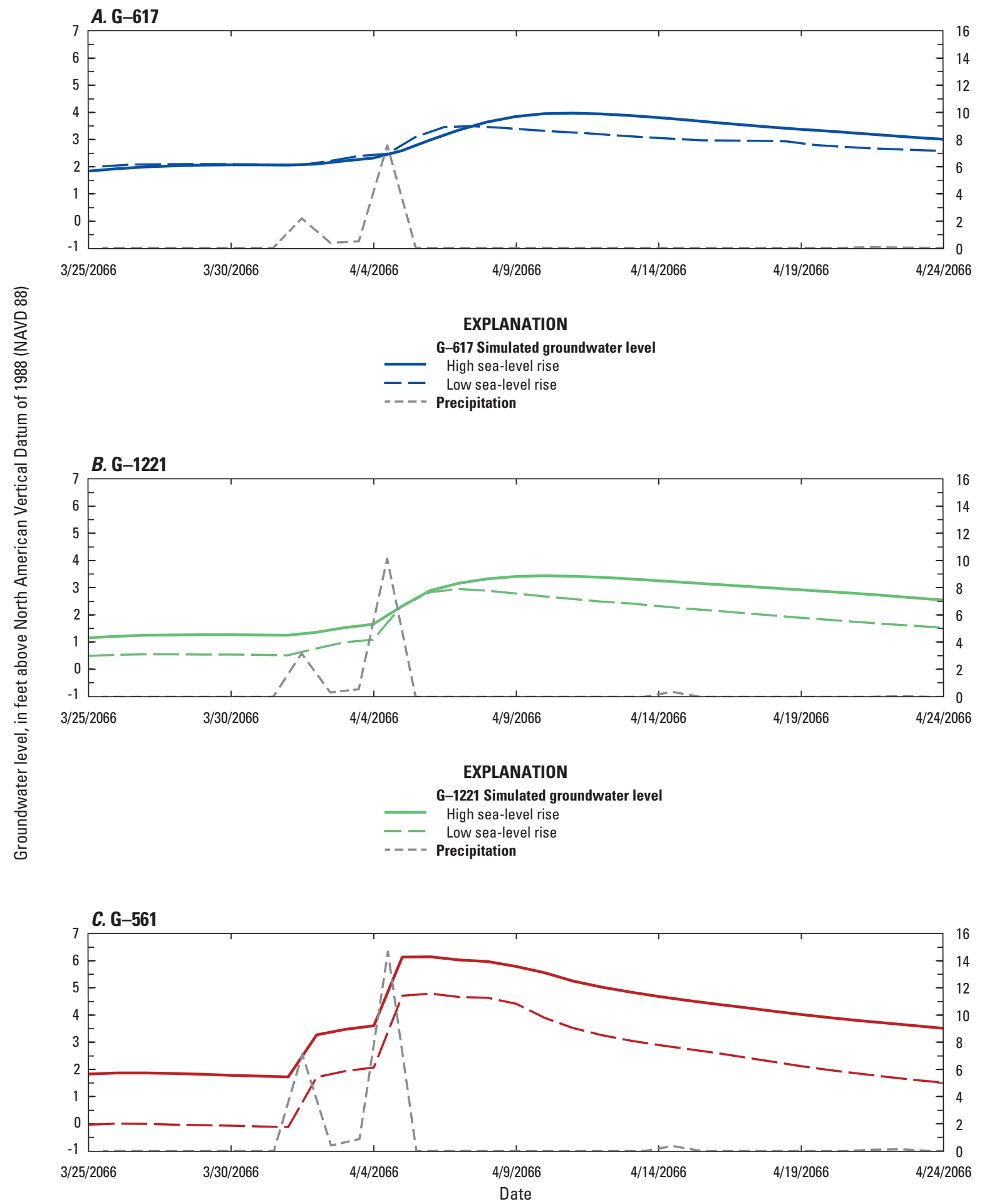

EXPLANATION

G-561 Simulated groundwater level

_ High sea-level rise

- - Low sea-level rise

- - - - Precipitation

Figure 1.3. Simulated groundwater levels at three groundwater stations $(A, \mathrm{G}-617 ; B, \mathrm{G}-1221$; and $C$, G-516) preceding and following a 14.6-inch daily precipitation event. 

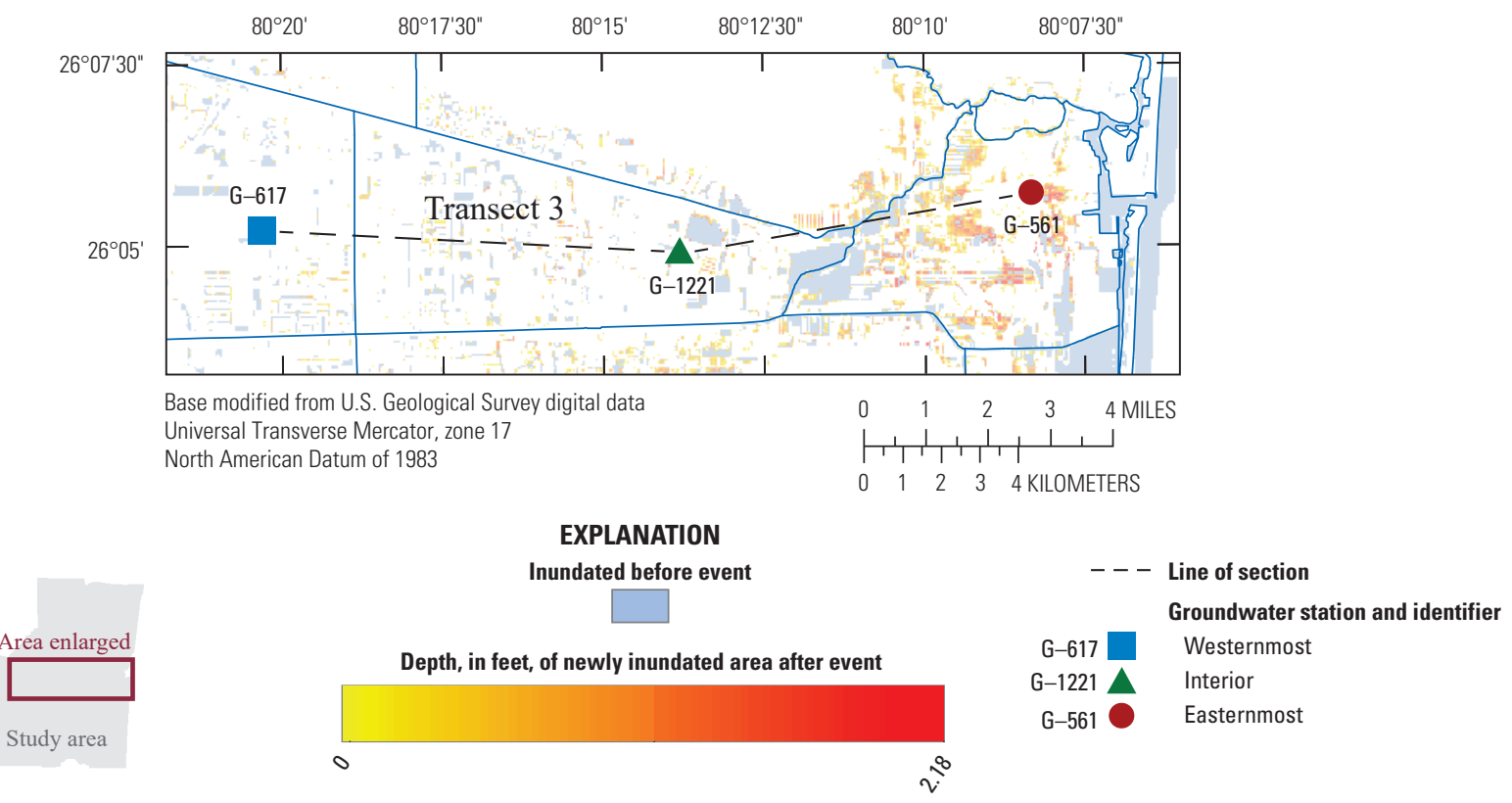

Figure 1.4. Depth of newly inundated areas following a 14.6-inch daily precipitation event. 


\section{Appendix 2. Numerical Model Construction}

\section{County-Scale Numerical Model Construction}

The variable-density flow model developed for central and southern Broward County (Hughes and others, 2016), henceforth called the "saltwater-intrusion model," was used as the basis to construct the county-scale model. The saltwater-intrusion model was the primary source for the extent, discretization, and the calibrated hydrologic parameters used for the county-scale model. This section documents the construction of the county-scale model and describes in detail the parts of the model that were modified from the saltwater-intrusion model. The study's associated data release contains the input files described herein as well as the required executables to reproduce simulation results (Decker, 2018).

\section{Extent and Discretization}

The county-scale model extent was unchanged from the central and southern Broward County saltwater-intrusion model. The spatial discretization was maintained at 500 feet (ft) by $500 \mathrm{ft}$ for all 411 rows and 501 columns. The original saltwater-intrusion model was vertically discretized into 12 layers by using a combination of lithostratigraphic and hydrogeologic models for the surficial aquifer. During the calibration of that model, these 12 layers were redistributed and assigned to 3 layers: (1) the upper (UPR), (2) production (PRD), and (3) lower (LWR) model layers. These three designations are described in detail in Hughes and others (2016). Layers 1 and 2 are combined into the UPR layer, layers 3-10 are combined to form the PRD layer, and layers 11 and 12 represent the LWR layer. The model consists of 50,179 active cells per vertical layer for a total of 150,537 active groundwater cells covering a spatial extent of 450 square miles $\left(\mathrm{mi}^{2}\right)$.

The simulation period for the original saltwater-intrusion model was from January 1, 1950, to May 31, 2012, and used a monthly MODFLOW 2005 stress period and time step. The base-case and historical simulation periods were shortened to January 1, 1990, to December 31, 1999, and used a daily MODFLOW stress period and hourly time steps to obtain better temporal resolution. Fifteen-minute time steps are used for the Surface-Water Routing (SWR1) and Urban Runoff (URO) processes. Shortened MODFLOW time steps reduced the number of outer MODFLOW iterations and overall run times of the model because of the implicit coupling of the URO and SWR1 processes. The future simulation period represents predicted values of sea-level rise and climate forcing for January 1, 2060, to December 31, 2069. The stress period and time-step lengths remain the same as with the base-case and historical simulations.

\section{Land Surface and Layer-Bottom Elevations}

The top of layer 1, which corresponds to land surface, ranged from -1.98 to $20 \mathrm{ft}$ above North American Vertical Datum of 1988 (NAVD 88), with an average elevation of $6.24 \mathrm{ft}$ above NAVD 88 (fig. 2.1). These values are the same land-surface elevations found within the central and southern Broward County saltwater-intrusion model, which was developed by using 3-ft resolution light detection and ranging (lidar) data (Hughes and others, 2016). The saltwater-intrusion model layer-bottom elevations from layers 2, 10, and 12 were used for the bottoms of the three layers of the county-scale model (figs. 2.2 to 2.4). The elevations of the bottom of layer 1 varied between $-71.81 \mathrm{ft}$ and $-22.83 \mathrm{ft}$ above NAVD 88, with an average elevation of $-50.34 \mathrm{ft}$ above NAVD 88 . The elevations of the bottom of layer 2 varied between -137.83 and $-48.58 \mathrm{ft}$ above NAVD 88, with an average elevation of $-103.64 \mathrm{ft}$ above NAVD 88. The elevations of the bottom of layer 3 varied between -319.28 and $-193.22 \mathrm{ft}$ above NAVD 88, with an average elevation of $-248.29 \mathrm{ft}$ above NAVD 88.

\section{Hydraulic Parameters}

The hydraulic parameters used for the county-scale model were calculated by using the calibrated parameters from the saltwater-intrusion model (Hughes and others, 2016). The properties of layers 1 and 2, 3-10, and 11 and 12 were averaged to produce the county-scale model parameter fields for layers 1,2 , and 3 , respectively.

\section{Horizontal and Vertical Hydraulic Conductivity}

The horizontal hydraulic conductivity $\left(K_{h}\right)$ for each layer in the county-scale model was calculated from the 12-layer saltwater-intrusion model by using the layer-thickness weighted arithmetic mean:

$$
K_{h}=\frac{\sum_{i=1}^{n} b_{i} K_{i}}{\sum_{i=1}^{n} b_{i}},
$$

where

$K_{h} \quad$ is the mean horizontal hydraulic conductivity for groundwater cell;

$b_{i} \quad$ is the thickness of layer $i$ within the groundwater cell; and

$K_{i} \quad$ is the horizontal hydraulic conductivity for layer $i$ within the groundwater cell (L/T). 


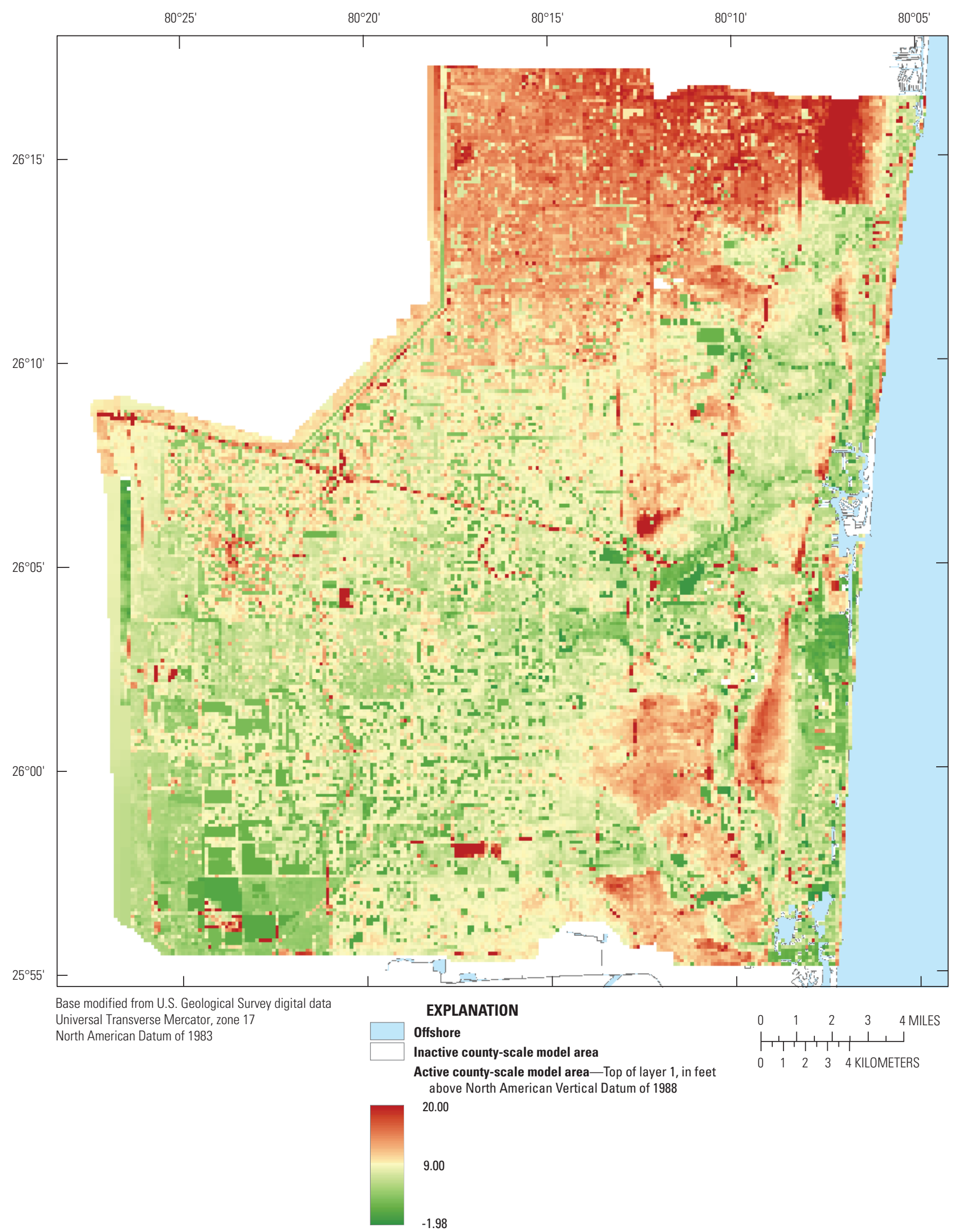

Figure 2.1. County-scale model top of layer 1. 


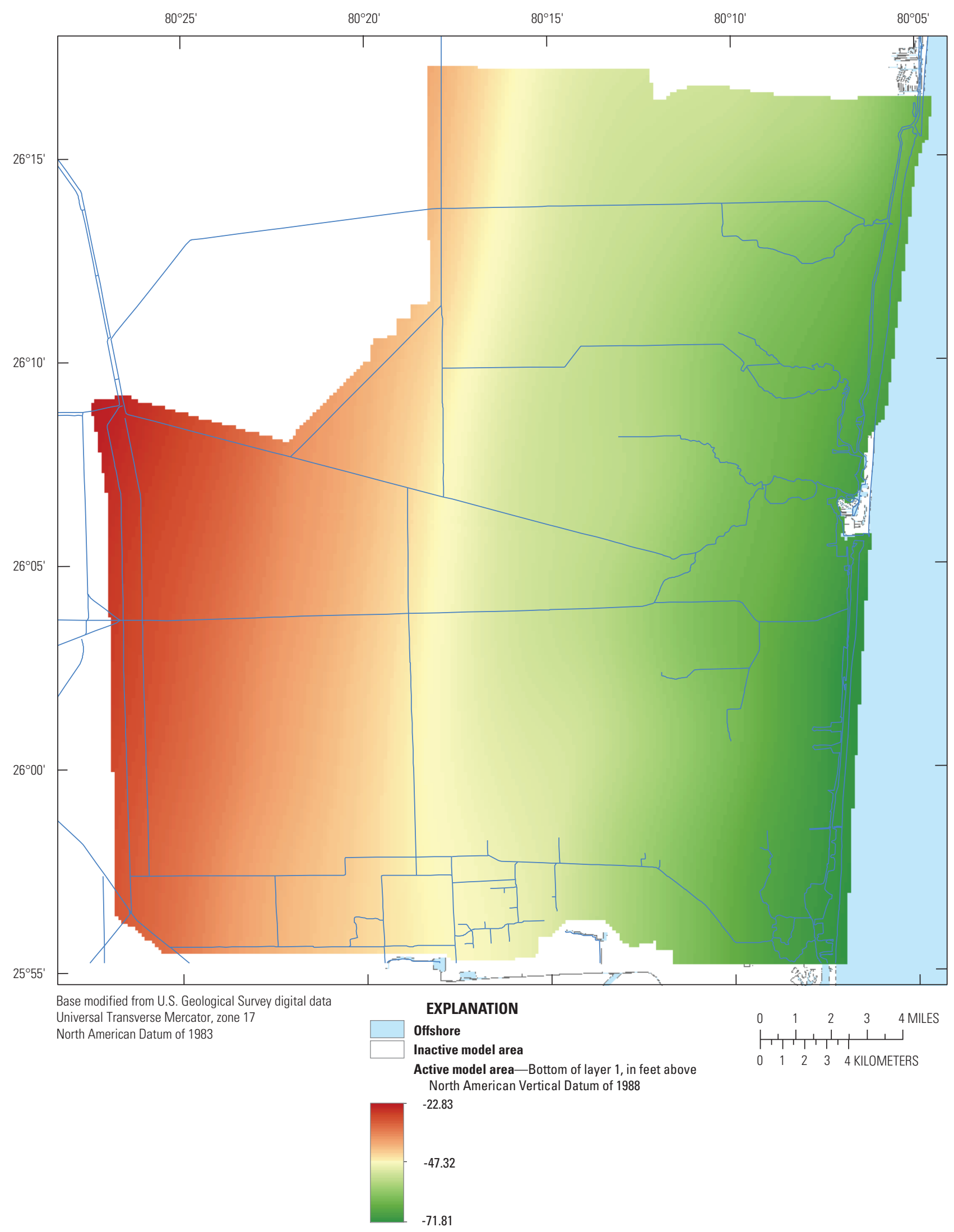

Figure 2.2. County-scale model bottom of layer 1. 


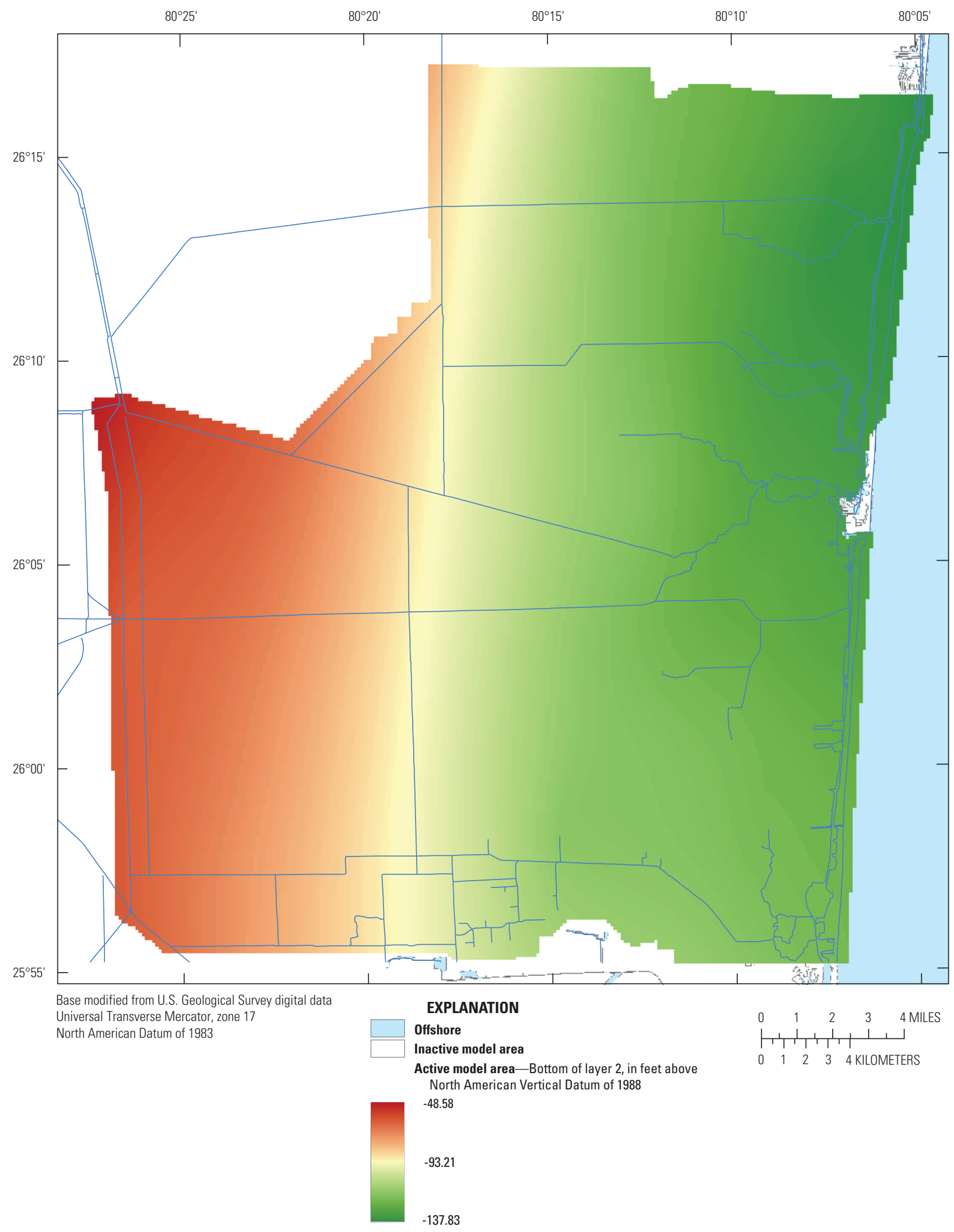

Figure 2.3. County-scale model bottom of layer 2. 


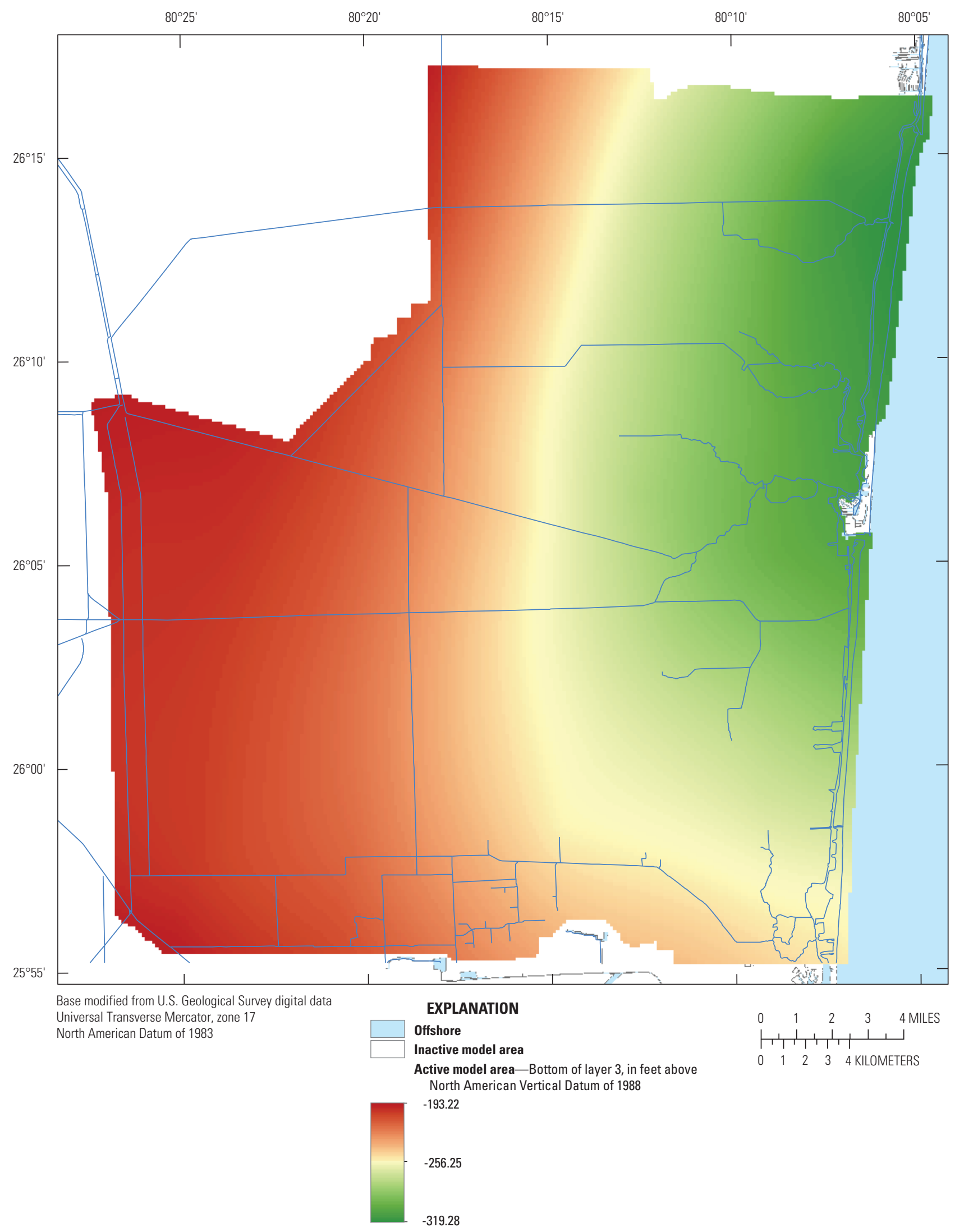

Figure 2.4. County-scale model bottom of layer 3. 
The horizontal hydraulic conductivity in layer 1 varied from 220.5 feet per day (ft/d) to $32,000 \mathrm{ft} / \mathrm{d}$, with an average of $1,905.8 \mathrm{ft} / \mathrm{d}$. The horizontal hydraulic conductivity in layer 2 varied from $245 \mathrm{ft} / \mathrm{d}$ to $29,400 \mathrm{ft} / \mathrm{d}$, with an average of $3,060.3 \mathrm{ft} / \mathrm{d}$. The horizontal hydraulic conductivity in layer 3 varied from $185.5 \mathrm{ft} / \mathrm{d}$ to $25,624 \mathrm{ft} / \mathrm{d}$, with an average of $743.3 \mathrm{ft} / \mathrm{d}$ (figs. 2.5 to 2.7 ).

The vertical hydraulic conductivity $\left(K_{v}\right)$ for each layer in the county-scale model was calculated from the 12-layer saltwater-intrusion model by using the layer-thickness weighted harmonic mean:

$$
K_{v}=\frac{\sum_{i=1}^{n} b_{i}}{\sum_{i=1}^{n} \frac{b_{i}}{K_{v i}}},
$$

where

$$
\begin{gathered}
K_{v} \quad \begin{array}{c}
\text { is the mean vertical hydraulic conductivity for } \\
\text { the groundwater cell }(\mathrm{L} / \mathrm{T}) \text {; and }
\end{array} \\
K_{v i} \quad \text { is the vertical hydraulic conductivity for layer } \\
i \text { within the groundwater cell }(\mathrm{L} / \mathrm{T}) .
\end{gathered}
$$

The vertical hydraulic conductivity in layer 1 varied from $1.1 \mathrm{ft} / \mathrm{d}$ to $39.5 \mathrm{ft} / \mathrm{d}$, with an average of $6.9 \mathrm{ft} / \mathrm{d}$. The vertical hydraulic conductivity in layer 2 varied from $2.0 \mathrm{ft} / \mathrm{d}$ to $21.2 \mathrm{ft} / \mathrm{d}$, with an average of $10.1 \mathrm{ft} / \mathrm{d}$. The vertical hydraulic conductivity in layer 3 varied from $2.8 \mathrm{ft} / \mathrm{d}$ to $9.1 \mathrm{ft} / \mathrm{d}$, with an average of $5.2 \mathrm{ft} / \mathrm{d}$ (figs. 2.8 to 2.10 ).

\section{Specific Yield and Specific Storage}

The specific yield of the top layer, which was specified as convertible, and the specific storage of all three layers used the layer-thickness weighted arithmetic mean from the 12-layer saltwater-intrusion model and the UPR, PRD, and LWR designations. The specific yield for layer 1 ranged from 0.03 to 0.4 , with an average of 0.24 . The specific storage of layer 1 ranged from $6.43 \times 10^{-6}$ to $1.33 \times 10^{-5}$, with an average of $1.03 \times 10^{-5}$. The specific storage of layer 2 ranged from $7.20 \times 10^{-6}$ to $1.21 \times 10^{-5}$, with an average of $1.03 \times 10^{-5}$. The specific storage of layer 3 ranged from $8.65 \times 10^{-6}$ to $1.18 \times 10^{-5}$, with an average of $1.02 \times 10^{-5}$ (figs. 2.11 to 2.14 ).

\section{Head-Dependent Boundaries at Model Extents}

The northern, southern, and western general head boundaries (GHBs) from the saltwater-intrusion models were used for the county-scale model (fig. 1 in main body of report). The western head values were generated by using data from the Everglades Depth Estimation Network (EDEN), whereas the northern and southern head values were calculated by using nearby groundwater-monitoring wells (Hughes and others, 2016). The monthly stress period heads of the saltwater-intrusion model were linearly interpolated to daily stress period values.

\section{Tidal Boundaries}

The county-scale model used MODFLOW GHBs to represent the tidal boundaries (fig. 1 in main body of report). The locations of these boundaries were taken from the saltwater-intrusion model (Hughes and others, 2016). The tidal head values for the historical and base-case simulations were generated from daily averaged tidal measurements from nearby gages when available and estimations using National Oceanic and Atmospheric Administration (NOAA) tide predictions when values were missing. Hourly data from the Haulover Pier tidal station were used for January 1, 1990, to August 31, 1992; NOAA tide predictions for Virginia Key using the NOAA Tide Prediction algorithm (NTP4) were used for September 1, 1992, to January 28, 1994; and hourly measured tide for the Virginia Key tidal station was used for the remainder of the simulation period. Any gaps in measured values were filled with the NOAA tide predictions. When predicted values were used rather than actual measurements, the weather component of the tidal levels was missing, which typically led to reduced daily fluctuations (fig. 2.15).

Three future tidal-level scenarios representing high, intermediate, and low projections were calculated by adding sea-level rise estimates to the historical and base-case tidal GHB levels. The three sea-level rise scenarios were constructed by using an estimated current sea-level rise rate of 2.24 millimeters per year $(\mathrm{mm} / \mathrm{yr})(0.088 \mathrm{inch}$ per year [in/yr] $)$ and the National Research Council (NRC) Curve I and Curve III sea-level rise predictions, which use an acceleration term (b, eq. 6). The NRC projections were calculated by using the equation and methodology described by the U.S. Army Corps of Engineers (USACE, 2011):

$$
E\left(t_{2}\right)-E\left(t_{1}\right)=a\left(t_{2}-t_{1}\right)+b\left(t_{2}^{2}-t_{1}^{2}\right),
$$

where

$E(t) \quad$ is the sea-level rise expected since 1992, in meters;

$t_{1} \quad$ is the time between the projection start date and 1992;

$t_{2} \quad$ is the time between the projection end date and 1992;

$a$ is the local current linear sea-level rise rate, in meters; and

$b \quad$ is a constant depicting the acceleration of sea-level rise.

The current linear rate of sea-level rise $(a)$ used to calculate the NRC predictions was 0.00224 meter per year $(\mathrm{m} / \mathrm{yr})(0.088 \mathrm{in} / \mathrm{yr})$, and the acceleration constants $(b)$ used for Curve I and Curve III predictions were 0.0000271 and 0.000113 , respectively. The resulting projections of sea-level rise from current tidal levels for the beginning and end of the 2060-69 simulation were $0.478 \mathrm{ft}$ and $0.551 \mathrm{ft}$ using the linear rate (low), $0.888 \mathrm{ft}$ and $1.091 \mathrm{ft}$ using NRC Curve I (intermediate), and $2.189 \mathrm{ft}$ and $2.803 \mathrm{ft}$ using the NRC Curve III (high) (fig. 2.15). 


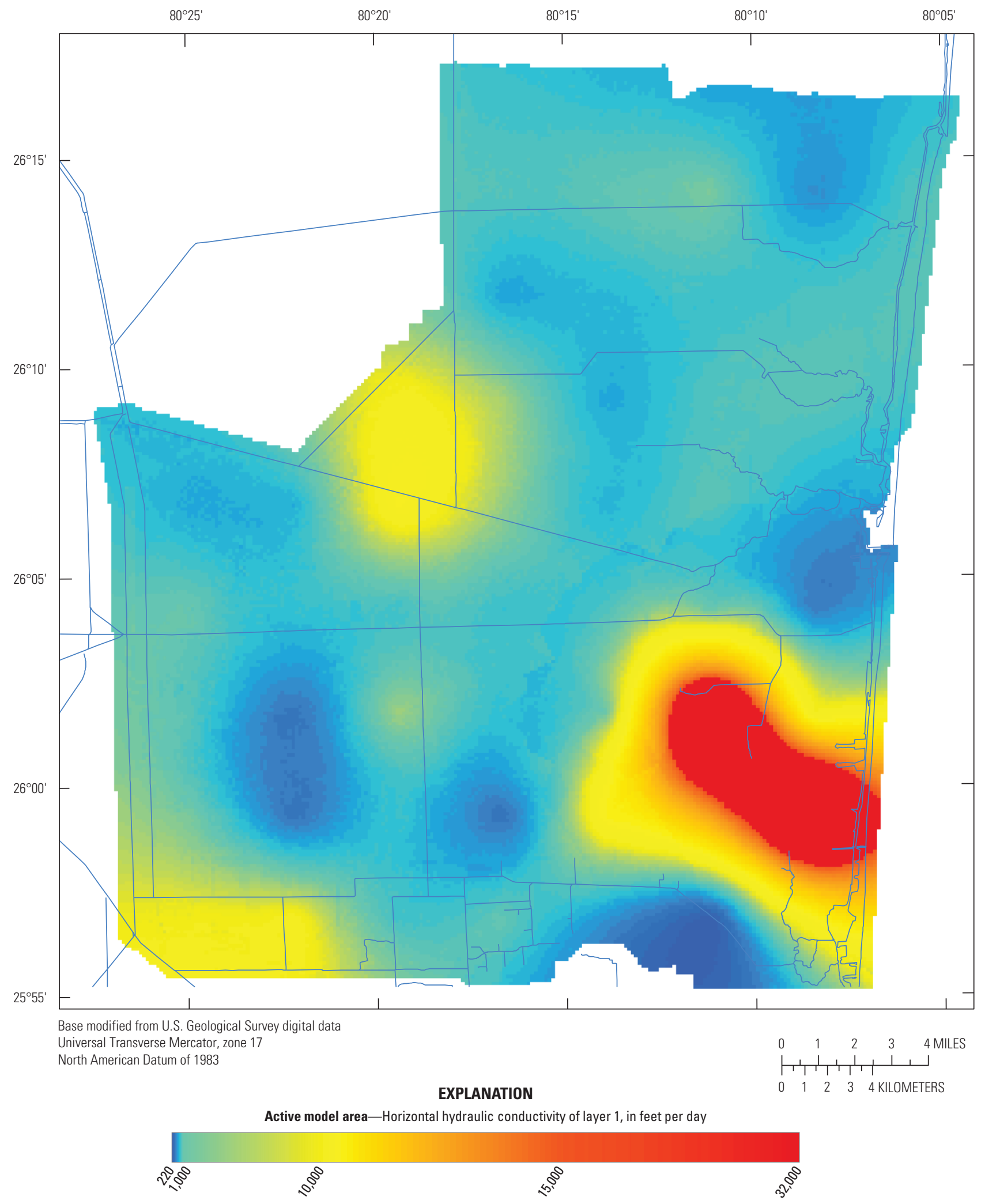

Figure 2.5. Horizontal hydraulic conductivity of layer 1 in the county-scale model. 


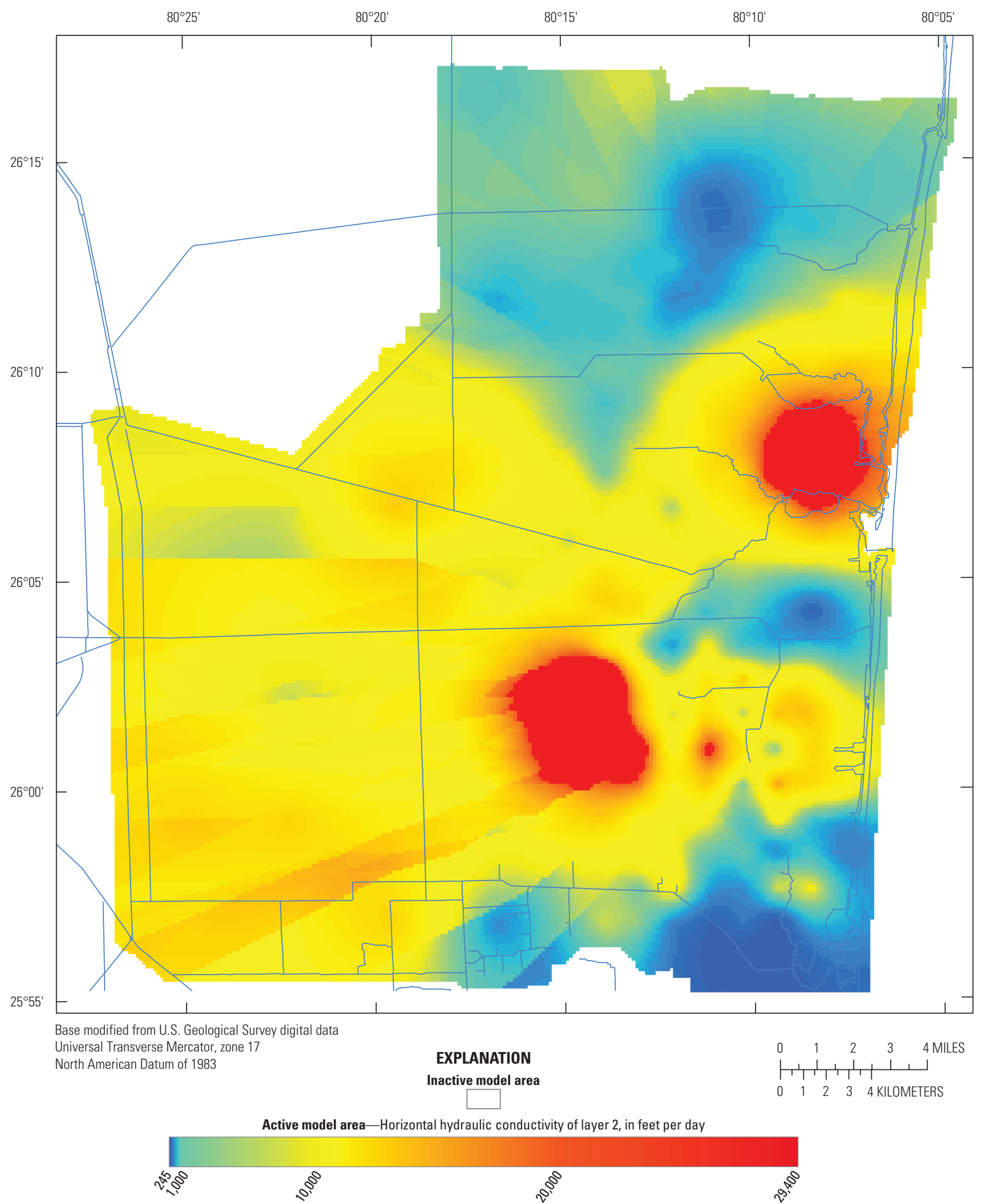

Figure 2.6. Horizontal hydraulic conductivity of layer 2 in the county-scale model. 


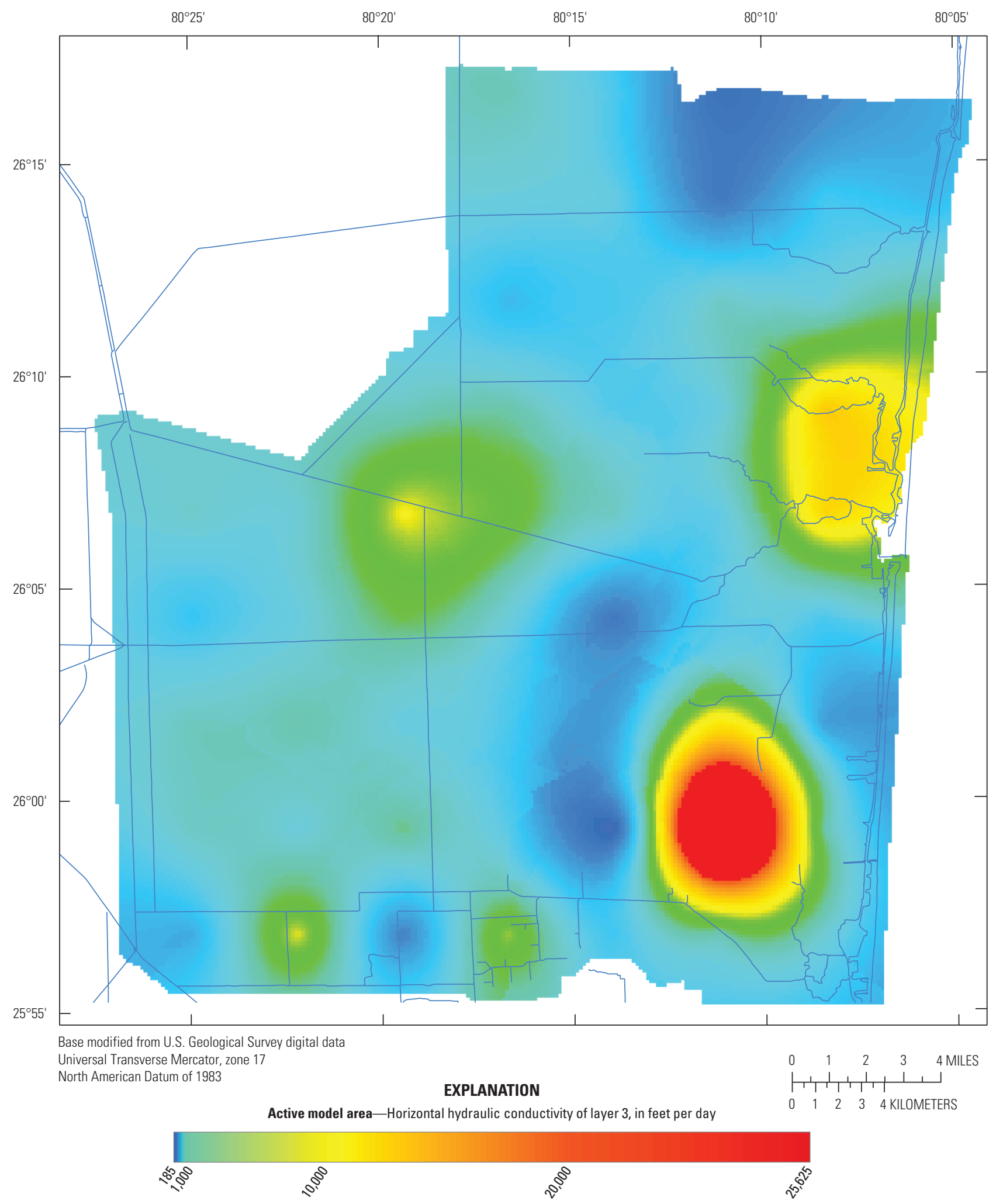

Figure 2.7. Horizontal hydraulic conductivity of layer 3 in the county-scale model. 


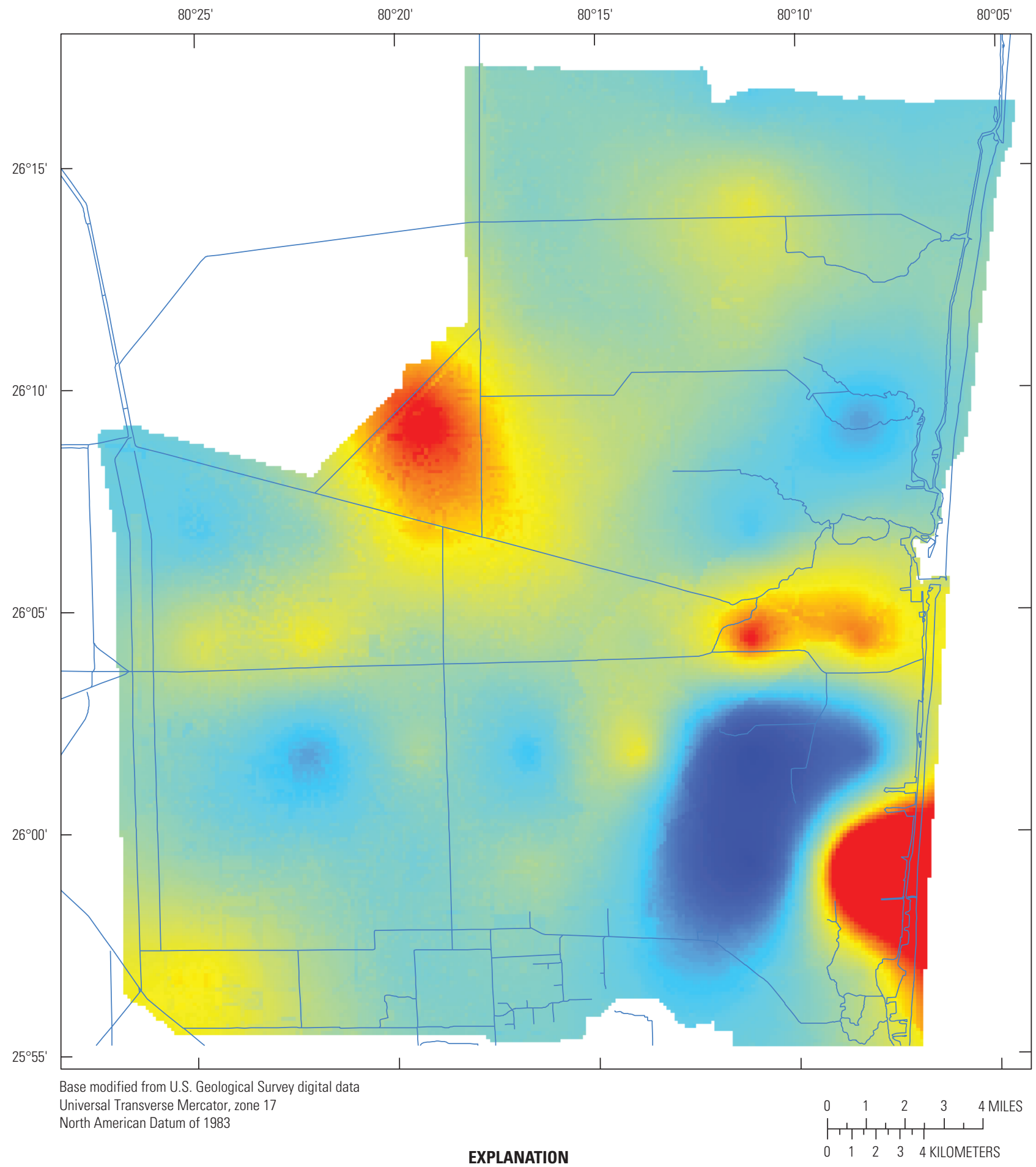

Active model area - Vertical hydraulic conductivity of layer 1 , in feet per day

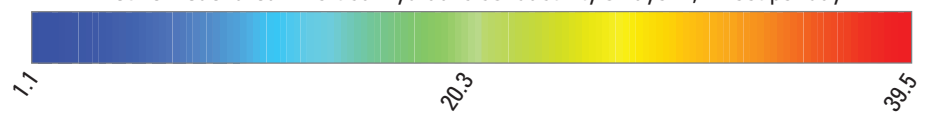

Figure 2.8. Model input showing vertical hydraulic conductivity of layer 1 in the county-scale model. 


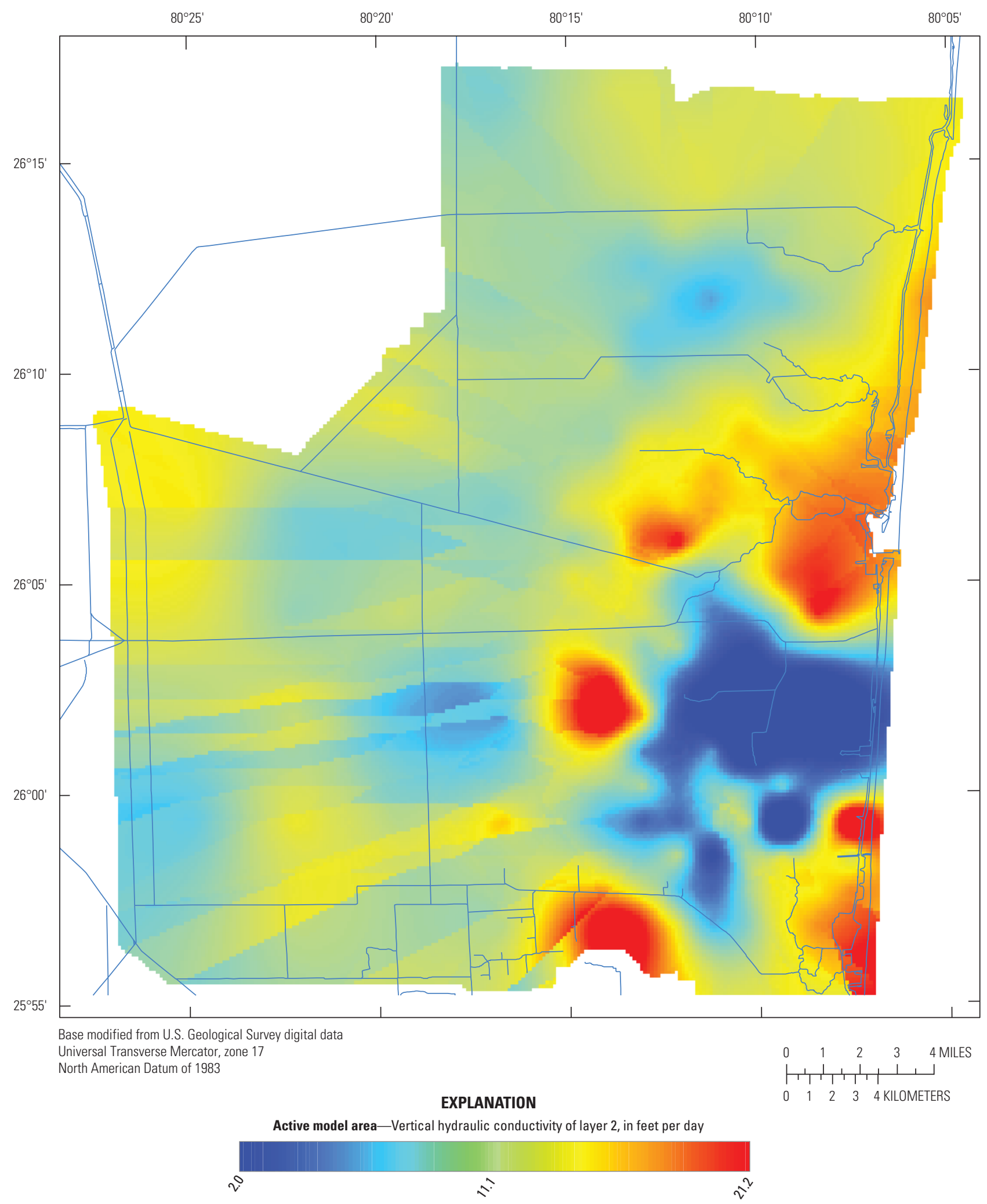

Figure 2.9. Model input showing vertical hydraulic conductivity of layer 2 in the county-scale model. 


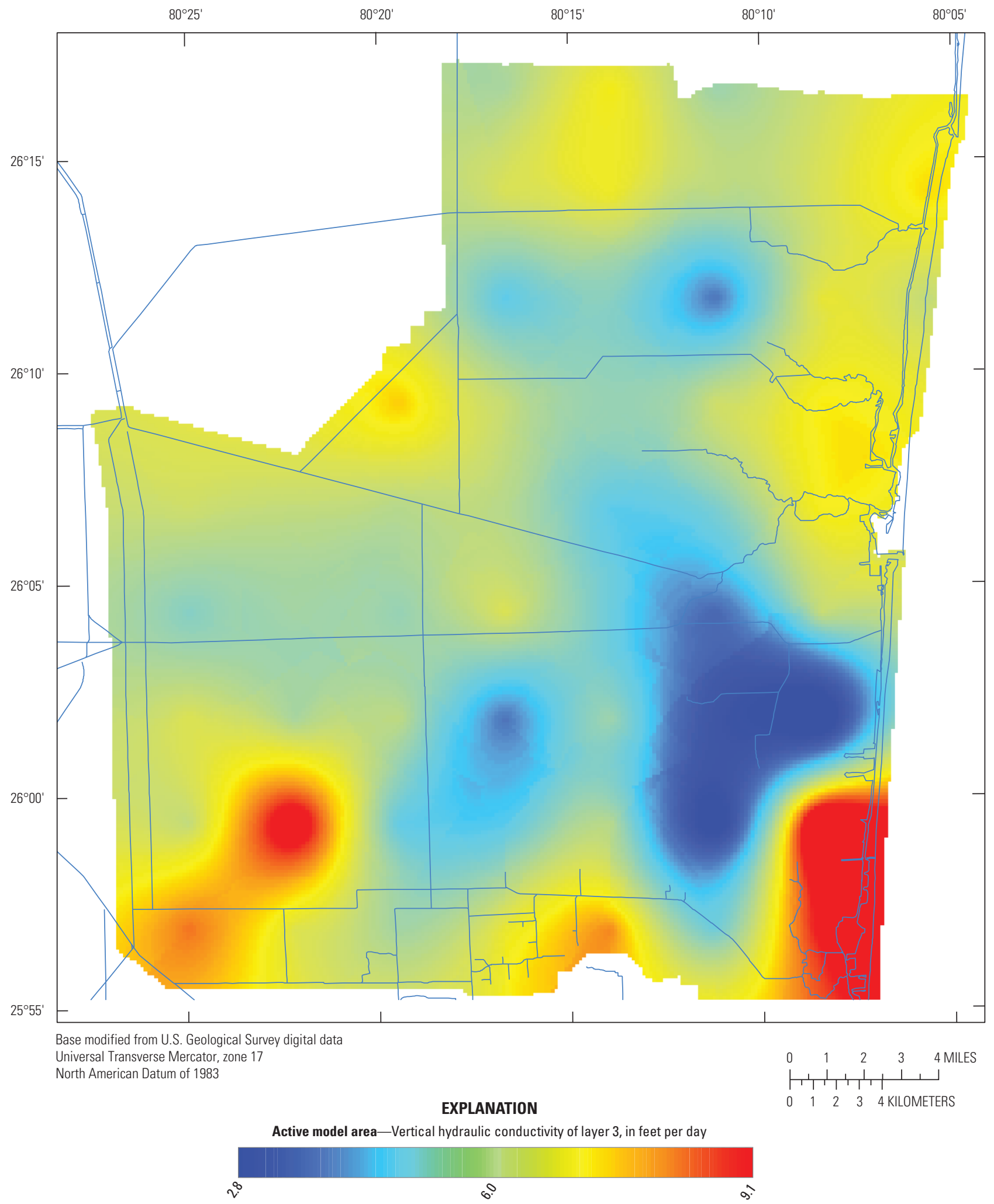

Figure 2.10. Model input showing vertical hydraulic conductivity of layer 3 in the county-scale model. 


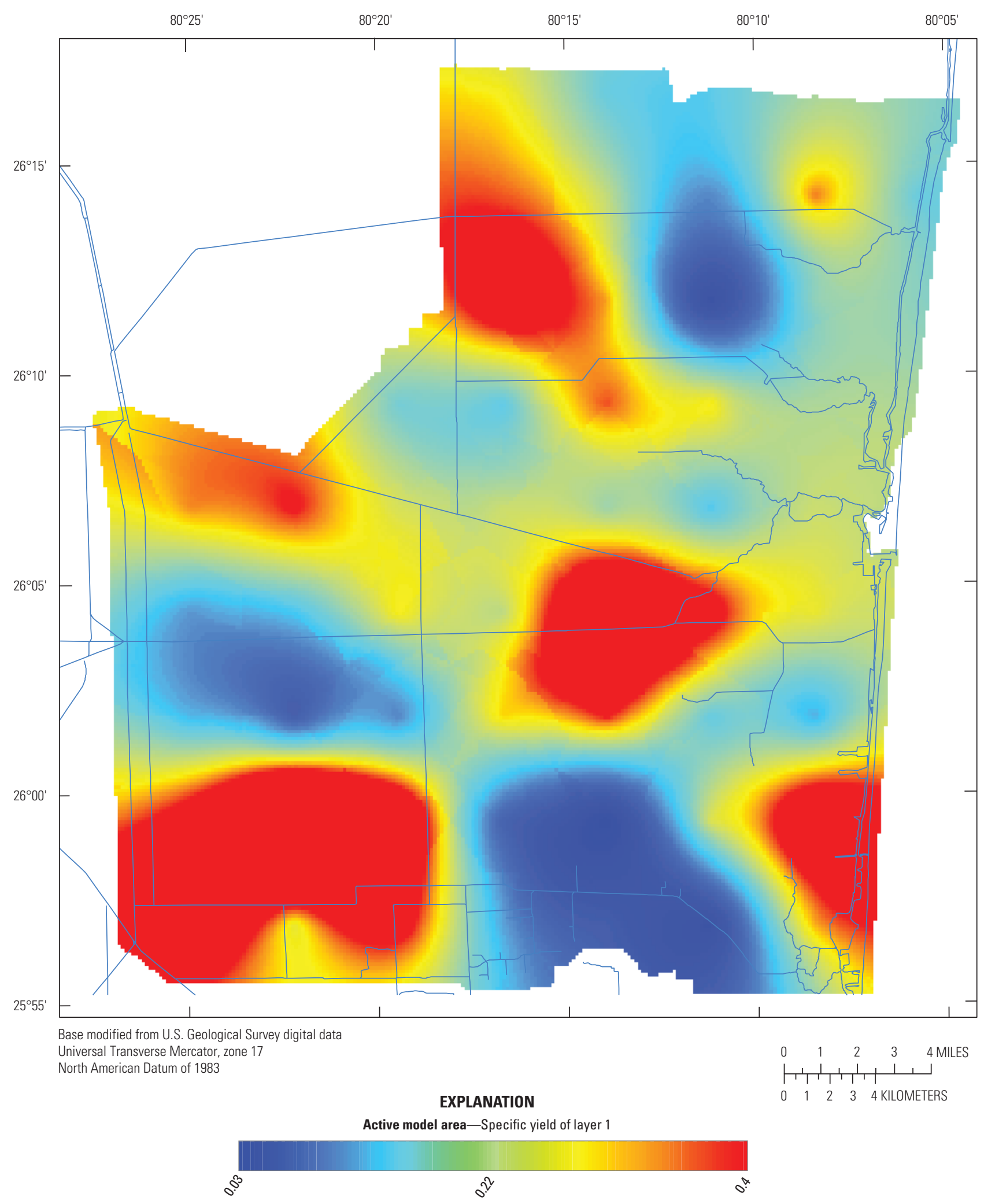

Figure 2.11. Specific yield of layer 1 in the county-scale model. 


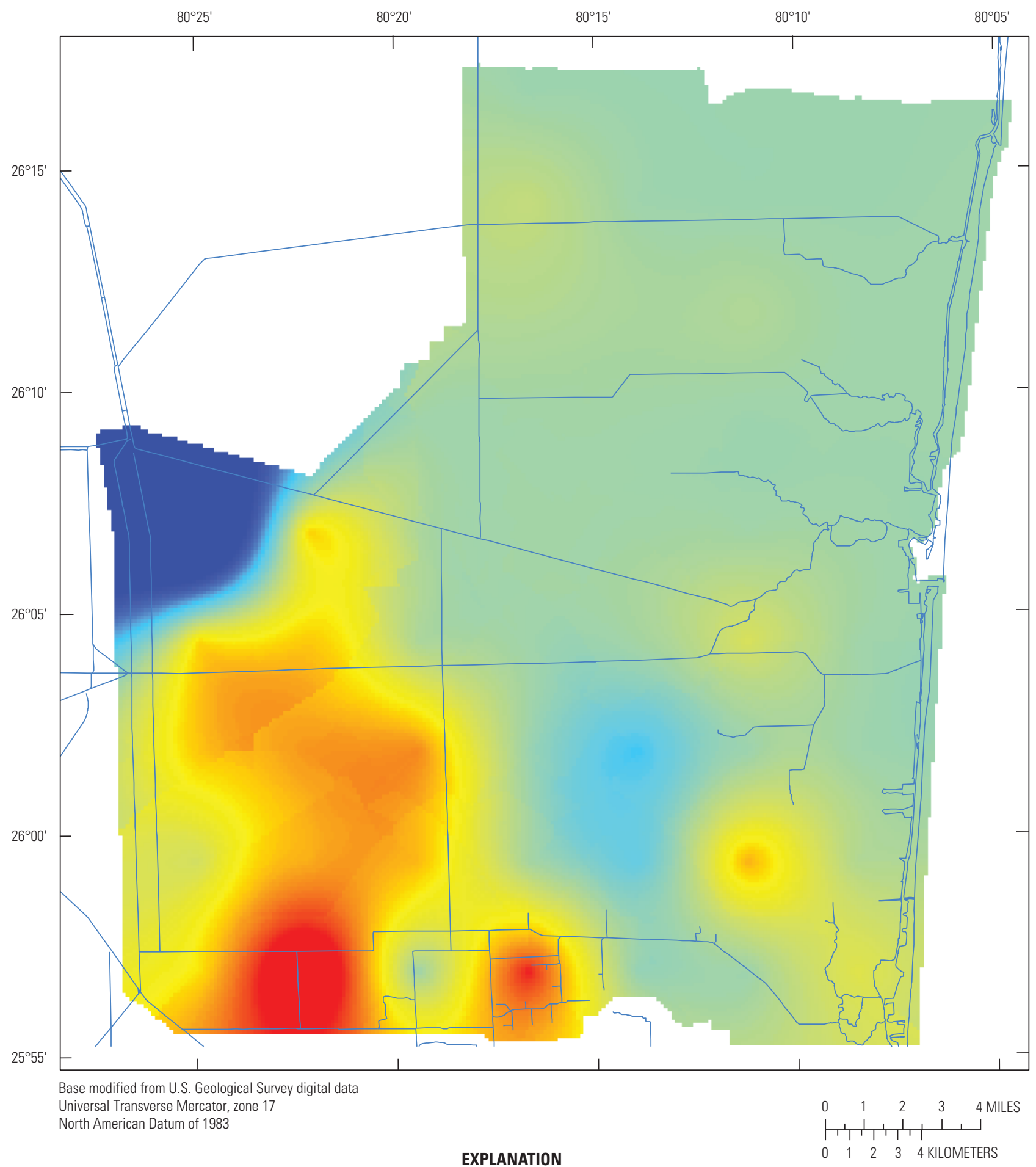

Active model area-Specific storage of layer 1

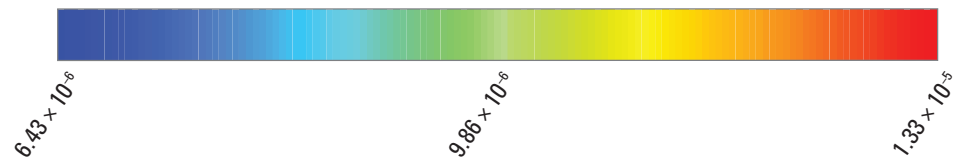

Figure 2.12. Specific storage of layer 1 in the county-scale model. 


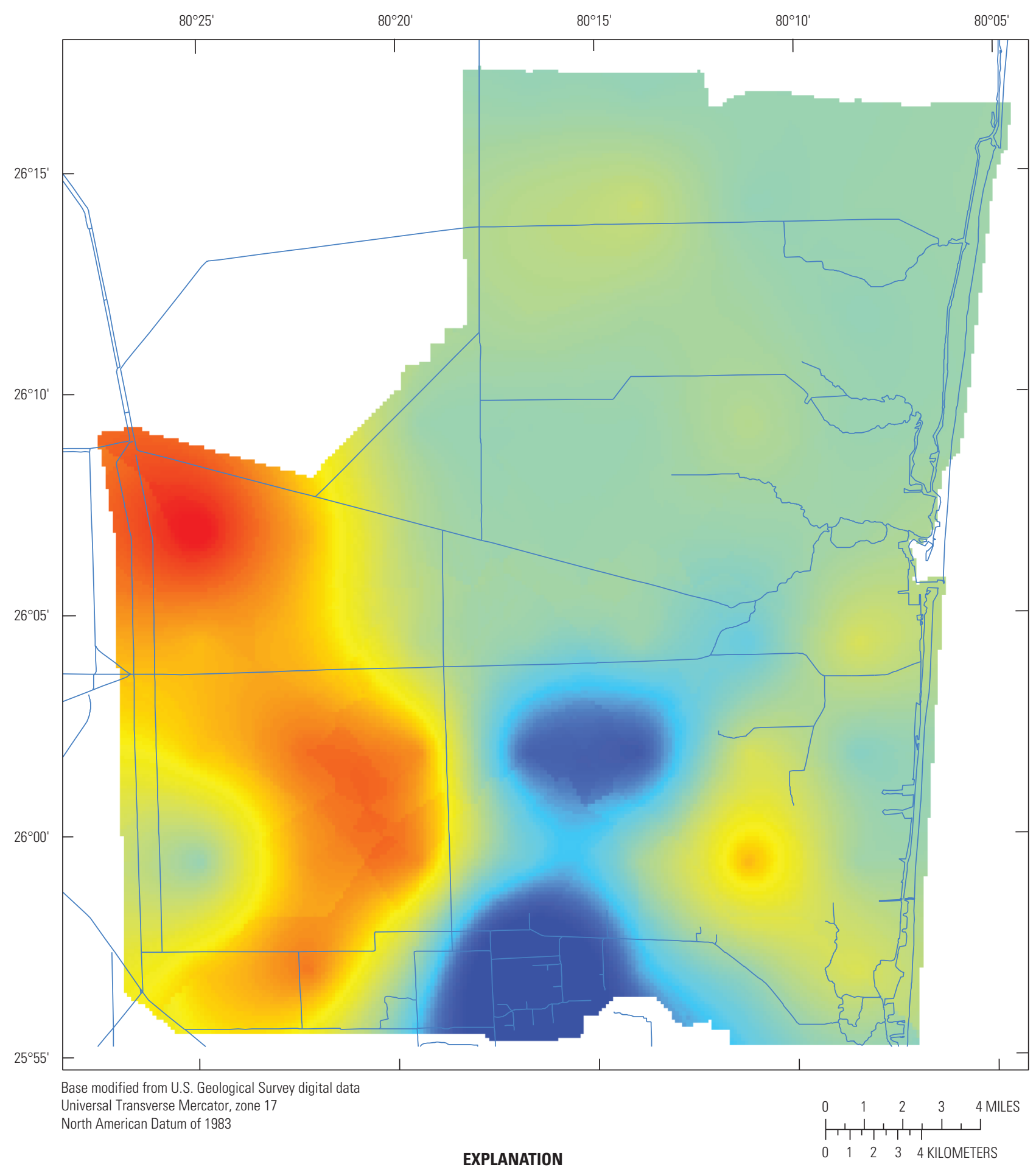

Active model area-Specific storage of layer 2

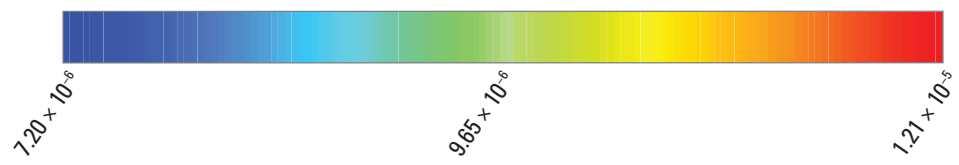

Figure 2.13. Specific storage of layer 2 in the county-scale model. 


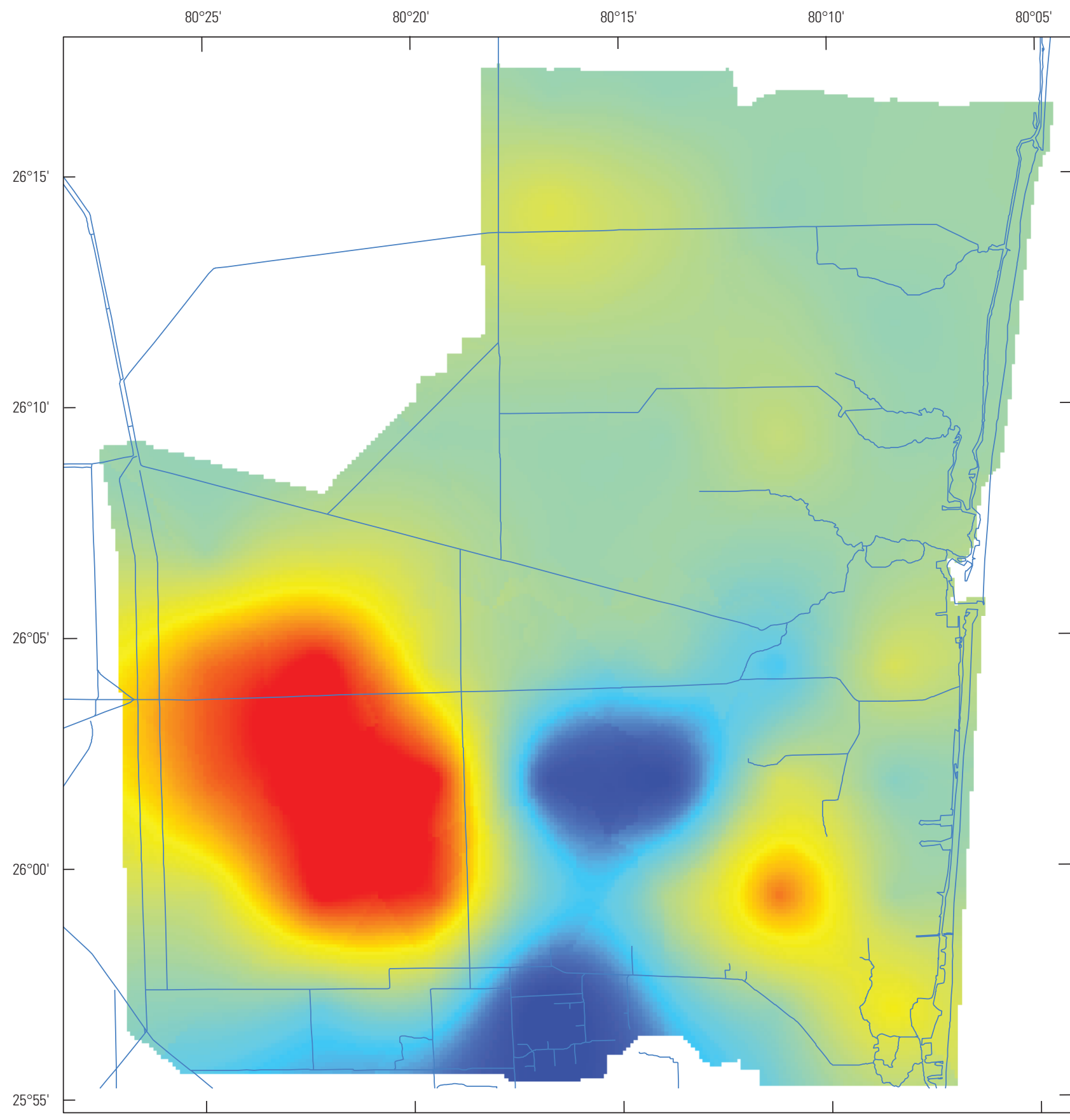

Base modified from U.S. Geological Survey digital data Universal Transverse Mercator, zone 17

North American Datum of 1983

EXPLANATION

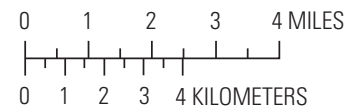

Active model area-Specific storage of layer 3

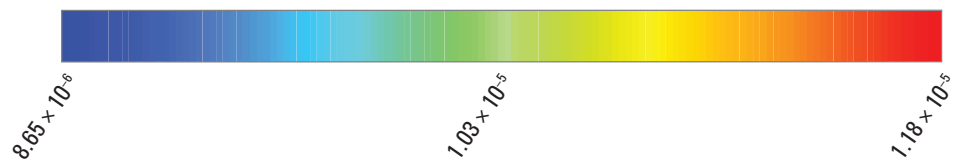

Figure 2.14. Specific storage of layer 3 in the county-scale model. 


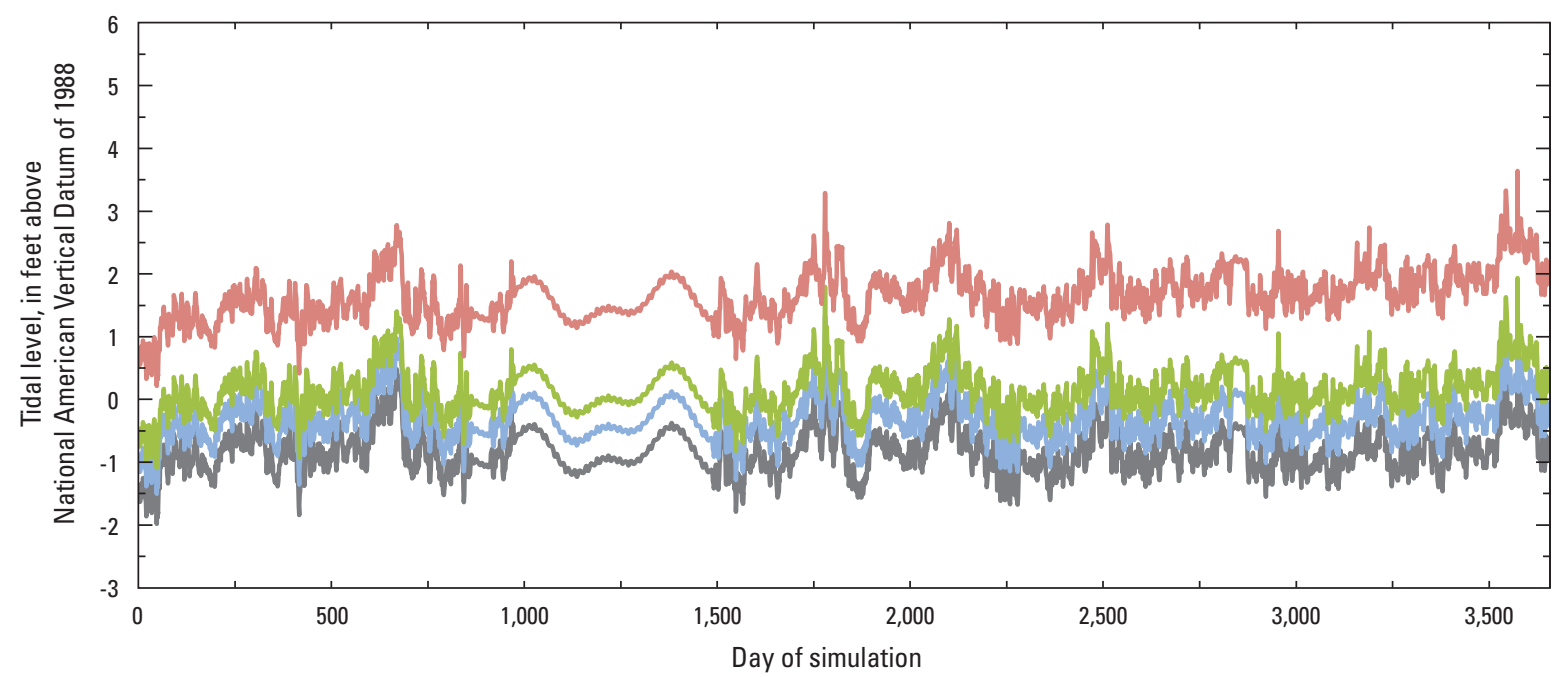

EXPLANATION

- Historical base-case scenario
Current (2017) sea-level rise (SLR) rate_Low SLR
National Research Council SLR projection
$\quad$ Curve I-Intermediate SLR
Curve III-High SLR

Figure 2.15. Historical and future tidal levels used for base-case and sea-level rise scenarios.

\section{Groundwater Pumpage}

Groundwater pumpage within the model was represented by using the MODFLOW 2005 Well package (WEL). The locations and pumping rates were taken from the saltwater-intrusion model (Hughes and others, 2016). Pumping rates for layers 1 and 2 in the 12-layer saltwater-intrusion model were assigned to layer 1 of the county-scale model. Pumping rates for layers 3-10 in the 12-layer saltwater-intrusion model were assigned to layer 2 of the county-scale model. Any pumping rates for layers 11 and 12 in the 12-layer saltwater-intrusion model were assigned to layer 3 of the county-scale model. The pumping rates from the historical period within the saltwater-intrusion model were used for all future scenarios and varied between 160.9 million gallons per day (Mgal/d) and $260.7 \mathrm{Mgal} / \mathrm{d}$, with an average value of $199.5 \mathrm{Mgal} / \mathrm{d}$ (fig. 5 in main body of report).

\section{Initial Conditions}

Initial conditions for the county-scale model were based on results from the saltwater-intrusion model. The average groundwater elevations for January 1, 1990, within the 12 layers were assigned to the 3 groundwater layers within each groundwater cell. The specified canal stages for January 1, 1990, used in the saltwater-intrusion model were used as the initial canal elevations for the county-scale model. Initial flow rates, gate openings, and discharge rates of SWR1 structures were assumed to be zero.

\section{Canal Representation Using the Surface-Water Routing Process}

The extensive canal network throughout Broward County was represented by using the SWR 1 process. Primary and most secondary drainage features were included with locations and parameters taken from the saltwater-intrusion model (Hughes and others, 2016), which was based on the MikeSHE/Mike11 model developed for Broward County (Islam and Dunn, 2006). The central part of the county-scale model's canal network, which encompasses the local-scale model, was dynamically simulated by using active level-pool reach groups connected through weirs, stage-discharge curves, and gate operations (fig. 2.16 and fig. 2 in main body of report). The northern and southern parts of the county's canal network were represented as specified stage reaches, with stage values taken from the saltwater-intrusion model.

The central active canal network includes representation of 19 water-control structures using SWR1 weir structure types, 9 water-control structures using stage-discharge relationships, 3 gated spillway SWR1 structure types, and 1 structure represented as a specified inflow (fig. 2.16, tables 2.1 and 2.2). Weir invert elevations and stage-discharge curves, representing pumps, were based on the MikeSHE/Mike11 model parameters and the South Florida Water Management District (SFWMD) structures handbook (SFWMD, 2016). The gate opening and closing rules for the gated spillway structures were also taken from the SFWMD structures handbook. Discharge through stage-discharge structures begin at various upstream stages 


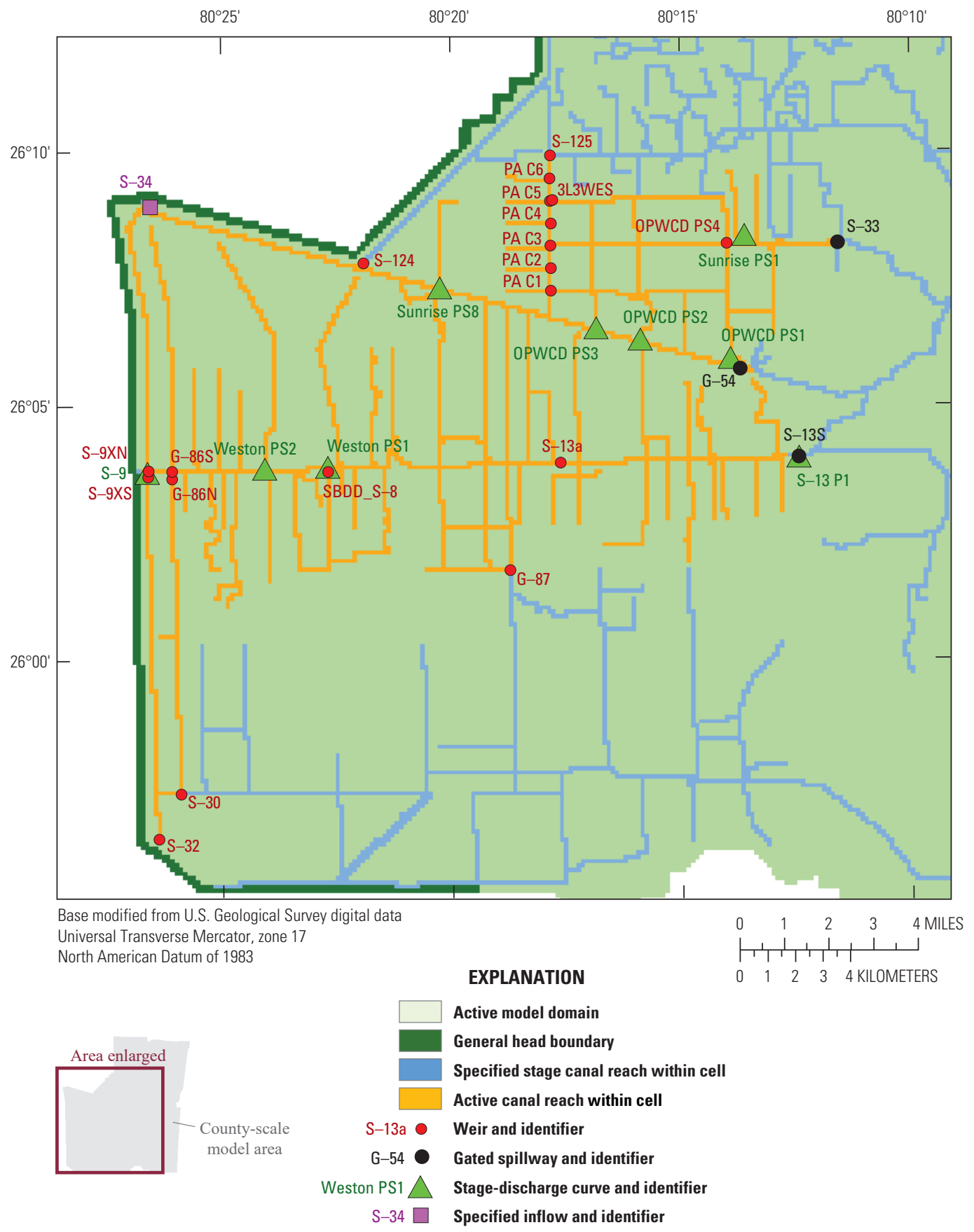

Figure 2.16. Representation of water-control structures in the county-scale model by using the Surface-Water Routing (SWR1) process. 
Table 2.1. Structures represented in the active part of the canal network by using a weir or specified inflow within the surface-water routing (SWR1) process.

[ft, foot; NAVD 88, North American Vertical Datum of 1988; ${ }^{\circ}$, degree; $\mathrm{ft}^{3} / \mathrm{s}$, cubic foot per second]

\begin{tabular}{|c|c|c|c|}
\hline \multicolumn{4}{|c|}{ Represented using weir structure type } \\
\hline Designation & Latitude & Longitude & $\begin{array}{c}\text { Invert } \\
\text { elevation } \\
\text { (ft above } \\
\text { NAVD 88) }\end{array}$ \\
\hline S-125 & $26.1643^{\circ}$ & $-80.2980^{\circ}$ & 4.501 \\
\hline PA C6 & $26.1568^{\circ}$ & $-80.2982^{\circ}$ & 3.002 \\
\hline 3L3WES & $26.1498^{\circ}$ & $-80.2972^{\circ}$ & 1.000 \\
\hline PA C5 & $26.1495^{\circ}$ & $-80.2980^{\circ}$ & 3.002 \\
\hline PA C4 & $26.1422^{\circ}$ & $-80.2978^{\circ}$ & 3.002 \\
\hline OPWCD PS4 & $26.1355^{\circ}$ & $-80.2345^{\circ}$ & 2.000 \\
\hline PA C3 & $26.1349^{\circ}$ & $-80.2979^{\circ}$ & 3.002 \\
\hline S-124 & $26.1294^{\circ}$ & $-80.3653^{\circ}$ & 6.201 \\
\hline PA C2 & $26.1276^{\circ}$ & $-80.2979^{\circ}$ & 3.002 \\
\hline PA C1 & $26.1203^{\circ}$ & $-80.2979^{\circ}$ & 3.002 \\
\hline S-13a & $26.0645^{\circ}$ & $-80.2815^{\circ}$ & 3.000 \\
\hline S-9XN & $26.0621^{\circ}$ & $-80.4431^{\circ}$ & 7.500 \\
\hline $\mathrm{G}-86 \mathrm{~N}$ & $26.0619^{\circ}$ & $-80.4347^{\circ}$ & 3.999 \\
\hline SBDD S-8 & $26.0617^{\circ}$ & $-80.3785^{\circ}$ & 4.199 \\
\hline S-9XS & $26.0601^{\circ}$ & $-80.4432^{\circ}$ & 5.500 \\
\hline G86S & $26.0594^{\circ}$ & $-80.4346^{\circ}$ & 3.999 \\
\hline $\mathrm{G}-87$ & $26.0295^{\circ}$ & $-80.3130^{\circ}$ & 8.000 \\
\hline S-30 & $25.9568^{\circ}$ & $-80.4317^{\circ}$ & 4.500 \\
\hline $\mathrm{S}-32$ & $25.9422^{\circ}$ & $-80.4397^{\circ}$ & 4.500 \\
\hline \multicolumn{4}{|c|}{ Represented using specified inflow } \\
\hline Designation & Latitude & Longitude & $\begin{array}{l}\text { Average flow } \\
\text { into model } \\
\left(\mathrm{ft}^{3} / \mathrm{s}\right)\end{array}$ \\
\hline $\mathrm{S}-34$ & $26.1496^{\circ}$ & $-80.4423^{\circ}$ & 180.3 \\
\hline
\end{tabular}

(table 2.2) and discharge linearly, increasing to the maximum discharge rate at $1.0 \mathrm{ft}$ above the start elevation for all stage-discharge structures except S-9. The maximum rate of discharge of 1,000 cubic feet per second $\left(\mathrm{ft}^{3} / \mathrm{s}\right)$ for $\mathrm{S}-9$ occurs at an upstream stage $0.5 \mathrm{ft}$ above the discharge start elevation of $1.5 \mathrm{ft}$ above NAVD 88. Measured daily average inflows through S-34 taken from the historical period were used as specified inflows to represent S-34 within the model because of unclear or inconsistent operating rules during the simulation period. The average measured flow rate during the historical period (January 1, 1990, to December 30, 1999) was $180.3 \mathrm{ft}^{3} / \mathrm{s}$, with a maximum value of $822.6 \mathrm{ft}^{3} / \mathrm{s}$ (fig. 2.17).
Table 2.2. Structures represented in the active part of the canal network by using a gated spillway or stage-discharge curve within the surface-water routing (SWR1) process.

[ft, foot; NAVD 88, North American Vertical Datum of 1988; ${ }^{\circ}$, degree; $\mathrm{ft}^{3} / \mathrm{s}$, cubic foot per second]

\begin{tabular}{|c|c|c|c|c|}
\hline \multirow[b]{2}{*}{ Designation } & \multicolumn{4}{|c|}{ Represented using gated spillway } \\
\hline & Latitude & Longitude & $\begin{array}{l}\text { Gate open } \\
\text { elevation } \\
\text { (ft above } \\
\text { NAVD 88) }\end{array}$ & $\begin{array}{c}\text { Gate close } \\
\text { elevation } \\
\text { (ft above } \\
\text { NAVD 88) }\end{array}$ \\
\hline S-33 & $26.1357^{\circ}$ & $-80.1945^{\circ}$ & 2.422 & 1.422 \\
\hline $\mathrm{G}-54$ & $26.0948^{\circ}$ & $-80.2298^{\circ}$ & 2.899 & 1.899 \\
\hline S-13 Spillway & $26.0661^{\circ}$ & $-80.2089^{\circ}$ & 0.199 & -0.011 \\
\hline \multirow[b]{2}{*}{ Designation } & \multicolumn{4}{|c|}{ Represented using stage-discharge curve } \\
\hline & Latitude & Longitude & $\begin{array}{c}\text { Discharge } \\
\text { start } \\
\text { elevation }{ }^{1} \\
\text { (ft above } \\
\text { NAVD 88) }\end{array}$ & $\begin{array}{c}\text { Maximum } \\
\text { discharge } \\
\text { rate } \\
\left(\mathbf{f t}^{3} / \mathbf{s}\right)\end{array}$ \\
\hline Sunrise PS1 & $26.1383^{\circ}$ & $-80.2282^{\circ}$ & 3.999 & 98 \\
\hline Sunrise PS8 & $26.1214^{\circ}$ & $-80.3380^{\circ}$ & 3.999 & 98 \\
\hline OPWCD PS3 & $26.1082^{\circ}$ & $-80.2817^{\circ}$ & 2.650 & 300 \\
\hline OPWCD PS2 & $26.1043^{\circ}$ & $-80.2658^{\circ}$ & 2.650 & 300 \\
\hline OPWCD PS1 & $26.0984^{\circ}$ & $-80.2334^{\circ}$ & 2.650 & 400 \\
\hline S-13 Pump & $26.0661^{\circ}$ & $-80.2089^{\circ}$ & 0.700 & 540 \\
\hline Weston PS1 & $26.0633^{\circ}$ & $-80.3786^{\circ}$ & 3.000 & 180 \\
\hline Weston PS2 & $26.0627^{\circ}$ & $-80.4013^{\circ}$ & 3.000 & 360 \\
\hline S-9 & $26.0615^{\circ}$ & $-80.4435^{\circ}$ & 1.500 & 1,000 \\
\hline
\end{tabular}

${ }^{1}$ Maximum discharge occurs at $1 \mathrm{ft}$ above discharge start elevation for all stage-discharge structures except S-9 which occurs $0.5 \mathrm{ft}$ above discharge start elevation.

\section{Representation of Additional Drainage Features}

Within the saltwater-intrusion model, the tertiary drainage features were represented by using the MODFLOW 2005 Drain package (DRN). Drainage elevations within this package were defined by using the watershed-management plans developed for the drainage districts (Hughes and others, 2016). The county-scale model used this approach in representing the detailed drainage features in parts of the northern and southern model area that correspond to specified-head SWR1 canal reaches. Areas where the canal network was modeled by using SWR1 level-pool routing and active structures did not incorporate the DRN package (fig. 2.18). The drainage elevations were defined as those used in the saltwater-intrusion model and varied from $2.1 \mathrm{ft}$ to $16.0 \mathrm{ft}$ above NAVD 88, with the highest elevations used in the northern part of the model area. 


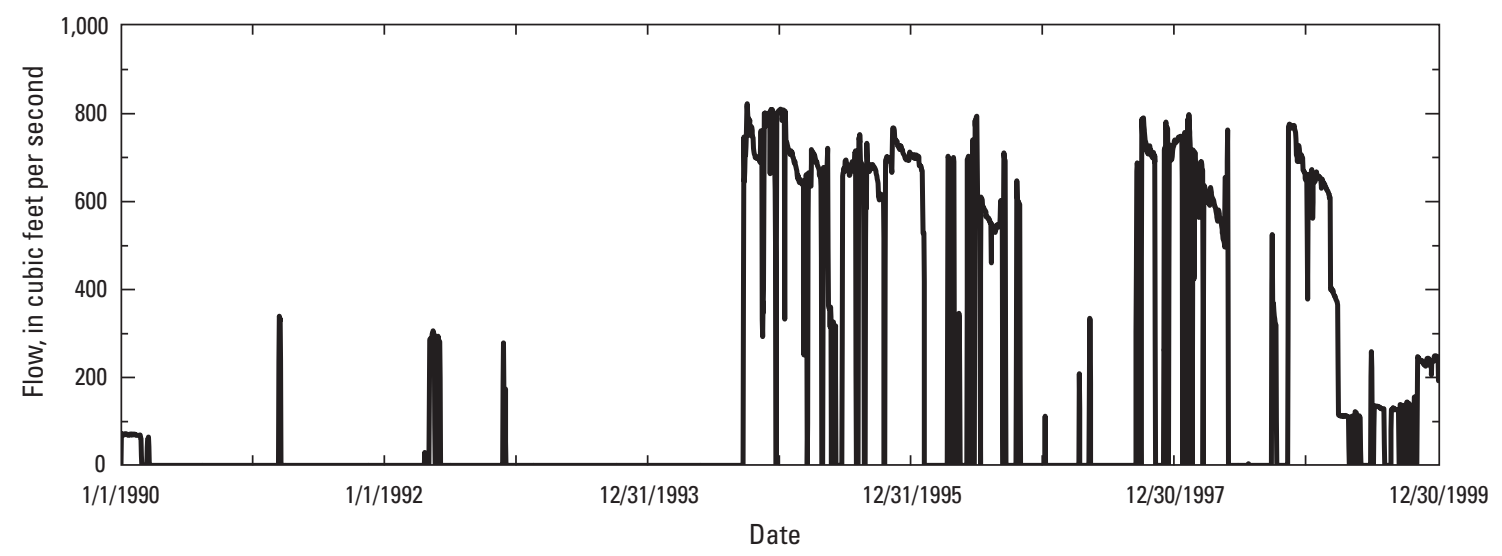

Figure 2.17. Measured flow through structure S-34. Flows greater than 0.0 correspond to flow into the Surface-Water Routing (SWR1) canal network.

\section{Representation of Additional Hydrologic Processes Using the Urban Runoff Process}

The remaining hydrologic processes within the county-scale model were represented by using the newly developed Urban Runoff (URO) process. These hydrologic processes include precipitation, evapotranspiration, infiltration, and recharge (fig. 2.19). The URO process represents unsaturated zone and surface-water storage for each cell; overland flow; rainfall; evaporation from the surface water and the unsaturated and saturated zones; infiltration from the surface-water storage into the unsaturated zone; recharge from the unsaturated zone into the MODFLOW groundwater cell; and when necessary, groundwater discharge from the MODFLOW groundwater cell into the surface-water storage (Decker and Hughes, 2013). The county- and local-scale models were initially setup to simulate overland flow; however, the predominantly low surface-water depths throughout the urban areas did not necessitate its inclusion into the final setup, which helped to reduce model runtimes. The values for the frictional coefficients and detention depths developed for the model are included in this section despite not being used in producing the final results.

\section{Precipitation and Evapotranspiration}

For each time step within the URO process, the precipitation and evapotranspiration (ET) volumes are calculated by multiplying the specified rate by the time-step length. First, precipitation is added to the surface-water storage. Evaporation is then removed from the surface-water storage first at the full potential rate; if the potential rate is not satisfied, any remaining volume is then removed from the unsaturated zone storage at a reduced rate, dependent on the water content, and lastly, any remaining volume is removed from the groundwater cell at a linearly reduced rate down to a user-defined extinction depth (Decker and Hughes, 2013).

The precipitation and potential ET values used for model simulations were provided by the Center for
Ocean-Atmospheric Prediction Studies (COAPS). The output for two general circulation models, Community Climate System Model (CCSM) and Hadley Centre Coupled Model version 3 (HadCM3), were used to provide the boundary conditions for a regional climate model that encompasses the southeastern United States. The regional climate model had a 10-kilometer $(\mathrm{km})$ by $10-\mathrm{km}$ grid resolution and simulated a historical period (January 1, 1968, to December 31, 1999) and a future period (January 1, 2038, to December 31, 2069). Precipitation and potential ET outputs were provided as daily values. The precipitation output was bias-corrected by COAPS for the entire climate model simulation period by using the quantile matching approach, which utilizes monthly cumulative distribution functions (Wood and others, 2002). This approach ensures that the bias-corrected regional climate model output for precipitation has the same mean and variance as the observation dataset.

Twenty-two $10-\mathrm{km}$ by $10-\mathrm{km}$ climate cells cover the county-scale model's active domain (fig. 2.20). The rainfall and potential ET input for each cell was specified as the output from the surrounding regional climate model cell, creating 22 rainfall and ET cells. The average rainfall for each month of the year for the CCSM model ranged from 2.2 inches (in.) for February to 9.6 in. for June during the base-case simulation period and from $1.65 \mathrm{in}$. for January to $12.3 \mathrm{in}$. for August during the future simulation period. The average rainfall for each month of the year for the HadCM3 model ranged from 1.7 in. for December to 10.0 in. for June during the base-case simulation period and from 1.66 in. for February to 7.6 in. for October during the future simulation period (fig. 2.21). The CCSM yearly rainfall varied from $40.3 \mathrm{in.}$ to $67.0 \mathrm{in}$., with an average of 56.4 in. during the base-case simulation period. The HadCM3 yearly rainfall varied from 31.9 in. to 73.7 in., with an average of 57.5 in. during the base-case simulation period (fig. $16 A$ in main body of report). The CCSM yearly rainfall varied from $54.0 \mathrm{in.}$ to $77.4 \mathrm{in}$., with an average of $66.3 \mathrm{in}$. during the future simulation period. The HadCM3 yearly rainfall varied from 39.4 in. to $64.7 \mathrm{in}$., with an average of $53.5 \mathrm{in}$. during the future simulation period (fig. $16 \mathrm{~B}$ in main 


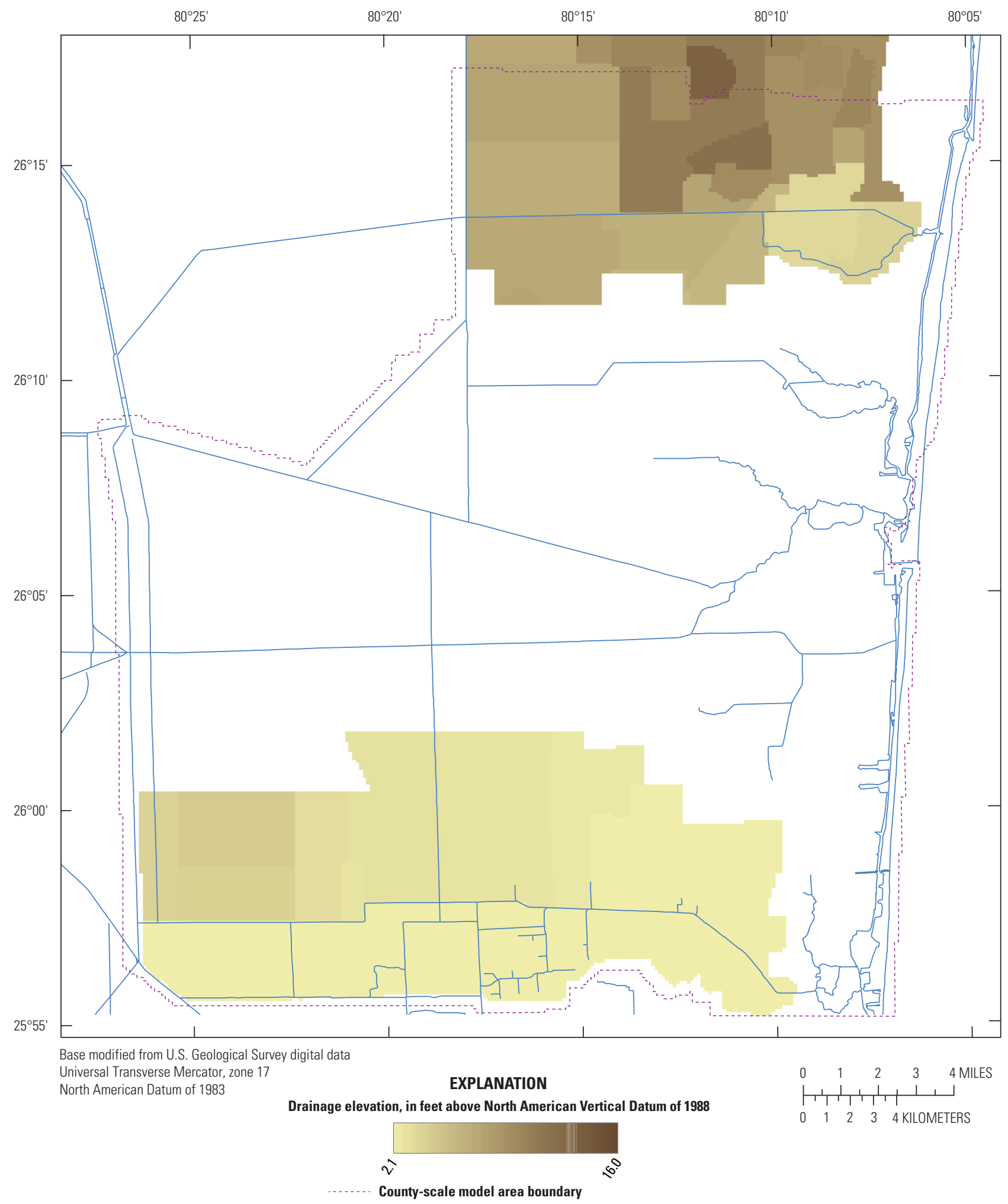

Figure 2.18. Drainage elevations used in county-scale model construction to simulate tertiary and detailed drainage features in areas using specified-head Surface-Water Routing (SWR1) canal reach types. 


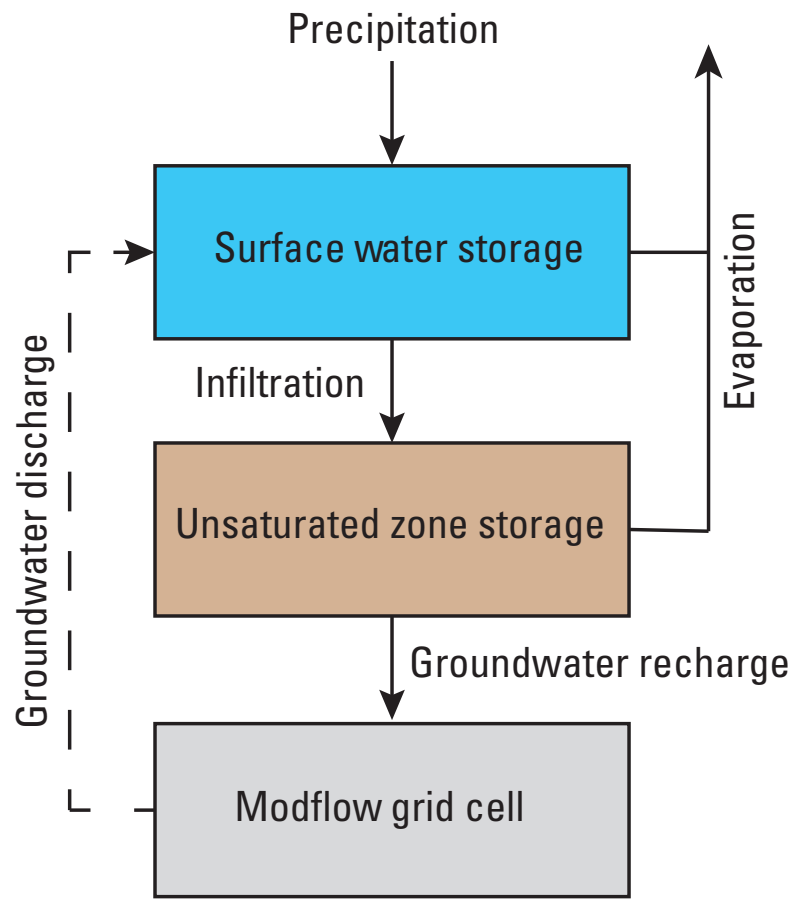

Figure 2.19. Hydrologic processes represented by the Urban Runoff process.

body of report). These average yearly rainfall totals represent a 17.6-percent increase in the CCSM output compared to the base-case simulation period and a 7.0-percent decrease in the HadCM3 output compared to the base-case simulation period. The CCSM future scenarios were therefore referred to as "wetter future," whereas the HadCM3 future scenarios were referred to as "drier future."

The maximum daily rainfall was $3.54 \mathrm{in}$. and $9.95 \mathrm{in}$. for the CCSM base-case and future periods, respectively, when analyzing daily rainfall averaged over the active county-scale model area. The maximum daily rainfall was $3.66 \mathrm{in}$. and 5.43 in. for the HadCM3 base-case and future periods, respectively, when analyzing daily rainfall averaged over the active county-scale model area. The 1-day rainfall totals of 7.5 in., 10.75 in., and 13.0 in. represented 5-year, 25-year, and 100-year precipitation events within the model area. The future scenario CCSM was the only simulation to include a day when the daily rainfall total averaged over the entire active area reached a 5-year precipitation event of $7.5 \mathrm{in}$. (fig. 2.22). The two base-case scenarios included no individual climate cell output locations that reached any of these thresholds either. The CCSM future scenario output included 9 days when the 5 -year event threshold was reached, 2 days when the 25-year threshold was reached, and 1 day when the 100 -year threshold was reached by at least 1 cell within the active county-model area. The HadCM3 future scenario output included 3 days when the 5 -year threshold was reached, 1 day when the 25-year threshold was reached, and zero days when the 100 -year precipitation threshold was reached by at least 1 cell within the active county-model area.
The average annual potential ET totals were $78.2 \mathrm{in.}$ and $85.7 \mathrm{in}$. for the CCSM base-case simulation and future scenario periods, respectively. The average annual potential ET totals were 74.1 in. and 86.4 in. for the HadCM3 base-case simulation and future scenario periods, respectively (fig. 18 in main body of report). The average potential ET for each month of the year for the CCSM model ranged from $4.4 \mathrm{in}$. for December to $8.5 \mathrm{in}$. for July during the base-case simulation period and from $4.67 \mathrm{in}$. for December to $9.3 \mathrm{in}$. for July during the future simulation period. The average potential ET for each month of the year for the HadCM3 model ranged from $4.3 \mathrm{in}$. for December to $7.7 \mathrm{in}$. for July during the base-case simulation period and from 4.4 in. for December to 9.0 in. for July during the future simulation period (fig. 2.23).

\section{Infiltration and Groundwater Recharge}

Within the URO process, infiltration into and recharge out of the conceptualized unsaturated zone represented within the top layer of each groundwater column is controlled by using a linear water-content-dependent relationship:

$$
h_{\text {inf }}=k_{\text {inf } 0}(1-\theta) \Delta t,
$$

$h_{\text {rec }}=k_{\text {rec } 0} \theta \Delta t$,

$$
\theta=\frac{L_{U Z S}}{L_{U Z S m x}}
$$

where

$$
\begin{aligned}
h_{\text {inf }} & \text { is the infiltration depth }(\mathrm{L}) ; \\
k_{\text {inf0 }} & \text { is the maximum infiltration rate }(\mathrm{L} / \mathrm{T}) ; \\
\theta & \text { is the water content; } \\
\Delta t & \text { is the URO time step (T); } \\
h_{\text {rec }} & \text { is the recharge depth }(\mathrm{L}) ; \\
k_{\text {rec0 }} & \text { is the maximum recharge rate }(\mathrm{L} / \mathrm{T}) ; \\
L_{U Z S} & \text { is the current unsaturated zone storage within } \\
& \text { the cell (L); and } \\
L_{U Z S m x} & \text { is the maximum storage depth of the } \\
& \text { unsaturated zone }(\mathrm{L}) .
\end{aligned}
$$

The values of $k_{\text {info }}$ used in the model were calculated by using a combination of land-use coverage, soil classification coverage, and typical dry soil infiltration rates. The values of $k_{\text {rec } 0}$ used in model were calculated on the basis of the soil classification coverage and typical saturated soil hydraulic conductivities $\left(k_{\mathrm{ss}}\right)$. The land-use coverage was generated by the SFWMD from 2008-9 aerial photographs (fig. 2.24). The coverage within the county-scale model area was simplified to include 17 types of land use, and the impervious area (IA) for each type was estimated by using published data (table 2.3) (USDA, 1986; Kluitenberg, 1994; Cappiella and Brown, 2001; Dougherty and others, 2004). 


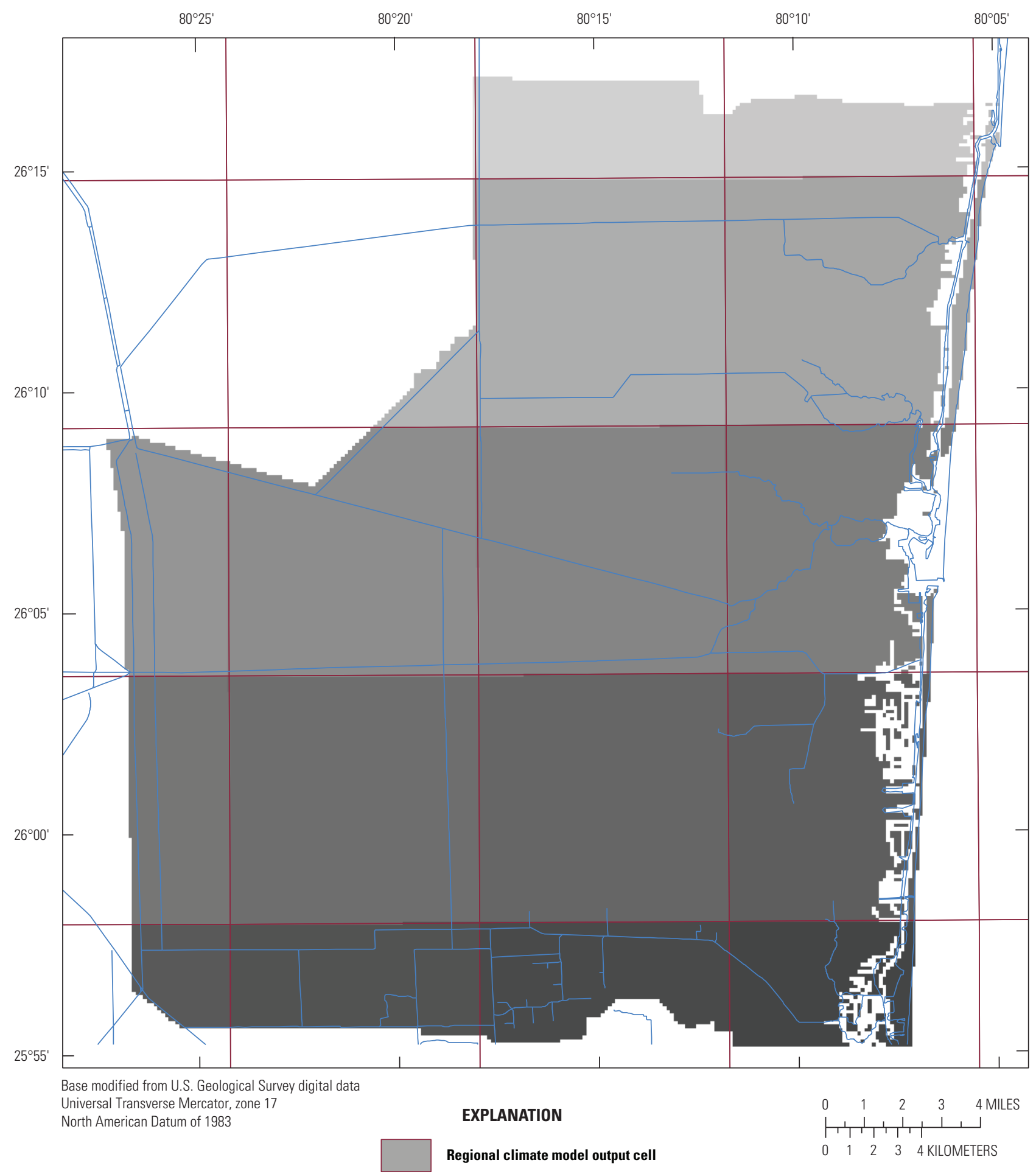

Figure 2.20. Regional climate model output cells coverage of the county-scale model. 


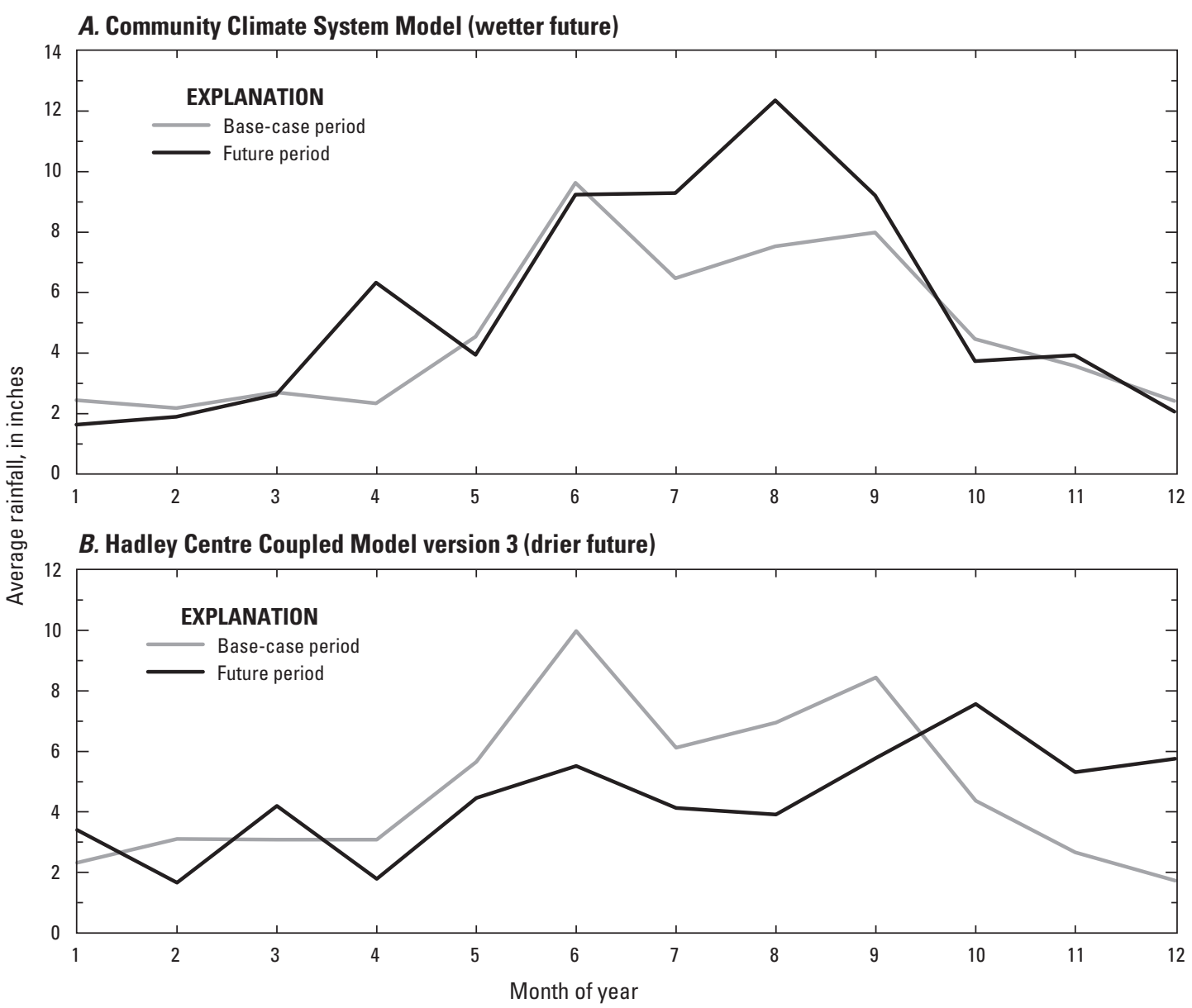

Figure 2.21. Regional climate model average precipitation by month during base-case and future simulation periods for $A$, the Community Climate System Model (CCSM) wetter future, and $B$, the Hadley Centre Coupled Model version 3 (HadCM3) drier future scenarios.

A soil classification coverage derived from the SFWMD Natural Soils Landscape Position (NSLP) database was generated by the SFWMD and used to calculate $k_{\text {info }}$ and $k_{\text {rec } 0}$ (fig. 2.25) (Zahina and others, 2001). On the basis of the NSLP description, each category within the soil classification coverage was assigned a corresponding hydrologic group code and soil drainage class code. Typical dry soil infiltration rates and saturated hydraulic conductivity for the corresponding soil descriptions were estimated for each hydrologic group code (tables 2.4 and 2.5) (Akan, 1993).

From the data coverages, the area of each land-use category and soil type within each URO model cell was calculated. The $k_{\text {info }}$ for each cell was calculated by multiplying the area-weighted arithmetic mean of the impervious area by the area-weighted harmonic mean of the dry soil infiltration rate:

$$
k_{\mathrm{inf} 0}=\frac{\sum_{j=1}^{m} a l_{j} I A_{j}}{\sum_{j=1}^{m} a l_{j}}\left(\frac{\sum_{i=1}^{n} a s_{i}}{\sum_{i=1}^{n} \frac{a s_{i}}{k_{d s i}}}\right),
$$

where

$a l_{j} \quad$ is the area within the cell-designated land-use category $j\left(\mathrm{~L}^{2}\right)$;

$I A_{j} \quad$ is the estimated impervious area for land-use category $j$;

$a s_{i} \quad$ is the area within the cell-designated soil classification $i\left(\mathrm{~L}^{2}\right)$; and

$k_{d s i} \quad$ is the dry soil infiltration rate for soil classification $i(\mathrm{~L} / \mathrm{T})$.

The resulting values of $k_{\text {inf }}$ within the county-scale model varied from $0.4 \mathrm{ft} / \mathrm{d}$ to $10 \mathrm{ft} / \mathrm{d}$, with a mean of $3.94 \mathrm{ft} / \mathrm{d}$ (fig. 2.26). The $k_{\text {rec }}$ for each cell was calculated by finding the area-weighted harmonic mean of the saturated soil hydraulic conductivity:

$$
k_{\text {rec0 }}=\frac{\sum_{i=1}^{n} a s_{i}}{\sum_{i=1}^{n} \frac{a s_{i}}{k_{s s i}}},
$$

where

$k_{s s i} \quad$ is the saturated soil hydraulic conductivity for soil classification $i(\mathrm{~L} / \mathrm{T})$. 
A. Community Climate System Model (CCSM) base-case period

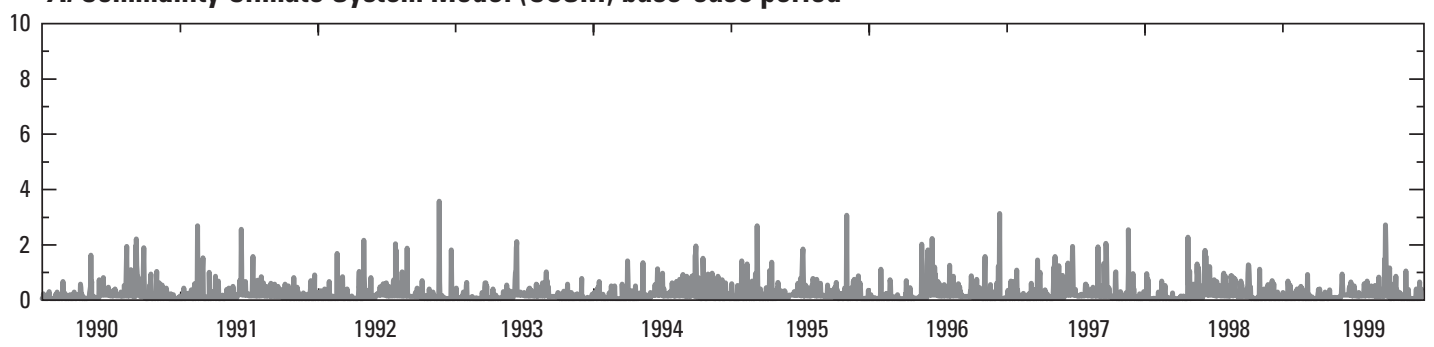

B. Hadley Centre Coupled Model version 3 (HadCM3) base-case period

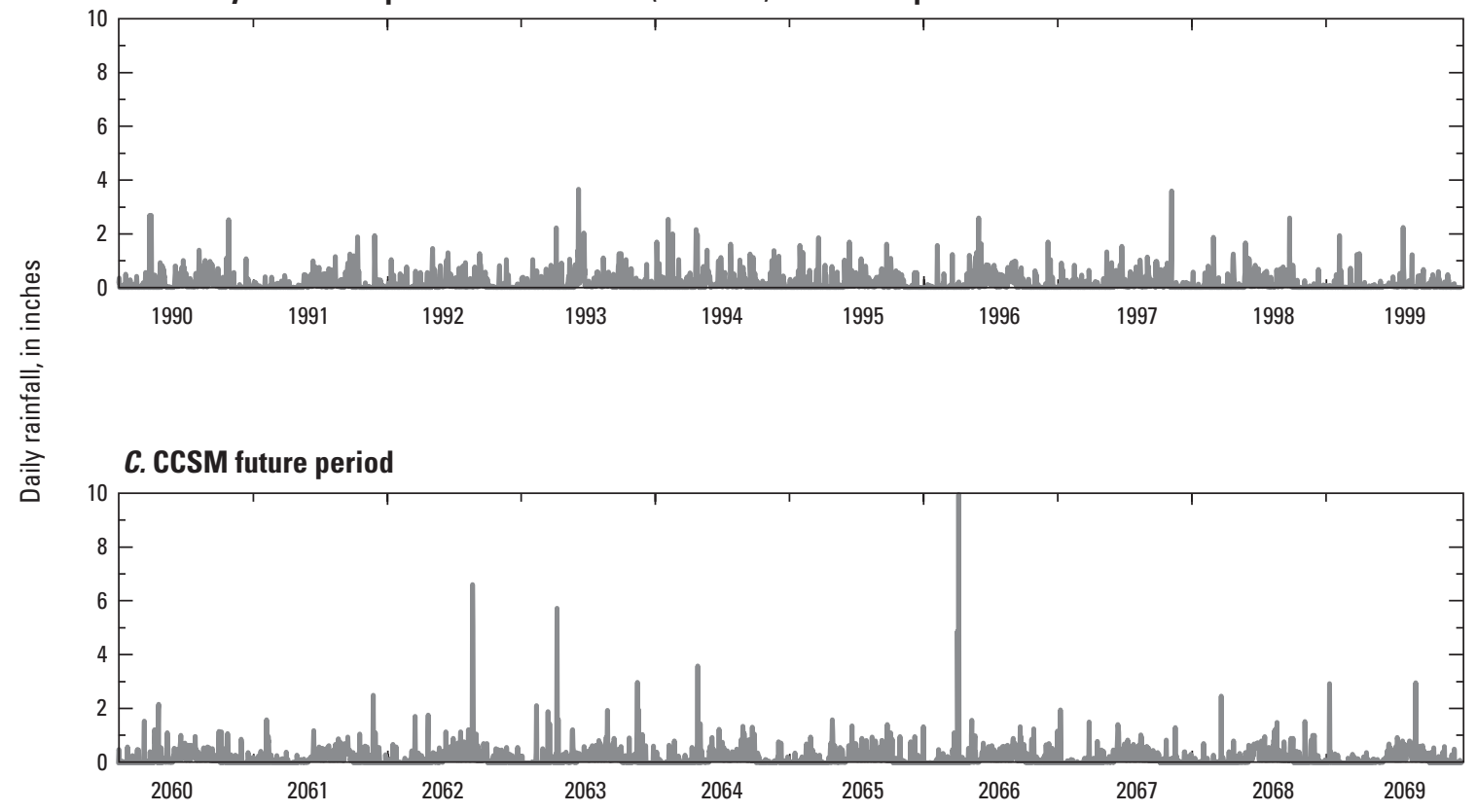

D. HadCM3 future period

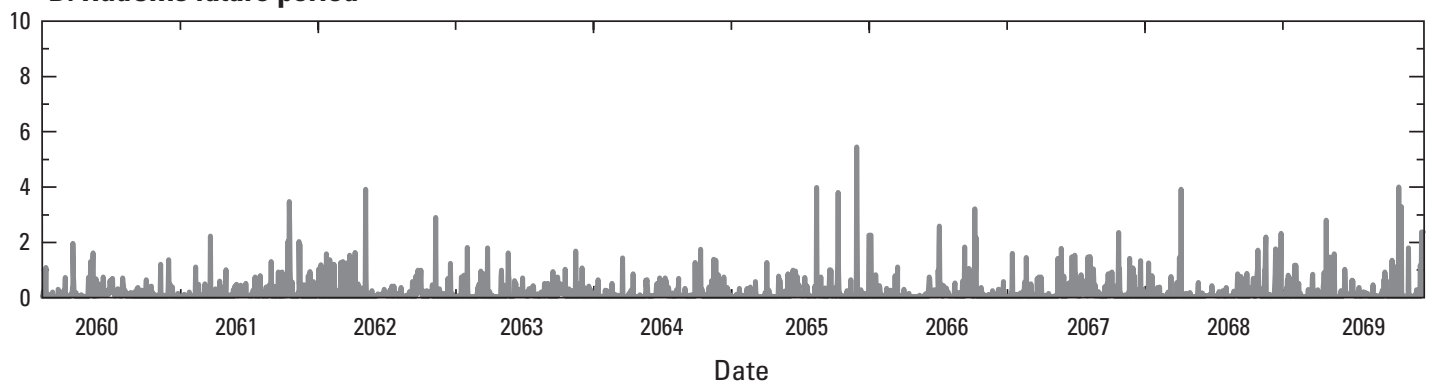

Figure 2.22. Regional climate model daily rainfall averaged over active county-model area during basecase and future simulation periods for $A, C$, the Community Climate System Model (CCSM) wetter future, and $B, D$, the Hadley Centre Coupled Model version 3 (HadCM3) drier future scenarios. 


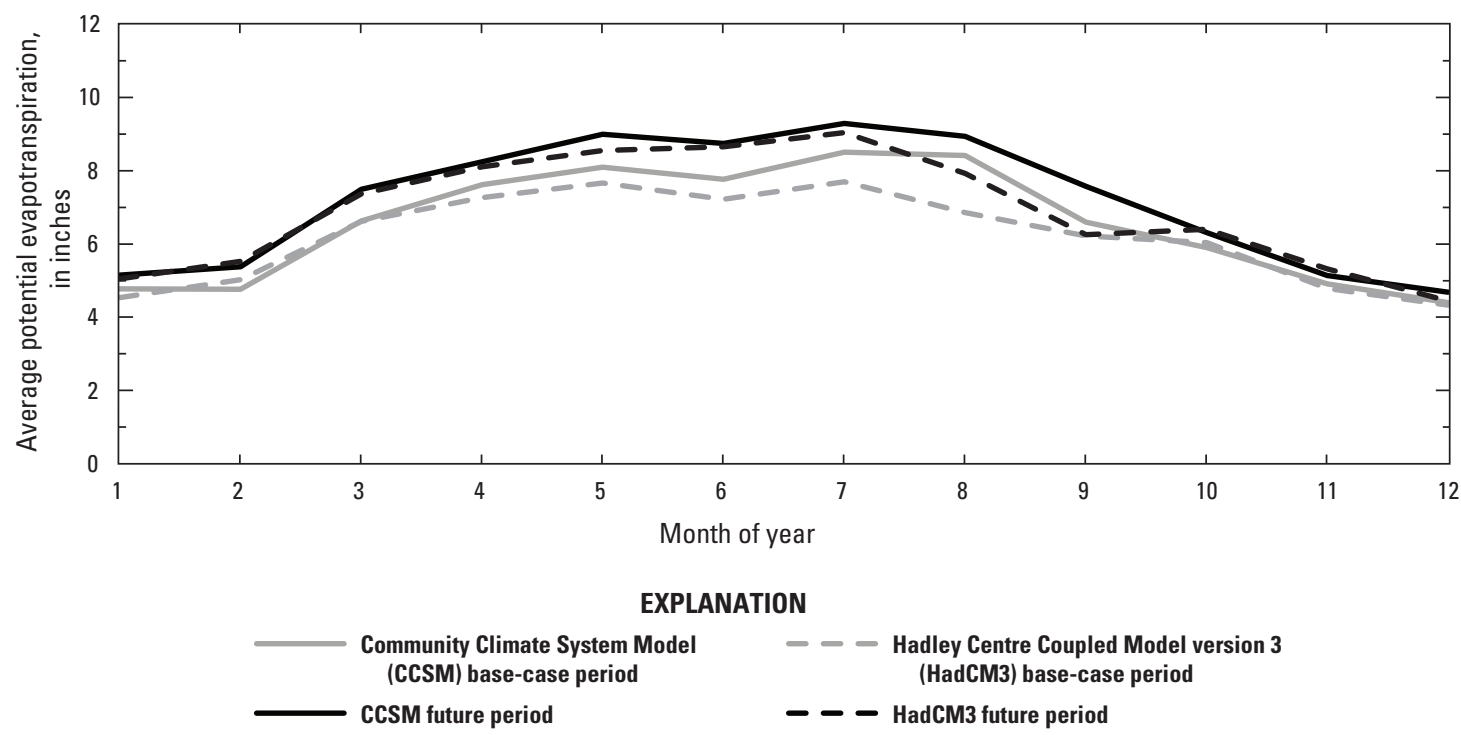

Figure 2.23. Regional climate model average potential evapotranspiration by month during basecase and future simulation periods for the Community Climate System Model (CCSM) wetter future and Hadley Centre Coupled Model version 3 (HadCM3) drier future scenarios.

This method resulted in values of $k_{\text {rec } 0}$ within the county-scale model that varied from $0.14 \mathrm{ft} / \mathrm{d}$ to $10 \mathrm{ft} / \mathrm{d}$. The lower values of $k_{\text {rec } 0}$ within the urban areas of the county-scale model did not adequately transfer water from the unsaturated zone to the underlying MODFLOW cell during early testing, and a minimum $k_{\text {rec } 0}$ of $1.00 \mathrm{ft} / \mathrm{d}$ was specified for all simulations described in this report (fig. 2.27). The resulting mean value of $k_{\text {rec0 }}$ was $3.79 \mathrm{ft} / \mathrm{d}$.

\section{Overland Flow}

The URO process has the ability to simulate two-dimensional overland flow by using the Manning's equation. After initial testing, it was determined that the low ponding depths within the urban area did not necessitate the inclusion of this option. The required coefficients were calculated and included in this section but were not used. The Manning's $n$ values used for the model were calculated on the basis of the land-use coverage (fig. 2.24) and Manning's $n$ values used by the SFWMD in previous studies for similar land-use types (tables 2.6 and 2.7) (SFWMD, 2005). The composite Manning's $n$ value for each cell was calculated as the area-weighted arithmetic mean of the Manning's $n$ of all the land-use types within a cell:

$$
n=\frac{\sum_{i=1}^{n} a l_{i} n_{i}}{\sum_{i=1}^{n} a l_{i}},
$$

where

$a l_{i} \quad$ is the area within the cell-designated land-use category $i\left(\mathrm{~L}^{2}\right)$; and

$n_{i} \quad$ is the estimated Manning's $n$ for the land-use category $i\left(\mathrm{~T} / \mathrm{L}^{1 / 3}\right)$.
Detention depth values for these same land-use types were used to calculate an area-weighted arithmetic mean similar to equation 12 in the main body of this report. No overland flow occurs below this value. The resultant composite Manning's $n$ values and detention depth values are shown in figures 2.28 and 2.29 .

\section{Local-Scale Numerical Model Construction}

The local-scale model relied heavily on the variable-density model developed for central and southern Broward County (saltwater-intrusion model; Hughes and others, 2016) for the hydraulic parameters and layering. The precipitation, ET, maximum infiltration rate, and maximum recharge rates were calculated by using the same methodology used to calculate those same parameters in the county-scale model.

\section{Extent and Discretization}

The local-scale model's extent was designed to include areas of interest within southern and central Broward County (figs. 2 and 3 in main body of report). The spatial resolution was increased with horizontal cell dimensions of $166.7 \mathrm{ft}$ by $166.7 \mathrm{ft}$, resulting in three columns and rows within each county-scale model row and column. The same layering scheme used in the county-scale model was used in the local-scale model. The calibrated parameters used for the 12-layer saltwater-intrusion model also were used to construct three layers using the upper, production, and lower layer designations. The local-scale model has 531 columns and 159 rows, with 63,445 active cells per model layer covering $63.24 \mathrm{mi}^{2}$. 


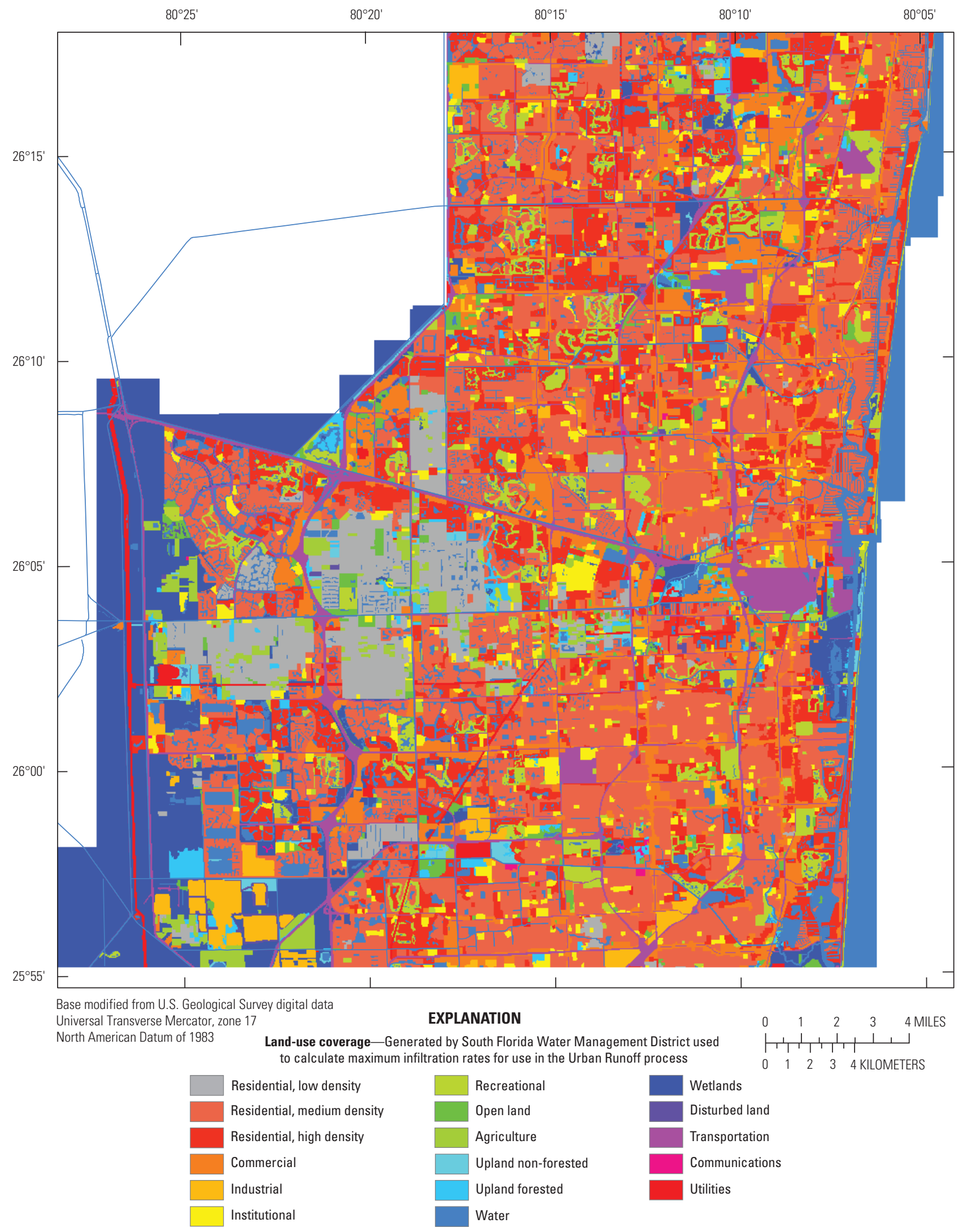

Figure 2.24. Land-use coverage generated by the South Florida Water Management District and used to calculate maximum infiltration rates for use in the Urban Runoff process. 
Table 2.3. Published estimated percentage of impervious area for land-use categories found in Broward County, Florida.

[USDA, U.S. Department of Agriculture; IA, impervious area; \%, percent]

\begin{tabular}{|c|c|c|c|c|c|}
\hline Land-use category & $\begin{array}{c}\text { Dougherty and } \\
\text { others (2004) }\end{array}$ & $\begin{array}{l}\text { Cappiella and } \\
\text { Brown (2001) }\end{array}$ & $\begin{array}{c}\text { Kluitenberg, } \\
\text { (1994) }\end{array}$ & USDA (1986) & IA value used \\
\hline Low-density residential & $5-10 \%$ & $11-14 \%$ & $19 \%$ & $12-20 \%$ & $14 \%$ \\
\hline High-density residential & $35-45 \%$ & $33 \%$ & $51 \%$ & $65 \%$ & $47 \%$ \\
\hline Commercial & $35-55 \%$ & $72 \%$ & $56 \%$ & $85 \%$ & $64 \%$ \\
\hline Recreational & \multirow{4}{*}{$\begin{array}{c}2-7 \% \\
\text { (Agriculture, } \\
\text { forest, golf, idle } \\
\text { land) }\end{array}$} & $\begin{array}{c}5-12 \% \\
\text { (Parks, golf) }\end{array}$ & No value given & No value given & $7 \%$ \\
\hline Open land (urban) & & $9 \%$ & $11 \%$ & No value given & $8 \%$ \\
\hline $\begin{array}{l}\text { Cropland/pasture, tree crops, nurseries, } \\
\text { farms }\end{array}$ & & $\begin{array}{c}2 \% \\
\text { (Agriculture) }\end{array}$ & $\begin{array}{c}2 \% \\
\text { (Agriculture) }\end{array}$ & No value given & $3 \%$ \\
\hline Upland nonforested & & No value given & No value given & No value given & $2 \%$ \\
\hline Water & No value given & No value given & \multirow{2}{*}{$\begin{array}{c}51 \% \\
\text { (Water, wetlands) }\end{array}$} & No value given & $0 \%$ \\
\hline Wetland & No value given & No value given & & No value given & $2 \%$ \\
\hline Disturbed land & $50-70 \%$ & No value given & No value given & No value given & $60 \%$ \\
\hline Transportation & $50-70 \%$ & No value given & $53 \%$ & No value given & $57 \%$ \\
\hline Communications/utilities & No value given & No value given & No value given & No value given & $62 \%$ \\
\hline
\end{tabular}

The simulation periods and MODFLOW stress periods and time steps used in the local-scale model were the same as those used in the county-scale model. The historical simulation period was January 1, 1990, to December 31, 1999, and the future simulation period was January 1, 2060, to December 31,2069 . The model used a daily MODFLOW stress period and hourly time steps (table 1 in main body of report).

\section{Land Surface and Layer-Bottom Elevations}

The top of layer 1 , which corresponds to land surface, ranged from $-2.2 \mathrm{ft}$ to $114.1 \mathrm{ft}$ above NAVD 88 , with an average of $5.05 \mathrm{ft}$ above NAVD 88 (fig. 2.30). The land-surface elevations were created by using the 2007-8 Florida Division of Emergency Management lidar data prepared by the SFWMD. The tops of layer 1 were calculated as the mean of the $10-\mathrm{ft}$ resolution lidar values within each grid cell. The layer bottoms were calculated through the bilinear interpolation of the corresponding bottoms of the county-scale model. The elevations of the bottom of layer 1 varied between $-71.8 \mathrm{ft}$ and $-36.40 \mathrm{ft}$ above NAVD 88 , with an average elevation of $-54.13 \mathrm{ft}$ above NAVD 88 (fig. 2.31A). The elevations of the bottom of layer 2 varied between $-133.6 \mathrm{ft}$ and $-67.5 \mathrm{ft}$ above NAVD 88, with an average elevation of $-108.73 \mathrm{ft}$ above NAVD 88 (fig. $2.31 B$ ). The elevations of the bottom of layer 3 varied between -220.2 and -148.6 ft above NAVD 88, with an average elevation of -189.32 ft above NAVD 88 (fig. 2.31C).

\section{Hydraulic Parameters}

The hydraulic parameters used for the local-scale model were calculated by using the parameters calculated for the county-scale model (figs. 2.5 to 2.14), which were derived from the calibrated parameters used in the saltwater-intrusion model (Hughes and others, 2016). The values used in the local-scale model were calculated through the bilinear interpolation of the values used in the county-scale model.

\section{Horizontal and Vertical Hydraulic Conductivity}

The calculated values of horizontal hydraulic conductivity for layer 1 of the local-scale model varied from $411.8 \mathrm{ft} / \mathrm{d}$ to $2,439.2 \mathrm{ft} / \mathrm{d}$, with a mean of $862.4 \mathrm{ft} / \mathrm{d}$ (fig. 2.32A). The calculated values of horizontal hydraulic conductivity for layer 2 of the local-scale model varied from $341.8 \mathrm{ft} / \mathrm{d}$ to $25,932.3 \mathrm{ft} / \mathrm{d}$, with a mean of $3,141.9 \mathrm{ft} / \mathrm{d}$ (fig. $2.32 B$ ). The calculated values of horizontal hydraulic conductivity for layer 3 of the local-scale model varied from $241.1 \mathrm{ft} / \mathrm{d}$ to $1,727.6 \mathrm{ft} / \mathrm{d}$, with a mean of $722.1 \mathrm{ft} / \mathrm{d}$ (fig. $2.32 C$ ).

The calculated values of vertical hydraulic conductivity for layer 1 of the local-scale model varied from $4.9 \mathrm{ft} / \mathrm{d}$ to $14.2 \mathrm{ft} / \mathrm{d}$, with a mean of $8.26 \mathrm{ft} / \mathrm{d}$ (fig. $2.33 \mathrm{~A}$ ). The calculated values of vertical hydraulic conductivity for layer 2 of the local-scale model varied from $5.4 \mathrm{ft} / \mathrm{d}$ to $15.8 \mathrm{ft} / \mathrm{d}$, with a mean of $10.6 \mathrm{ft} / \mathrm{d}$ (fig. $2.33 \mathrm{~B}$ ). The calculated values of vertical conductivity for layer 3 of the local-scale model varied from $3.7 \mathrm{ft} / \mathrm{d}$ to $6.1 \mathrm{ft} / \mathrm{d}$, with a mean of $5.00 \mathrm{ft} / \mathrm{d}$ (fig. $2.33 C$ ). 


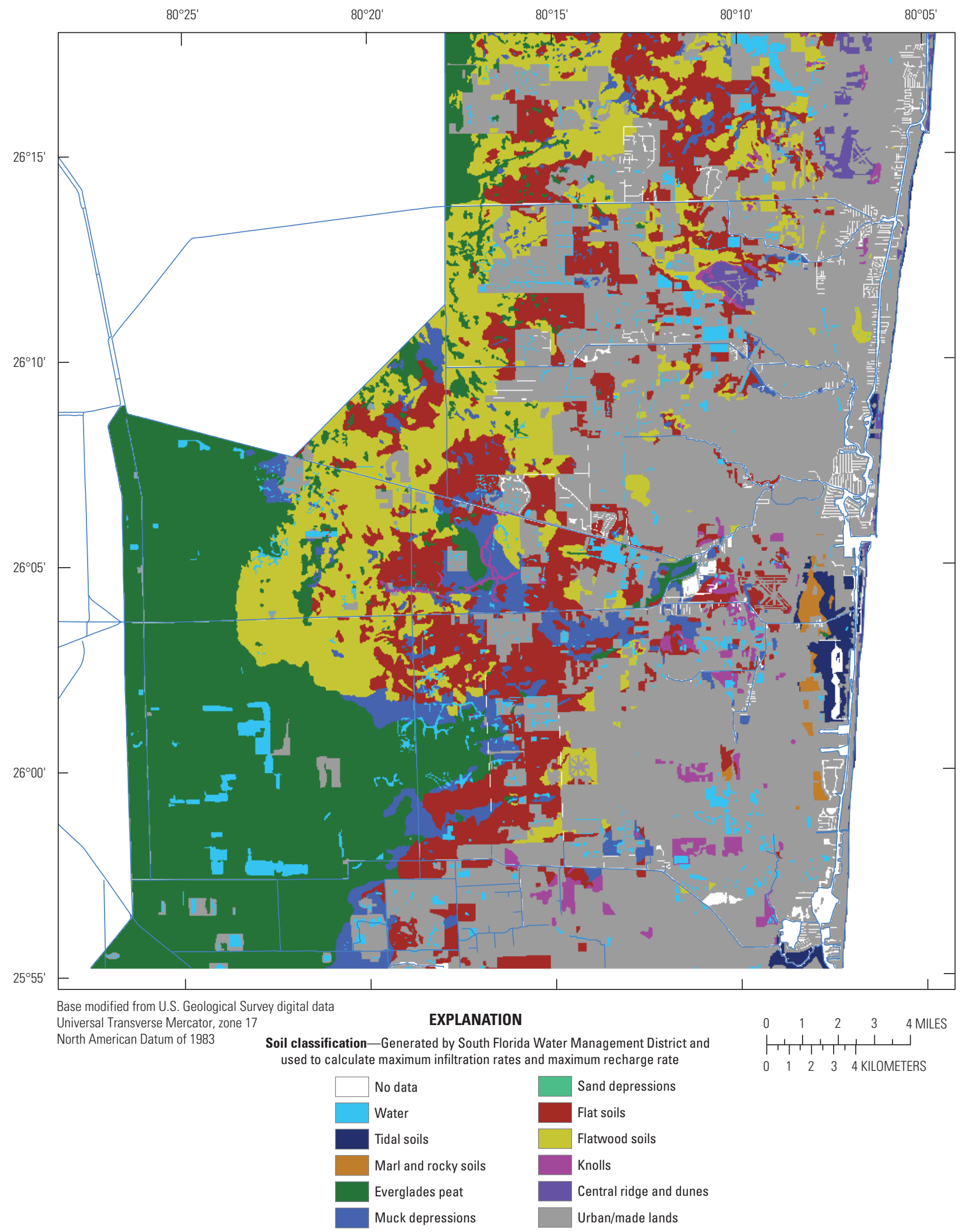

Figure 2.25. Soil classification coverage generated by the South Florida Water Management District and used to calculate maximum infiltration rates and maximum recharge rate. 
Table 2.4. Hydrological group codes used in soil classification completed by the South Florida Water Management District.

[in/h, inch per hour; \%, percent; >, greater than; <, less than; $\leq$, less than or equal to]

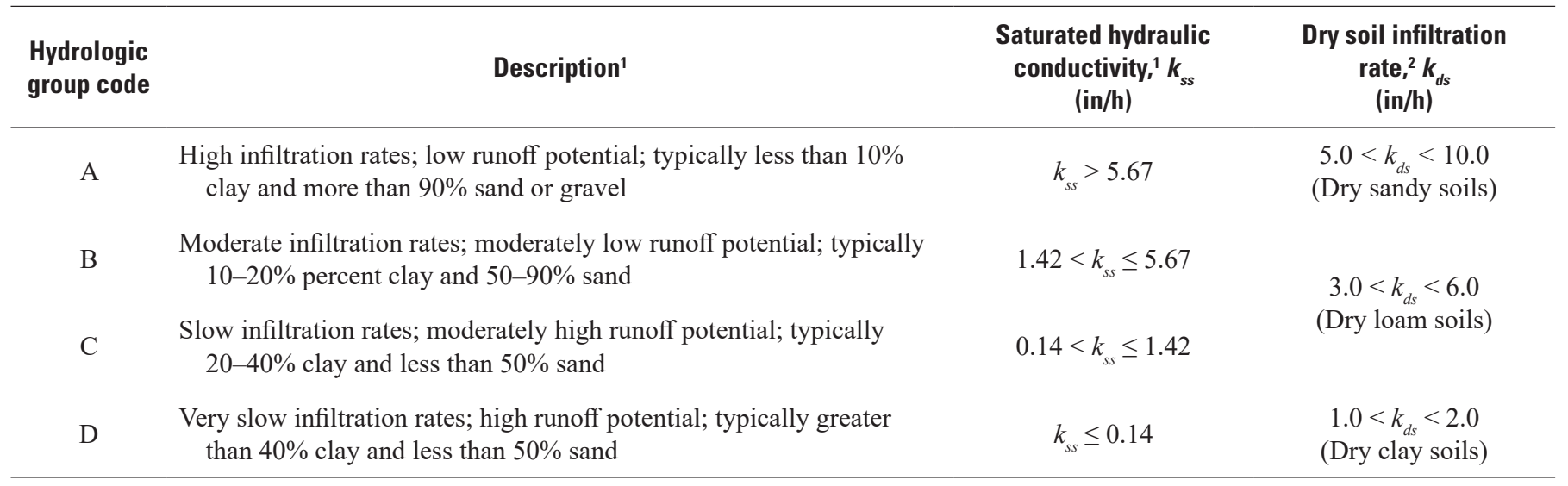

${ }^{1}$ Descriptions and typical $k_{s s}$ values from "National Engineering Handbook" (U.S. Department of Agriculture, 2007).

${ }^{2}$ Typical $k_{d s}$ values for soil types from "Urban Stormwater Hydrology: A Guide to Engineering Calculations" (Akan, 1993).

Table 2.5. Natural Soils Landscape Position classifications and associated hydrological group codes found within Broward County soil sample sites and corresponding infiltration and conductivity values used in model parameter development (based on Zahina and others, 2001).

[NSLP, Natural Soils Landscape Position; Hydrological group code descriptions can be found in table 2.4; in/h, inch per hour]

\begin{tabular}{|c|c|c|c|}
\hline NSLP description & $\begin{array}{l}\text { Associated hydrological } \\
\text { group code }\end{array}$ & $\begin{array}{l}\text { Saturated hydraulic } \\
\text { conductivity used } \\
\text { for model, } k_{s s} \\
\text { (in/h) }\end{array}$ & $\begin{array}{l}\text { Dry soil infiltration rate } \\
\text { used for model, } \boldsymbol{k}_{d s} \\
\text { (in/h) }\end{array}$ \\
\hline Water & Not applicable & 10.0 & 10.0 \\
\hline Tidal soils & $\mathrm{D}$ & 0.14 & 2.0 \\
\hline Everglades peat & $\mathrm{D}$ & 0.14 & 2.0 \\
\hline Muck depressions & $\mathrm{D}$ & 0.14 & 2.0 \\
\hline Sand depressions & $\mathrm{D}$ & 0.14 & 2.0 \\
\hline Central ridge and dunes & A & 6.0 & 7.5 \\
\hline Urban or made lands & Not applicable & 5.0 & 6.5 \\
\hline
\end{tabular}




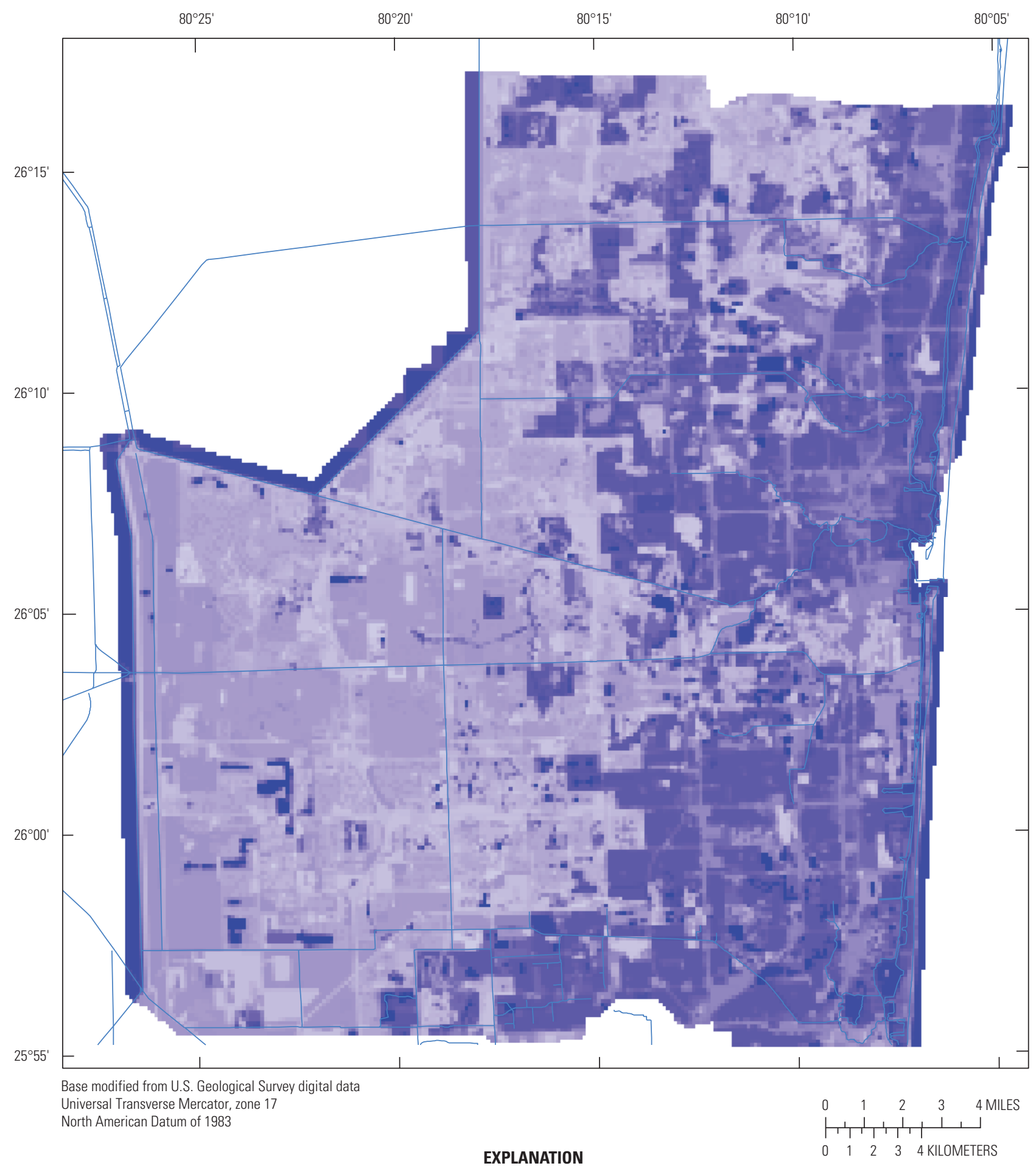

Calculated maximum infiltration rates, in feet per day-Used by the Urban Runoff process

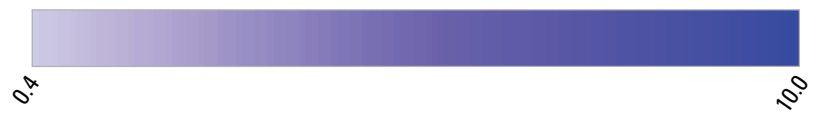

Figure 2.26. Calculated maximum infiltration rates used by the Urban Runoff process within the county-scale model area. 


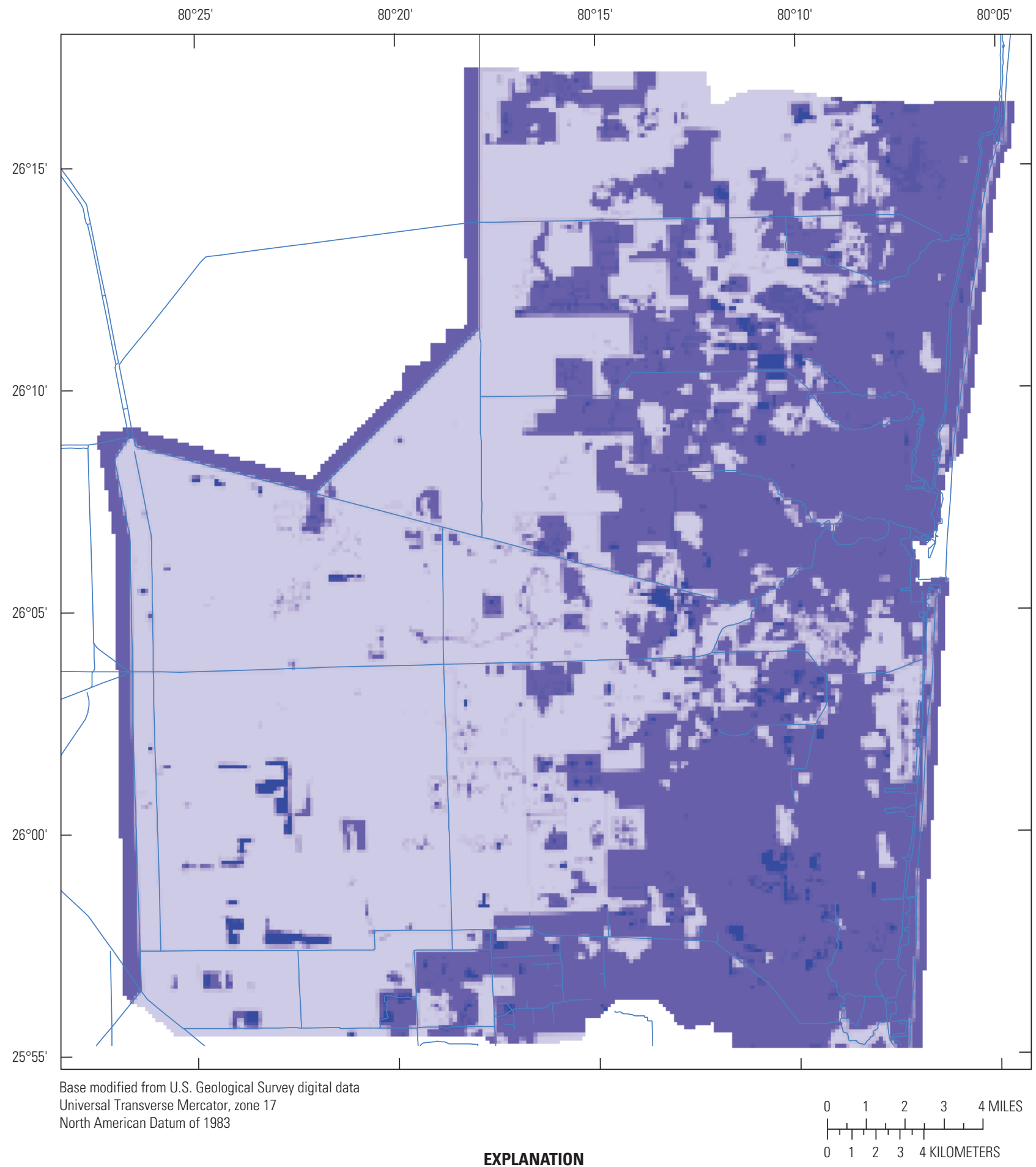

Calculated maximum recharge rates, in feet per day-Used by the Urban Runoff process

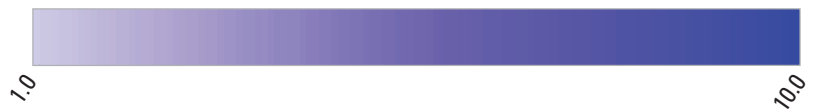

Figure 2.27. Calculated maximum recharge rates used by the Urban Runoff process within the county-scale model area. 
Table 2.6. Manning's $n$ values based on land-use types used to calculate composite Manning's $n$ values for the county-scale model (South Florida Water Management District, 2005).

[ft, foot]

\begin{tabular}{lcc}
\hline Land-use description & Manning's $\boldsymbol{n}$ & $\begin{array}{c}\text { Detention } \\
\text { depth } \\
\text { (ft) }\end{array}$ \\
\hline Urban/low density & 0.20 & 0.60 \\
Urban/medium density & 0.14 & 0.55 \\
Urban/high density & 0.08 & 0.50 \\
Agriculture & 0.23 & $0.10-0.50$ \\
Wetland & & 0.10 \\
Forest/forested wetlands ${ }^{1}$ & $0.75-1.25$ & 0.10 \\
Water & 0.35 & 0.10 \\
Forests/forested uplands & 0.01 & 0.10 \\
\hline
\end{tabular}

\footnotetext{
${ }^{1}$ Manning's $n$ value actually calculated by using $N=n(h)^{b}$, where $h=$ depth, $b=-0.77$; values shown are for $h=1 \mathrm{ft}$.
}

Table 2.7. Estimated Manning's $n$ and detention depth for land-use categories found in Broward County, Florida.

$[\mathrm{ft}$, foot $]$

\begin{tabular}{lcc}
\hline \multicolumn{1}{c}{ Land-use category } & Manning's $\boldsymbol{n}$ & $\begin{array}{c}\text { Detention } \\
\text { depth } \\
\text { (ft) }\end{array}$ \\
\hline Low-density residential & 0.20 & 0.60 \\
Medium-density residential & 0.14 & 0.55 \\
High-density residential & 0.14 & 0.55 \\
Commercial & 0.08 & 0.50 \\
Industrial & 0.14 & 0.55 \\
Institutional & 0.14 & 0.55 \\
Recreational & 0.20 & 0.60 \\
Open land (urban) & 0.14 & 0.55 \\
Cropland/pasture, tree crops, & 0.23 & 0.30 \\
$\quad$ nurseries, farms & & \\
Open land (rural) & 0.23 & 0.30 \\
Upland forested & 0.85 & 0.10 \\
Upland nonforested & 0.23 & 0.30 \\
Water & 0.03 & 0.10 \\
Wetland & 1.00 & 0.10 \\
Disturbed land & 0.20 & 0.60 \\
Transportation & 0.08 & 0.10 \\
Communications/utilities & 0.08 & 0.10 \\
\hline
\end{tabular}

\section{Specific Yield and Specific Storage}

The specific yield of the top layer, which was specified as convertible, was calculated from the values used in the county-scale model by using bilinear interpolation. The calculated specific yield used in layer 1 of the local-scale model varied from 0.16 to 0.4 , with a mean value of 0.29 (fig. 2.34). The specific yield is the volume of water released from storage by the unconfined aquifer per unit area per groundwater head change and is therefore unitless. The specific storage for all layers was set to a constant value of $1.00 \times 10^{-5} \mathrm{ft}^{-1}$. The specific storage is the volume of water released from a confined aquifer per volume of aquifer per unit head change and therefore has units of per foot.

\section{Groundwater Pumpage}

Groundwater pumpage within the local-scale model was represented by using the MODFLOW WEL package. The locations and pumping rates were taken from the saltwater-intrusion model (Hughes and others, 2016). The layer from which the water was removed was determined the same way as in the county-scale model. The pumping rates from within the local-scale model from the historical period were used for all future scenarios and varied between $8.3 \mathrm{Mgal} / \mathrm{d}$ and 17.9 Mgal/d, with an average value of $11.9 \mathrm{Mgal} / \mathrm{d}$ (fig. 2.35).

\section{Canal Representation Using the Surface-Water Routing Process}

The canal network within the local-scale model area was represented by using the SWR1 process. Primary and most secondary drainage features were included, as well as some tertiary drainage features (fig. 3 in main body of report). Locations and parameters for the primary and secondary features were the same as those used in the county-scale model. The locations and parameters used for the tertiary drainage features were taken from a dataset produced by Florida Atlantic University (Hindle, 1992). All canals within the local-scale model were represented as active level-pool reach groups. The parts of the canal network east of the coastal control structures were divided into 10 reach groups connected by using basic weir structure types. The lengths of these groups varied from $255 \mathrm{ft}$ to $27,971 \mathrm{ft}$, with a mean length of 13,901 ft. The weir crest elevations were specified as the canal bottom elevations, and weir widths were specified as canal widths. The equivalent weir flow coefficients for these structures were calculated by using the Manning's equation with average canal depth, Manning's friction, and connected reach group lengths. The equivalent weir flow coefficients varied from 0.23 to 0.46 , with a mean of 0.31 .

\section{Represented Canal Structures}

Three structures from the county-scale model were also represented in the local-scale model: $\mathrm{G}-54, \mathrm{~S}-13$, and S-13a (fig. 2.16). The $\mathrm{G}-54$ and $\mathrm{S}-13$ structures were represented as 


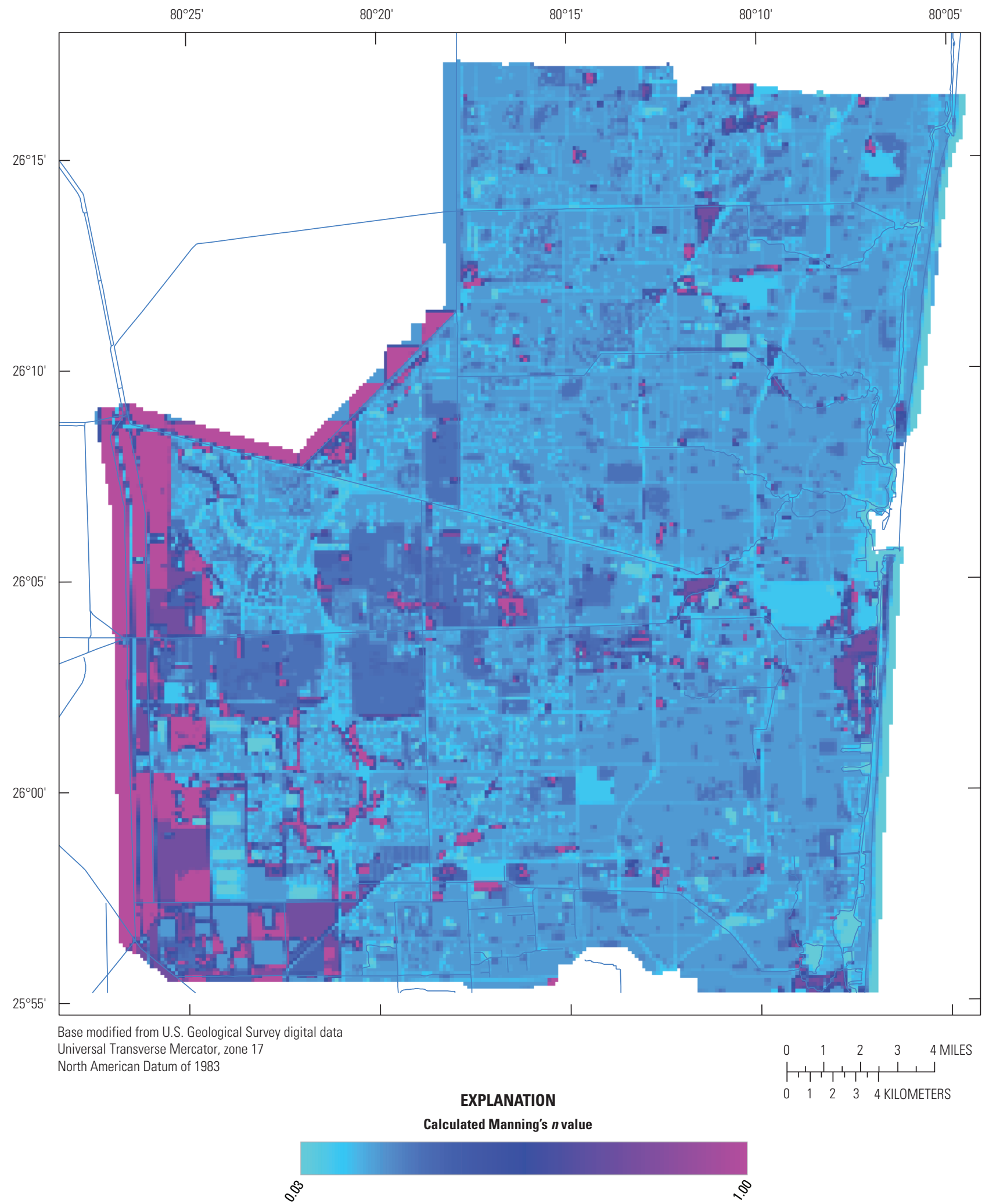

Figure 2.28. Calculated Manning's $n$ for the county-scale model area. 


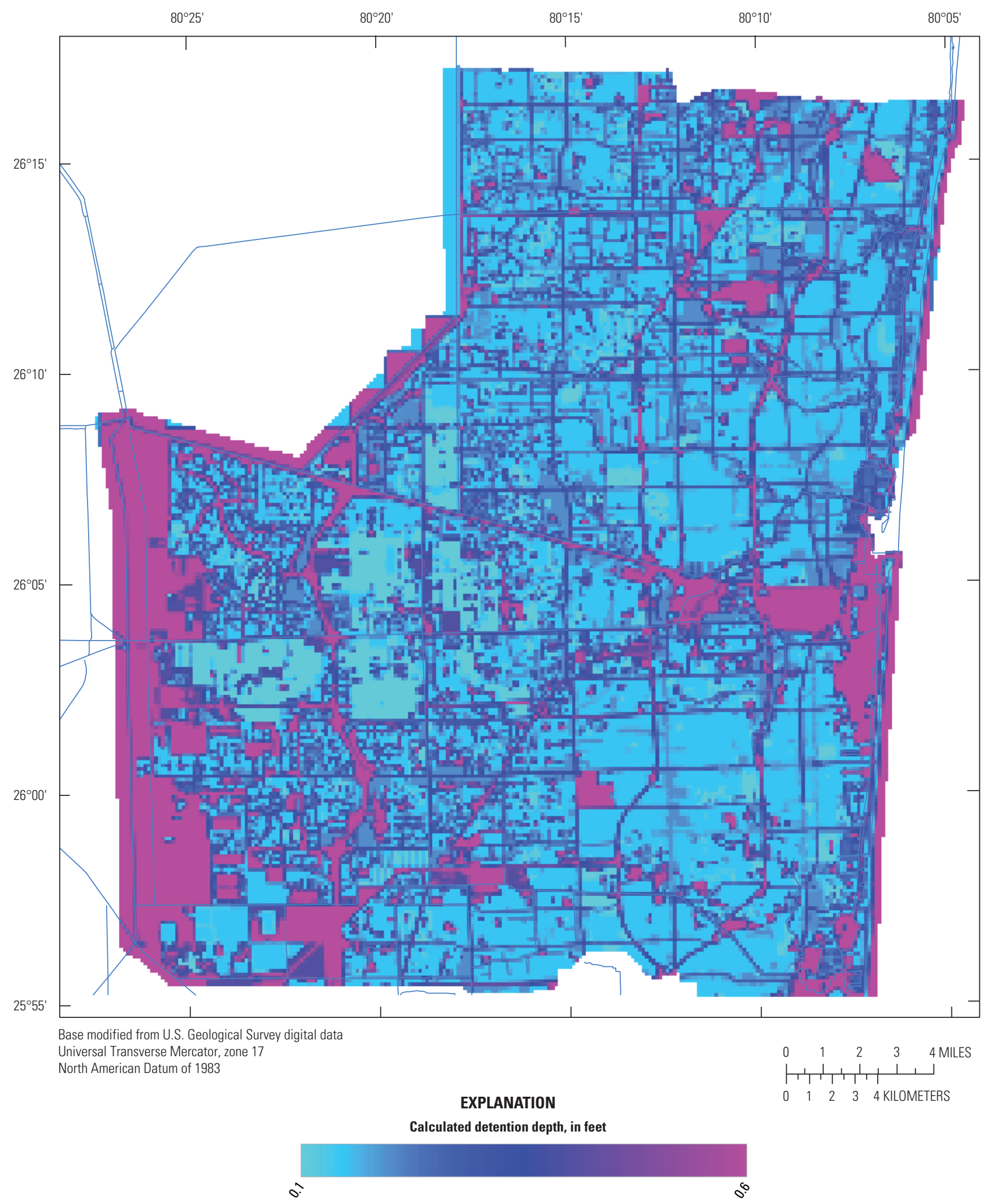

Figure 2.29. Calculated detention depth for the county-scale model area. 

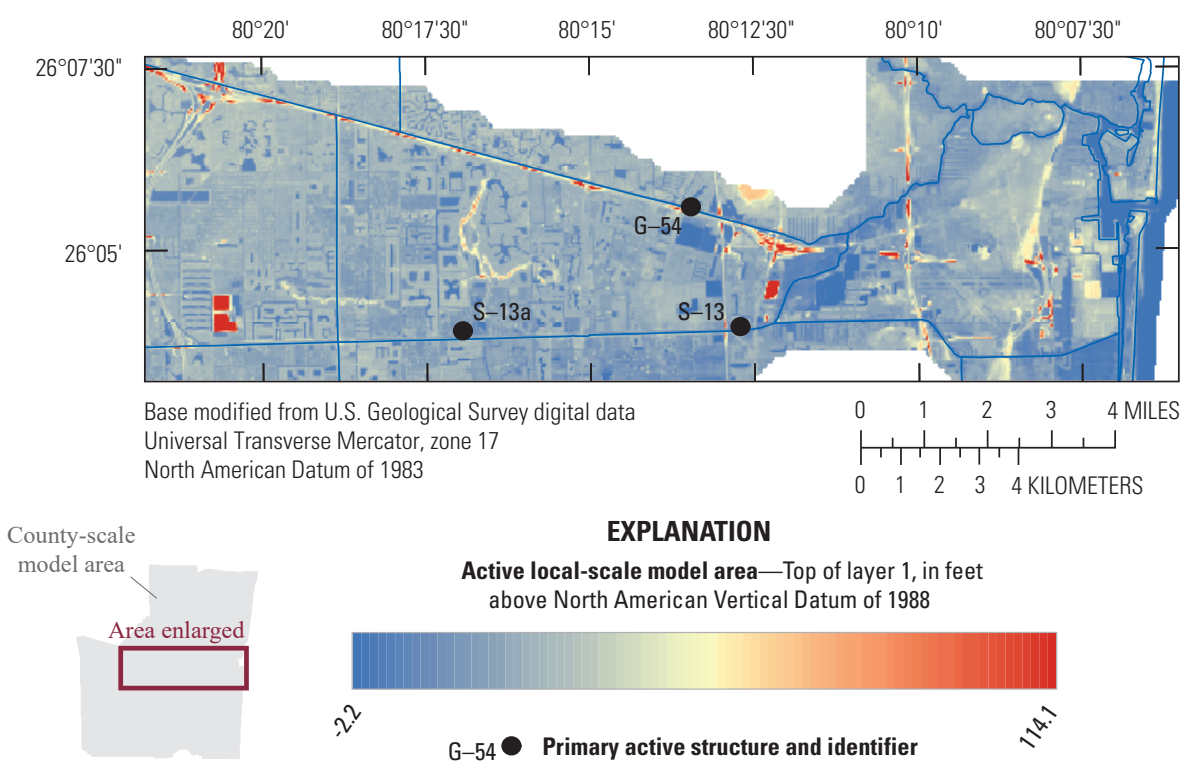

EXPLANATION

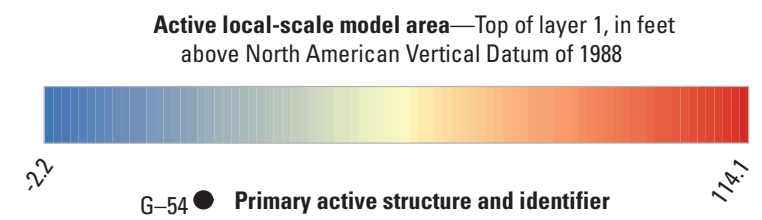

Figure 2.30. Local-scale model top of layer 1.

gated spillways with the same structure parameters as those used in the county-scale model (table 2.2). The S-13 pump station was represented with the same stage-discharge curve as that used in the county-scale model. The S-13a structure was represented as a fixed crest weir with the same parameters as was used in the county-scale model (table 2.1).

\section{Linkage to County-Scale Model and Tidal Boundaries}

The local-scale model used head-dependent boundaries created from the simulated county-scale model (figs. 2 and 3 in main body of report). Simulated daily groundwater levels for each scenario were used as GHBs along the local-scale model's perimeter. The GHBs representing tidal areas (fig. 3 in main body of report) used the same daily tidal input as used in the county-scale model.

Specified flows into the western ends of the SWR1 canal network were generated by county-scale model output and represented the flows into each of the canals that enter the local-scale model area (fig. 3 in main body of report). The tidal boundary into the SWR1 canal network was represented by an hourly updated specified stage at the easternmost end of each of the two primary coastal canals in the local-scale model. The hourly tidal data were the same data used to create the daily tidal stage used as GHB input for the local- and county-scale models.

\section{Representation of Conceptualized Surface-Water Processes Using the Urban Runoff Process}

As in the county-scale model, the remaining hydrologic processes were represented by using the URO process. These processes include precipitation, evapotranspiration, infiltration, and recharge.

\section{Precipitation and Evapotranspiration}

The same daily precipitation and potential ET volumes that were specified for the county-scale model were also used in the local-scale model. The precipitation and ET volume for each grid cell was specified as the volume from the corresponding $10-\mathrm{km}$ by $10-\mathrm{km}$ regional climate model cell (fig. 2.20).

\section{Infiltration and Groundwater Recharge}

The same methodology used to calculate the maximum infiltration and recharge rate in the county-scale model was used for the local-scale model. These parameters were recalculated by using the same land-use and soil coverages (figs. 2.24 and 2.25). The calculated values of maximum infiltration rate varied from $0.4 \mathrm{ft} / \mathrm{d}$ to $10.0 \mathrm{ft} / \mathrm{d}$ (fig. 2.36A). The calculated values of maximum recharge rate varied from $0.1 \mathrm{ft} / \mathrm{d}$ to $10.0 \mathrm{ft} / \mathrm{d}$ (fig. $2.36 B$ ). 
A. Layer 1 bottom elevations

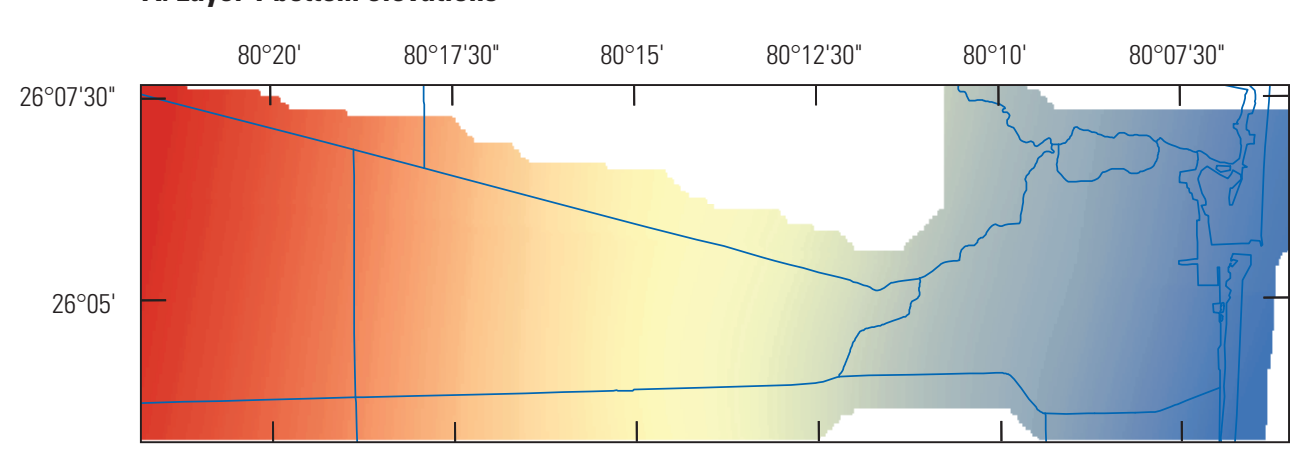

EXPLANATION

Elevation, in feet above North American Vertical Datum of 1988 (NAVD 88)

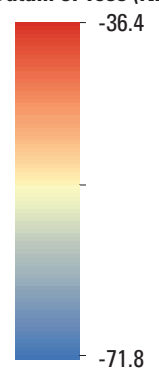

\section{B. Layer 2 bottom elevations}

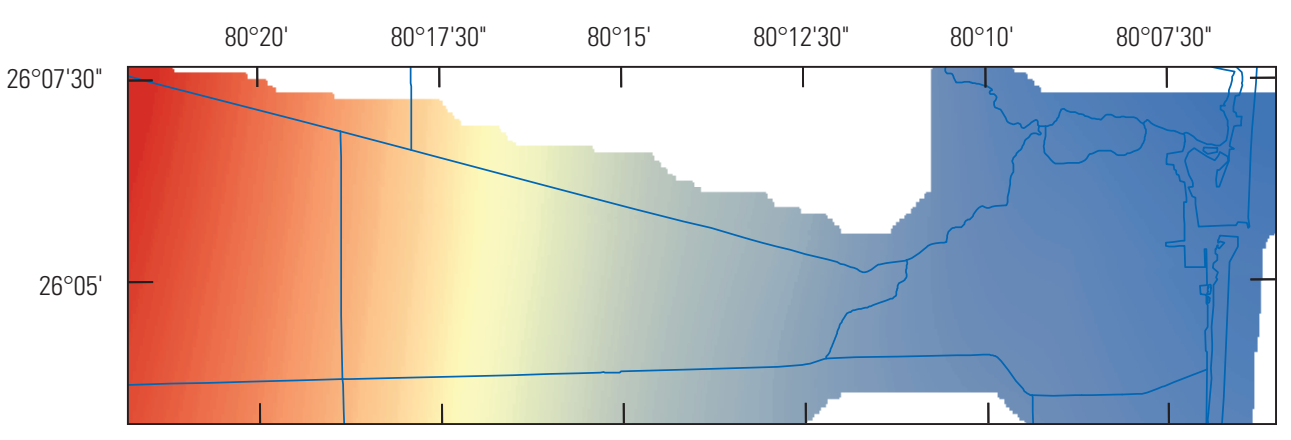

\section{EXPLANATION}

Elevation, in feet above NAVD 88

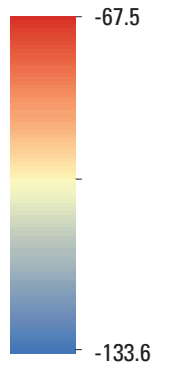

\section{Layer 3 bottom elevations}

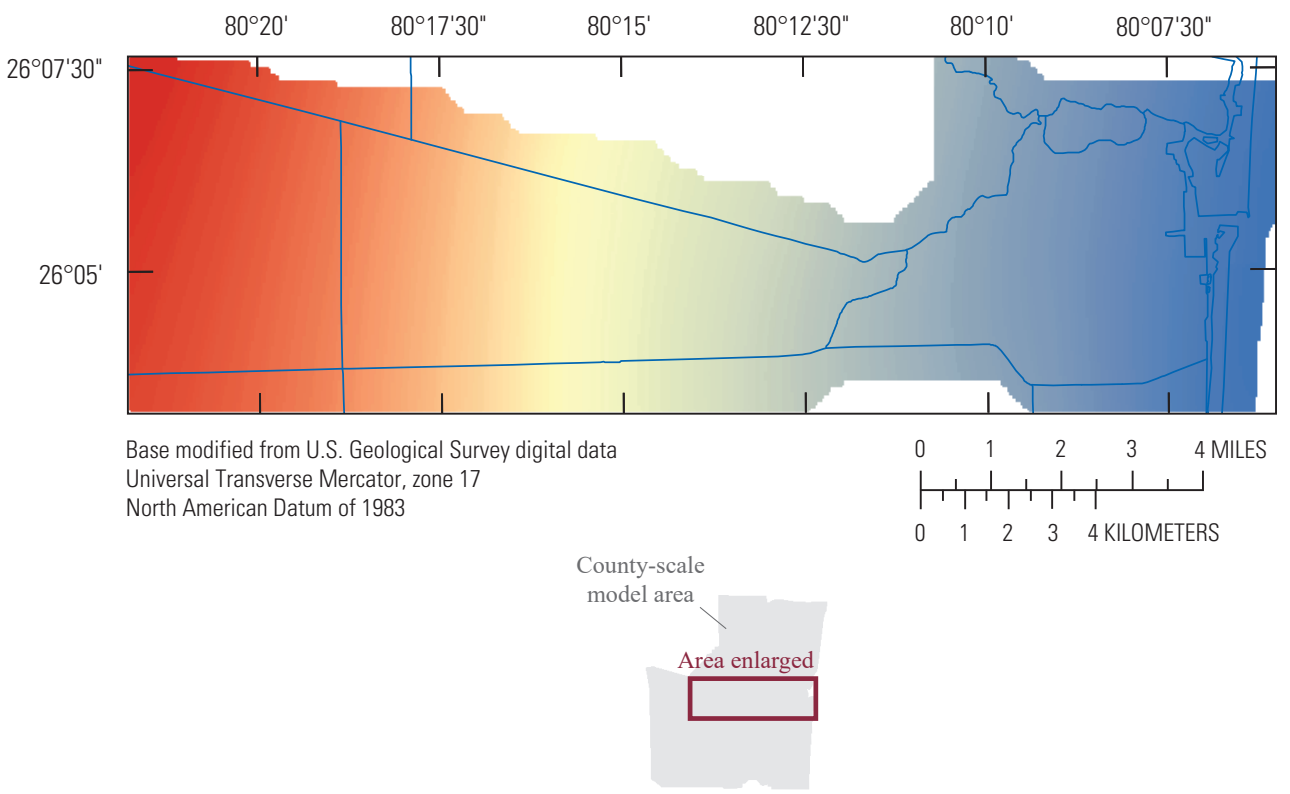

EXPLANATION

Elevation, in feet above NAVD 88

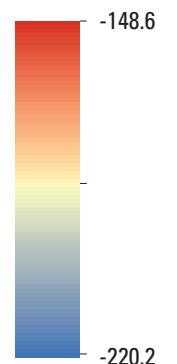

Figure 2.31. Local-scale model $A$, bottom of layer $1 ; B$, bottom of layer 2; and $C$, bottom of layer 3 . 
A. Layer 1 horizontal hydraulic conductivity

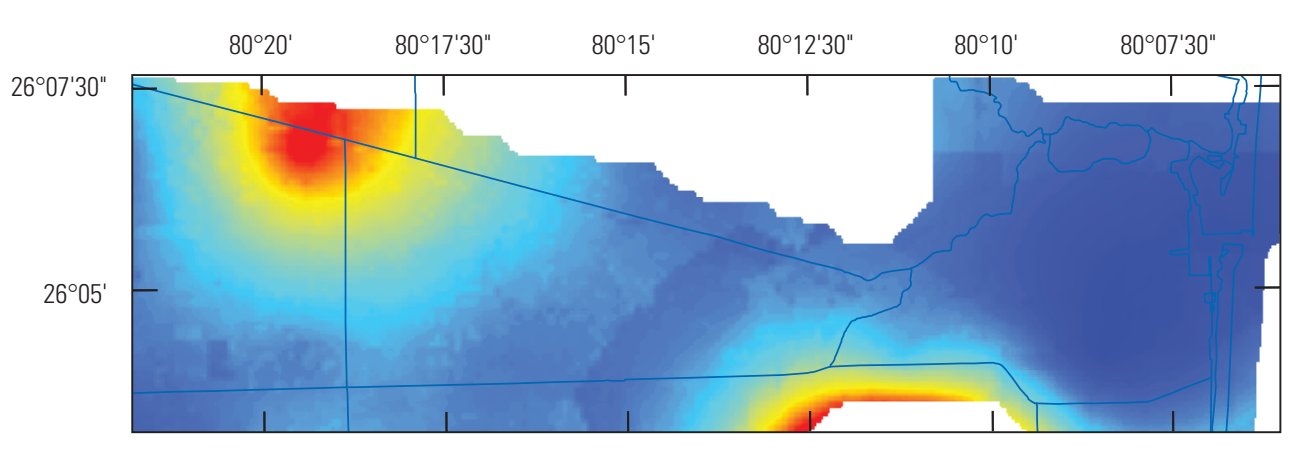

\section{EXPLANATION}

Horizontal hydraulic conductivity, in feet per day (ft/d)

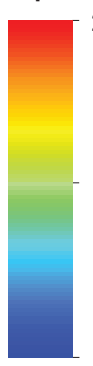

$2,439.2$

411.8

\section{B. Layer 2 horizontal hydraulic conductivity}

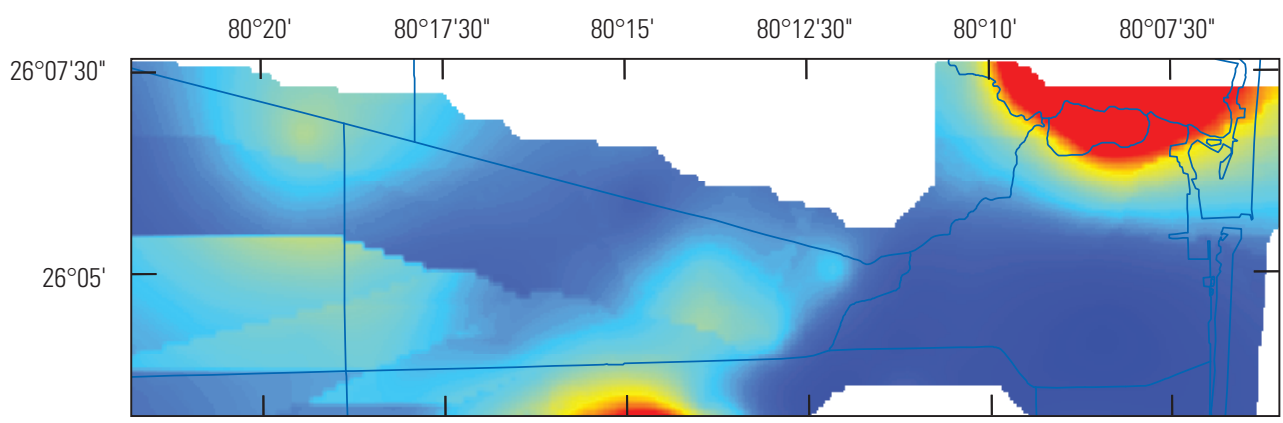

\section{EXPLANATION}

Horizontal hydraulic conductivity, in $\mathrm{ft} / \mathrm{d}$

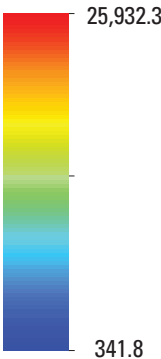

341.8

\section{Layer 3 horizontal hydraulic conductivity}

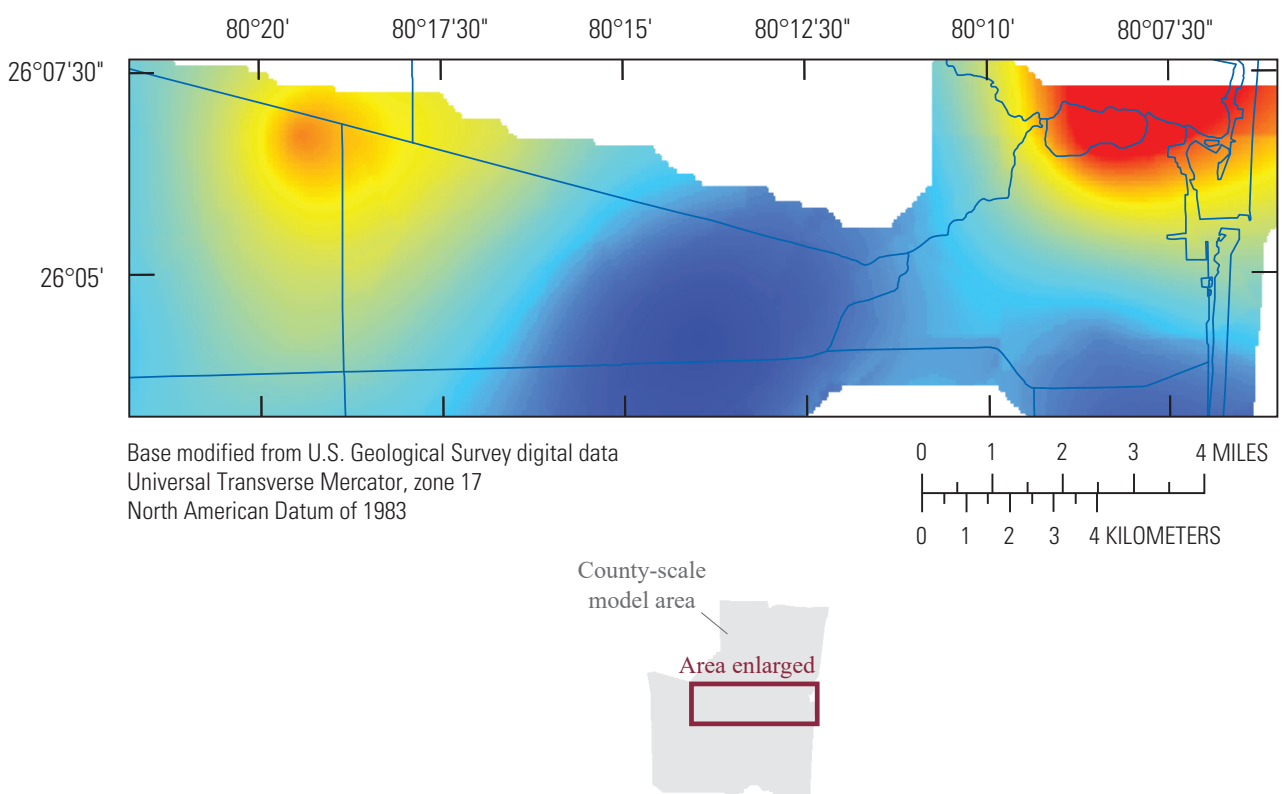

EXPLANATION

Horizontal hydraulic conductivity, in $\mathrm{ft} / \mathrm{d}$

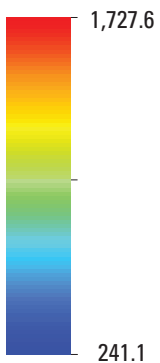

Figure 2.32. Horizontal hydraulic conductivity used for $A$, layer $1 ; B$, layer 2 ; and $C$, layer 3 in the local-scale model. 
A. Layer 1 vertical hydraulic conductivity

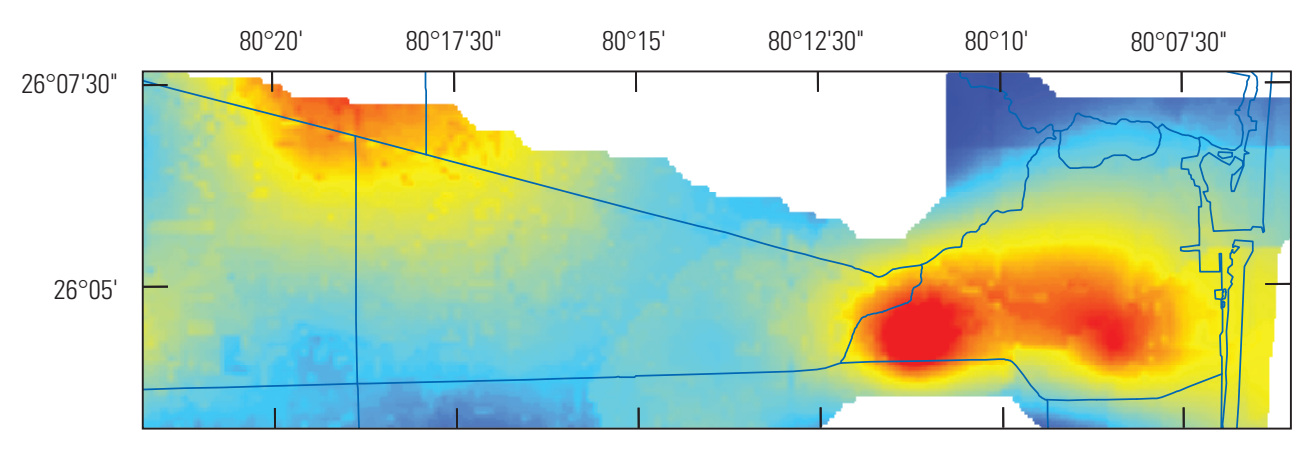

EXPLANATION

Vertical hydraulic conductivity, in feet per day ( $\mathrm{ft} / \mathrm{d})$

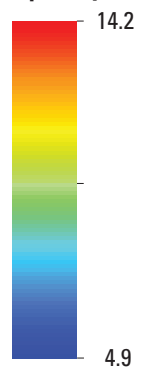

B. Layer 2 vertical hydraulic conductivity

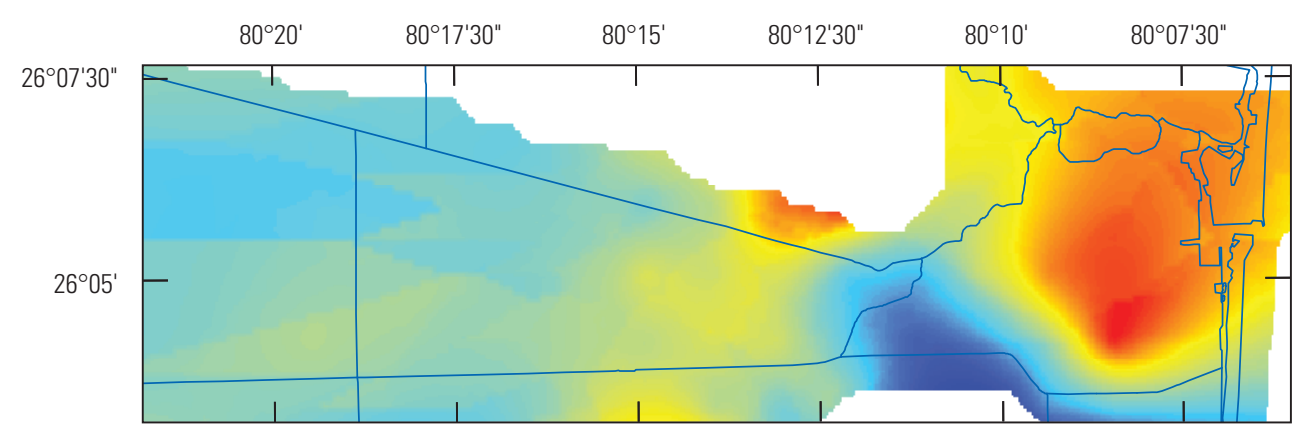

EXPLANATION

Vertical hydraulic conductivity, in $\mathrm{ft} / \mathrm{d}$

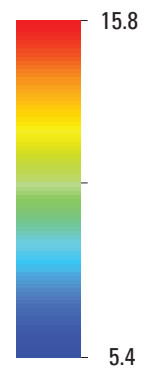

C. Layer 3 vertical hydraulic conductivity
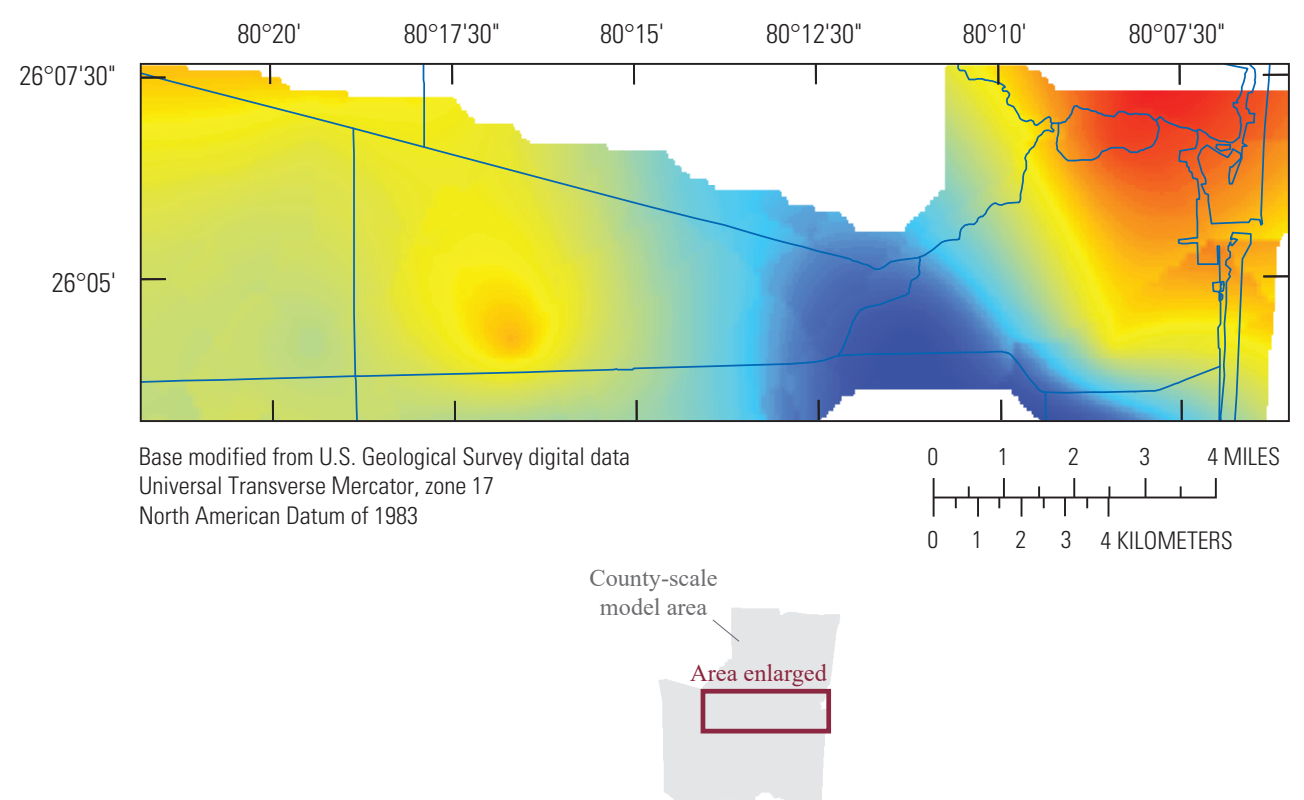

Figure 2.33. Vertical hydraulic conductivity used for $A$, layer 1; $B$, layer 2; and $C$, layer 3 in the local-scale model. 


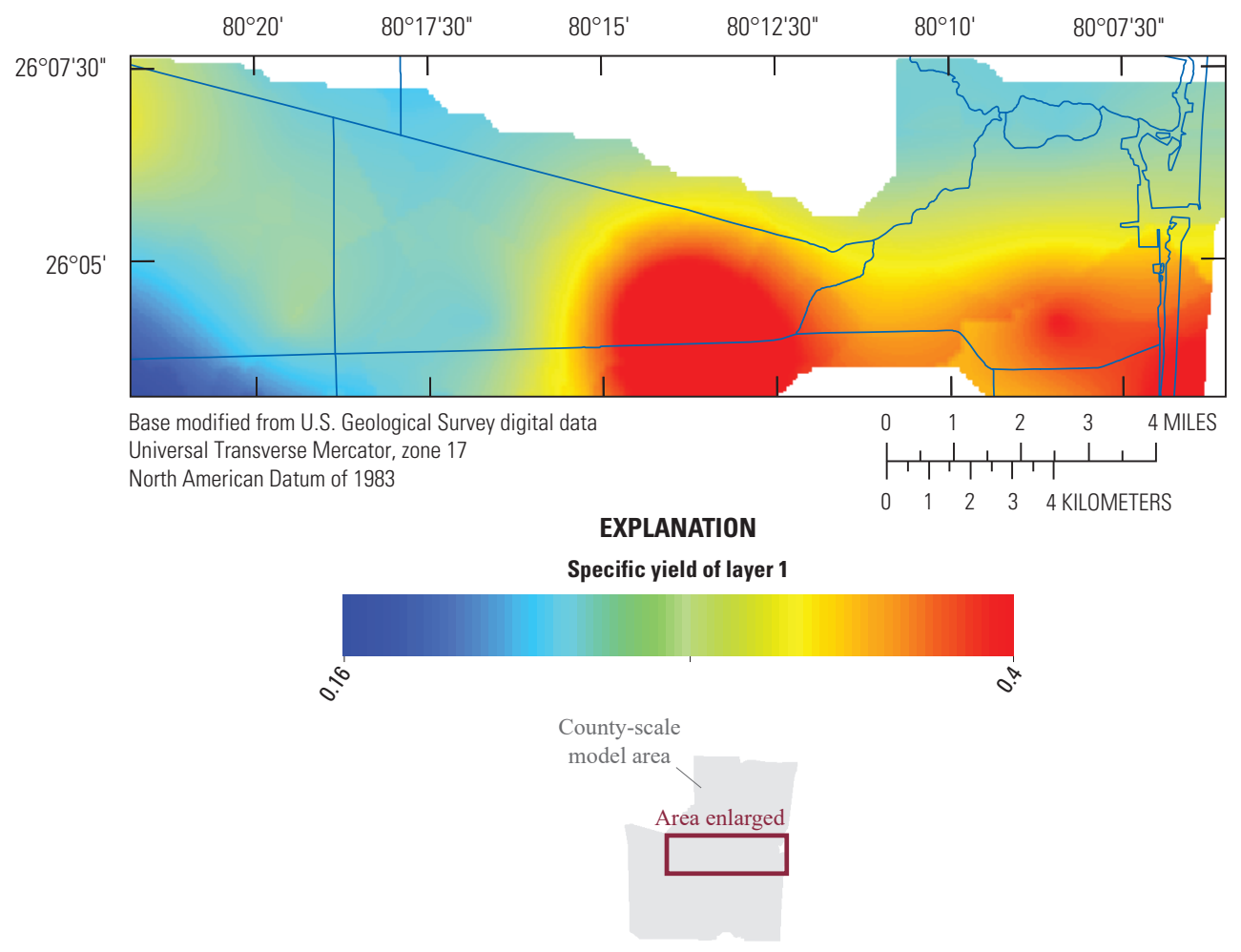

Figure 2.34. Specific yield of layer 1 used in the local-scale model.

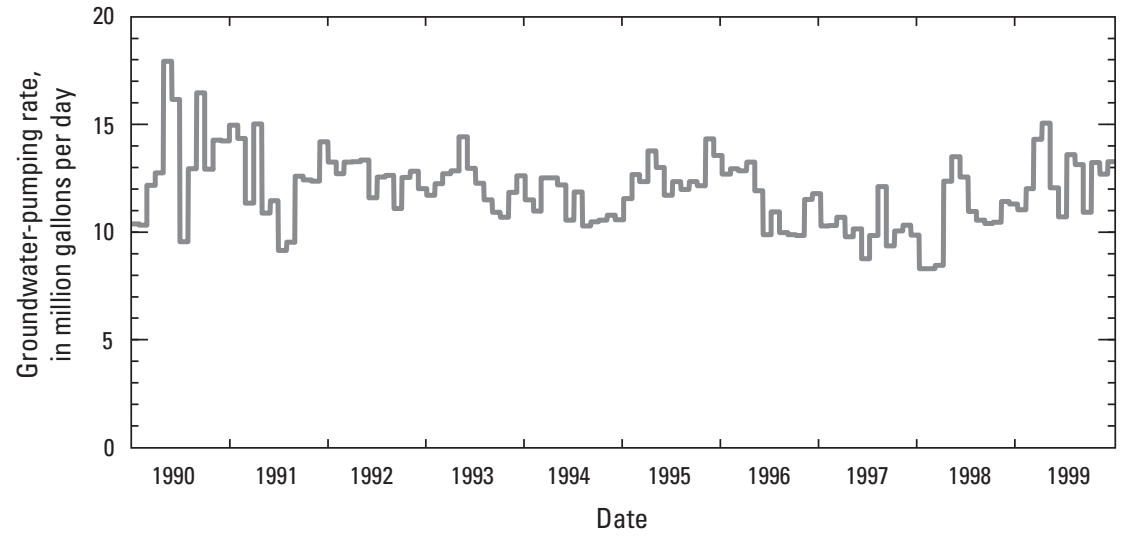

Figure 2.35. Total groundwater-pumping rate in the local-scale model area for all simulations. 
A. Maximum infiltration rate

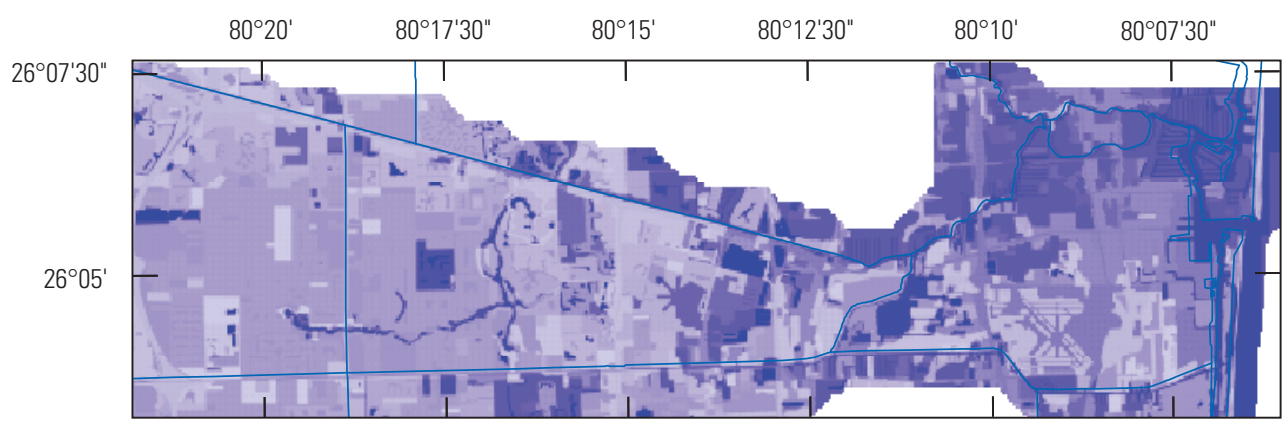

\section{B. Maximum recharge rate}

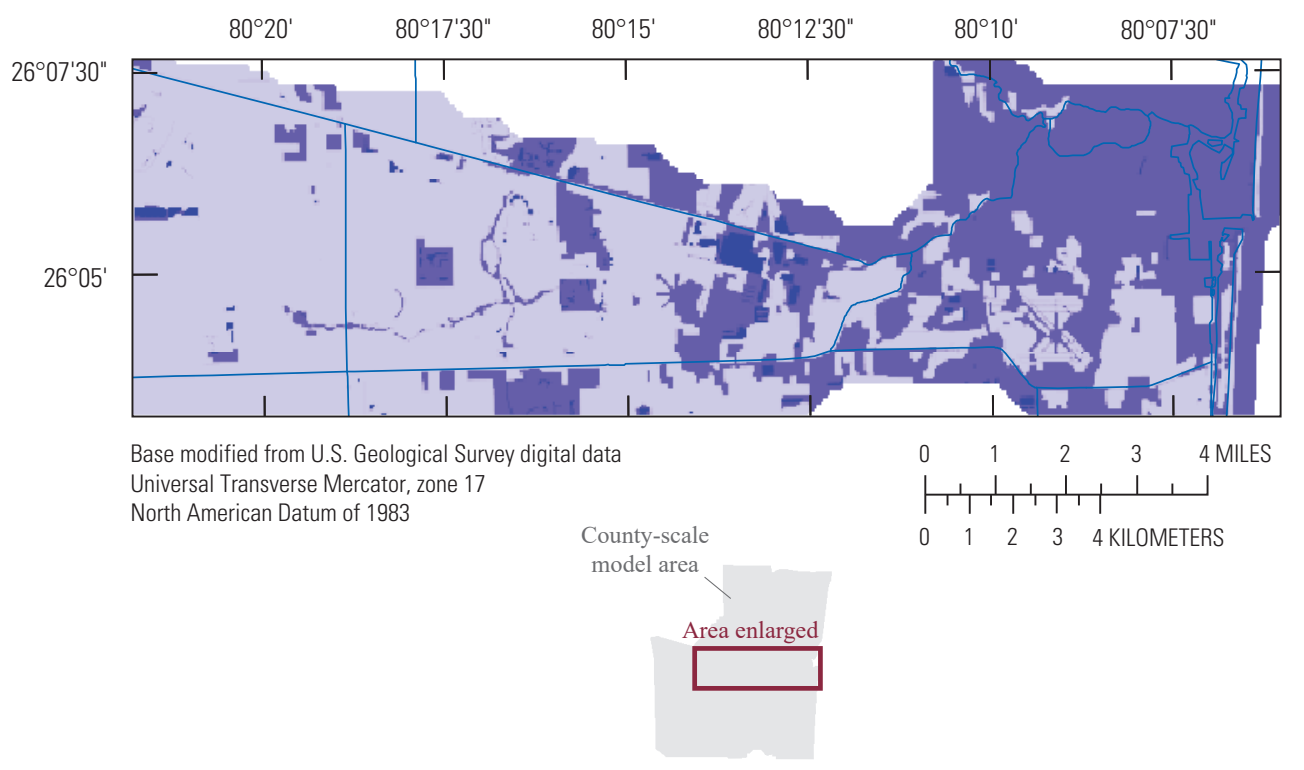

EXPLANATION

Maximum infiltration rate,

in feet per day

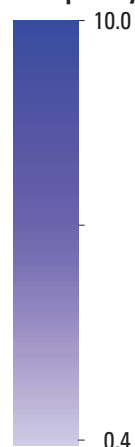

EXPLANATION

Maximum recharge rate, in feet per day

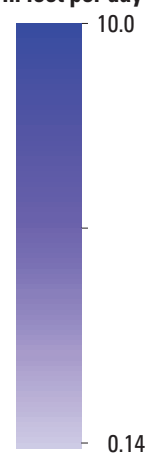

Figure 2.36. Maximum infiltration rate, $A$, and maximum recharge rate, $B$, for the local-scale model. 


\section{References Cited}

Akan, O.A., 1993, Urban stormwater hydrology-A guide to engineering calculations: Boca Raton, Fla., CRC Press, LLC.

Cappiella, K., and Brown, K., 2001, Impervious cover and land use in the Chesapeake Bay watershed: Ellicott City, Md., Center for Watershed Protection, $51 \mathrm{p}$.

Decker, J.D., 2018, MODFLOW 2005 data sets for the simulation of potential increased inundation in flood-prone regions of Southeast Florida in response to climate and sea-level changes in Broward County, Florida, 2060-69: U.S. Geological Survey data release, https://dx.doi.org/10.5066/P9E6INWZ.

Decker, J.D., and Hughes, J.D., 2013, Urban runoff (URO) process for MODFLOW 2005-Simulation of sub-grid scale urban hydrologic processes in Broward County, Florida, in MODFLOW and More 2013 - Translating Science into Practice Proceedings: Golden, Colo., Colorado School of Mines, Integrated Groundwater Modeling Center, p. 216-221.

Dougherty, M., Dymond, R.L., Goetz, S.J., Jantz, C.A., and Goulet, N., 2004, Evaluation of impervious surface estimates in a rapidly urbanizing watershed: Photogrammetric Engineering and Remote Sensing, v. 70, no. 11, p. 1275-1284.

Hindle, T. and Restrepo, J., 1999, Broward County hydrographic survey report: Boca Raton, Fla., Florida Atlantic University Department of Geography \& Geology.

Hughes, J.D., Sifuentes, D.F., and White, J.T., 2016, Simulated effects of alterations to the hydrologic system on the distribution of salinity in the Biscayne aquifer in Broward County, Florida: U.S. Geological Survey Scientific Investigations Report 2016-5022.
Islam, N., and Dunn, D., 2006, Recalibration and consolidation of integrated surface water and groundwater models for Broward County: Broward County Environmental Protection Department, Water Resources Division, 40 p.

Kluitenberg, E., 1994, Wayne County Rouge Program office memorandum - Determination of impervious area and directly connected impervious area: Rouge Program Office.

South Florida Water Management District, 2005, Documentation of the South Florida Water Management Model Version 5.5: West Palm Beach, Fla., South Florida Water Management District Final Peer Review Report.

South Florida Water Management District (SFWMD), 2016, Structure books: West Palm Beach, Fla., accessed May 19, 2016, at ftp://ftp.sfwmd.gov/pub/hehmke/AsBuilts/ Other\%20Reports/OCC\%20Structure\%20Book.pdf.

U.S. Army Corps of Engineers (USACE), 2011, Water resources policies and authorities incorporating sea-level change considerations in civil works programs: Washington, D.C., Department of Army, U.S. Army Corps of Engineers, EC 1165-2-211.

U.S. Department of Agriculture (USDA), Natural Resource Conservation Service, 1986, Urban hydrology for small watersheds: Washington D.C., U.S. Department of Agriculture Technical Release 55.

Wood, A.W., Maurer, E.P., Kumar, A., and Letternmaier, D.P., 2002, Long-range experimental hydrologic forecasting for the eastern United States: Journal of Geophysical Research, v. 107, p. 4429. [Also available online at https://doi.org/10.1029/2001JD000659.]

Zahina, J., Liudahl, K., Liebermann, T., Saari, K., Krenz, J., and Mullen, V., 2001, Soil classification databaseCategorization of county soil survey data within the SFWMD including natural soils landscape positions: West Palm Beach, Fla., South Florida Water Management District, Water Supply Planning Department, Technical Publication WS-06. 


\section{Appendix 3. Sensitivity Testing of Numerical Models}

A sensitivity analysis was completed to evaluate the influence of the primary parameters on the behavior of the system. Of particular interest are the uncertain parameter influences on groundwater levels, active canal stages, and active structure flows. The canal leakances, general head boundary (GHB) conductivities, horizontal and vertical hydraulic conductivities, and the maximum infiltration and recharge rates were varied, and the results are presented in this appendix.

\section{Horizontal and Vertical Hydraulic Conductivity}

The original horizontal and vertical conductivity fields varied from 186 feet per day (ft/d) to $32,000 \mathrm{ft} / \mathrm{d}$ and from $1.1 \mathrm{ft} / \mathrm{d}$ to $39.5 \mathrm{ft} / \mathrm{d}$, respectively. The mean and standard deviation of the log transformed hydraulic conductivity values were calculated, and three uniform parameter fields for each conductivity, horizontal and vertical, were created for the analysis: (1) the log-transformed mean conductivity, (2) one standard deviation greater than the log-transformed mean conductivity, and (3) one standard deviation less than the logtransformed mean conductivity. These transformations resulted in values of $1,057 \mathrm{ft} / \mathrm{d}, 2,376 \mathrm{ft} / \mathrm{d}$, and $470 \mathrm{ft} / \mathrm{d}$ for the horizontal conductivity and values of $6.9 \mathrm{ft} / \mathrm{d}, 10.1 \mathrm{ft} / \mathrm{d}$, and $4.7 \mathrm{ft} / \mathrm{d}$ for the vertical conductivity. The model's sensitivities to these parameters were tested independently from one another.

The effect of horizontal hydraulic conductivities on groundwater levels varied spatially, with maximum differences of $2.850 \mathrm{feet}(\mathrm{ft}$ ), $-2.010 \mathrm{ft}$, and $5.357 \mathrm{ft}$ occurring at G-2395 for uniform conductivity values of $1,057 \mathrm{ft} / \mathrm{d}, 470 \mathrm{ft} / \mathrm{d}$, and $2,376 \mathrm{ft} / \mathrm{d}$, respectively (table 3.1). In general, the groundwater wells nearest to the GHBs exhibited the least sensitivity to horizontal conductivities, with mean differences of $-0.044 \mathrm{ft}$, $-0.001 \mathrm{ft}$, and $-0.071 \mathrm{ft}$ for conductivity values of $1,057 \mathrm{ft} / \mathrm{d}$, $470 \mathrm{ft} / \mathrm{d}$, and 2,376 ft/d, respectively. The interior wells were the most sensitive, with mean differences of $0.615 \mathrm{ft},-0.231 \mathrm{ft}$, and $1.006 \mathrm{ft}$ for conductivity values of $1,057 \mathrm{ft} / \mathrm{d}, 470 \mathrm{ft} / \mathrm{d}$, and 2,376 ft/d, respectively. Structure flow rates generally decreased with lower conductivity values and increased with higher values, except for structure S-33 (table 3.1). The largest differences in flow rates occurred at $\mathrm{S}-9$, with a decrease of 22 percent for a conductivity of $470 \mathrm{ft} / \mathrm{d}$ and an increase of 24 percent for a conductivity of $2,370 \mathrm{ft} / \mathrm{d}$.

The sensitivity analysis of the vertical conductivity revealed a general insensitivity in most locations. The average difference in mean groundwater levels for the comparison wells was $0.037 \mathrm{ft}, 0.055 \mathrm{ft}$, and $0.025 \mathrm{ft}$ for vertical conductivity values of $6.9 \mathrm{ft} / \mathrm{d}, 4.7 \mathrm{ft} / \mathrm{d}$, and $10.1 \mathrm{ft} / \mathrm{d}$, respectively. The location with the highest sensitivity was $\mathrm{G}-2395$, which is near a pumping-well location. The mean flow rate from the primary structures was also generally insensitive to changes in vertical conductivity, with a maximum difference of 3.3 percent at structure $\mathrm{S}-33$ for a vertical conductivity of $4.7 \mathrm{ft} / \mathrm{d}$ (table 3.2).

\section{Conductance at Western Groundwater Boundary}

The western groundwater boundaries were generated by using the Everglades Depth Estimation Network (EDEN) data. Although the EDEN data tended to overestimate the local groundwater levels near the boundaries of the model, they provided good estimates for the interior parts of the Water Conservation Areas. The original boundary conductance $(C)$ values associated with these boundaries were calculated by using the calibrated horizontal conductivity from the saltwater-intrusion model discussed in appendix 2 and the main body of the report, the vertical cell thickness and width to calculate the flow area, and an assumed 10-cell width (0.95 mile) as the horizontal connection distance:

$$
C=\frac{H_{k} A}{\Delta X},
$$

where

$$
\begin{array}{cl}
H_{k} \quad \begin{array}{c}
\text { is the horizontal hydraulic conductivity of the } \\
\text { connection; }
\end{array} \\
A \quad \begin{array}{r}
\text { is the flow area perpendicular to the } \\
\text { connection; and }
\end{array} \\
\Delta X \quad \begin{array}{l}
\text { is the horizontal distance parallel to the flow } \\
\text { connection. }
\end{array}
\end{array}
$$

Two sensitivity simulations were run by using conductance values of 25 percent and 200 percent of the originally calculated values, which represented horizontal-flow connection distances of 40 -cell widths (3.78 miles) and 5-cell widths ( 0.47 mile), respectively. The resulting groundwater levels at the 15 groundwater observation sites showed general insensitivity to the boundary conductance, which produced a maximum mean difference in the average groundwater level of $-0.042 \mathrm{ft}$ at G-2034 for the 25-percent conductance simulation (table 3.3). The average groundwater-level difference for the 15 observation sites was $-0.006 \mathrm{ft}$ and $0.004 \mathrm{ft}$ for the 25 - and 200-percent conductance simulations, respectively. This insensitivity can be explained through examination of the change in flow rate through the primary structures. Structures G-54 and S-9 exhibited the largest percentage differences, with decreases of 15.6 percent and 29.3 percent, respectively, in average structure flow for the 25 -percent conductance 
Table 3.1. Sensitivity results for variations of horizontal conductivities using uniform parameter fields within the county-scale model. [ft, foot; $H_{k}$, horizontal hydraulic conductivity; $\mathrm{ft} / \mathrm{d}$, foot per day; $\mathrm{ft}^{3} / \mathrm{s}$, cubic foot per second; $\%$, percent]

\begin{tabular}{|c|c|c|c|c|}
\hline Station name & $\begin{array}{c}\text { Mean groundwater level } \\
\text { (ft) } \\
\text { Original } \boldsymbol{H}_{k} \text { field }\end{array}$ & $\begin{array}{c}\text { Mean difference }(\mathrm{ft}) \\
H_{k}=1,057 \mathrm{ft} / \mathrm{d}\end{array}$ & $\begin{array}{c}\text { Mean difference (ft) } \\
\qquad H_{k}=470 \mathrm{ft} / \mathrm{d}\end{array}$ & $\begin{array}{c}\text { Mean difference }(\mathrm{ft}) \\
H_{k}=2,370 \mathrm{ft} / \mathrm{d}\end{array}$ \\
\hline $\mathrm{G}-2031$ & 6.628 & -0.037 & 0.051 & -0.125 \\
\hline $\mathrm{G}-1316$ & 6.580 & -0.146 & -0.145 & -0.192 \\
\hline $\mathrm{G}-853$ & 0.781 & 0.227 & -0.075 & 0.434 \\
\hline $\mathrm{G}-2033$ & 5.136 & -0.147 & 0.087 & -0.352 \\
\hline G-2395 & -3.952 & 2.850 & -2.010 & 5.357 \\
\hline $\mathrm{G}-1220$ & 0.184 & 0.579 & 1.377 & 0.103 \\
\hline G-617 & 2.232 & 0.025 & 0.022 & 0.037 \\
\hline $\mathrm{G}-1221$ & 1.066 & 0.071 & 0.335 & -0.078 \\
\hline $\mathrm{G}-561$ & 0.310 & 0.118 & 0.993 & -0.359 \\
\hline G-2034 & 1.894 & -0.022 & -0.088 & 0.075 \\
\hline $\mathrm{G}-1225$ & 1.307 & 0.357 & 0.499 & 0.144 \\
\hline F-291 & -0.422 & 0.520 & 1.114 & 0.225 \\
\hline $\mathrm{G}-970$ & 1.366 & -0.038 & -0.079 & 0.009 \\
\hline $\mathrm{G}-3571$ & 1.399 & -0.058 & 0.165 & -0.201 \\
\hline G-2294 & -0.598 & -0.106 & -0.136 & -0.073 \\
\hline Structure & $\begin{array}{c}\text { Mean flow }\left(\mathrm{ft}^{3} / \mathrm{s}\right) \\
\text { Original } H_{k} \text { field }\end{array}$ & $\begin{array}{l}\% \text { Difference } \\
H_{k}=1,057 \mathrm{ft} / \mathrm{d}\end{array}$ & $\begin{array}{c}\% \text { Difference } \\
H_{k}=470 \mathrm{ft} / \mathrm{d}\end{array}$ & $\begin{array}{l}\% \text { Difference } \\
H_{k}=2,370 \mathrm{ft} / \mathrm{d}\end{array}$ \\
\hline G-54 & 312.5 & $1.3 \%$ & $-7.1 \%$ & $9.7 \%$ \\
\hline S-13 (spillway) & 91.6 & $-6.2 \%$ & $-22 \%$ & $15.3 \%$ \\
\hline $\mathrm{S}-33$ & 19.9 & $11.5 \%$ & $7.3 \%$ & $3.1 \%$ \\
\hline S-9 & 258.9 & $-0.8 \%$ & $-22.4 \%$ & $24.0 \%$ \\
\hline
\end{tabular}

Table 3.2. Sensitivity results for variations of vertical conductivities using uniform parameter fields for county-scale model.

[ft, foot; $V_{k}$, vertical hydraulic conductivity; $\mathrm{ft} / \mathrm{d}$, foot per day; $\mathrm{ft}^{3} / \mathrm{s}$, cubic foot per second; $\%$, percent]

\begin{tabular}{|c|c|c|c|c|}
\hline Station name & $\begin{array}{l}\text { Mean stage }(\mathrm{ft}) \\
\text { Original } V_{k} \text { field }\end{array}$ & $\begin{array}{l}\text { Mean difference }(\mathrm{ft}) \\
\text { Uniform } V_{k}=6.9 \mathrm{ft} / \mathrm{d}\end{array}$ & $\begin{array}{l}\text { Mean difference }(\mathrm{ft}) \\
\text { Uniform } V_{k}=4.7 \mathrm{ft} / \mathrm{d}\end{array}$ & $\begin{array}{l}\text { Mean difference }(\mathrm{ft}) \\
\text { Uniform } V_{k}=10.1 \mathrm{ft} / \mathrm{d}\end{array}$ \\
\hline G-2031 & 6.628 & 0.000 & 0.006 & -0.006 \\
\hline G-1316 & 6.580 & -0.015 & -0.038 & 0.008 \\
\hline $\mathrm{G}-853$ & 0.781 & 0.011 & 0.028 & 0.001 \\
\hline G-2033 & 5.136 & 0.001 & 0.028 & -0.022 \\
\hline G-2395 & -3.952 & 0.403 & 0.264 & 0.585 \\
\hline $\mathrm{G}-1220$ & 0.184 & 0.028 & 0.155 & -0.079 \\
\hline G-617 & 2.231 & -0.003 & -0.001 & -0.005 \\
\hline G-1221 & 1.066 & 0.044 & 0.116 & -0.022 \\
\hline G-561 & 0.310 & 0.076 & 0.191 & -0.019 \\
\hline G-2034 & 1.894 & -0.003 & 0.015 & -0.020 \\
\hline G-1225 & 1.307 & -0.003 & 0.014 & 0.017 \\
\hline $\mathrm{F}-291$ & -0.422 & 0.000 & 0.002 & -0.002 \\
\hline G-970 & 1.366 & 0.002 & 0.004 & 0.003 \\
\hline G-3571 & 1.399 & 0.005 & 0.046 & -0.033 \\
\hline G-2294 & -0.598 & 0.002 & 0.000 & 0.002 \\
\hline Structure & $\begin{array}{l}\text { Mean flow }\left(\mathrm{ft}^{3} / \mathrm{s}\right) \\
\text { Original } V_{k} \text { field }\end{array}$ & $\begin{array}{c}\% \text { Difference } \\
\text { Uniform } V_{k}=6.9 \mathrm{ft} / \mathrm{d}\end{array}$ & $\begin{array}{c}\% \text { Difference } \\
\text { Uniform } V_{k}=4.7 \mathrm{ft} / \mathrm{d}\end{array}$ & $\begin{array}{c}\% \text { Difference } \\
\text { Uniform } V_{k}=10.1 \mathrm{ft} / \mathrm{d}\end{array}$ \\
\hline G-54 & $312.5^{n}$ & $-0.2 \%$ & $-2.6 \%$ & $1.9 \%$ \\
\hline S-13 (spillway) & 91.6 & $-1.2 \%$ & $2.8 \%$ & $1.9 \%$ \\
\hline S-33 & 19.9 & $0.2 \%$ & $3.3 \%$ & $-1.0 \%$ \\
\hline S-9 & 258.9 & $-0.3 \%$ & $2.4 \%$ & $0.5 \%$ \\
\hline
\end{tabular}


Table 3.3. Sensitivity results for variations in conductance along western general head boundaries (GHBs) within county-scale model.

[ft, foot; \%, percent; $\mathrm{ft}^{3} / \mathrm{s}$, cubic foot per second]

\begin{tabular}{|c|c|c|c|}
\hline Station name & $\begin{array}{l}\text { Mean groundwater level (ft) } \\
\text { Original conductances }\end{array}$ & $\begin{array}{c}\text { Mean difference }(\mathrm{ft}) \\
25 \% \text { of original conductances }\end{array}$ & $\begin{array}{c}\text { Mean difference }(\mathrm{ft}) \\
200 \% \text { of original conductances }\end{array}$ \\
\hline G-2031 & 6.628 & 0.001 & 0.000 \\
\hline G-1316 & 6.580 & -0.002 & 0.001 \\
\hline G-853 & 0.781 & 0.001 & 0.000 \\
\hline G-2033 & 5.136 & -0.029 & 0.020 \\
\hline $\mathrm{G}-2395$ & -3.952 & 0.000 & 0.000 \\
\hline $\mathrm{G}-1220$ & 0.184 & 0.001 & 0.000 \\
\hline G-617 & 2.232 & -0.033 & 0.019 \\
\hline $\mathrm{G}-1221$ & 1.066 & 0.001 & -0.001 \\
\hline G-561 & 0.310 & 0.001 & 0.000 \\
\hline G-2034 & 1.894 & -0.042 & 0.022 \\
\hline $\mathrm{G}-1225$ & 1.307 & 0.000 & 0.000 \\
\hline F-291 & -0.422 & 0.000 & 0.000 \\
\hline G-970 & 1.366 & 0.005 & -0.003 \\
\hline G-3571 & 1.399 & 0.004 & -0.002 \\
\hline G-2294 & -0.598 & 0.000 & 0.000 \\
\hline Structure & $\begin{array}{c}\text { Mean flow }\left(\mathrm{ft}^{3} / \mathrm{s}\right) \\
\text { Original conductances }\end{array}$ & $\begin{array}{c}\% \text { Difference } \\
25 \% \text { of original conductances }\end{array}$ & $\begin{array}{c}\% \text { Difference } \\
200 \% \text { of original conductances }\end{array}$ \\
\hline G-54 & 312.5 & $-15.6 \%$ & $8.7 \%$ \\
\hline S-13 (spillway) & 91.6 & $-0.2 \%$ & $0.2 \%$ \\
\hline S-33 & 19.9 & $0.5 \%$ & $-0.8 \%$ \\
\hline S-9 & 258.9 & $-29.3 \%$ & $16.4 \%$ \\
\hline
\end{tabular}

simulation and increases of 8.7 percent and 16.4 percent, respectively, for the 200-percent conductance simulation. These results illustrate the canal system's ability to effectively control the groundwater elevations within their surrounding areas. Structures $\mathrm{S}-13$ and $\mathrm{S}-33$ showed little change in average flows with the values used at the boundaries for the sensitivity tests, but these structures were more distant from these boundaries and separated by additional inland structures, such as $\mathrm{S}-13 \mathrm{a}$ (fig. 1 in main body of report).

\section{Maximum Infiltration and Recharge Rates}

The spatially variable maximum infiltration rates within the model varied from 10 to $0.4 \mathrm{ft} / \mathrm{d}$, with an average value of $2.7 \mathrm{ft} / \mathrm{d}$ and a standard deviation of $1.7 \mathrm{ft} / \mathrm{d}$. The spatially variable maximum recharge rates varied from
$10 \mathrm{ft} / \mathrm{d}$ to $1 \mathrm{ft} / \mathrm{d}$, with an average value of $2.9 \mathrm{ft} / \mathrm{d}$ and a standard deviation of $2.0 \mathrm{ft} / \mathrm{d}$. Sensitivity simulations were run with uniform maximum infiltration and recharge fields by using average values and values one standard deviation higher and lower than the averages. These tests resulted in paired maximum infiltration and recharge rates of 2.7 and $2.9 \mathrm{ft} / \mathrm{d}$, 4.4 and $5.0 \mathrm{ft} / \mathrm{d}$, and 1.0 and $0.9 \mathrm{ft} / \mathrm{d}$ for the three sensitivity simulations. Groundwater levels at the 15 observation site locations were generally insensitive to these changes, with mean changes in groundwater levels of $0.003 \mathrm{ft},-0.013 \mathrm{ft}$, and $0.006 \mathrm{ft}$ for the average, lower, and higher infiltration and recharge values, respectively (table 3-4). The flow rates through the primary structures also did not substantially vary with changes in the maximum infiltration and recharge rates. The maximum change of -4.8 percent was seen at S-33 for the lower values tested. The remaining changes in flows were 1.5 percent or less (table 3.4). 
Table 3.4. Sensitivity results for variations in maximum infiltration, $K_{\text {inf }}$ and recharge, $K_{\text {rec }}$ rates for county-scale model.

[ft/d, foot per day; $\mathrm{ft}^{3} / \mathrm{s}$, cubic foot per second; \%, percent]

\begin{tabular}{|c|c|c|c|c|}
\hline Station name & $\begin{array}{c}\text { Mean stage (ft/d) } \\
\text { Original } K_{i n f} \text { and } K_{r e c} \text { fields }\end{array}$ & $\begin{array}{c}\text { Mean difference }(\mathrm{ft} / \mathrm{d}) \\
K_{\text {inf }}=2.70, K_{\text {rec }}=2.91\end{array}$ & $\begin{array}{c}\text { Mean difference }(\mathrm{ft} / \mathrm{d}) \\
K_{i n f}=1.02, K_{r e c}=0.87\end{array}$ & $\begin{array}{c}\text { Mean difference }(\mathrm{ft} / \mathrm{d}) \\
K_{\text {inf }}=4.37, K_{r e c}=4.95\end{array}$ \\
\hline G-2031 & 6.628 & 0.003 & -0.005 & 0.005 \\
\hline G-1316 & 6.580 & 0.005 & -0.007 & 0.009 \\
\hline $\mathrm{G}-853$ & 0.781 & -0.003 & -0.016 & 0.001 \\
\hline G-2033 & 5.136 & 0.006 & -0.006 & 0.009 \\
\hline G-2395 & -3.952 & 0.002 & -0.018 & 0.009 \\
\hline G-1221 & 1.066 & 0.004 & -0.013 & 0.009 \\
\hline G-561 & 0.310 & -0.005 & -0.030 & 0.003 \\
\hline G-2034 & 1.894 & 0.005 & -0.002 & 0.007 \\
\hline $\mathrm{G}-1225$ & 1.307 & -0.001 & -0.023 & 0.006 \\
\hline F-291 & -0.422 & -0.002 & -0.011 & 0.000 \\
\hline Structure & $\begin{array}{l}\text { Mean flow }\left(\mathrm{ft}^{3} / \mathrm{s}\right) \\
\text { Original } K_{i n f} \text { and } K_{r e c} \text { fields }\end{array}$ & $\begin{array}{c}\% \text { Difference } \\
K_{\text {inf }}=2.70, K_{r e c}=2.91\end{array}$ & $\begin{array}{c}\% \text { Difference } \\
K_{\text {inf }}=1.02, K_{\text {rec }}=0.87\end{array}$ & $\begin{array}{c}\% \text { Difference } \\
K_{\text {inf }}=4.37, K_{\text {rec }}=4.95\end{array}$ \\
\hline G-54 & 312.5 & $0.1 \%$ & $-0.9 \%$ & $0.5 \%$ \\
\hline S-13 (spillway) & 91.6 & $0.6 \%$ & $-1.1 \%$ & $1.2 \%$ \\
\hline $\mathrm{S}-33$ & 19.9 & $-0.7 \%$ & $-4.8 \%$ & $0.8 \%$ \\
\hline S-9 & 258.9 & $1.1 \%$ & $-0.3 \%$ & $1.5 \%$ \\
\hline
\end{tabular}

\section{Canal Leakance Coefficient}

The canal leakance coefficient values used in the model were derived from the saltwater-intrusion model (Hughes and others, 2016). The calibrated riverbed conductance for each reach was divided by the length and average wetted parameter from the historical scenario to obtain the leakance coefficient. The resulting leakance coefficient values varied from 0.17 day $^{-1}$ to 17.27 day $^{-1}$, with an average of 3.66 day $^{-1}$. Sensitivity simulations were run with coefficient values modified to 50 percent and 200 percent of the original values, resulting in averages of $1.83 \mathrm{day}^{-1}$ and $7.33 \mathrm{day}^{-1}$, respectively. The effect of these changes on the groundwater levels at the 15 observation sites were average changes of $0.064 \mathrm{ft}$ and $-0.042 \mathrm{ft}$ for the 50 - and 200-percent leakance coefficient values, respectively. The largest difference occurred at G-2395, which is near a well field, with a mean difference of $-0.463 \mathrm{ft}$ and $0.404 \mathrm{ft}$ for the 50- and 200-percent leakance coefficient values, respectively. In general, an increase in leakance coefficient led to decreased groundwater levels, whereas an increase in the leakance coefficient resulted in increased groundwater levels (table 3.5). Flow at primary structure S-13 was the most sensitive to canal leakance coefficient, with a decrease of 14.7 percent and an increase of 13.9 percent in flows for the 50- and 200-percent leakance coefficient values, respectively. Flow at structure G-54 was the least sensitive to canal leakance coefficient, with decreases of 0.1 percent and -1.7 percent for the 50 - and 200 -percent leakance coefficient values, respectively (table 3.5 ). 
Table 3.5. Sensitivity results for variations in canal leakance coefficient, GLK within county-scale model.

[ft, foot; \%, percent; $\mathrm{ft}^{3} / \mathrm{s}$, cubic foot per second]

\begin{tabular}{|c|c|c|c|}
\hline Station name & $\begin{array}{c}\text { Mean groundwater level (ft) } \\
\text { Original leakances }\end{array}$ & $\begin{array}{c}\text { Mean difference }(\mathrm{ft}) \\
\mathbf{5 0 \%} \text { of original leakances }\end{array}$ & $\begin{array}{c}\text { Mean difference (ft) } \\
200 \% \text { of original leakances }\end{array}$ \\
\hline G-2031 & 6.628 & 0.055 & -0.034 \\
\hline G-1316 & 6.580 & 0.224 & -0.272 \\
\hline G-853 & 0.781 & -0.025 & 0.021 \\
\hline G-2033 & 5.137 & 0.079 & -0.018 \\
\hline G-2395 & -3.952 & -0.463 & 0.404 \\
\hline $\mathrm{G}-1220$ & 0.184 & 0.104 & -0.057 \\
\hline G-617 & 2.232 & 0.293 & -0.223 \\
\hline $\mathrm{G}-1221$ & 1.066 & 0.208 & -0.157 \\
\hline G-561 & 0.310 & 0.047 & -0.027 \\
\hline G-2034 & 1.894 & 0.117 & -0.063 \\
\hline G-1225 & 1.307 & 0.018 & 0.001 \\
\hline F-291 & -0.422 & 0.027 & -0.018 \\
\hline G-970 & 1.366 & 0.090 & -0.067 \\
\hline G-3571 & 1.399 & 0.171 & -0.117 \\
\hline G-2294 & -0.598 & 0.009 & -0.004 \\
\hline Structure & $\begin{array}{c}\text { Mean flow (ft3 } / \mathbf{s}) \\
\text { Original leakances }\end{array}$ & $\begin{array}{c}\% \text { Difference } \\
\mathbf{5 0 \%} \text { of original leakances }\end{array}$ & $\begin{array}{c}\% \text { Difference } \\
200 \% \text { of original leakances }\end{array}$ \\
\hline G-54 & 312.5 & $-0.1 \%$ & $-1.7 \%$ \\
\hline S-13 (spillway) & 91.6 & $-14.7 \%$ & $13.9 \%$ \\
\hline S-33 & 19.9 & $-6.2 \%$ & $2.9 \%$ \\
\hline S-9 & 258.9 & $-7.8 \%$ & $6.8 \%$ \\
\hline
\end{tabular}

\section{Conductance of General Head Boundary Adjacent to North New River Canal}

A separate simulation demonstrated the sensitivity of the structure flow at G-54 to the GHB adjacent and parallel to the westernmost part of the North New River Canal.

Although the EDEN data used for the boundary levels were higher than reasonably expected, they represented a good estimation of water-level depth farther within the Water Conservation Area. As a result, the conductance $(C)$ of the part of the GHB adjacent to the North New River Canal was reduced to represent a distance of 40-cell widths (3.78 miles) between the boundary and the connected cell. As with the previously described sensitivity simulation, this test resulted in conductance values that were 25 percent of the original values. The result was a decrease of 80.2 cubic feet per second $\left(\mathrm{ft}^{3} / \mathrm{s}\right)$, which reduced the mean difference from $114.0 \mathrm{ft}^{3} / \mathrm{s}$ to $35.2 \mathrm{ft}^{3} / \mathrm{s}$. This finding indicates that further refinements to the representation of the western boundaries could lead to enhanced model results.

\section{Reference Cited}

Hughes, J.D., Sifuentes, D.F., and White, J.T., 2016, Simulated effects of alterations to the hydrologic system on the distribution of salinity in the Biscayne aquifer in Broward County, Florida: U.S. Geological Survey Scientific Investigations Report 2016-5022. 
For more information about this publication, contact

Director, Caribbean-Florida Water Science Center

U.S. Geological Survey

4446 Pet Lane, Suite 108

Lutz, FL 33559

(813) 498-5000

For additional information visit

https://www2.usgs.gov/water/caribbeanflorida/index.html

Publishing support provided by

Lafayette Publishing Service Center 
